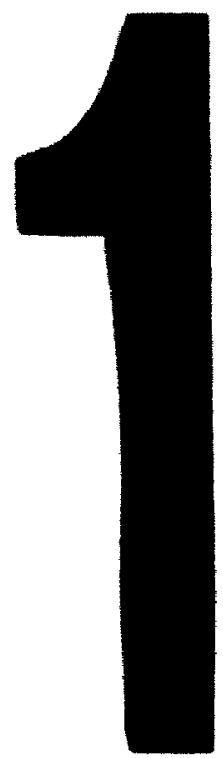

PM. I 31/2"X4" PHOTOGRAPHC MUCROCOPY TARGET Mas 1010a ANSAIISO "2 EOUTMALENT

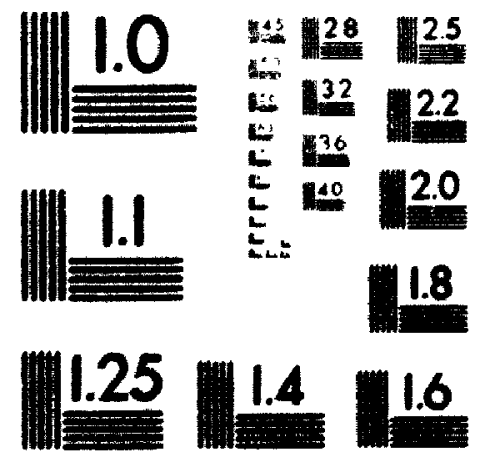

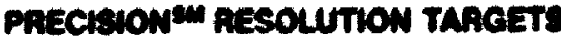


National Library

ol Canada

Acquisitions and

Bibliographic Services Branch

395 Wellingion Street

Onowa Ontano

KIA ONA
Bibliotheque nationale

du Canada

Direction des acquistions el

des services bibliographiques

395, ne Wellungton

Onawa (Ontaro)

KIAONA
NOTICE

The quality of this microform is heavily dependent upon the quality of the original thesis submitted for microfilming. Every effort has been made to ensure the highest quality of reproduction possible.

If pages are missing, contact the university which granted the degree.

Some pages may have indistinct print especially if the original pages were typed with a poor typewriter ribbon or if the university sent us an inferior photocopy.
La qualité de cette microforme dépend grandement de la qualité de la thèse sormise au microfilmage. Nous avons tout fait pour assurer une qualité supérieure de reproduction.

S'il manque des pages, veuillez communiquer avec l'université qui a conféré le grade.

La qualité d'impression de certaines pages peut laisser à désirer, surtout si les pages originales ont été dactylographiées à l'aide d'un ruban usé ou si l'université nous a fait parvenir une photocopie de qualité inférieure.

La reproduction, même partielle, de cette microforme est soumise à la Loi canadienne sur le droit d'auteur, SRC 1970, c. C-30, et ses amendements subséquents.
Reproduction in full or in part of this microform is governed by the Canadian Copyright Act, R.S.C. 1970, c. C-30, and subsequent amendments.

AVIS 
THE FORMATION OF THE TURKISH NATION-STATE

AND RESISTANCE

by

CEYLAN TOKLUOGLU, B. S., M. S.

A thesis submitted to

the Faculty of Graduate Studies and Research

in partial fulfilment of the requirements for the degree of

Doctor of Philosophy

Department of Sociology and Anthropology

Carleton University

Ottawa, Ontario

April 1, 1995

(C) Copyright

1995, Ceylon Tolduogia 
The author has granted an irrevocable non-exclusive licence allowing the National Library of Canada to reproduce, loan, distribute or sell coples of his/her thesis by any means and in any form or format, making this thesis available to interested persons.
L'auteur a accordé une licence irróvocable et non exclusive permettant a la Bibliothèque nationale du Canada de reproduire, prêter, distribuer ou vendre des copies de sa thèse de quelque manière et sous quelque forme que ce soit pour mettre des exemplaires de cette thèse à la disposition des personnes intéressées.

L'auteur conserve la propriété du droit d'auteur qui protège sa these. Ni la thèse ni des extraits substantiels de celle-ci ne doivent être imprimés ou autrement reproduits sans son autorisation. 
Name

Dissertation Abstracts International is arranged by broad, general subject categories. Flease select the one subject which most nearly describes the content of your dissertation Enter the corresponding four digit cods in the spaces provided

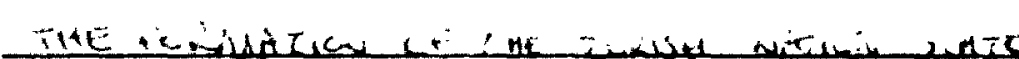

SUPJECT IEAM

C.6.2TC

$\mathrm{U} \cdot \mathrm{M} \cdot \mathbf{I}$

\section{Subjoct Coltegories}

\section{the numanmms ano social senencts}

\begin{tabular}{|c|c|}
\hline 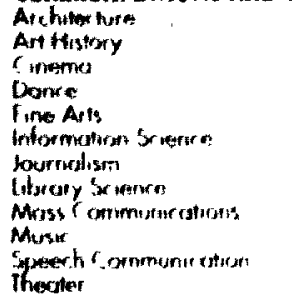 & $\begin{array}{l}0729 \\
0371 \\
0000 \\
0378 \\
0357 \\
6723 \\
0391 \\
0344 \\
0708 \\
0413 \\
6450 \\
0465\end{array}$ \\
\hline 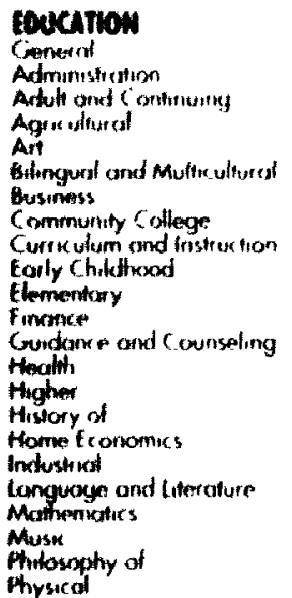 & $\begin{array}{l}6515 \\
0514 \\
0516 \\
0517 \\
0273 \\
0287 \\
0688 \\
0274 \\
0727 \\
0518 \\
0524 \\
0277 \\
0519 \\
0580 \\
0745 \\
0520 \\
0278 \\
0521 \\
0279 \\
0280 \\
0572 \\
0908 \\
0523\end{array}$ \\
\hline
\end{tabular}

\begin{tabular}{|c|}
\hline 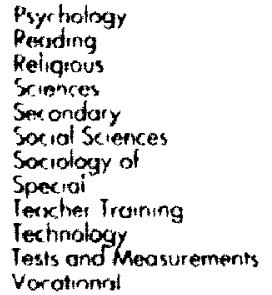 \\
\hline
\end{tabular}

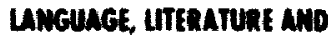 UNGUSTKS}

languoge

Ancient

Lingursics

Midern

Literature

Classical

Comparative

Medievol

Modern

Amicon

Asian

Conodion (English)

Conodian (fiench)

English

Germunic

Latin American

Middle Easter
Romance

Slavic and East European

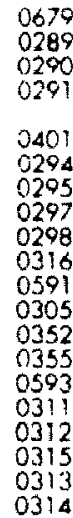

0525

0527

0714

0533

0340

0529

0530

288

0747

\section{American Studies}

Anthropology

$$
\text { Archoeoloy }
$$

Cultural

Business Administration

Genera!

Accouning

Banking

Manogement

Conodian Stidies

Ecoromics

Agriculural

Commerce Business

Finance

History

Labor

Folklore

Geogrophy

Geroniology

History

General
SUBJECT CODE
PHLOSOPHT, RetLGION AMD

Rilosophy

eligion

al Studies

fisiory of

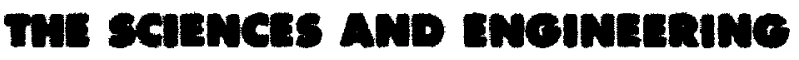

\section{monereu satikas}

Adyriculture

Germal

Animal Cuture and

Animari coltur

Arumal Pothologr

tond Sxuence und

Ienhology

funsiry ond willite

Plani Culiute

Man Patholosay

Plant Physology

Range Munkzyoment

Biology

Geomal

Anvoromy

Broskintistic

boling

fology

Inthrthlaxy

ixtikntifs

Mxridnologr

Moles wlar

Nevilowimas"

Chexinaystophy

Physotixy
Rexilution

Veterinary 5 ience

Inoton:

Breptyons!

Contaren

nin saturs

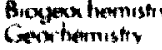

0473

0285

0475

0476

0359

0478

0480

0817

0777

O) 46

0306
0287

0287
0308

0309

0379

0329

0353

$036 \%$

0793

0410

03i,

OAlo

0433

0821

0.78
0472

0780

070

0425

0096
Grodesy

Geology

Geophysics

Mineralogy

Paleobotony

Paleoecology

Poleontology

Paleozoulogy

Palynology

Physical Geography

Physir of Oceanogrophy

Heath awo EnVtronmenta

\section{schivas}

Envionmental Sciences

0768

Nealth Sciences

Germel

Audiology

Dentisity

Educution

Hospital Management

Humun Development

immunology

Mirlicine and Surgery

Mental Health

Norsing

(bsietrics and Gynercology

Occupotional thealth and

Theray 035

Optutholmology

Pathologr

Phou mocologr

Phormacy

Puthic Heoth

Rodrology

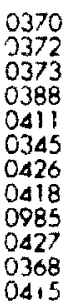

Speerh Pathology

iome Ecology

\section{Pirsteal satwas}

Pure Scionces

Chemistry

Gener af

Agricultura
Anolyical

Biochemistry

inorganic

Organic

Pharmaceutical

Phystcal

Rodyution

Radiction

Mothematics

Physics

Generol

Acoustics

Astronomy and

Astrophysics
Atmospheric Scrence

Alomic

Flectronics and Electricity

High Eny Pan

High Energy
Fluid and Plosma

Moleculor

Nucleor

Optres

Rodicion

Statistics

Apitind sciences

Applied Mectranics

Computer Science
0460
0383

0386

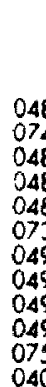

0485

0749
0486

0487

0488

0738

0490

0491

0494

0754

0605

986

0606

0608

0748

0607

0798
0759

0609

0610

0752

0756

061 !

0463

0346

0984
Engineering

Aerospoce

Agricutiural

Automotive

Chemrol

$C \cdot v$

Electronics and Elextrical

Heat and Thermodynomics

Hydraulic

Industrial

Marine

Materials Science

Mechanical

Metallurgy

Mining

Packag

Packaging

Petroleum

System Scuence

Geolechinotogy

Operations Research

Plastics Technology

Textile Tectinology

\section{Promates}

General

Clinical

Developmental

Experimental

Industrial

Personatify

Physiological

Psychobrology

Psychometrics

Social

0537

0536

0539

0540
0541 
The undersigned hereby recommend to

the Faculty of Graduate studies and Research acceptance of the thesis

THE EORMATION OF THE TURKISH NATION-STATE AND RESISTANCE

submitt?d by

Ceylan Tokluoglu-Cesur, B.S., M.S.

in partial fulfilment of the requirements

for the degree of Doctor of Philosophy
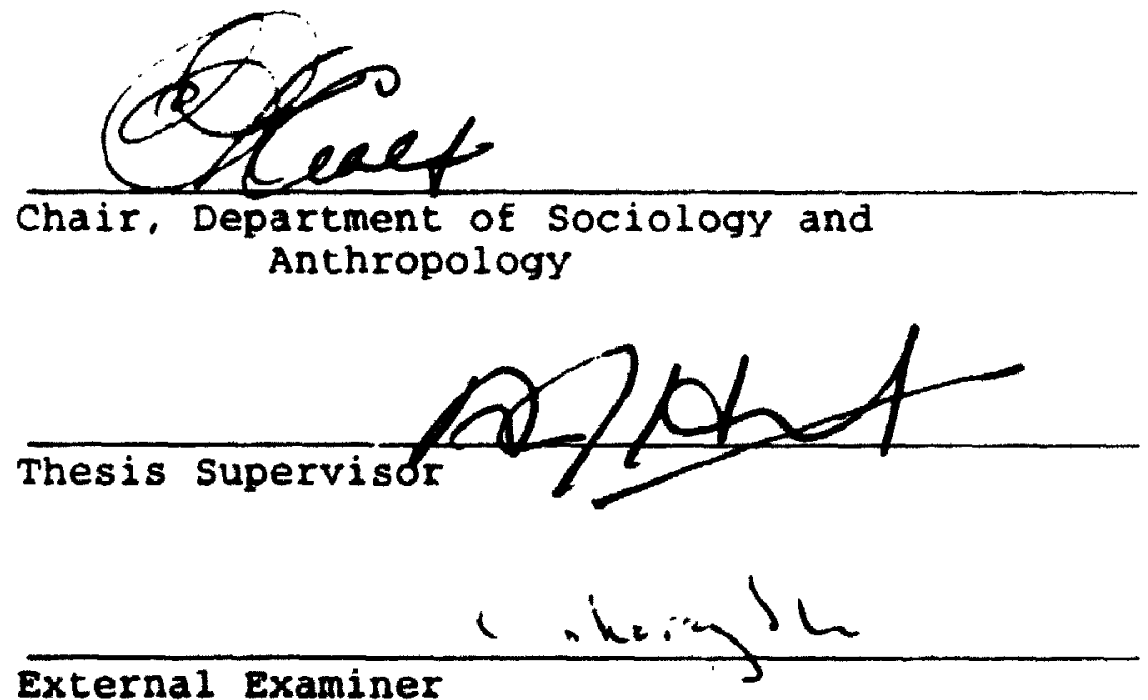

Carleton University

May 12, 1995 


\section{ABSTRACT}

In this study the process of nation-state formation in Turkey is analyzed with reference to various forms of resistance (as distinct from formal pulitical opposition) experienced between the years 1919 and mid-1930s. These include social banditry, military desertion. ethnic and religiously inspired uprisings, non-Muslim and non-Turkist. opposition, and movements against the reforms made by the state epitomized by the case of the hat reform. The process of state-building is analyzed at two separate but related levels with regard to resistance. First is the forms of resistance provoked by the Turkish state and second is the impact of resistance on state-building and its outcome.

One aspect of the process of state-formation is to analyze the major forms and locations of state-formation such as the institutions and the links between these institutions. Another aspect pertains to the structural connections in the process of state-formation such as the relationship between military and civilian development, between central and local state, and some aspects of constitutional development. This study focuses on both aspects of state-formation in order to analyze those social and political processes and forces that led the Turkish state to develop in the way it did.

The model used in this study emphasizes the ideological and cultural aspect of the process of nation-state formation in Turkey which is revealed in various forms of resistance that took place against the state-builders It is argued that, in addition to Turkish nationalism. Islam, ethnicity, and regior alism all served as competing sources for the formation of new identities which in turn influenced the nature and the form of the new state. 
To Ayse

\section{ACKNOWLEDGEMENTS}

I would like to express my thanks to Professor Alan Hunt who has directed this dissertation. I feel indebted to him for his thoughtful, detailed, and valuable comments and criticisms. I would also like to thank to him for the time he has devoted to discussing ide:as throughout the whole writing process and for providing valuable sources which would have otherwise remained unnoticed. Without his great support and encouragement I would not have been able to complete such a difficult task. I feel deeply grateful to him.

Other members of my committee were Professor Wallace Clement and Professor Daiva Stasiulis. I learned a great deal from each of them and benefited from their comments and suggestions. I am obliged to them for their help and support. I am also grateful to Professor Jane Jenson who was a member of my supervising committee until I began writing my dissertation at which time she took a position at another university. Her valuable criticisms and support gave me the courage to continue working at difficult times.

I would also like to thank to Professor Sencer Ayata who helped me to clarify my thoughts during the selection of this dissertation topic and made me aware of some recent debates and publications. All remaining errors are my responsibility. 


\section{Table of Contents}

ABSTRACT iii
ACKNOWLEDGEMENTS iv
TABLE OF CONTENTS $v$
CHAPTER 1
INTRODUCTION

2.1 Introduction 23

2.2 Theories of Nationalism and Nation-Building 24

2.2.1 Introduction 24

2.2.2 Definitions and the Periodization of Nationalism 26

2.2.3 State versus Nation 30

2.2.4 The Role of Ethnicity in the Formation of Nation-States

2.2.5 Conclusion 42

2.3 Theories of State-Formation

49

2.3.1 Introduction 46

2.3.2 Class Based Theories 49

2.3.3 Theories Emphasizing Crisis and State Needs 55

2.3.4 State as the Product of the Social Dynamics 62

2.3.5 Conclusion 68

24 Theories of Resistance Versus State-Formation 71

2.4.1 Introduction 71 
2.4.2 Theoretical Approaches to Resistanic 72

2.4.3 Conclusion 8.3

CHAPTER 3

THE OTTOMAN PAST AND TURKEY BETWEEN THE YEARS OF 1919-1935

3.1 Introduction 92

3.2 Economy and Politics in the Ottoman Empire 93

3.3 Turkey Between the Years of 1919-1923 110

3.4 Formation of the National Assembly and its Aftermath (19231935) 133

3.5 Conclusion 146

CHAPTER 4

FORMS OF RESISTANCE EXPERIENCED IN TURKEY 155

4.1 Introduction 155

4.2 Resistance and the Struggle For National Independence (1919-1923) 190

4.2.1 The National Forces 162

4.2.2 Military Desertion and Social Banditry 165

4.2.3 Internal Revolts During the Independence War 187

4.2.4 Non-Turkish Opposition: Kurdish Resistance 194

4.2.5 The Green Army 199

4.2.6 Non-Muslim Opposition: Amenians and the Greeks of Turkey (Rums) 205

4.3 Resistance and Republican Turkey (1923-1935) 222

4.3.1 Abolition of the Caliphate 224

4.3.2 Religion and Secularism 226

4.3.3 Kurdish Revolts 230

4.3.4 Unification of education in 1924246

4.3.5 The Hat law in $1925 \quad 247$

4.3.6 The Unveiling of Women 253

4.3.7 Reform of the Alphabet in $1928 \quad 256$

4.3.8 Conclusion 258

CHAPTER 5

THE IMPACT OF RESISTANCE ON THE STATE-BUILDING PROCESS IN TURKEY

5.1 Introduction 273

5.2 Forms of Resistance and the Turkish State 274

5.2.1 Nationalism 276 
5.2.2 Armenian and Greek Minorities 286

5.2.3 The Idea of Nation-State 289

5.2.4 Social Banditry and Internal Revolts 291

5.2.5 Reforms and Popular Resistance 301

5.2.6 Kurdish Nationalism 306

5.2.7 Constitutional Developments 313

CHAPTER 6

CONCLUSIONS

326

BIBLIOGRAPHY

338

GLOSSARY OF TURKISH TERMS 361

CHART: MAJOR SOCIAL AND POLITICAL EVENTS IN TURKISH HISTORY $(1919$ - 1935) 363

MAPS OF TURKEY 369

vil 
Text complete; leaf $1-, \bar{Y}$ omitted in numberint. 


\section{CHAPTER 1 INTRODUCTION}

The focus of this study is to explore why there was resistance to the way the Turkish state was built and with what consequences for how we think about state-building. I take resistance as distinct from formal political opposition to include ideological and cultural resistance based on religion, ethnicity, regionalism and gender. This aspect of statebuilding has been regarded as trivial or as secondary in most works on Turkish stateformation. In addition to Turkish nationalism. Islam, ethnicity, and regionalism all served as competing sources for the formation of new identities which in turn influenced the nature and the form of the new state.

My argurient about state-building differs from those others which focus on Turkish statebuilding as a consequence of the process of modemization and Westernization or those which conceivc it as the end result of Turkey's integration to the capitalist world. 
Modernization Westemization and capitalist integration perspectives provide such a model where the state appears as an entity standing heyiond and above the siciety. The model used in this study, on the contrary. emphasizes the ideological and cultural aspect of the process of nation-state formation in Turkey which is revealed in various forms of resistance that took place against the state-builders. To conceptualize state-firmattion in relation to different forms of resistance provides a beller understanding nol only of the dynamics that led to the establishment of a new state. but also of the impact of resistince on the process of state-formation. on the one hand, and the nature of the exercise of stalte power on the other. Moreover, I argue that, when state-building is considered as linked wo various movements of resistance then the state can be conceptualized in close connection to the rest of the society.

The formation of the Turkish nation-state in 1923 has been studied mostly with a ficus either on the 'bureaucrats' as the class which carried out the Turkish Revolution or on the constitutional and le $e_{\text {b. }}$ iative developments which followed the establishment of the state. Also the link between the newly formed Turkish state and the single party rule which
lasted until 1950 has been another prominent area of interest which has been studied
extensively. In these dominant approaches the study of the forms of resistance to state-building has concentrated upon the struggles within the dominant class and within the institutions. Generally it is assumed that the rest of the population had relatively little impact on the establishment of the new state. Whether or not this new form of state was accepted without any opposition from the majority of the population remains an area open to 
further investigation. My interest is in establishing that there was resistance to the process of state-building from various sections of the population. most of which were linked to the peasantry which constituted the bulk of the population.

The process of state formation can be conceptualized as a broad process extending beyond the establishment of new institutions or of the formation and transformation of social classes. The dynamic relationship between state formation and society creates many points of intersection which affect even the most personal social relations. This makes it possible to consider various types of power struggles as being linked to the state formation processes. State formation may take different forms in different locations. For example, at the level of constitutional developments the state appears in a more abstract form whereas at the cultural level state practices can reveal more about the actual relations between the state makers on the one hand and those involved in the political processes on the other hand (either supporting or resisting the process of state formation). Also, depending on the forms of struggle between the state makers and their opponenis or supporters, these various forms of state formation can reveal the character of the state in a more detailed way.

In this context, the link between the process of state formation and various forms of resistance to this process anpear as an essential dimension for grasping the dynamics of the period from 1919 to the 1930s in Turkey. This period has two subdivisions which are both related to the formation of the new Turkish state. The groups and actors involved in the process of state-building were different in the two periods. The Ottoman Empire was defeated when World War I ended in 1918. The Turkish War of Independence, which 
took place between 1919 and 1923, constitutes the first period of the state formation process. The second period roughly covers the years between 1923 and the late 1930s. Although the new state was established in 1923 its authority was significantly challenged until the early 1930s. In this respect. this second period also constitutes part of the stateformation process.

In this dissertation I examine the different forms of resistance tn state-building in Turkey. These include social banditry, military desertion, ethnic and religious uprisings, nonMuslim and non-Turkish opposition. and movements against the reforms made by the state epitomised by the case of the hat reform. These movements of resistance varied from one place to another and also took different forms over time. Resistance to state formation cannot be separated from the beliefs, values, common-sense, and attitudes of those resisting the state. In other words, there is always a type of confrontation between the state makers and various groups belonging to a specific culture other than the powerful or dominant one. 1 also discuss those 'supportive' and 'reactionary' (which are neither 'against' nor 'supportive' of the developments which took place in Turkey during the period under investigation) movements for two reasons. First, together with resistance movements, they reflect the border between what can be classified as 'for' or 'against' state-building. Second. although they were not influential in the formation of the Turkish state, they reflect those critical points of transition in relating cultural and pre-political forms of resistance to the process of state-formation. The inclusion of all these movements (resistance, support, and reaction) is necessary for discussing the changes in location of authority and power. 
A focus on uninstitutionalized forms of resistance against state-building cannot be separated from the cultural conflicts of the period representing the constant struggle between the national authorities and alternative power groups as part of the peasantry influenced by the discourses of popular culture. Social banditry, military desertion, and other types of individual/unorganized resistance movements - such as those movements resisting the hat reform, the unveiling of women, or the acceptance of the latin alphabet all reveal the conflicts other than the ones which took place within the dominant classes or institutions. In addition, physical attacks on military officers who represented the state was another form of resistance which again was inherited from Ottoman times and continued as a practice against state-makers in the formative years of the Turkish state.

There were also some other forms of local resistance to the state which were basically religious and ethnic in character. These religious and ethnic movements often resulted in revolts which had a different dynamic compared to the former forms of resistance, such as social banditry and military desertion. While the main motive behind these revolts was to preserve the Islamic and ethnic (mostly Kurdish) identity, social banditry or military desertion were forms of resistance to state authority with no clear program to follow. Also ethnic and religious revolts became the dominant form of resistance after the establishment of the Turkish state. Numerous internal upheavals were witnessed in Anatolia during the formation of the Turkish state. The rebellions which occurred between the years 1919 and 1921 reflected the reactions of those groups supporting the Sultan-Caliph. Some of these rebellions were organized by the leaders of the Kurdish tribes demanding independence from the Ankara government. The Circassians and the 
Greeks of Turkish nationality. too. were involved in a number of revolts which took place during this period. Similarly, the revolts which occurred between the years 1924 and 1938, following the abolition of the Caliphate, were all related (except for one) to the Kurdish tribes and to their religious leaders. The form of the state-building process was not the same during the War of Independence and in its aftermath. As a result both periods provoked different forms of resistance which in turn shaped the nature and the form of the state in their own ways. In general, resistance in Turkey was very closely linked to the struggle against state authority, both during the War of Independence and in its aftermath. In this dissertation I argue that resistance to state-formation was almost always pre-capitalist in form, and the local revolts never reflected a unified peasant dissatisfaction with the building of the Turkish state.

State-building and resistance are connected to one another in two different ways. The process of state-building can be analyzed at two separate but related levels with regard to resistance. On the one hand, state-building provokes resistance. On the other hand, resistance shapes the nature and the form of the process of state-making and its outcome.

The forms of resistance provoked by the state provide the grounds for looking at the power struggles among various groups in any phase of the state-making process. At this level one can also see the cultural relations between the state-makers and those resisting. Moreover, to examine various forms of resistance movements enables one to focus on the structural connections in the process of state-formation such as the relationship between military and civilian development, and between central and local state. The second part of the state-building process reflects the impact of resistance to state-building. Here 
analyzing the responses of the state to resistance is crucial for understanding how resistance shapes the form of the state.

My primary concern is to analyze the impact of resistance on state-formation. I also analyze the forms of resistance provoked by the Turkish state in order to be able to discuss the reasons for popular discontent against state-builders. Since those involved in movements of resistance were largely part of the peasantry, their confrontation with the state constitutes an area revealing the ways through which power was exercised within Turkish society. For without taking into consideration the resistance side of any relation of domination, power struggles (their location and the methods used) cannot be fully grasped. Here I follow Foucault who conceptualizes the exercise of power as a way in which specific actions modify others. In this context, again following Foucault, what resistance reveals about the exercise of state power is how power relations progressively became elaborated, rationalized, and centralized in the form of state institutions (1982, p. 219. 224).

I assume that the silence about resistance in the Turkish literature has influenced the conceptualization of the Turkish state and its formation. This study will explore some of the consequences of these silences in terms of conceptualizing state-formation (and state policies) in Turkey. I argue that Turkish nationalism developed as a response both to foreign invasion and to the development of non-Muslim nationalisms. In fact, nonMuslim opposition became a tuming point for the transformation from cultural nationalism (adopted by the Young Turks) to political nationalism on which the idea of forming a 'nation-state' and of 'Turkey' were built. In addition, non-Turkish resistance to 
the Nationalists, too, significantly influenced the form of the state and its policies towards building a nation-state. Secularism and populism. together with Turkish nationalism. became the principles on which the nation-state was built. The form of the new Turkish state was basically the West European one but the path of development was. however. divergent and distinct from that of the West European states.

Following Gellner, the process of state-building in Turkey can be characterized as a process of 'forced homogenization' to bring about the unity of 'culture' and 'polity'. I discuss the nature of this process and argue that the attempt to homogenize the society has been incomplete since linguistic, cultural, and religious diversity continued to prevail in the periphery. The tension between 'modemity' and 'tradition' still exists in Turkey today.

Here I briefly locate my research question in the substantive literature on Turkey focusing only on the dominant trends in the literature.

The Turkish nation-state was formed under the leadership of a military-bureaucratic elite in 1923. The key role played by the military is mostly taken as a point of departure when analyzing the formation of the Turkish nation-state in comparison to the West European pattern. Relying too heavily on military-bureaucrats as the primary actors in the Turkish Revolution leads to overemphasizing the historical role played by this class. What follows from this perspective is that the struggles and rransformations within the ruling class and its alliances with other classes becomes the focus of analysis in many works on Turkey. 
At a broader level the process of state-formation in Turkey is reduced to analyzing the process of class formation which are two related but separate processes. Although the Turkish case is used as an example to separate dominant classes from the rulers of the stite (e.g. Skocpol 1985, and Trimberger 1978), studies of state-formation in Turkey rely heavily on the process of class formation. Equating state formation with class formation constitutes the grounds for focusing on the link between the dominant classes and the institutions, political parties, and constitutional-legislative developments.

This dominant trend is not unique to Turkey. The way states in the Third World are distinguished from advanced capitalist states structures the framework for analyzing the process of state-formation in the Third World countries.

World systems theory and modernization theory are the two dominant theories in the Turkish literature. According to the first theory, economic relations of production both between and within countries are the key to understanding the functioning of states. In this model capitalism, industrialism, and the bureaucracy constitute the core concepts. The role played by the state in reproducing class domination through the relations of production appears as the most important role that the state undertakes. In this model Turkey is placed among those countries (such as China and Japan) which experienced a 'non-colonial peripheralisation' with regard to the world economic relations. Keyder argues that the absence of colonisation and the relative autonomy (vis-a-vis imperialist pressure) of the traditional bureaucracy in the Ottoman Empire shaped the process of peripheralisation experienced in Turkey (1988, p. 192). Consequently, in Keyder's world systems model. capitalist integration and modemization (or Westemization) as the 
program of the bureaucratic class have been the principal parameters for analyzing the Turkish state.

In contrast, modernization theory emphasizes the impact of Westernization or modernization on the building of states. Here states are rtduced to the policies implemented by state-makers. In the Turkish case the constitutional and legislative developments which followed the establishment of the new state receive great attention in discussing the impact of modernization on the process of state-formation.

In this context, the link between the new state and the Republican People's Party (RPP) becomes the major area of interest in discussing the nature of the Turkish state. The Republican People's Party, which ruled until 1950 as the single party in power, was established by those who carried out the Turkish Revolution. As Gunes-Ayata notes, "in 1923. when the Republic was founded, the party was inseparable from the state. The notables in different parts of Turkey became both representatives of the party and the agents of the state in the periphery" (1990, p. 164).

Based on this link between the RPP and the state, the policies of the RPP come to the fore as manifestations of Westemization (or modemization) imposed upon the masses by the state-makers. For example, Ozbudun argues that,

modemization (or Westemization), as was understood by the RPP leadership. involved mainly the adoption of Western political and cultural institutions with no radical change in the social structure. The local nobility, being relatively welleducated and exposed to Westem civilization, was moce likely to support such a program than the more traditionally .riented peasant masses, provided that the Revolution did not touch the sources of their local power...The local nobility supported the modemization program of the national military-bureaucratic elite, in 
return for which it was allowed to retain its land. status, and local influence ( 1970. p. 389).

Both of these perspectives, the world system theory and the modernization theory, do not take into account the internal characteristics of the power structures or conflicts within the Turkish society. Tilly's separation between the 'internal' and 'external' history of statemaking can be applied to the Turkish case (1981 p. 45). What Tilly calls the external history, which looks at the ways through which states acquire control over education. welfare, marriage, natural resources, and economic activity, constitutes the dominant approach to the Turkish state-formation. The internal history of state-making analyzes how particular organizations grew up that asserted dominance over their 'own' populations. In this context, the internal history of state-making provides the grounds for studying those conditions under which riots, rebellions, and revolutions occur, which is an area open to further study in the Turkish literature.

What follows from these dominant perspectives is that resistance to the state-makers in Turkey is narrowed down to the struggles within the dominant class or within institutions. Organized and formal opposition is regarded as the only form of opposition deserving attention. For example, in comparison to the Ottoman past, Mardin argues that “opposition movements were no luckier during the Republic. Between the establishment of the Republic and the year 1932 the opposition was stamped out twice...In the first case the opposing party was the Progressive Party (Terrakkiperver Firka)... The second time the victim was the Free Party (Serbest Firka) which had attracted considerable interest and following" (1965, pp. 377-378). 
Various non-institutional (and also individual) forms of resistance experienced in Turkey are regarded as trivial and incidental with regard to the process of state-making. However. state-formation provokes various forms of unorganized Nindividual opposition alor.gside formally organized collective political opposition. As Yalman states. "in Turkey, the disproportion between the struggle engaged in and the resources available did not cause an open revolution, as in Russia. The body was so feeble and so unorganized that it went on to its agony without any collective resistance. Thcre were. however, unmistakable signs that complete exhaustion and breakdown were only a question of time" (1930, p. 261).

In this dissertation I relied heavily on secondary sources, both in Turkish and English, on state-formation in Turkey written by sociologists, historians and political scientists. Sources written by sociologists are limited, especially those pertaining to resistance and opposition movements during the period of Turkish history under investigation. I filled the gaps using various memoirs written by Turkish and foreign high-ranking military officers, bureaucrats and members of the parliament, Turkish nationalists, journalists, and Christian missionaries most of which were personally involved in the Turkish War of Independence and in the renovations following the war. In this respect the memoirs I used are considered primary sources. Moreover, some of the secondary sources I have used rely heavily on primary documents such as the Minutes and Official Proceedings of the Grand National Assembly, official government documents, official letters, Official Gazette, public reports, life histories, and oral histories. 
Until 1928, the alphabet used in all original documents was Arabic, which is a major handicap for researchers. Yet some documents prior to 1928 are now available both in Latin and Arabic letters. Most of the sources written by Turkish scholars are based on these translated documents such as those on the Sheikh Sait Revolt which took place in 1925.

I tried to bring the research a comparative view by evaluating both Turkish and foreign memoirs. Moreover. to preserve objectivity. I tried to prevent reflecting biased views by consulting both Turkish and foreign sources.

In Chapter Two I discuss the theoretical framework I use. First I elaborate on the relationship between state-formation and nationalism-ethnicity, and modernity. I critically review the current trends in the literature which implies a necessary link between the process of modemization-industrialization and nation-state building and nationalism. Then I review the literature on state-formation and theories of resistance separately, and focus on the central concepts that are relevant for the purpose of this study.

In Chapter Three I first describe the characteristic aspects of the Ottoman society and relate the Turkish Revolution to its Ottoman past focusing on the specifics of the revolution. Secondly, I discuss the key political and social transformations both during the Turkish War of Independence and during the formative years of the new Turkish state. In this context, I also refer to parliamentary political opposition that took place in connection with these broader transformations. 
In Chapter Four I analyze the various forms of resistance that the Turkish state faced both during the War of Independence (1919-1923) and in its aftermath (1923-early 1930s) under separate headings. I look at social banditry and peasant resistance. opposition movements in Istanbul, non-Muslim opposition. and religious and ethnic resistance movements.

Finally. in Chapter Five I focus on the impact of resistance on the state-building proxess in Turkey. I analyze the relationship between various forms of resistance and the Turkish state, and discuss the consequences of resistance for the Turkish state. 


\section{CHAPTER 2 THEORETICAL FRAMEWORK}

\subsection{Introduction}

In this chapter I review the literature on theories of state-formation and theories of resistance, and discuss the central concepts that are relevant for this study. Before focusing on these theories, I first discuss the relationship between state-formation. nationalism-ethnicity, and modernity. The debates on nation-building and on statebuilding often remain two separate bodies of theory. Nation-building and stale-building are historically connected, yet they have often been treated as distinct from one another. I critically review the current trends in the literature which implies a necessary link between the process of modernization-industrialization and nation-state building and nationalism, 
since this has been the underlying assumption of dominant approaches analyzing the formation of the Turkish state.

My discussion focuses on theories of nationalism and nation-building. theories of stateformation. and theories of resistance under separate headings. I map out the major debates and approaches within the literature, and then elaborate on those theories which best explain the process of state-building in Turkey and the forms of resistance that towk place against this process.

\subsection{Theorles of Nationalism and Nation-Bullding}

\subsubsection{Introduction}

The concept of nationalism is a broad and an ambiguous concept loaded with many different elements and meanings which lead to significant terminological problems that constitute an obstacle at the level of theory. In the literature such concepts as nationalism. nation, state, national minority, and ethnic group are all related to one another in complex ways. In this respect, what constitutes a 'national movement' itself becomes a controversial issue. Generally the formation of nation-states, national liberation movements, modern forms of separatist or unificatory nationalism, and ethnic movements are all embraced by the concept 'nationalism'.

It is important to distinguish between nation-state, nation, modern state, and nationalism to clarify the concept of state-formation. Secondly, it is necessary to distinguish various forms of nationalism discussed in the literature such as nation-building, national integration, reform nationalism, colonial nationalism, and separatist nationalism. Also old 
and new nation-states should be distinguished from one another. All these divisions within the literature of nationalism are based on a more basic distinction between two forms of nationalism, 'classical' and 'modem' rationalism. The relationship between these two types has given rise to many contradictory perspectives with different theoretical implications.

The relationship between nationalism and state is the most fundamental one since all national movements either aim at forming states or at gaining control of an already existing state. This relationship between nationalism and state was different in the classical period compared to the present. To analyze the different meanings and definitions of the nation-state, modem state, nation and nationalism, and to analyze the changing relations between them can provide the grounds for discussing the relationship between nationalism and state. Hence whether 'nations create states' or 'states create nations' becomes the most essential question to be discussed since it is this relationship between 'state' and 'nation' that becomes the point of departure for various theories of nationalism. Within this framework the conditions under which an ethnic group organizes itself as a nation can also be identified.

I now briefly refer to the classical Marxist and neo-Marxist accounts of nationalism which assert that nationalism stands in a necessary relationship to capitalist development. I find Gellner's perspective on nationalism useful which can be defined as a non-Marxist perspective. However, Gellner's non-Marxist perspective, in some ways, converges with the neo-Marxist accounts on nationalism. For example, Gellner, too, argues that there is a necessary relationship between industrialism and the development of nation-states. 
However. similar to the neo-Marxist perspective, he does not associate the ideology of nationalism with the economic class interests of the bourgeoisie as does classical Marxism. On the contrary, he emphasizes the cultural dimension of nationalism and I share his views.

\subsubsection{Definitions and the Periodization of Nationalism}

Within (classical) Marxist and neo-Marxist theories of nationalism there are various arvas of controversies. Nevertheless, all accounts agree that the nation-state is the only viable form of polity in the modern world. However, questions such as which conception of nationalism is appropriate for understanding the contemporary world is one of the main areas of discussion. For example, one perspective argues that national struggles are appropriate only to the period of rising capitalism and national movements are strategies appropriate to the rising bourgeoisie.[1] In contrast to this view, there is a second perspective arguing that independence movements constitute a different form of nationalism which cannot be directly associated either with carly capitalism or with the bourgeoisie.[2]

This debate raises the central questions: Does nationalism have a class base? How should one periodize the history of nationalist struggles in order to distinguish various types of nationalism? The discussion of these questions requires an examination of various definitions and meanings of nationalism.

The state and the nation are two concepts related to one another although there is no necessary and logical link between them. However, there is a tendency in the literature to 
identify the state with the nation which is linked to the historical fact that nationalism in the West has been the central force in the develupment of nation-states.[3] It is necessary to separate the 'state' from the 'nation' since the state can extend beyond the boundaries of a nation. In this respect the state can or cannot be equated with a single 'nationality' because almost all states represent more than one nationality.[4] At this point it is necessary to distinguish between the terms 'nationality' and 'nation'. I quote from Haddad who studied Ottoman nationalism, and whose views I share.

The term nationality as commonly used today, denotes citizenship. However, nationality, as it was originally envisaged in Western Europe, carried with it certain characteristics that defined a group of people. These characteristics included the belief in a common descent, the same language, the same territory, a political entity, religion, customs, and traditions. Such a conglomerate of people possessing the same nationality was called a nation. This group of people did not have to possess all the characteristics that defined a "nationality" in order to call themselves a "nation". Thus, one may speak of the United States of America as a nation, though it is not racially homogeneous; and of a Palestinian nation, even though the latter does not now possess a finite territory $(1977$, p. 7$)$.

Also the terms 'state' and 'nation-state' should be separated from federal states (or multiethnic states), and from supranational structures such as the European Community. The state may be national or multinational.[5] The term nation-state requires further elaboration. Again in Haddad's words:

In contemporary usage the term pation-state has come to mean the political and territorial expression of the nation. Actually, the idea of nation and nationality are quite old. dating back to the times of the Greek and Hebrew peoples. However, the contemporary idea of the secular nation-state was not fully developed until late in the eighteenth or early nineteenth century. Before that time one found religious, dynastic, or multinational states. Nonetheless, by the nineteenth century, the ideal political entity came to be identified in the West as the single-nationality state... This nation-state would also serve to preserve and enhance each nation's nationality. This belief has formed the basis for a definition of the last concept, 
nationalism. Nationalism arose in Western Europe largely as a result of the bourgeois French Revolution (1977. pp. 7-8).

This association of the concept of nation-state with the period of early capitalism which gave rise to the formation of many independent states in Westem Europe can be seen as the basis of the misleading conclusion that all national struggles were - and still are carried out by the bourgeoisie as was the case in Westem Europe during the period of early capitalism.

The classical Marxist position sees nationalism as stemming from economic class conflict alone. This position clearly associates the ideology of nationalism with the economic class interests of the bourgeoisie. In this respect, nationalism is an ideology and like all ideologies it has a necessary class belonging. Moreover, all communal interests other than the economic interests of the bourgeoisie are treated as if they play no independent role in the sphere of political struggle. Broadly. it is assumed that the socialist revolution will automatically solve any type of social antagonism - such as national conficts - by eliminating class conflict.[6]

European experience of state formation constitutes the source for those views which equate the state with nation. The European nation-states were created in connection to rising capitalism and with the deliberate efforts of the bourgeoisie. The classical Marxist position, drawing largely on this European experience, asserts that all national struggles are necessarily bourgeois struggles.

I argue against this position since with the development of capitalism, modernization, and changing forms of intemational relations the ways in which states have been formed in the 
twentieth century have changed. Moreover. not all independence struggles of the twentieth century can be regarded as bourgeois revolutions. For example, the classical Marxist model of nationalism does not apply to Ottoman nationalism and to the process of Turkish nation-state building. For, although the Turkish Revolution provided the necessary conditions for capitalist development in Turkey, the building of the Turkish nation-state was not carried out by a bourgeoisie and, "at that time, the intelligentsia of the Ottoman Empire were hardly ever interested in explaining the economic domain and in various theories about this domain but, orienting their intellectual praxis to mostly nationhood and the political realm" (Cesur-Baykan 1988, p. 121).

From a neo-Marxist perspective, contrary to classical Marxist position, nationalism is a form of politics which does not necessarily have a class base and nationalism does not always stems from economic class conflict alone. Moreover, all national struggles are struggles for state power which can only be understood in relation to the state.[7] However, I do not take the state as a reified and autonomous institution separated from other institutions, collectivities and various social processes. The state is connected to the economic, political and cultural processes and does not merely reflect the economic interests of the ruling classes.

As suggested by the neo-Marxist perspective, nationalism is about the formation of nation-states and it cannot always be reduced to class divisions. In this sense specific historical circumstances and processes, and the national history of a given country are important in identifying the form and nature of the nationalism under investigation. The bourgeois state-building process specific to Western Europe cannot provide the adequate 
grounds for regarding the later national movements as having a necessary class base. [8] The model of 'classical nationalism' is not pertinent for explaining more recent forms of nationalism such as anti-colonial struggles or contemporary national liberation movements of the twentieth century. Next I discuss various forms of nationalism in order to clarify the link between the state and nation.

\subsubsection{State versus Nation}

Returning to the question of whether nations create states or states create nations, two perspectives can be identified. The first perspective insists that states create and invent nations. Gellner's model is a good example of this position. Acconding to Gellner. nations and states are not the same thing and the idea of a nation is created by the state. The modern industrial state can only function with the creation of nations which are 'culturally homogeneous' units (1983, p. 46). The process of nation-state building results in the disappearance of the segmented society. Moreover, nationalism is a process through which forced homogenization is attained through the convergence of political and cultural units. Gellner's argument shifts the attention from both the classical and neoMarxist positions by emphasizing the cultural dimension of nationalism.

The second position argues that nations create states. Benedict Anderson's argument is an example to this second position. Anderson's definition of nationalism as an 'imagined community' points to the fact that nations can exist prior to the development of an independent state of their own (Anderson 1983). It is useful to conceptualize nationalism in this way because of the emphasis given to cultural systems as part of political life. 
Palestinian and Kurdish nationalism are two examples where a 'nation' exists without a state of their own.

These models, although they are mutually exclusive. provide a framework not only for West-European forms of nationalism but also for both CentranEast European and Asian forms of nationalism. In addition to these, more recent forms of nationalism which are characteristic of present day Western societies can be studied through these models as well. More specifically, Gellner's distinction between 'culture' and 'structure' is an important one in analyzing particularistic, ethnic, linguistic, and religious opposition to official state nationalisms. For culture is more important in the present than in the past. It provides various sources, such as folk cultures, to identify with (Gellner 1983). Thus the ideology of modem nationalism is capable of providing space for particularistic identities while presenting a 'high culture' and building a mass society. In other words one can argue that formal state nationalisms provoke the creation of counter-nationalisms within an existing nation-state which is a characteristic of twentieth century nationalism.

The point made by Breuilly is important since he argues that political confict shifts away from the core political community of the state towards sections of society hitherto excluded from political life. In his view, this shift provides the particular conditions necessary for the development of nationalist aspirations (Breuilly 1982, p. 36). In short, Gellner's model can be applied to both phases of nationalism, classical and modem. On the one hand, it explains forced homogenization of societies in the process of building nation-states, on the other it explains particularistic ethnic-linguistic opposition movements challenging the status quo that is a characteristic of modem nationalism. I 
argue that Geliner's model - although it sees the development of nations and nationalistic ideologies as the end results of the creation of states - can be applied to the Ottoman case when explaining the transition from a multi-national. multi-religious and multicivilizational system to a modern state-system. I further argue that the process of Turkish nation-state building was at the same time a cultural homogenization process which supports Gellner's argument. This process of nation-state building has resulted in the disappearance of the segmented Ottoman society (Cesur-Baykan 1988, p. 44). I elaborate on this point in more detail toward the end of this section.

I now compare West European nationalism with the nationalism in the Ottoman Empire. This comparison necessitates a distinction between two forms of nationalism. classical and modem. which is firmly linked to the question whether nations create states or states create nations.

Kohn provides a very useful model for a comparative study of nationalism. Haddad summarizes Kohn's position as follows,

He wrote that in the West the nation-state preceded both nationalism and the nation. The most famous example of this was England, which emerged as a state before there was an English people. The opposite was true in Central and Eastem Europe and in Asia, where the nationality was clearly identified by the nation before the nation-state emerged. As a result, the nations in those regions had to fight to gain their 'historic' lands, as in the German case (1977, p. 10).

Based on Kohn's perspective, Haddad argues that "in those areas of the Ottoman Empire that gained their independence after World War I, the tendency has been to build the nation-state on myths of the past and to be more warlike, elevating the state to an erd in itself rather than a means for improving the conditions of its citizens" (Haddad 1977.p. 
11). The Ottoman Empire was a 'non-national' state (a term used by Haddad) and its political system, which was dynastic and religiously based, stands in sharp opposition to the political systems of Western nation-states which are secular and populist by their nature. In this respect, the conventional interpretation of European secular nationalism is 100 narrow to be applied to the Ottoman Empire and to the emergence of nation-states out of the territories of the Otoman Empire (e.g. the Bulgarians, the Serbs, the Greeks, the Turks, and the Arabs).

The spread of Western secular nationalism was not the only and most important force motivating the breakup of the Ottoman Empire. Smith, Naim, and, to a certain extent. Hobsbawm explain the diffusion of nationalism from the West to the rest of the world through the concept of uneven capitalist development. What is implicit in this evolutionary argument is that all forms of nationalism are manifestations of Western nationalism. I do not deny the importance of Western ideas in the process of building new nation-states outside of Europe. However, in the case of the Ottoman Empire, the political organization of the Empire and the internal unrest after the mid-nineteenth century played a more important role in explaining the emergence of numerous nation-states which led to the breakup of the Empire.

In the Ottoman Empire the nationalities were already formed before the emergence of the nation-states. The Ottoman Empire was divided into numerous millets which were religious and ethnic communities, and they were nearly equivalent to 'nation'. Among these millets were the Muslims, Orthodox Greeks, Gregorian Armenians, Jews and Catholics. In Cesur-Baykan's words. 
Religion was the basic factor that differentiated one millet from another. It was difficult to differentiate them on the basis of language, as a national criterion. since different languages were spoken by each of them. For example, many Greeks and Armenians spoke Turkish, Bulgarians spoke Greek and so forth. Secondly, the geographical distribution of the populations of the various millet groups were such that they could be found all over the Empire and no single place could claim a homogeneous population. Before the eighteenth century all members of the different millets were held together by the Ottoman state system that considered all of the ruled population as the reaya, the term that denoted both the Muslims and the Christians but, which later came to designate only the Christian population (1988. pp. 45-46).

This political organization created a series of 'nations' or 'nationalities' which provided the basis for the later growth of nationalism (Karpat 1973). Thus Kohn's model clearly fits into the Ottoman case - and to the formation of the Turkish nation-state - as different from the West European model of nation-state building and nationalism. In the Ottoman case the nationalist ideologies were effective and 'nationalities' were already formed before the establishment of the nation-states.

Geliner's conceptualization of the pre-modern period is helpful in explaining the principles of the millet system in the Ottoman Empire (Cesur-Baykan 1988. p. 121). According to Gellner, in agrarian societies cultural groups do not identify with the state. This was the case in the Ottoman Empire where the millets did not identify themselves with the Ottoman state. In Gellner's view various cultural groups governed by clericyliterati are linked to the state through the clericy and this relationship between the state and the clericy is fundamental for the emergence of nation-states. In his words, "what happens if the clericy one day is universalized, becomes coextensive with the entire society...The answer to this question, and the specification of the nature of that 
transformation, will turn out to be crucial for the understanding of nationalism" (Gellner 1983. p. 17).

The millet system in the Ottoman Empire, based as it was on religious differentiation, was the basis of the communal order. Accordingly,

each intensively regulated its domain of everyday conduct, issues of family. marriage, culture, education, training and electing of religious personnel. communal chiefs, etc. Furthermore, the collection of revenues, security maintenance at the communal level, and later even prisons for ordinary criminals were regulated by the millet organization. Even the cities in the Ottoman Empire were spatially divided into neighbourhoods of millets with gates and gatekeepers...The class division of the empire applied to each millet, with the ruling (askeri) class and the subjects (reaya)...Another instrument uniting the diverse populations of each millet was the bead of the religious community such as the patriarch of the Orthodox Christians (Cesur-Baykan 1988. pp. 137-138).

It was out of this system that numerous nation-states developed. The local rulers were integrated into the international system of the Western civilization. In Haddad's words.

different religious groups and the support, especially in the Balkans, for these groups by European religious champions was a prime cause for the eventual breakup of the Ottoman Empire... Although nationalism, as it was promulgated in the nineteenth and twentieth centuries, was secular, there was an attempt to elevate the national chunches, to venerate them as the national souls, and to incorporate them into the budding nationalist movements. The church was viewed as the repository of national identity in the period prior to the rise of modern nationalism (Haddad 1977, p. 12).

Eventually the Westem separation of the political domain from the power of the church was generalized into the millet system which was now economically and culturally integrated into the West (Cesur-Baykan 1988, p. 139).

The breakup of the Otoman Empire and the emergence of new nation-states following this breakup does not exactly fit into the West European pattern of nation-state formation. 
Thus the differences between Western and non-Western states should not be overlooked. However. the Western influence in the building of modern nation-states cannot be denied. In the Ottoman case each of the newly formed nation-states were all influenced in varying degrees by secular European nationalism.

In Europe the notions of nation and nationality did not develop until the French Revolution. According to Kohn, at the beginning of the seventeenth century the national states of Western Europe were still regarding themselves as parts of the one Christian polity. Universalism broke up, not in favour of nationalities which were yet nonexistent, but to the advantage of the newly risen power of states and princes. Consequently. "etatism. not nationalism, emerged from the disintegration of medieval universalism. The dynasty took the place of religion; loyalty centered in the prince" (Kohn 1958. pp. 187188). Following these developments the new state freed itself from the domination of the Church.

The newly created centralized states formed the basis of the association of state and nationality. According to Kohn, nationalism is the process of the integration of the people into a common political system and. "nationalism is unthinkable before the emergence of the modem state in the period from the sixteenth to the eighteenth century" (Kohn 1958. p. 4).

Ottoman nationalism and the breakdown of the Empire cannot be seen as a Westem-style process from a traditional religious society towards secular nationalism. As claimed by Cesur-Baykan. "nationalism in the Ottoman empire was not merely a transfer of loyalty 
from the religious to the political institutions" (1988, p. 42). The Ottoman state was not a Turkish state before the establishment of the Turkish nation-state. On the contrary, the Turkish nation-state was one of the various other nation-states which came out of the breakdown of the multi-national Ottoman Empire. The formation of these nation-states were not guided by bourgeois classes. For example the Turkish Revolution, which was a revolution from above led by the bureaucracy, was not a bourgeois revolution and the aim was to create a national bourgeoisie after the establishment of the Turkish nation-state.

However, Ottoman transformation cannot be explained as a process of pure Westernization. Religious, economic and political unrest together with Western influence played an important role in the Ottoman transformation. The nationalities in the Ottoman Empire. as a form of religious and ethnic communal organization, were controlled through the millet system. In this respect ethnic and national ideriicies among the former Ottoman peoples are fundamental for understanding Ottoman nationalism. For the nationality problem in the Ottoman state is a special form of nationalism and is different both from the Western European and from recent Asian and African nationalisms (Karpat 1973, p. 3; Haddad 1977). To conclude, the millet system. laying the grounds for the formation of nationalities, initiated the emergence of both the nationalist movements and of nationstates.

\subsubsection{The Role of Ethnielty in the Formation of Notion-States}

Two distinct approaches to ethnicity can be identified. The first approach sees ethnicity as having no relation to the modern nation-state. Hobsbawm's conceptualization of ethnicity 
is an example of this line of thought. According to Hobsbawm. the base of an ethnic group is cultural rather than biological. For him ethnicity is something which can initiate the formation of 'proto-nations'. Hobsbawm refers to the Kurds as an example of a proto. nation. However, for him. such ethnicity has no historic relation to the modem nation. namely the formation of a nation-state (1990, p. 63). Hobsbawm argues that the most obvious ethnic differences have played a rather small part in the genesis of modern nationalism.

Hobsbawm clearly eliminates the role of ethnicity, alongside the role of religion and language, in the process of 'binding together' some group of social subjects into a selfconceived identity. This position can be criticized. Ethnicity and nation cannot be conceived as two entirely separate concepts. Such criteria like language, religion and culture can apply to the formation of both ethnic and nationalistic identities. For example. the Kurds cannot be conceived merely as an ethnic community since, scattered across three states, they separate themselves as a nation on the basis of a common ethnic origin. and claim national independence.

I claim that ethnicity does play a role in the formation of national movements although it is not identical with the whole of that process. As discussed above, the millet organization of the Ottoman Empire was based on religious and ethnic differences which later provided the grounds for the development of 'nations' and 'nationalities'. The millet system was very important since it operated as a source of identity. It reflected existing identities rather than created such identities. The Ottoman state regrouped the already existing ethnic, religious, social and economic groups into a new organizational framework. The 
principal purpose in doing so was to separate groups from one another in order to avoid vertical social mobility. In this respect the millet system reinforced the maintenance of the existing identities. These ethnic and linguistic attachments had no political significance until the late eighteenth century. However, with the Ottoman transformation in the late eighteenth century, the old ethnic and religious communities began to operate as the basis of nationalities and nations with a corresponding change in group identities. The Ottoman populations did not deny the millet system but redefined that system which laid the grounds for the development of nation-states (Cesur-Baykan 1988, p. 147).

Ethnicity is capable of tuming communities into nations but the key conclusion is that ethnicity does not necessarily yield nationalism. Taking ethnicity as a form of communal organization and as distinct from nations is important. Ethnic struggles can be important but are distinguishable from national struggles.

At this point one should distinguish ethnic movements which claim a separate state from ethnic movements which struggle only for cultural and social rights within an existing nation-state. For example, in multi-ethnic states like Canada and the United States ethnicity has a different dynamic. As Amin points out, in the United States the organised social minorit; groups or cultural ethnic groups claim recognition from the govemment but do not struggle for an independent state (1980, p. 129). In this sense, minority-ethnic groups express resistance to discriminatory practices rather than make claims for independent states or for federation. Multinational states may form the grounds for ethnicity to be viewed in term . of discriminatory practices. 
The second approach to ethnicity views modern ethnicity as a continuation of past ethnic revivals. [9] Here ethnicity again appears as distinguishable from nationalism but, at the same time, ethnic communities can move towards defining themselves as a nation. In this respect, ethnic communities are viewed as self-reproducing cultural entities and in a sense as seeds of potential nations. For example, in Connor's perspective a nation is a self-differentiating ethnic group. Nationhood is a commonly held belief that one's own group is unique in some vital sense and without such a belief there is only an ethnic group (Connor 1972, p. 337).

This perspective sees ethnic communities as the roots of nations. However, not all ethnic communities share the characteristics of a nation. To view one's own group as unique can be possible both at the cultural and political level. In my view the uniqueness of a cultural community must converge with a distinct political identity. In this respect, an ethnic community making political claims appears as distinct from culturally defined ethnic groups. When the state is the target of political claims, such as independence claims, then an ethnic community can be defined as a nation.

However, there is a dual process. In addition to the communal belief of being separate, the acceptance of an ethnic group as a nation by outsiders is equally important in viewing an ethnic group as a nation. This transition can be achieved through the convergence of cultural uniqueness with political consciousness. Thus I claim that political identity is more crucial than cultural identity when separating the proto-nation from an ethnic community. Without a political identity ethnic groups continue to remain simply minority grcips. 
Ethnic communities are always part of a larger nation even if they deny this. Their historical past exists as part of the national history of the ruling nation. Modern states in this sense shape the language of nationalism. and modern ethnic communities cannot be defined without reference to an already existing state. Hence the language of politics, both at the national and supra-national level, is important for the study of any concrete type of nationalism.

Smith's conceptualization of ethnicity is a good example of this second perspective which sees ethnicity as important in the formation of nation-states. In Smith's view, new forms of ethnic revival can only be understood in connection to the previous ones. In this sense, Smith develops an historicist approach to the study of ethnicity. As he stresses, modem ethnic revival assumes a distinctive political ideology which is nationalism (Smith 1981 , p. 5). Moreover, nationalism is the political expression of ethnicity. Smith, in another context, also argues that linking ethnicity and nationalism too closely to modernization creates problems because theories of modemization assume a 'break' with the past. He basically claims that the study of nationalism should move away from the dominant Eurocentric outlook towards nationalism and that it should be firmly attached to the field of ethnic relations (Smith 1983, p. xi).[10]

According to Smith nationalism cannot be analyzed without a theory of the role of ethnic organization and sentiment in history since ethnicity provides a cultural resource for nationalist movements. This approach to ethnicity applies to the Ottoman case. After World War I ended, ethnic communities such as the Turks, Kurds and the Armenians all sought independence from the Ottoman Empire and fought to establish their own states. 
Although the Turks were the last to view themselves as a national community with a distinct political identity, they became the dominating ethnic group during the War of Independence. They established their own independent state while suppressing Kurdish and Armenian claims for political independence. Ethnicity, together with language and religion, has played an important role in the emergence of the nation-states in the Ottoman Empire. In Cesur-Baykan's words, "Smith emphasizes the primacy of the ethnicity. the historically specific social conditions that they have been found. and the nationalist movements over arguments of nationalist ideologies and Western centered explanations of nationalism" (1988, p. 120). Smith's model, which takes into account the communal history of a given country by emphasizing ethnicity, language and religion, proposes a continuity between ethnicity and nationhood which fits well into the Ottoman millet system.

\subsubsection{Conclusion}

Classical Marxist theories of nationalism take the class interests of the bourgeoisie as the sole motive behind the development of nation-states. Modernist theories of nationalism, on the other hand, see industrialization and modemization as the basis of the formation of nation-states. I argue that these accounts of nationalism do not fully explain the problem of nationalism in the Ottoman Empire. The breakdown of the Empire and the emergence of numerous nation-states cannot solely be explained by the diffusion of Westem ideas or as a process of copying the Western model of nation-state. Both internal and extemal factors should be considered. As Kohn argues, “everywhere nationalism differs in 
character according to the specific historic conditions and the peculiar social structure of each country" (1965, p. 89).

A distinction should be made between two forms of nationalism, classical and modem nationalism. Based on this distinction I have looked at the relationship between the nation and the state. The study of nationalism requires an analysis of the process of state formation. In the classical period the nation-states were formed after the establishment of strong centralized states as was the case in Western Europe. During the modern period, on the other hand, the formation of nation-states followed the development of nationalities and nations. For example. Turkish nationalism developed before the emergence of the Turkish nation-state.

However, taking into consideration the model developed by Gellner, the disappearance of the segmented Ottoman Empire and the process of Turkish nation-state building does not radically differ from the Westem pattern with regard to the creation of a culturally homogeneous society. Although Turkish nationalism and its origins differed in character compared to Westem nationalism, the centralized Turkish nation-state aimed at bringing about the unity of 'culture' and 'polity' through forced homogenization as Gellner suggests. At the end, the multi-religious and multi-national Ottoman Empire was transformed into numerous secular nation-states.

At this point it is necessary to emphasize the argument about the process of stateformation in Turkey as 'forced homogenization'. Gellner defines forced homogenization as a process through which the convergence of political and cultural units is attained. I 
argue that forced homogenization was an attempt but it was an incomplete attempt in Turkey. The first phase of this process was the homogenization of the population which was the natural outcome of the breaking apart of the Ottoman Empire. As Davison notes. "only fifty years before the Republic came into existence, the best estimates put the population of the Ottoman Empire at approximately 36,000.000. Of this number. only a little more than one third. or about $13,500,000$ may have been Ottoman Turks...The state which emerged in 1923 was relatively homogeneous. The first census, of 1927, showed a population of only $13.648,270$, but over 90 per cent were Turkish-speaking" (1981, pp. 171-172). During and after the Independence War Turkish state-builders succeeded in absorbing numerous political units which exercised significant claims to sovereignty. Political demands made by ethnic groups such as the Armenians, Greeks of Turkey, and Kurds were all eliminated which constituted part of the process of forced homogenization.

However, if the unity between 'culture' and 'polity' and linguistic-cultural homogeneity are what characterizes the modem nation-state, then the attempt to homogenize Turkish society was not successful as such. Homogenization was more successfully achieved in the cities and among the middle classes. Since there were no modern means of transportation and communication, the daily life in villages did not drastically change with all these developments. Forced homogenization included the creation of national symbols, creation of a unified culture for national cohesiveness, purification of the Turkish language, adoption of Western secular law and of other Western institutional models (such as education, army, and bureaucracy), centralization of education, and the development of the ideology of nation-state. One important aspect of Turkish nationalism 
was the development of the ideology of populism on which the nation-state was built. Gokalp, the outstanding theorist of nation-building in Turkey, considered populism as essential for eliminating social inequalities in the society. Gokalp's ideology of populism "was influenced directly by Durkheim's ideas on the importance of professional ethics in modern society...In modern nations classes are to be abolished and replaced by professional unions cooperating within the framework determined by the social division of labor" (Arjamond 1982, p. 96). In Gokalp's view, populist ideology rests upon the assumption that every individual must be subject to equal rights as they are born into a society. In this respect it necessitates the abolition of economic classes which generates inequality among the constituent members of the society. Consequently, populism means the replacement of economic classes with occupational groups which will bind individuals to one another through ties of solidarity (Hiziroglu-Tokluoglu 1985, pp. 80-82). At a broader level, populism was a protection and an ideological justification against ethnic and cultural tensions and divisions stemming from the past. It aimed at creating a sense of identity on new grounds which was neither economic, nor ethnic-cultural.

All these developments did bring about the unity of 'culture' and 'polity' to a considerable extent but the process of homogenization was nevertheless incomplete since it did not widely diffuse to the periphery. In other words, linguistic, cultural, and religious diversity did continue to prevail in some distant areas. For example, tribalism still was the dominant form of organization in many areas of Eastem Anatolia.

Moreover, for homogenization to be complete, economic relations should also be transformed. As Kohn suggests, uniformity of law and economic life is one essential 
characteristics of the central state (1958. p. 191). Although the new Turkish state granted equality to all subjects and established uniformity of law. uniformity of economic life was partial. As McCarthy notes, the relative place of agriculture in the economy was decreased by war devastation and. due to death and out-migration, the Eastem rural areas did not return to agricultural production after the wars as did the West (1983, p. 145). Small peasant economy prevailed as the dominant form of economy despite the establishment of state-supported enterprises in the provinces. In this respect the nature of the homogenization process is of great concem for a study of state-formation.

To conclude, the relationship between the state and nation is important for analyzing the process of nation-state building. Both Gellner and Anderson emphasize the cultural dimension of nationalism and nation-state building which provides a space for variations when considering the development of non-Western states and nations. I now discuss various theories of state-formation which complement the literature on nation-building and nationalism.

\subsection{Theories of State-Formation}

\subsubsection{Introduction}

The literature on the state covers the formation of states and nation-states on the one hand. and the dynamics of the capitalist state on the other hand. These two areas, too, mostly remain separate from one another. I attempt to bring together both bodies of literature when elaborating on those theories of state-formation which best explain the formation of the Turkish nation-state. I first refer to the peripheral state debate which offers a different 
framework when looking at the state in Third World countries compared to the states in developed capitalist societies. I later focus on three trends that can be identified in the literature on state and state-formation. I present these trends as three different models. and discuss their basic assumptions and the evidence provided by each one of them. I also discuss their validity for the Turkish case which does not fit well into most theories of state-building.

States in the Third World are distinguished from advanced capitalist states on several grounds. Extreme state intervention. the existence of non-democratic political structures, the repressive nature of the bureaucracy, and the nature of capital accumulation all count towards separating advanced capitalist states from the rest. The peripheral state debate, mostly based on Latin American countries, explains these differences within the framework of economic 'dependency' and 'modemization' theory.

This perspective grounds its arguments on the patterns of class formation and class alignment in the peripheral countries which are different from those of advanced capitalist countries. In this context Alavi argues that, "the actual process of class formation and restructuration in Africa. Asia, and Latin America is a consequence of the impact of colonial capitalism...and is quite varied, in accordance with differences in their respective precapitalist social formations, and differences in their encounters with colonialism and the manner of their subsumption under peripheral capitalism" (1982, p. 297). Broadly speaking, according to this perspective, relations of production characterizing the Western countries do not fit into peripheral relations of production. 
Uneven capitalist development and theories of modemization together constitute the comerstones of the peripheral state debate. Peripheral societies are defined as authoritarian regimes due to the modernizing policies implemented by the state. and due to the role of the state in reproducing class domination. Within this framework. as Alavi argues, the analysis of the state is narrowed down to the study of public institutions trying to achieve programs of modernization, to the roles of ruling elites, political parties, the bureaucracy, and the military (1982. p. 289). The peripheral state theory does not take into account the political and ideological factors and the historical origins of authoritarian tendencies. In this sense it is too narrow and economically determinist.

Next I discuss the three different models within the state-building literature and question the fit between these models and the formation of the Turkish nation-state.

The first model includes the Marxist theories in which the state is conceptualized as class based. In this model the needs of capitalism - and of the bourgeoisie - are central to explaining both the formation of nation-states and the dynamics of capitalism. The state is conceptualized as a reflection of the economic relations of production, or as the instrument of a dominant class. Class relations are primary in this model. The second model emphasizes the needs of states. Here the state appears as autonomous from the society compared to the first perspective. Accordingly state activities on the one hand, and social developments on the other hand are two different axes of transfomation intersecting at various levels. The main argument is that state activities cannot be reduced to the economy or to class divisions. The third perspective sees the state as the product of social dynamics. Here the state and the economy are related but both class and non-class 
relationships are involved in the formation of states. In other words, cultural and ideological relationships are as important as economic relations. In this sense statebuilding is related both to economic transformations and, to the previously existing social and political structures and cultural traditions. Thus the state shapes and is shaped by the society.

\subsubsection{Class Based Theorises}

Recent Marxist theories of state have their roots in the works of Marx. Engels, and Lenin. However, it is commonly argued that the classical Marxist perspective on the state is incomplete or inadequate (Carnoy 1984).[11] It is claimed that, for Marx, the state emerges from the relations of production. In this sense the state represents the class structure of given society favouring the interests of the bourgeoisie. The state is reduced to the economic relations of production and the rulers of the state are equated to the bourgeoisie.

In this section I will forgo a detailed discussion of the classical Marxist perspective on the Stah : ather I focus on the more recent Marxist formulations of the state referring to Poulantzas, Anderson, and Wallerstein. In this first model the state is conceived of as class based. The needs of capitalism - and of bourgeoisie - are central to explaining both the formation of nation-states and the dynamics of capitalism. The state is conceptualized as a reflection of the economic relations of production. or as the instrument of a dominant class. Poulantzas, Anderson, and Wallerstein use the (capitalist) mode of production as 
their framework for explaining the state. Their assumptions lay the grounds for a classbased analysis.

For example. Poulantzas, in his The Crisis of the Dictatorships. analyzes the dependent countries (Portugal, Greece, and Spain) in relation to the worldwide process of internationalization of capital and production. He argues that the form of the dependence determines the forms of regimes and the changes in political institutions in dependent countries. Derived from this relationship between metropolitan and dependent countries, he introduces the concept of 'dependent type of state' (Poulantzas 1976. p. 21). The 'dependent state', which can assume different forms depending on the internal factors within these societies, is a form of bourgeois domination.

Although Poulantzas argues that both 'internal' and 'external' factors are equally important when studying a specific country, he limits the internal factors to the changes within the dominant classes and to the modes and forms of production within the context of intemationalization of production and capital.

It is in this context that Poulantzas looks at the relationship between the state and the society. He opposes the idea of viewing the state as a thing or as an instrument of the dominant classes. According to Poulantzas, the state is not a monolithic power bloc free of contradictions. On the contrary, it expresses the class contradictions within a society as internal contradictions. This implies that the state is strictly related to class conflict and struggle. He argues that the state reproduces these class contradictions within itself by its 
very nature as a class state (Poulantzas 1976, p. 82). In short, the state not only refiects the class 'relations' but also contributes to the maintenance of these class relations.

According to Poulantzas, in exceptional bourgeois states (such as in military dictatorships) the ideological role of the military assumes a growing importance. In his view, this shows how a fraction of the state apparatus acquires a relative autonomy of its own in relation to the classes in struggle. This again implies that states reproduce class contradictions and that the state is relatively autonomous from the power bloc (or from a fraction of the pr ver bloc) (Poulantzas 1976).

The state. in this formulation. does not appear as separate from all classes and class contradictions. Although he argues for the relative autonomy of the political from the economic (as in the case of exceptional states), he conceptualizes the social structure strictly in terms of the modes and forms of production. In other words, there is only one kind of struggle in capitalist societies which is class struggle stemming from the relations of production. It can be argued that Poulantzas's argument is reductionist, since the state can be analyzed primarily through class relations.[12]

In contrast, Anderson and Wallerstein assume a strong link between economic change and state-building. Anderson explains historical transformations through different 'modes of production'. His theory originates from the European pattern $r^{f}$ social transformation. However. within the framework of 'Asiatic Mode of Production' debate. Anderson applies his model to other places to explain the derivations from the European model of social change. He looks at the Ottoman Empire arguing that the dominant mode of production 
was the Asiatic mode of production. For him this mode of production provides a shatp contrast with those of the European Absolutism that was contemporary with it. In his words. "The Ottoman Empire remained through its existence on the continent a sixial formation apart...(T) The regulative structure and dynamic of the Turkish State remains of great comparative significance. for the contrast it presents with either variant of European Absolutism. The character of the Ottoman system. moreover. provides the basic explanation of why the Balkan peninsula continued aftel the late mediaeval crisis to evolve in a pattem altogether divergent from that of the rest of Eastem Europe* (Andersin 1974. p. 361).

Anderson sees the complete absence of private property in land as the characteristic of Asiatic mode of production (1974. p. 365). He also attributes a role to the Islamic state structures in determining this specific mode of production. However. he does not take into consideration the social structures and cultura political traditions that influences the form and functionir.g of the state.

Wallerstein, too, offers a theoretical model similar to Anderson's. However, Wallerstein emphasizes the external forces compared to Anderson's emphasis on the internal dynamics when explaining social change. According to Wallerstein, the formation of nation-states can be explained with the development of the world capitalist system. The exchange relationships between the core, semiperipheral, and peripheral societies is the framework for analyzing the dynamics of capitalism. It is also within this context that he separates the strong states of the core from the weak states of the periphery. 
The Absolutist state which developed in the core countries protected the new capitalist economy. In his words, "the absolute monarchy in Western Europe is coordinate in time with the emergence of a European world-economy", and "in the earlier periods of the modern world-system...the states were central economic actors in the European worldeconomy" (Wallerstein 1974, p. 133). In the periphery, on the other hand, the indigenous state is either non-existent or very weak with a low degree of autonomy (Wallerstein 1974. p. 347). The absence of state structures in the periphery is a necessary condition for the reproduction of the role which peripheral cointries play in the world economic system.

Keyder applies Wallerstein's model to the Ottoman Empire when analyzing the integration of the Ottoman economy into the capitalist networks. He argues that the Ottoman integration into the world-market is the most prominent example of non-colonial peripheralisation resembling other cases, such as China and Japan (Keyder 1988, p. 192). Keyder argues that the dynamics of the peripheralisation process can be understood by looking at the conflicting relationship between the bureaucracy and the minorities of the Empire. In his words, "it was the Christian minorities who predominantly assumed the intermediary role between European capital and the, mostly Muslim. producers...Thus.European economic penetration of the realm was seen...by the Muslim bureaucracy to be equivalent to the rise of a Christian comprador class" (Keyder 1988, p. 192). According to Keyder. Turkey lost most of its Christian commercial classes during and after World War 1 , and the first phase of capitalist integration ended with the creation of a native capitalist nucleus. 
At this point it is worth mentioning the peripheral state debate as a variant of the world system theory. According to this framework. imperialism and dependency conditions the process of economic development and political relations in the periphery. The role of the peripheral capitalist state in the process of capital accumulation is the focus of analysis. Consequently class relations and class struggle become primary for understanding the state. Two perspectives are identified within this framework, the 'state capitalist perspective' and the 'bureaucratic-authoritarian' perspective. The former analyzes state policy at the level of economic relations, whereas the latter focuses more on modes of interest representation and social control politics in relation to class interest (Canak 1984. p. 4). This second perspective, developed by O'Donnell, assumes a strong link between economic development and a new political regime based on the authoritarian rule of the bureaucracy which "cludes the classes other than the bourgeoisie from the decision making process. The alliances between the national bourgeoisies and foreign capitalism is the basis of the authoritarian rule in peripheral countries. For the governments shift to orthodox economic policies in order to satisfy the conditions imposed by the multinationals and intemational credit agencies (Zolberg 1987, p. 53).

To sum up, in the 'world-system' model, the state plays a functional role and the worldmarket is the only point of reference. However, state-building cannot be understood primarily in terms of state's contributions to the nascent capitalist economic system. Protection of political interests is equally important in the process of building states (Badie and Bimbaum 1983, p. 72). What is at the center of discussions in this model is the link between economic change and state-building. Hence, there is an implicit 
assumption that societies are either 'modern' or 'traditional' with respect to West European sta.: structures.

I find Stuart Hall's position useful. As he argues, 'economy' and 'state' are not related in a direct way. On the contrary. "the political and ideological frameworks and forces positively mediate the connections between economy and state" (Hall 1984A, p. 27). Stuart Hall's analysis of the rise of the interventionist state in Britain - which takes into account the struggles within the power bloc - offers a framework for studying various 'forms' of capitalist state such as the interventionist or welfare state.

Based on these criticisms it can be argued that the model discussed above would poorly explain those political, cultural, and ideological forces effective in the Turkish stateformation process. The Turkish Revolution did not stem from economic conflicts and struggles and there was no bourgeoisie (or a working class) at the time of the revolution. In this sense it was more a political revolution and it emerged out of the struggles within the ruling elite. Although a national bourgeoisie developed in the aftermath of the revolution, the revolutionaries had no clear economic program until the new regime was established. Thus the dynamic of the state formation process in Turkey cannot be reduced to economic relations of production alone as this model assumes.

\subsubsection{Theorles Emphasizing Crials and State Moeds}

The second model emphasizes the needs of states. By the concept of need I refer to those activities of the state, such as war making, that are necessary for its existence. Here the state appears as autonomous from the society compared to the first model. Accordingly 
state activities on the one hand. and social developments on the other hand appear as two different axes of transformation intersecting at various levels. The main argument is that state activities are irreducible to economy or to class divisions, and international relations and war-making appear as crucial for the analysis of states.

I refer to Tilly, Skocpol, Mann, and Giddens when discussing this second model. As Callinicos points out, Skocpol, Giddens, and Mann argue that the importance of organizations such as states and armies, which are not directly structures of economic power, undermines the explanatory primacy claimed by Marxism for the forces and relations of production (Callinicos 1987, p. 172-173). In this model (referring specifically to Giddens, Mann, and Skocpol), the role of international relations and war is crucial in the analysis of states (Shaw 1989, p. 133). For example, in Mann's perspective, states are above all about military power and national states are "partly, perhaps even largely, products of reorganizations induced by the development of military power relations" (1986, p. 376).

A particularistic approach to the state is inherent in this model.For, as this model suggests, each state should be looked at in relation to a particular society (this also applies to the third model which sees the state as the product of social dynamics). State-making is not seen as the immediate result of capitalist development and as purely economic. As Tilly argues, the European experience of state-making will not repeat itself and this leads one to compare Western Europe with the state-making experience of Eastem Europe, of Asia, and of the contemporary world (1975, p. 12, 17). 
According to Tilly, although there is a reciprocal relationship between capitalism and the growth of state power, this relationship cannot be understood without studying various forms of resistance. Tilly argues that, in Europe, it was not only the people and the traditional authorities (e.g. the landlords) who resisted state expansion. The capitalists themselves, too, often had to fight off state power. It is within this context that Tilly associates the formation of states with the process of cultural homogenization. If statemaking means absorbing numerous political units which already exercise significant claims to sovereignty then cultural homogenization becomes essential for two reasons. First a culturally homogeneous population lowers the cost of state-making by making uniform administrative arrangements feasible. Second it contributes to the early development of nationalistic ideologies which affects the process of becoming a unitary and an autonomous state (Tilly 1975, p. 42, 43).

Tilly claims that the tolerance for linguistic, cultural, and religious diversity stands in the way of effective state-making. The failure to homogenize will cause the fragmentation of any state into its cultural sub-divisions in the future. This argument fits into the Ottoman case which was fragmented into its constituent religious-ethnic communities. However, the Ottoman rule for six hundred years can also be regarded as a success which can be explained by the Ottoman success in wars. For, as Tilly claims, success in war is one of the six conditions for explaining state-making (1975, p. 40). Tilly continues his argument by claiming that wars have shaped the European state system as a whole, and he refers to the breakup of the Ottoman and Austro-Hungarian Empires as examples for his argument. 
In short, for Tilly, both the international context (in terms of wars among states) and the particular context (in terms of resistance to the creation of strong states and a move toward homogeneity within states) play important roles in the formation of states. In this respect forms of resistance and the nature of the homogenization process are of great concern for a study of state-formation. As Badie and Bimbaum argue, the rise of the state is related to the way in which traditional society breaks down (1983. p. 68).

Compared to Tilly's model, Skocpol argues for a more state-centered approach. As opposed to the first model (class-based theories), she claims that political revolutions do not necessarily stem from class conflict (Skocpol 1978. p. 4). Social revolutions, for her. are direct expressions of crises centered in the structures of old-regime state (Skocpol 1978, p. 29).

Trimberger's analysis of the Turkish Revolution supports this state-centered approach. According to Trimberger, the Turkish state was formed by an autonomous bureaucratic class who had no control over the means of production, and that the state and military bureaucrats were not merely an instrument of a dominant economic class (1978, p. 4). She presents the Turkish case as an extraordinary instance of state autonomy where the state was used - by autconomous bureaucrats - to change the whole fabric of the Turkish society and politics. As she argues, the state apparatus is separate from the dominant classes in the Turkish case. Hence, in arguing against. Trimberger claims that it is essential to distinguish between class power and state power (1978, p. 7). 
It is at this point that Skocpol calls attention to the debate on state autonomy. She argues that, in welfare-states such as Sweden and the United States, it is possible to see the autonomous power of the state where civil service administrators can actually implement policies of their own and contribute to social policy development. As she puts it. "The point is that policies different from those demanded by societal actors will be produced. The most basic research task for those interested in state autonomy surely is to explore why, when, and how such distinctive policies are fashioned by states" (Skocpol 1985. p. 15). For Skocpol. the conflicts of interest between the existing dominant class and the state rulers is essential for grasping the dynamics of the periods of crisis.

Giddens and Mann challenge the idea that societies are bounded and unitary. According to Jessop, both Giddens and Mann argue that the expansion of the international state system was heavily influenced by military organization and the impact of wars, and that international relations were dominated by trade, diplomacy and warfare (1989, pp. 118119).

In Mann's view, the dynamic of state formation in Europe was not purely economic. Ideological, military, and political power relations were also involved in the process of making states. What is implicit in Mann's model is that the Western world has its own structures and dynamics and non-Westem states cannot be analyzed through power networks specific to Westem societies. Within this framework Mann challenges the comparative approaches fostering the separation between Western and non-Western societies based on such criteria as patrimonialism and rationalism. For him, on the contrary, "it is the dialectic between the centralizing and decentralizing that provides a 
considerable part of social development. and this has been especially pronounced in the history of the Near Eastern Wediterranean Western world" (Mann 1986, pp. 172-17.3).

Mann separates class struggle from the struggle for state control. He also argues that conflicts between classes and other 'civil society' groups constitute another level of struggle which is equally capable of mobilizing broader populations; In this context he refers to religious struggles which are not directed at the state and which cannot be reduced to class struggle. In arguing against Poulantzas, Mann claims that class struggles during the period of territorial state formation were resolved without much state regulation: "The state may have been a factor in social cohesion, but is was hardly the factor" (1986, p. 434).

In short, in Mann's view, state functions are mostly military and geopolitical rather than economic and domestic. Along with Tilly and Skocpol, Mann argues that the outcome of class struggle is determined by the nature and interrelations of the states. In this sense class and state struggles are interconnected (Mann 1986, p. 513).

Similarly, in arguing against Marxism, Giddens criticizes those theories which overemphasize the role of the state in economic life (1985, p. 28). He also criticizes theorists of international relations who, in Giddens's view, treat the state as an actor hence underestimate the significance of internal struggles (1985. p. 288). However, Giddens himself offers a state-centered approach by stressing the importance of militaryadministrative control, warfare, and international relations in the functioning of nationstates. 
This second model, by rejecting any direct link between state formation and economic changes, presents an alternative approach for studying the formation of states compared to the first model. Both the international context and the specific historical circumstances of a given country become important in the analysis of states. The emphasis on the relative autonomy of the state and on the role of war in the making of states does apply to the Turkish experience of state building. The bureaucratic class which led the Turkish Revolution does confirm the assumption that states are autonomous entities. Also previous military defeats and the invasion of Turkey after World War I are part of the dynamic which gave rise to the establishment of a new state regime in Turkey. For the Turkish Revolution (1919-1923) was, at the same time, a war of national independence.

However, in this model state autonomy is regarded as a permanent fact. Hence, the state stands outside and above the society. Following Mann, it can be argued that the power autonomy of states is rot a constant (Mann 1986. p. 514). Going one step further it can be questioned whether the Turkish bureaucrats had absolute power autonomy during the formative years of the state. The bureaucracy, which was at the core of the state, faced considerable resistance and fought for ideological and cultural legitimation in the process of building the new Turkish nation-state.

In short this model sets the parameters for analyzing the state-formation process in Turkey. However, the autonomy of the state and the role of the military are overemphasized. 


\subsubsection{State as the Product of the Social Dynamics}

The third perspective conceptualizes the state as the product of social dynamics. Here the state and the economy are related but both class and non-class relationships are involved in the formation of states. In other words. cultural and ideological relationships are equally important as economic relationships. In this sense state-building is related both to economic transformations and to social and political structures and cultural traditions.

The concepts offered here challenge some of the basic assumptions discussed above (such as arguing for a direct relationship between state and economy). In this model I refer to Gramsci. Cortigan, and Elias. They all present a different vision by conceptualizing the state's unity as constituted politically, culturally, and ideologically. In this sense. compared to the first two models, there is a dynamic relationship between the state and society. Such dualisms as coercion and consent, resistance and support. public and private are treated as essential in rejecting economic determinism.

To begin with, I first consider Gramsci's conceptualization of state and state power. The Gramscian approach to the state is not restricted to the forms and modes of production. Gramsci's work proposes the idea that the state cannot be understood without a thorough understanding of 'civil society', where civil society is defined so as to include all the private organizations such as churches, trade unions, political parties and cultural associations which are distinct from the process of production and from the apparatuses of the state (Simon 1982. pp. 68-69). In Gramsci's words.

What we can do, for the moment, is to fix two major superstructural 'levels': the one that can be called 'civil society', that is the ensemble of organisms commonly 
called 'private', and that of 'political society' or 'the State'. These two levels correspond on the one hand to the function of 'hegemony' which the dominant group exercises throughout society and on the other hand to that of 'direct domination' or command exercised through the State and 'juridical' government (1973, p. 12).

In this respect. according to Gramsci's formulation. the state and civil society do not refer to two different and separate areas since they are both composed of social relationships that reflect the relations of power within society. Hence. "the power of the state is therefore as importantly cultural and ideological as it is coercive" (Urry 1981, p. 22). In other words, the power of the state cannot be grasped only through economic relations of domination. Based on this formulation, Gramsci examines the roots of state power within the economy and civil society. As Gramsci argues,

the most reasonable and concrete thing that can be said about the ethical State, the cultural State, is this: every State is ethical in as much as one of its most important functions is to raise the great mass of the population to a particular cultural and moral level, a level (or type) which corresponds to the needs of the productive forces for development, and hence to the interests of the ruling classes. The school as a positive educative function. and the courts as a repressive and negative educative function, are the most important State activities in this sense: but, in reality, a multitude of other so-called private initiatives and activities tend to the same end - initiatives and activities which form the apparatus of the political and cultural hegemony of the ruling classes (1973, p. 258).

In this context, Gramsci analyzes state power in terms of both coercion and consent (or force and hegemony) which are two different modes of class domination. Force and hegemony explain the dominance of the ruling class, both associated with the maintenance of the state in capitalist societies.

Uny claims that. Gramsci does not consider the heterogeneity of social practices within the civil society. and that he analyzes only those that contribute to the establishment of 
hegemony - excluding the practices that relate to the more personal and spontaneous forms of human activity (Limy 1981. p. 24). It is at this point that Corrigan. Kamsay. and Sayer argue that state formation and moral regulation are internally related. For state regulation necessitates a prior categorization of human beings - based on gender. age. class. and so on (Corrigan. et al 1980, p. 10). Also. Corrigan claims that state intervention at the level of cultural relationships can be observed through the regulations concerning age. family, inheritance, or dress (Corrigan 1980, p. 32).[13]

This link between state and cultural relations can be seen as the basis of an argument that states operate not only through coercive means, but also culturally and politically. What follows from this argument is that states are 'constructed' through extensive struggles. Elias's theory of state, which sees the transformation of both the personality structure and the entire social structure as part of the state formation process, further contributes to this perspective (Elias 1982).

It is in this context that 'resistance' to state formation becomes an essential dimension of this third model. Corrigan argues that it is imponant to consider both the alternative national groupings or other state systems, and the pressure from within the single social formation when theorizing the process of state formation (1980, p. 29). Jessop's argument supplements this position. According to Jessop. both 'suppon for' and 'resistance to' hegemonic projects are important for an adequate understanding of the state. Also, the groups involved in support and resistance do not necessarily have a class belonging (Jessop 1982, p. 246). In short, what follows from this is that, states are 'constructed' through extensive struggles which involves popular relations and forces as well. 
The mobilization of support and resistance cannot be restricted to economic relations alone. At this point I refer to Flias's theory of state where state formation is discussed in relation to the 'civilizing process' which took place in the Western world. The framework within which: Elias discusses state formation differs from most of the frameworks discussed above. For example, he argues for a strong link between state formation and the transformation of the personality structure. In this sense both Corrigan and Elias share the view that state and society are inseparable. Further they share the view that tensions and struggles are an integral part of the state formation process affecting the direction of change.

Elias provides a detailed analysis of the power struggles between the nobility, the Church. the princes. and the bourgeoisie within the European countries. He relates the formation of states to the monopolization and centralization of taxes and physical force. Within this framework he discusses the changing roles of the powerful classes in relation to the distribution of social power among different strata which, as he argues, was highly complex. At this point l elaborate on Elias's concept of 'civilization' and discuss its contribution to the framework outlined above.

According to Elias state formation is firmly linked to the process of 'civilization'. He defines the 'civilizing process' as a change in human conduct and sentiment in a quite specific direction which is not the result of purposive human behaviour (Elias 1982, p. 229). Civilization reflects the changes in the structure of human relations which corresponds to changes in the structure of the personality. These processes, in turn, result from the process of differentiation of social functions. As Bezucha points out, "Norbert 
Elias has brilliantly demonstrated that there is a fundamental relationship between the distribution of power in society and the development [processus] of civilization" (1976. p. 176).

For Elias the movement of society and civilization does not follow a straight line. There are always counter-movements in which the tensions of society comes to the surtace. This is especially true for the 'spread of civilization' beyond the West. The spread of Western 'civilized' partems of conduct (including science. technology. and other manifestations of a specific type of self-restraint), is not a smooth process. As Elias puts it. "here. too, the transformation of the whole of social existence is the basic condition of the civilization of conduct" (1982. p. 254). However, as Elias's perspective implies, the confrontation of the pre-existing forms of civilization with the Westem civilizing movement creates deeper tensions.

As Elias argues. the whole civilizing process takes place inconstant conjunction with the struggles of different social strata and other groupings. For him. "tensions and struggles as much as the mutual dependencies of people - are an integral part of its (the civilizing process) structure: they decisively affect the direction in which it changes. Undoubtedly. a civilizing movement can take on considerable importance as a weapon in these struggles" (Elias 1982, p. 283).

Elias's perspective provides a large space for studying struggles other than economic ones. He extends the definition of power struggles in such a way as to include any type of relationship between different strata. Thus there are many different 'axes of tension', as 
Elias formulates it, and the basic ones can be identified which affect the direction of change in the formation of states.

Corrigan and Sayer's study of the English State formation resembles Elias's approach to state formation. They arque that. "the triumph of modem capitalist civilization involved a wholesale cultural revolution too" (Corrigan and Sayer 1985, p. 1). The relation between state formation and cultural revolution can be seen simultaneously through the cultural content of state institutions and through the state regulation of cultural forms. In this sense. states regulate cultural relations and, this "moral regulation is coextensive with state formation" (Corrigan and Sayer 1985, p. 4).

To summarize, this third model provides a broader framework for looking at the process of nation-state formation. Also it can be applied to states other than European ones for this perspective denies the validity of any grand theory of state formation suggesting a universal pattern for the development and functioning of states. In this respect, states formed by a bureaucratic class such as Turkey may well be analyzed through the concepts provided by this model. More importantly, this last model provides the grcunds for linking state-building to forms of resistance against state-makers or against state authority in general. For, in this model, tensions and power struggles between different social groups. which may or may not have a class characteristic, are seen as part of statebuilding dynamic which can be curved out through detailed historical analysis.

Also the emphasis on moral regulation as internally related to state formation can help to explain the role of secular nationalism and Westernization which were part of the state- 
building dynamic in Turkey. For example. Ataturk's hat reform and the restriction on the wearing of the veil as part of the modemizing project are examples of state concern at the level of cultural relationships which. in the Turkish case. supports the basic assumptions of this model.

What follows is a discussion of the fit between these models and the Turkish statc at a broader level pointing out some of the silences and gaps within the literature.

\subsubsection{Conclusion}

I outlined the basic approaches within the state-formation literature in relation to the basic characteristics of the Turkish state-building experience. The Turkish state has mosily been studied wirhin the framework of 'world system' or 'peripheral state' theory where capitalismindustrialism and the bureaucracy have been the core concepts. Consequently. capitalist integration and modernization-Westernization as the program of the bureaucratic class have been the principal parameters for arilyzing the Turkish state. The existence of an autonomous bureaucratic class is mostly treated as a point of departure in contrasting core societies with peripheral ones. This perspective denies the variations in state forms within cor: and peripheral states.

The second and third models discussed ajove do not place nation-states in pre-given categories disregarding their specific features. The second model, which emphasizes the geo-political relations between states, presents a view of history from above. According to this model, transnational relations contribute to the formation of states and shape the internal struggles. The third model, on the contrary, emphasizes the significance of 
intermal struggles which is missing in the second model. Internal struggles influence external policies both of which are important in the formation of states. In this respect the two models are complementary. Also the second and the third models consider non-class movements - such as national, religious, and ethnic struggles - as an ir ezral part of the state-formation process whereas in the first model the role of these movements is ultimately epiphenomenal.

The Turkish state was formed on the basis of the Western model of nation-state. Hence, despite the fact that it was formed by the bureaucrats, it can be argued that the Turkish state does not fall into a totally different category. At this point I draw upon Giddens who broadly groups the nation-states into types in terms of divergent modes of original state formation. He groups the nation-states into four: classical (the European nation-state). colonized, post-colonial, and modernizing (Giddens 1985, p. 269). He argues that,

linguistic uniformity linked to a degree of cultural homogeneity can rightly be seen to be distinctive characteristics of the classical nation-state... Not all nation-states that can be placed in the classical type were established in the eighteenth and nineteenth centuries. Those set up in Europe and around the margins of Europe rollowing the World Wars (including ex-imperial states like Austria or Turkey) belong in this category. Some states established earlier, on the other hand, belong rather in the modemizing type (eg. Germany) (Giddens 1985, p. 270).

Supported by this classification the Turkish state's specific characteristics can be linked not only to the level of its economic development (and to the role of bureaucracy) but to the internal struggles within Turkey in the formative years of the state. Also the place occupied by the Ottoman Empire within the international state system during that specific period cannot be neglected due to the reciprocal influence between internal and external factors. However, state formation considered 'from below' (as the third model suggests) 
is the most promising model for an adequate study of the internal dynamics that led to the establishment of the Turkish nation-state.

The development of the Turkish state does not fit well into most theories of stateformation when the role of the bureaucracy is overemphasized. This problem may well be seen as stemming not simply from the nature of the Turkish state as a unique case but from the gap: within the state-building literature. As Zolberg puts it. “a partıcularly interesting question concerns the role of the dynamics of world capitalism in the emergence of European versions of 'bureaucratic authoritarianism' in the interwar period"* (1987. p. 54). The development of interventionist states and of welfare states in the postwar period challenges the categorization of nation-states according to the role played by the bureaucracy in the formation and functioning of states.

It may be argued that the distinctive nature of the Turkish case stems from the characteristics of the ideological and cultural struggles that occurred within the process of establishing a modern centralized state. In this context the autonomy of the bureaucratic class may not be the starting point but can be treated as one essential element in the dynamic of state-formation. Hence 'state forms' rather than an abstract model for the state' needs to be considered as suggested by the second and the third models. The form of the Turkish state was basically the West European one but the path of development was, however, divergent and distinct from that of the West European states. 
At this point I refer to Stuart Hall's argument concerning the routes which states may

follow when ruling in modern society. Here I refer to the first two routes. According to Stuart Hall,

(i) The state can invoke the long. customary and traditional way in which this state has, in fact, ruled in the past. (ii) In times of extreme danger to or difficulty for the state, some person or group or force with exceptional or charismatic qualities may acquire the legitimacy to assume exceptional powers in the state: dictators, military leaders, leaders of popular movements which toppled the previous regime. wartime prime ministers, etc. (1984B, p. 16).

These definitions of state rule as two different routes both fit the Turkish case. The Ottoman tradition of state rule was influential in the formation of the Turkish state. Also the external and internal dangers for the Ottoman state were an important factor in the rise of the military-bureaucratic class with exceptional powers to rule. In this respect, the Turkish state, although formed by the bureaucracy, may not be conceptualized as a deviation from the West European pattern, but as a case which followed a different path in the establishment of the nation-state. I discuss the basic features of the Turkish state in Chapter Three.

\subsection{Theorles of Resistance Versus State-Formation}

\subsubsection{Introduction}

I focus on the literature on political resistance or opposition (mostly pre-capitalist forms of resistance). To conceptualize resistance and to distinguish various forms of resistance which do not lead to visible or immediate political transformation is essential for the purpose of this essay. In this context I map out those different approaches to the study of resistance. 
In other words, with regard to Turkey. I intend to identify the absence or presence of those forms of resistance experienced in Europe in the past. On this basis 1 discuss the importance and the consequences of resistance for the state building process in Turkey in order to give an explanation of why these particular forms of resistance occurred rather than other forms.

\subsubsection{Theoretical Approsches to Resistance}

I use the term 'resistance' to differentiate between the terms 'resistance', 'organized political opposition', and 'revolution'. As Tilly notes, revolutions should be distinguished from insurrections, rebellions, revolts, coups, and wars of independence (1978. p. 193). Movements of resistance may not have immediate visible consequences as do revolutions or wars of independence. In this context it is important to discuss what constitutes resistance, and its relation to state or to class domination.

Several 'modern' and 'pre-modern' forms of protest movements can be identified.

Organized modern protest movements include modern trade unionism, strikes, elections, and demonstrations. Pre-modern forms of protest, on the other hand. consist of a wide variety of altematives as means of resisting situations regarded as unjust. These include food riots, tax revolts, machine breaking, lynching, village fights, brigandage, banditry, and local actions against soldiers, landlords, and merchants. I focus on those theories which lay the ground for considering these pre-modern forms of protest as part of the state-building dynamic because the types of resistance experienced in Turkey, which is the focus of this study, fall within this category. 
I first refer to Moore and Wolf who represent the Marxist perspective with regard to peasant wars and revolutionary transformations. The perspective relies on class analysis. The expansion of capitalism and the growth of the state are tied together, and collective interests are based on material interests. For example, although Wolf stresses the importance of the local and regional (traditional) differences which divides the peasant class, he basically gives priority to the expansion of national and intemational markets (Wolf 1969. p. xii, xiv-xv).

Moore, too, regards the development of market economy and of class difference as primary. Consequently, he focuses on the process through which the commercial and industrial leaders become the dominant element in society. According to Moore, cultural differences are not sufficient to explain differences in economic behaviour (1974, pp. 485 486). [14] What counts is the class coalitions involved in revolutions.

This perspective provided by Moore and Wolf excludes most of the issues discussed above such as non-economic power struggles, various forms of local resistance against state or class domination, and local protest movements. Hence it offers little room for analyzing non-revolutionary transformation since the consequences of collective interests other than economic ones are not considered as important.

Scott refers to the growing dissatisfaction with this trend. He argues that, "peasant rebellions, let alone peasant 'revolutions', are few and far between. Not only are the circumstances that favour large-scale peasant uprisings comparatively rare, but when they do appear the revolts that develop are nearly always crushed unceremoniously" (Scott 
1985. p. 29). In this respect, he argues that, it is "far more important to understand what we might call everyday forms of peasant resistance - the prosaic but constant struggle between the peasantry and those who seek to extract labour, food, taxes, rents, and interest from them" (Scott 1985, p. 29). These forms of resistance require little coordination and they avoid any direct symbolic confrontation with authority or with elite norms.

Scott contrasts 'everyday' resistance with 'institutionalized' politics. He argues that while the former is informal, often covert, and concerned with immediate gains, the latter is formal. overt, and concerned with systemic change. For him, military desertions fall somewhere in between. Military desertions aim at self-help rather than institutional confrontation. However, the massive withdrawal of compliance has radical implications for the army as an institution (Scott 1985, p. 32). At this point Scott attacks the existing concepts of resistance. I quote at length for I find his conceptualization of resistance very promising.

The problem with existing concepts of resistance is therefore not that they must inevitably deal with intentions and meaning as well as with consequences. Rather, the problem lies in what is a mislcading...insistence upon distinguishing 'selfindulgent', individual acts, on the one hand, from presumably 'principled'. selfless, collective actions, on the other, and excluding the former from the category of real resistance. To insist on such distinctions as a means of comparing forms of resistance and their consequences is one thing, but to use them as the basic criteria to determine what constitutes resistance is to miss the very wellsprings of peasant politics...It is precisely the fusion of self-interest and resistance that is the vital force animating the resistance of peasants and proletarians... When a peasant soldier deserts the army because the food is bad and his crops at home are ripe, he is both looking after himself and denying the state cannon fodder. When such acts are rare and isolated, they are of little interest: but when they become a consistent pattem (even though uncoordinated. let alone organized) we are dealing with resistance (Scott 1985, pp. 295-296). 
Social tanditry, too, falls into the same category. As Scott states, "the peasantry is best suited to extended guerrilla-style campaigns of attrition that require little or no coordination" (1985. p. 35). Hobsbawm's analysis of social banditry supports this position.

Hobsbawm analyzes not only social bandits (both peasant and urban forms of banditry). but also the mafia and millenarian movements as types of pre-modern protest movements. For him social banditry and mafia are nonrevolutionary types of protest. Millenarian novements, on the other hand, are more revolutionary compared to the first two types for they are more easily absorbed into modem social movements (Hobsbawn 1959, pp. 5-6).

According to Hobsbawm, social banditry, which is a widespread social phenomenon, is a form of individual or minority rebellion within peasant societies. It lies between the evolutionary phase of tribal and kinship organization, and modern capitalism and industrial society (Hobsbawm1969, p. 14). As Hobsbawm defines them, social bandits are peasant outlaws who, nevertheless, remain within peasant society. Bandits resist the rich, foreign conquerors, and any other force destroying the traditional order of things without having a programme for peasant society. They fight for justice not as revolutionaries but as reformers. Banditry has a limited revolutionary potential since, in normal times, it operates within the existing social and political structure or on its margins, rather than against it (Hobsbawm 1969, p. 92).[15]

Hobsbawm identifies three forms of social banditry, the noble robber (Robin Hood), haiduks (prinitive resistance fighter or guerrila unit), and terror-bringing avenger (1969. 
p. 15). The Robin Hood type of banditry is the most popular and universal form of banditry. Robin Hoods 'right wrongs'. and they fight for justice and social equality. There is total solidarity between the Robin Hoods and the peasants (Hobsbawm 1969. pp. 3435). The avengers, on the other hand. do not appear as men who right wrongs, but as exerters of power. In Hobsbawm's words. "their appeal is not that of the agents of justice. but of men who prove that even the poor and weak can be terrible" (1969, p. 50).

Among these three forms of social banditry. 'haiduks' have a relevance for the purpose of this study.[16] The Ottoman Empire had a bandit problem which was never solved by the central authority. In this respect, it is important to stress some of the characteristic features of 'haiduks' which resemble the bandits of Turkey. As Hobsbawm defines them. the haiduk banditry was a more permanent and institutionalized challenge to official authority than the Robin Hoods which emerged from any normal peasant society. In this sense the 'haiduk' was a political hero. They existed in Russia. Greece. Ukraine, Hungary. and in the Balkan peninsula. Especially in the Balkans the 'haiduk' was a national bandit defending the Christians against the Turks. The bandits in the Balkans took part in the Balkan Wars of the 1870 s against the Ottoman Empire, which reflects the fact that bandits can become national liberation bandits under certain circumstances, such as foreign conquest.

In general, unlike the Robin Hoods and avengers, haiduks were not committed to rebellion against all authority. As Hobsbawm notes, “they could, as in some parts of Hungary, become attached to lords whom they provided with fighters against a recognition of their status as free men" (1969. p. 6:). Hobsbawm defines haiduk banditry 
as the highest form of primitive banditry and as the one that comes closest to being a permanent and conscious focus of peasant insurrection. In this sense. haiduks were different from Robin Hoods, and they were more permanently cut off from the peasantry than the classical social bandit. Haiduk banditry is defined in political terms since it is a more permanent and formalized challenge to official authority than Robin Hoods (Hobsbawm 1969, pp. 62-66). Generally, banditry is one aspect of peasant movements which is capable of mobilizing the peasantry. In case of national liberation movements bandits can easily become part of the movement as was the case in Turkey. Although Robin Hood type of banditry existed in the Ottoman society, it can be argued that haidukdom better characterizes the form of peasant resistance in Oroman society. I discuss these issues in more detail in Chapters Four and Five.

Hobsbawm also considers 'mafia' which he regards as an embryo of a subsequent national movement (1959, p. 9). Masonic groups, too, had the potential of turning higher groups into political centers. As Hobsbawm claims, during the American and French Revolutions, and also in Ireland masons were prominent (1959, p. 163). The Committees of Union and Progress, which I discuss in Chapter Three, were masonic-type organizations. They had nationalistic aims as Hobsbawm suggests. Lastly, Hobsbawm refers to millenarian movements which were absorbed by nationalist, socialist, communist, and anarchist movements. Millenarian movements were revolutionary for they had an ideology which was based on a desire to change the world for a better one (Hobsbawm 1959. pp. 57-59). 
The nature and form of peasant involvement in protest movements may change from time to time and from one place to another.[17] Peasants may resist increasing taxation. military exactions, or 'officeholders' exactions. For example, war making and military exactions may initiate protest among peasants against national authorities as well as against landlords. Under such circumstances, as Tilly points out. locial power holders may ally with rebellious peasants (1981. p. 114). This holds for the Turkish case where l(xill power holders mobilized the tribes and some segments of the rural population and revolted against national authorities. Again under such circumstances desertion, and attacks on officeholders and soldiers becomes an effective means of resistance against national authorities, which was again the case in Turkey. Thus the struggle between the peasants and landlonds is not the only form of struggle. A coalition of landlords and peasants against state officials or capitalists is another possible form of struggle (Tilly 1981. p. 139).

In general, social banditry, military desertion, and other forms of resistance such as attacks on officeholders are common expressions of protest not only to powerful states but also to the process of state-making. The rise of national states threatened local power holders involved in small-scale politics which initiated resistance from bandits, religious communities, national minorities, or from uncompromising separatists. In order to succeed state-makers had to set up armies (often by incorporating irregular local forces into the national forces), increase taxes, suppress protest movements, and expand the number of groups that are involved in state activity. 
Tilly also argues that a revolutionary situation begins when a government under the control of a sovereign polity becomes the object of mutually exclusive claims on the part of two or more distinct polities. Multiplication of polities creates a type of conflict which can be seen as a special variety of war (Tilly 1978, p. 191). This, again. was the case during the National Independence War in Turkey. There were two governments claiming sovereignty, the Sultan's government in Istanbul and the nationalist government in Ankara, both of which were recognized and even invited to the peace conference at Lausanne by the Allied powers. This situation in Turkey fits into what Tilly calls 'multiple sovereignty' which marks the beginning of a revolutionary movement. Tilly also stresses the role of the military in a revolutionary situation and refers to Egypt and Turkey as two extreme cases. In his words. "the Egyptian and Turkish revolutions stand near the extreme at which the chief claims to alternative control of the government came from within the military itself; in both cases soldiers dominated a coalition linking dissident politicians and local movements of resistance" (Tilly 1978. p. 201).[18]

At a more general level, I now consider the relationship between movements of resistance and political-cultural transformations. As Corrigan argues. cultural relations can be located and analyzed within the history and understanding of 'struggle' (1988, p. 46). Resistance to state-making is not a revolutionary situation but may have a significant impact on the nature and form of the process of state-making and its outcome. In this sense its symbolic significance appears to be important for understanding the nature of conflicts in any phase of state-making process. 
Official and cultural institutions are the producss of not only political and economic struggles but of cultural struggles (over meanings or over competing world viturs) as well. Here I refer to Mullett. His ana!ysis of popular protest in Western Europe fixuses on popular culture. For him. popular protest (such as revolt. rebellions, banditry. and murder) is influenced by the language and assumptions of popular culture. The language of peasant revolts was formed by the collective rituals and religious symbols used by the villagers rather than the language of the outsider agitator (Mullett 1987. pp. 71). In this sense, popular culture provides legitimation to popular protest. However, it also shapes the patterns of protest.

In addition to the point discussed above. Mullett also analyzes the interaction between elite culture and popular culture, using the term 'culture' in its broadest sense. Although the culture of the lower strata was subject to change as a result of its interaction with elite culture. it did not disappear but gave way to a new pos sular culture. What can be inferred from this position is that the struggle between the two cultures is a manifestation of the struggle over religion, politics, and 'ways of life'.

Scott's argument further supports this perspective. According to him. "where everyday resistance most strikingly departs from other forms of resistance is in its implicit disavowal of public and symbolic goals" (Scott 1985. p. 33). Everyday resistance is reinforced by a populur culture of resistance. Hence, "the symbols, the norms, the ideological forms they create constitute the indispensable background to their behaviour" (Scott 1985, p. 38). In this respect, the meaning resisters give to their acts coristitutes an important dimension of any study attempting to analyze various forms of resistance (o) 
state authority. Thus, as Scott claims, "by reference to the culture that peasants fashion from their experience - their 'offstage' comments and conversatior, their proverbs, folksongs, and history, legends, jokes, language, ritual, and religion - it should be possible to determine to what degree, and in what ways, peasants actually accept the social order propagated by elites" (1985, p. 41).

From these arguments it can be concluded that non-revolutionary protests, which does not lead to immediate political transformation, need to be analyzed with a focus on their symbolic significance. In this context I refer to Foucault, who provides a framework for looking at various forms of domination which do not have a clear class base.

Foucault's conceptualization of power is a diffused one. As he argues, it is not an institution or a structure, but it is the name that one attributes to a complex strategical situation in a particular society (Foucault 1980B, p. 93). As he argues. "the analysis of power relations within a society cannor be reduced to the study of a series of institutions, not even to the study of all those institutions which would merit the name 'political'. Power relations are rooted in the system of social networks" (Foucault 1982, p. 224).[19] Foucault's conceptualization of power is related to his conceptualization of resistance. The dominators and the dominated are related through resistance, and resistance is never exterior to power. In other words, there are always various forms of resistance against different forms of power which brings these power relations to light. In his own words, "rather than analyzing power from the point of view of its internal rationality, it consists of analyzing power relations through the antagonism of strategies" (Foucault 1982, p. 211). 
In Foucault's view, resistance does not always produce great transformations and revolutions. However, resistance has mobile and transitory points which produces cleavages in a society, fractures unities and effects regroupings which makes a revolution possible (Foucault 1980B, p. 96). In this context. Foucault's concept of 'subjugated knowledge' should be mentioned. 'Subjugated knowledges' are those blocs of historical knowledge which were present but disguised within the body of systematising theory (Foucault 1980A, p. 82). This knowledge is particular, local, and regional suggesting that there are subject positions. What this implies is that a population's historical past can always be reconstructed on the basis of local popular knowledges (or subjugated voices) which may give rise to the development of ethnic and religious ideologies capable of mobilizing certain groups.

I also find Bourdieu's analysis of the 'relations of domination' and their reproduction useful. He looks at the mechanisms which set up and conceal lasting relations of domination. In Bourdieu's words,

once a system of mechanisms has been constituted capable of objectively ensuring the reproduction of the established order by its own motion...the dominant class have only to 'let the system they dominate take its own course' in order to exercise their domination; but until such a system exists, they have to work directly, daily, personally, to produce and reproduce conditions of domination which are even then never entirely trustworthy...they are obliged to resort to 'the elementary forms of domination', in other words, the direct domination of one person by another (1977, p. 190).

According to Bourdieu there are two forms of violence under this system discussed above, overt violence and symbolic violence. These two forms of violence coexist in the same social formation when domination can only be exercised in its 'elementary form'. As an 
example he refers to the pre-capitalist economy where both forms of violence coexist.

Pre-capitalist economies need symbolic violence for it is the only way in which relations of domination can be set up. In other words, if relations of domination are not disguised they destroy themselves by revealing their true nature. As Bourdieu claims, the precapitalist economy "resorts 'simultaneously' to forms of domination which may strike the modem observer as more brutal, more primitive, more barbarcus, or at the same time, as gentler, more humane, more respectful of persons" (Bourdieu 1977. p. 191). The exercise of these two forms of violence for the establishment of a domination relation is the basis of ...y kind of power struggle in pre-capitalist societies, and it fits well into the Turkish case with regard to the forms of violence - such as the hat reform or public hanging exercised during the formative years of the state-building process. The forms of resistance provoked by various forms of domination relations can reveal the ways through which state power was exercised in Turkish society during the establishment of the new state.

\subsubsection{Conclusion}

Resistance to state-building, which can be characterized as a process of forced homogenization of society, is a characteristic of all nation-state building experiences, and Turkey is no exception. However, various forms of resistance and opposition experienced in Turkey were mostly not institutional and formally organized forms of opposition. In this sense they were basically less developed compared to the ones experienced in Western European countries. There were no organized labour or peasant movements capab! of implementing the desired policy changes. However, as Scott states, "if we 
were to confine our search for peasant resistance to formally organized activity. we would search largely in vain. for in Malaysia as in many other Third World countries. such organizations are either absent or the creations of officials and rural elites. We would simply miss much of what is happening' (1985, p. 298).

Tilly divides collective action into three varieties, competitive actions, reactive collective actions, and proactive collective actions. For him, in Europe, in the fifteenth and sixteenth centuries competitive actions constituted the dominant form. From the seventeenth to the nineteenth century, the reactive forms became much more widespread such as food riots. machine breaking, tax rebellions, and local actions against the military conscription. In the nineteenth and twentieth centuries, collective proaction (such as the strike for higher wages) replaced these reactive forms of action and new forms of competitive action began to develop (Tilly 1978, pp.143-149). Forms of resistance experienced in Turkey during the years the state was formed fits into the second type which is the 'reactive' type.

As Tilly claims, reactive collective actions which took place in Europe during the seventeenth and eighteenth centuries were mainly those reactions against the forces that threatened the rights of local populations. Movements of resistance that took place in Turkey, such as social banditry, military desertion, local uprisings, and ethnic revolts, fit into the 'reactive' type of collective action since they also developed in defence of threatened rights. However, resistance was also very closely linked to the struggle against state authority, both during the War of Independence and in its aftermath. In other words, resistance and revolt were not directed against landlords or local religious leaders based on the belief that the local populations were unjustly deprived of their rights. The local 
pi) werholders and the peasants revolted together against the central authorities. As Mardin notes, "even at the apogee of the Ottoman Empire The Sultan...feared religious leaders, especially popular seyhs and dervishes, and Turkmen rebellions confirmed these fears" (1977, p. 281).

These protests and revolts, which I discuss throughout Chapter Four, were local and regional. Ethnicity and religion did not serve to unify these movements.[20]

Nevertheless both were sources of continuous struggle with the state which was inherited from the Ottoman Empire, and gained a new momentum with the War of Independence and with the efforts to establish a new secular state. During the first period (1919-1923) protest was much more scattered with no clear aims. After the Republic was proclaimed the struggle for an independent Kurdish state and for the reestablishment of a religious state on a new basis appeared as powerful sources for mobilization.

Mardin argues that there is no tradition of opposition in Turkey, referring only to the Progressive Party and Free Party as two examples of unsuccessful attempts of opposition (1965, pp. 377-378). However, according to him, the confrontation between 'center' and 'periphery' is the most important social cleavage underlying Turkish politics (Mardin 1973, p. 170). This confrontation between the 'high' and 'popular' cultures can be traced at various levels other than at the level of parliamentary struggle. The struggle between national authorities and religious-ethnic collectivities can be traced back to the Ottoman times which suggests that there exists a tradition of protest which changed its forms with the advent of time. 
The borders of resistance and revolt were not clear during the formative years of the statebuilding process in Turkey. In addition, there were no well developed economic classes at that time in Turkey. To approach these movements of protest with pre-given opposition groups such as 'Turks-Kurds', 'Westernists-Easternists', and 'secularists-Islamists' is misleading. The Turkish state's articulation to modernism was different from the articulation of the protestors which were sectarian since the Turkish state conceptualized modernism as becoming part of European culture and technology. Central power groups were differentiated from one another during the struggles which took place after World War I. Most disputes were not settled for several years. In this respect, Kemalism and the establishment of a modern secular nation-state was not the only possible outcome of the Turkish Revolution. As the Kemalists gained power with the winning of the Independence War, and as they succeeded in taking steps towards the establishment of a modem state, their opponents reacted in connection to the policies implemented. It can also be argued that these revolutionary policies implemented by the state-makers had a reactionary aspect in response to the aspirations of those who were protesting and resisting.

In other words, in the early days of the state-building process, those involved in protest were not struggling simply against the 'Turkish Republic' or against 'secularism', but against 'state activities' which reflected an ongoing transformative process that was ambiguous in the eyes of many. After the establishment of the Turkish Republic, the nature of this transformation became much more apparent, and the struggle between the state-makers and the resisters had a deeper impact on the form of the new state. In this 
respect, the analysis of the Turkish state-formation process requires a detailed study of resistance and opposition, both at the local and national level, against the state-makers. For, as Corrigan argues,

hegemonic control is always a project, always underway, always attempted, a dayby-day activity rather than something 'accomplished' once and for all. Hegemonic struggle is always in relation to counter-hegemonic struggle --all the way from the important passive resistance of silence and so called apathy, to organized practices of oppositional forms (1988, p. 49).

What follows is a brief overview of the Ottoman past and later discuss the key political and social transformations of the period of Turkish nation-state formation. 


\section{CHAPTER NOIES}

[1] This is the perspective developed by Hobsbawm, and to a certain extent it is a moditied versiun of Leninist theory.

[2] See Blaut (1987). Amin (1980) and Benedict Anderson (1983). This second perspective dies nilf we independence movements as a later stage of the former natuonalism.

[3] Anthias and Yuval-Davis (1989) argue that this tendency to associate the nation with the state creates problems. According to them there are often minorities that are excluded from participation in the state as well as natuonal liberation stuggles by minorities who reside in more than one state, e. g. lake the Kurds or the Palestinians.

[4] Carr divides the international relations into four time periods emphasizing how the concept of nation was first associated with the interests of the rulers, and later how 'nation' was associated with the 'people' (Car 1945). This second period following the French Revolution, may be seen as providing the grounds for equating nations to states. Samir Amin, on the other hand, claims that the comcurrent birth of the nation and of capitalism in Europe accounts for the West-centered distortion of the concept of nation. In this respect, he argues that the works of Marx. Engels, Lenin, and Stalin on the national question present a distorted version of nationalism which is not applicable to the Third World countries (Amin 1980, p. 20).

[5] Amin refers to the Swiss confederation as an example of a functioning system despite real natuonal conflicts. He also refers to the United States and Canada as examples of multinational states where there is no balance among the constituent nations. He emphasizes the fact that federal states are not nation-states questioning whether or not an American nation really exists (1980, p. 129).

[6] See Nimni (1989). Traverso and Lowy (1990), and Lowy (1976) as representatives of the classical Marxist position on nationalism.

[7] Blaut (1987), Hobsbawm (1990), and Breuilly (1982) argue this line. All share the view that creating states or controlling the existing states is fundamental to an adequate understanding of natuonalism. 
|x| Blaut (1987) argues that all national struggles are class struggles. However. he distinguishes two forms which are natonalist and anti-nationalist. For him all nationalist struggles are bourgeois since they take place in capitalist societies. Eastem European struggles for independent states also constutute another form of bourgeois nationalism. Anti-colonial struggles on the other hand are not bourgeois struggles. Amin (1980), too, argues along similar lines. For him contemporary national liberation movements are movements in the socialist transformation of the world and not a stage in the development of capitalism compared to the classical period.

[Y] This view is presented by Connor (1972), Smith (1981), and Shanin (1986).

[10] Shanin argues along similar lines. For him Western European theories focus only on the link between natıonalism and nation-building. He refers to the Soviet theories of ethnicity - developed after 1960s - which view ethnicity as a self-reproducing cultural pattern linked to self-identity, significantly autonomous from the forces and relations of production (Shanin 1986, p. 119). According to Shanin. Westem theory has linked the national problem to the emergence of commercial capitalism and denied the importance of ethnicity as an autonomous force (1986. p. 120).

(III) See Camoy (1984), Chp. 2.

112) Jessop compares Poulantzas's early works with the later ones. He argues that. Poulantzas, in the Crisis of the Dictatorships, emphasized the primacy of the class struggle over structures more strongly when compared to his earlier works (Jessop 1982, p. 157).

[13] Ataturk's hat reform and the restriction on the wearing of the veil are good examples of state intervention at the level of cultural relationships in the Turkish case.

[14] However. Moore. in Ininstice offers a more promising perspective for the study of social protest. Acconding to him, the definition of 'injustice' rests on the violation of a specific 'sociai contract' previous!y accepted by the involved parners. As he argues, "each type of dominant siratum can be expected to have its own form of social contract based upon its own specific principles of social inequality...one main cultural task facing any oppressed group is to undermine or explode the Justtication of the dominant stratum" (Moore 1978, p. 84). Here. as Tilly notes. Moore points to the 
fluidity of relauons of domination implying that there exists 'suppressed histoncial alternatives' and that this suppression cannot be taken for granted (Tilly 1981, p. 212).

[15] Hobsbawm examines the social composition of banditry. Those peasants who have hou employment opportunities in rural environments are most likely to become bandits. Also those who are not integrated into the rural society are forced to become bandits, such as soldiers. deserters, exservicemen. herdsmen, armed men. field-guards. and shepherds (1969, pp. 25-27).

[16] Hobsbawm claims that 'haiduk' is a word of either Turkish or Magyar ongin. In swuth-castem Europe, with the advance of Christian landlord: and Turkish conquerors from the fifteenth century On. groups of free and armed men emerged from among those expelled from their lands or excaped from serfdom. In the Balkan peninsula. Hungary, and North of Greece they were called haiduks (Hobsbawm 1969 pp. 60-61).

[17] Tilly argues that similar groups in similar settings may use different means of collective action, and that a population's repertoire of collective action includes only a few alternatives which change slowly (1978. pp. 151-159). Hobsbawm. too, on a similar ground, argues that a tradition of revolution (or resistance) develops over time which imposes upon individuals fixed practices ( 1983. p. 13). This position implies that different forms of resistance may develop in different reguns of a country. Wolin's concept of 'collective memory contributes to this line of thought. Wolin asserts that a population's collective memory, which is distinguishable from private or individual memory, is related to its historical past (1989. p. 33). In this context, it can be argued that 'collective memory' conceptualized as part of popular culture - plays a role in shaping partems of protest against centralizing tendencies.

[18] Tilly notes that military coups never produce any significant structural change because they involve minor rearrangements. Japan and Turkey are an exception to this rule for the ruling elite effectively prevented other groups from further access to power, and formed coalitions with classes previously excluded from power (Tilly 1978. p. 220). 
119] With reference to political institutions. Foucault refuses to reduce the state to a certain number of functions such as to the development of productive forces and the reproduction of relations of production. The state is related to everything else and. "it is not so much the State-domination of uxciety, but the 'governmentalisation' of the State" (Foucault 1979, p. 20). For him state power cannot be questioned in terms of its 'rationalism' or 'irrationalism'. Rather it is the specific type of political rationality produced by the state that should be questioned (Foucault 1981. p. 242). From this position it can be inferred that forms of resistance to state power reveals the existing 'mode of governing' which is bused on a cerrain type of rationality.

[20] The Islamic population is divided between the 'Sunnis' and 'Shiis' (Alevis). Also regions are divided with regard to their own religious politics. Thus all religious protests which took place in Anatolia remained at the local level and did not initixte any unified peasant movement. In a sense this resembles the millenarian movements experienced in Europe between the eleventh and the sixteenth centuries. As Cohn argues, these millenarian movements were different from the usual revolts of peasants or artisans for they had local and limited aims (1970. p. 15). The Kurdish tribes, too. are divided according to their religious orientations. As Mumcu reports, there were a considerable number of tribes supponting the new state while many were opposing to it (1991, pp. 75-76). 


\section{CHAPTER 3 THE OTTOMAN PAST ANL TURKEY BETWEEN THE TARS OF 1919-1935}

\subsection{Introduction}

The process of state-formation has several aspects that can be analyzed separately. One aspect is to analyze the major forms and locations of state-formation such as the institutions and the links between these institutions. By the term location I refer to different levels of state-formation with regard to building up new institutions or changing the already established ones. In this respect constitutional developments or policies targeting the transformation of cultural relations constitute the different levels where statebuilding process can be located. During the establishment of the new Turkish state a i $w$ army was built, education was unified and centralized. Turkish language was purified, a new civil code was adopted, and many reforms were carried out by the state-builders all 
reflecting different locations of the process of state-formation. A second aspect pertains to the structural connections in the process of state-formation such as the relationship between military and civilian development, between central and local state, and some aspects of constitutional dr elopment. In this study I focus on both aspects of stateformation. Following a discussion of Turkey's link with the Ottoman society (where I also refer to the struggles between the Turkists. Islamists, and Westernists). this chapter focuses on the major forms and locations of state-formation. In Chapter Four. I discuss the second aspect of state-formation through the forms of resistance experienced in Turkey (such as social banditry, peasant revolts, and ethnic revolts) which reflect the relationship between military and civilian development, and between central and local state. I discuss some aspects of constitutional development in Chapter Five. These separate levels of state-formation are linked to broader questions about state-formation which are about what social and political processes and forces led the Turikish state to develop in the way it did? I discuss these more general aspects of state-formation in Turkey in chapters Three, Four, and Five in relation to the key points outlined above.

\subsection{Economy and Pollitics in the Ottoman Empire}

The Turkish nation-state was developed by a class of relatively autonomous bureaucrats independent of those who led the means of production. The historical role of this class was framed by the traditional structure of the Ottoman state and the Ottoman economy. Hence, the Ottoman tradition of state rule and power struggles specific to the Ottoman Empire need to be identified for a better understanding of the role of this class in the formation of the Turkish state. Although military bureaucrats in other Third World 
countries stimu!ated similar transformations. I will argue that the for lation of the Turkish nation-state cannot properly be understood without looking at the Ottoman past. The roots of the bureaucratic power were established long before capitalist penetrattio: and political interests were significant in the establishment of the Turkish statc.

The Turkish military-bureaucratic elite had been largely independent of the econonic alite from the Ottoman times (Suhduing 1970.p. 388). Also this class had a state centered perspective where their primary purpose was to protect the state against extemal and internal threats to its unity. In this respect Turkey represents a unique casc compared to the Western world.

The formation of the Turkish nation-state cannot merely be seen as the outcome of Westemization or modemization. Both the internal dynamics of the Ottoman sxiety and Westernization shaped the route of Ottoman breakdown which gave rise to the establishment of numerous nation-states. In this sense the formation of the Turkisit state is linked to the previously existing social stuctures in the Cttoman Empire.

I now look at the military-bureaucratic class within the context of the Ottoman Emf ire and outline the basic characteristics of the Ottoman society which are relevant for analyzing the process of transition towards a modern nation-state.

The two classes of the Ottoman Empire were those which represented the ruler's authority (the administrators, the troops, the men of religion), and the ordinary subjects (the ullers of the soil, the merchants, and the craftsmen). The former were not producers and paid no taxes. while the iatter were the producers and the .. payers (Inalcik 1969, p. 97). 


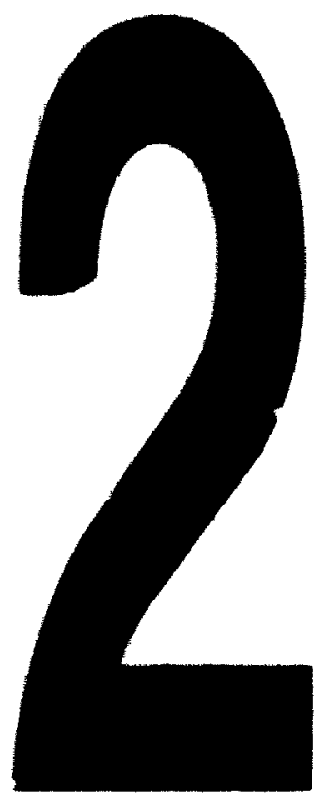

PM-1 31/2"X4" PHOTOGAAPMIC MICAOCOPY TARGET NaS to10: AMEI/SO \#2 EOUNALENT

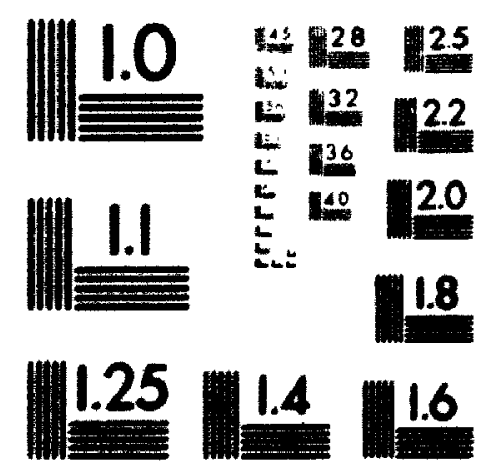

Preckionem ncsoution tanceTs 
Agricultural and artisanal production was strictly controlled by the state. As Inalcik argues. "Whereas the craftsmen were strictly controlled in their buying of raw materials and in the production and sale of their wares. the merchant remained free to accumulate...as much capital as he could, and to seek always to increase this capital" (1969, p. 98-99). The state also controlled the profit margins and the technology of production of the former group which prevented capital accumulati.n in the Ottoman Empire.

The merchants cocperated with the administration: "they made loans to the state, they acted as intermediaries between the state and the mass of the population in matters of taxation, they ensured a steady revenue from customs charges, they supplied the administrative class with goods produced far afield, and they acted as agents and ambassadors" (Inalcik 1969, p. 102-103). The merchants were also economically important. International trade supplied luxury goods and also provided essential food and raw materials to the cities. The Ottoman state protected the guild system and opposed developments initiating industrial capitalism. Artisanal production was in the hands of the guilds which remained relatively unchanged during the Otoman period. By protecting the guild system the state never moved in the direction of a mercantilist economy as Europe did (Inalcik 1969, p. 135). State control over economic life was motivated by the desire to support and protect the military structure of the empire (Mardin 1969, p. 262).

It is mostly argued that the Greeks, Armenians, and the Jews were those especially involved in extemal trade, while the Turks were trading with the provinces and that it was these ethnic and religious minorities who were involved in artisanal production, wholesale 
trading. and commerce. Here I quote at length from Inalcik who questions this commonly held view with regard to the Ottoman society:

This is the place to correct the mistaken view that these merchants and bankers were non-Muslims, and that Muslims entered only the profession of arms and the administration. This error is the result of projecting back into earlier centuries a development which occurred only after the eighteenth century. It can be said quite definitely that until the eighteenth century Muslims were as numerous and as active as non-Muslims in these fields-indeed until the seventeenth century the Muslims predominated among the merchants. In the sixteenth and seventeenth centuries Muslim merchants also engaged. without intermediaries, in commercial dealings in Europe, though it is true that in contacts with the West. Jews. Armenians, and other non-Muslims were, not unnaturally, more numerous and more active. That these later gained the upper hand in the economy of the Empire may well be related to the fact that the Empire's trade with the East declined and trade with the West gained in importance $(1969$, p. 138).

These non-Muslim minority groups were excluded from the political realm. There was no Muslim bourgeoisie from which economists could have been recruited for the bureaucracy and, "the absence of a Muslim-Ottoman and later a Turkish middle class earning its livelihood in trade, manufacture, communications, or even the professions was a serious barrier to economic growth as late as during the early days of the republic" (Sugar 1964, p. 153).

The minority groups performing these economic activities and services holding no power in the central government constituted a threat to the central authority as they became more and more integrated into Western capitalism since they were making religious and ethnic claims challenging the state's legitimacy. Keyder claims that, "the Christian bourgeoisie attempted to stage their struggle in the inter-state theatre, not principally through social demands designed to favour their access to political authority, but through demands of ethnic and religious autonomy. From this point of view, the Christian commercial 
bourgeoisie never entertained the option of becoming a class for itself through exercising influence over the state" (1988, p. 200). In other words. the Christian merchants had always rejected the Ottoman state as a legitimate field of political struggle since it was closed to them.

In the Ottoman Empire the vakif (Islamic pious endowment) was a major source of capital accumulation. In Inalcik's words, "Although the aim of a wakf was to suppon a charitable object pleasing to God. in practice most wakifs benefited individuals; family wakfis....were founded with the deliberate object of protecting the interests of a specific fanily" (1969. p.132). In the Uttoman Empire most vakifs were founded by the members of the ruling class. The members of the military-administrative ciass who formed the higher ranks in the society earned large incomes both from timar-estates (land granted by the state which was later owned by this class), and from the farms which they had organized as agricultural enterprises. They invested their income in long-distance trade or in moneylending at high interest rates. The incomes of this class, whose wealth derived originally from state payments, "were particularly exposed to confiscation by the state; thus many of them invested their wealth in walf foundations...as being the best protected and most permanent source of income" (Inalcik 1969, p. 136). Landowners, administrators, and the ulema (clergy) earned large incomes from their estates and vakif holdings. However. the vakifs never assumed the characteristics of a really capitalistic enterprise leading to investments in industrial production.

These basic economic principles of the Ottoman Empire were linked to the structure of the Ottoman state. The Ottoman rulers had absolute power over their subjects and they 
established a type of administration that prevented the development of privileged classes other than themselves.

The position of the rulers in the Ottoman Empire is described by Inalcik as follows:

Ottoman society was divided into two major classes. The first one, called askeri, literally the 'military', included those to whom the sultan had delegated religious or executive power through an imperial diploma. namely. officers of the court and the army, civil servants, and ulema. The second included the reava, comprising all Muslim and non-Muslim subjects who paid taxes but who had no part in the government. It was a fundamental rule of the empire to exclude its subjects from the privileges of thr. 'military'. Only those among them who were actual fighters on the frontiers and those who had entered the ulema class after a regular course of study in a religious seminary could obtain the sultan's diploma and thus become members of the 'military' class (1964, p. 44).

The 'reaya' or the ruled, on the other hand, included the subjects which were divided into various groups such as the Muslims and non-Muslims, townspeople and peasants. sedentaries and nomads. Each group had a different status which was reflected in their tax obligations. The peasants lived on state-owned lands as tenants and they were subject to special taxes. They could not leave their lands, or settle in towns.

In parallel with the economic changes which took place in the sixteenth century this rigid social system also went through a transformation. In this context, the tensions and power struggles between the bureaucrats (which included officers of higher rank from the military, administration, and judiciary) the religious autrority, and the local notables needs to be briefiy mentioned.

The Ottoman Sultan protected his ultimate authority by establishing a highly centralized state power. The concept of authority in the Ottoman Empire was personified by the 
Sultan and Sultan's power to rule was absolute. The Sultan represented the state in the name of the God. This natrimonial structure of the Ottoman state emerged as its most characteristic aspect. The notion of authority was also linked to a strong tradition of the state and to the principle of public welfare all contributing to the distance between the rulers and the ruled. The absence of intermediate institutions (or the absence of a civil society) and the lack of autonomy of economic structures can be seen as a reflection of this strong state tradition. According to Mardin, the wielders of political power, not the merchants, were the first citizens of the realm and the tight control established by the state over the economy was a further example of the primacy of politics in the Ottoman Empire (1973, p. 172).

The Ottoman millet system as the basis of societal organization was the most striking characteristic of the Ottoman state. As I discussed in Chapter Two, section II.2.3, the millet system which was based on ethnic and religious differences can be seen as the basis of the segregated Ottoman society as well as explaining the distance between the rulers and ruled. As Goffman points out, "the millet system helped the Ottoman state to organize and categorize those it ruled, and to function as a legitimate source of authority over them" (1994, p. 138). In the Ottoman Empire the system grouped various sections of the population according to their religious and ethno-linguistic affiliations, disregarding their occupational status (Karpat 1973, p. i). This system produced a series of 'nationalities' or 'nations' which carried the Ottoman stamp (among these millets were the Muslims, Orthodox Greeks, Gregorian Armenians, Jews and Catholics). 
The Ottoman state regrouped the already existing ethnic, religious, social and economic groups into a new organizational framework. The social estates cut across ethnic and religious affiliations and regrouped the subjects in accordance with their occupation and function, such as military, administrative, religious, cultural, trade and crafts, and food production (Karpat 1973, p. 7). Thus groups were both separated from one another at one level (religious) and united at another level (occupational). This was a deliberate policy of the Ottoman government. The principal purpose was to separate groups from one another in order to avoid vertical social mobility. This separation was very visible since each millet had to wear different clothing. In this respect the millet system provided for the maintenance of the existing identities. The military-ruling class was responsible for keeping each social group in its assigned status and rank. The non-ethnic character of the elites (I discuss this point below) representing the state was an important characteristic of the Ottoman state contributing to the separation between the rulers and the ruled.

Here it is worth mentioning the three institutions through which the sultan maintained his power, which were the administrative staff, the cavalry men, and the lanissaries. It is also important to note that the struggles within the ruling class stemmed from the breakdown of this system of central organization.

As already discussed, the first institution was the administrative staff called the 'servants of the porte', which w: bound unconditionally to the ruler, and detached from social classes. The second was the cavalry men called the 'sipahi', who were granted fief benefices (timar)for tested service in war and who were subject to the favour of the ruler. The third was the central military force called Janissaries again completely detached from 
their social origins and directly bound to the ruler. In this rigid military system nonMuslim minority groups were exempt from military service which further contributed to their isolation from the political realm.

State control over the land was firmly dependent on this military organization within the empire. In this respect the sipahi and Janissary organizations require further elaboration. Also the transformations within the military reveal the nature of the changes that look place in the Ottoman society from sixteenth century onwards.

Originally all land belonged to the Sultan who represented the state, but land was distributed as timar holdings among the sipahi. The sipahi (provincial cavalry) "had the right to administer a certain land and eam the tithes and dues in return for so many numbers of soldiers and fiefs...This manner of appointment of administrative duties reduced the fiscal burden of the state since it did not have to pay salaries in cash. The central power appointed the timar holder or the sipahi. Ownership of land was forbidden and titles and rights were not inherited" (Cesur- Baykan 1988, p. 20).

As Bozdemir notes, this provincial army (the sipahi organization) was not established only for defence. The state maintained its control over the land through the sipahi organization. In this way part of the military became involved in agricultural production. The sipahi forces were basically the peasants who were subject to conscription in times of war by order of the Sultan (Bozdemir 1982, p. 43, 51). Although this provincial sipahi organization depended on the peasan.s it was far from representing the peasantry at the level of the state since they had no rights in legal matters. The provincial cavalry formed 
the backbone of the army in the early history of the Ottoman Empire. Later in history as the Janissary organization gained more importance the sipahi organization began to break down (I discuss this transformation below).

The Janissary organization, as opposed to the provincial cavalry, was totally detached from society. In this respect it reflected the separation of the rulers from the ruled. The Janissaries were the trained infantry corps which were formed by the Christian youths. which was known as the devsime system. When new lands were occupied, young Christian children, between the ages of five and twenty, were collected and converted to Islam. Those best in appearance were selected as Janissaries. The orphans, epherds, the married, and those who knew Turkish were left aside (Bozdemir 1982, p. 56). These young children passed through a strong education and they served the sultan and his army with absolute loyalty. The Janissaries were the Sultan's slaves with no rights of marriage and property ownership.

This system (devsirme) was designed to guarantee the strongest personal loyalty to the ruler. Tachau quoles from Ozbudun, "the significance of this...[system]...is that since these slaves became the Sultan's property and since he could take their lives and confiscate their wealth without legal process, they were in no position to challenge his authority. Furthermore, the fact that they were entirely cut off from their former social environments prevented the development of locally entrenched semi-autonomous elements in the provinces" (Tachau 1984, p.61). 
The Janissaries. unlike the cavalrymen. were paid in cash. They had a privileged position in the army and in time it became very advantageous to be a Janissary since it provided the opportunities for upward mobility within the ranks of the bureaucracy. For example. there were a number of non-Turkish (Greek. Armenian. Croat. Albanian, Russian. Hungarian. Italian) grand viziers who were formerly 'servants of the palace' (Bordemir 1982. p.57). Christians had more chances for upward mobility through this system. The Turks and the Muslims, on the other hand, were excluded from this military system for the Muslims could not be enslaved. The Muslims were rewarded with a timar holding only in retum for their success in military operations in times of war.

From the sixteenth century onwards the trade routes changed and this negatively affected the role of the Ottoman Empire in the world economic system. In addition to changing trade routes, the discovery of silver mines in America affected the Ottoman economy for the monetary system of the empire was based on silver currency. As a result of abundant amounts of silver brought from America the Ottoman currency was devalued. The guild system and artisanal production was destroyed by extensive imports from abroad. As already discussed the military organization and agriculture were closely linked to one another. The timar system and the taxes collected from lands conquered were the financial sources for state expenditures and for the salaries of the soldiers. Trade problems, limited cash and growing inflation also fostered problems of territorial control which further contributed to this fiscal and economic deterioration. With declining territorial control and conqrest the Ottoman state began to lose its major sources of 
finance, and had to rely more on agricultural production for financing the state expenditures and loans.

Following these developments, "the Ottomans discarded their timar cavalry in the provinces and increased the force of Janissaries. who were by this time equipped with firearms. This neglect of the fief holders within the army was followed by the disorganization of the land and taxation system upon which their status had been based" (Inalcik 1964, p. 45). As the cavalry lost its significance the state began to distribute the fiefs to the rest of the military class by leasing them. As Berkes puts it, "the army of benefice-holders (sipahi) had virtually disappeared as a result of the expropriation of fiefs by derebeys, government, Yeniceris (Janissaries), and tax-farmers" (1964, p. 56). With these developments the Janissaries became more powerful both politically and economically. As Cesur-Baykan writes, "in the seventeenth century, starting with the suppression of the Celali peasant revolts, Janissaries were sent to provincial states where they became established and made their positions hereditary" (1988, p. 25). According to Inalcik. "in the period when central authority grew weaker, these Janissaries took over the actual control of the government in such distant parts of the empire as North Africa. Baghdad, and Belgrade...The vezirs, courtiers, and heirs to the throne all sought their aid to attain power" (1964, p. 46). They also obtained some privileges. They were allowed to enter guilds, engage in trade, and to marry and have children. Following these developments being a Janissary became very advantageous; while many Christians tried to buy Janissary positions for their sons, some Turks claimed that their children were 
Christians in order to obtain such positions (Bozdemir 1982. p 57: Cesur-Baykan 1988. p. 25).

It was in the eighteenth century that the Janissaries, the ulemil (clergy). and especially the ayan. a newly rising semi-feudal landed aristocracy in the provinces. gained power within the empire. Here I look at the peasantry and to the emergence of the local notables in more detail. The term ayan refers to the provincial or local notables who were the most influential and wealthy citizens in a town. Many were local officials or Janissary officers who had risen by exploiting their official position. Later in Ottoman history the term specifically meant a definite social group or class of old and new landlords. The ayan replaced the fief holders in the state-owned lands as lessees or tax collectors (Inalcik 1964. p. 47). Local notables benefited from leasing state lands (in the eighteenth century the leases were made for life) and from tax farming by exploiting the peasants. They elected their own leaders and representatives who were recognized rather than appointed by the government. The ayan became the local agents of the Ottoman state in financial and administrative matters. As Inalcik notes, "increasingly in need of new troops for its prolonged wars...the state encouraged the ayan to equip at their own expense the forces under their direct command" (1964, p. 48). This semi-feudal aristocracy in the provinces played an important role in the Ottoman history from the eighteenth century onwards. During the period of decline the local population increasingly relied on local notables. However, as Mardin states, despite the growth of their influence and authority, these notables still had no autonomous status comparable to that of the European feudal nobility (1973. p. 174). 
During the period of decline. which started in the sixteenth century. the Ottoman rulers adopted the idea of reform. However, the ulema (clergy) and the ayan in the provinces resisted any reform movement which threatened their interests. The ulema and the newly arising local notables had good relations with each other and they formed a bloc in opposition to the sultan and his administration in response to these reforms that threatened their positions.

From the zighteenth century onwards the state was engaged in reform movements along Westem lines within the empire. Western social institutions such as the military and the schools began to be adopted as a solution to the Empire's problems. The main motive behind these reforms was to restore the military power of the empire. As Cesur-Baykan notes. Damat Ibrahim Pasa, who was the grand vizier between 1718-1730, “established embassies in major Westem capitals and sent people to study their civilizations and institutions. The major source of interest was the way in which armies were organized and the techniques and the training methods they used" (1988, p. 27). Also this was the period when Westem ideas of nationalism and the influence of French culture began to foster within the palace. Sultan Selim III (1789-1807), who has been regarded as the father of Ottoman-Turkish Westernization. engaged in reform movements within the empire. He was interested in Western military and administrative establishments and formed a new and a modem army (Nizam-i Cedid) similar to the Westem ones. Not only European weapons but also European sciences, training procedures and uniforms were introduced by Sultan Selim. These developments were not welcomed by the ulema (the clergy). the Janissaries and the 'ayan'. The ulema was mostly opposing to the new schools 
and Western science which were undermining the power of the religious groups. As Inalcik writes. "his efforts to create a regular army under his direct command threatcned the dominant position in the state of the Janissaries. on the one hand. and of the alyan. on the other" (1964, p. 50). In 1807 the ulema (the clergy) and the Janissaries, who wire involved in numerous uprisings. managed to depose Selim III.

Following Sultan Selim. Mahmut II (1808-1839) came to power and he made altempts to reestablish state's power in the provinces. He first suppressed on 'ayan' uprising in the provinces relying on the Janissaries. After fighting against these revolts. he atholished the Janissary order in 1826 and formed a new army. The establishment of this army weakened the ulema who often allied with the Janissaries. In order to control the ulema financially the vakifs were brought under the control of the government. Mahnut II also organized the government along secular principles. He established "public laws outside the domain of the sheriat in order to conduct the actions of the state officials and the judges...the jurisdiction of the religious affairs was separated from the jurisdiction of temporal affairs, each functioning through a different body" (Cesur-Baykan 1988. p. 29). He also initiated vario'ss reforms in the area of education by opening a military academy. an engineering school. and a medical school. The opening of this military academy was especially important since this was the first time that the military officers were recruited not from among the 'foreigners' but from among the common people of the empire (Bozdemir 1982, p. 67).

In 1831 Mahmut II abolished the 'timars', the old feudal holdings. This reform was designed to weaken the power of the sultan's main opponents. the landlords. The Land 
Code of 1858 reasserted the state's title to lands. However. according to Karpat, although the law was to transform the traditional form of state ownership into a modem concept of public ownership. in reality much of the land came to be accumulated in private hands (1973. pp. 94-95). Modern forms of large land estates and a land-owning class emerged after the adoption of the Land Code of 1858. This was the basis for the emergence of new leadership cadres among the Muslims. This new freehold landlord class controlled much of the countryside of the Empire. In the Balkan provinces this gave rise to social struggles, which continued after those countries had won their independence. In western and central Anatolia it produced the aga, the rich peasant or landlord, dominating and often owning the village (Lewis 1968, p. 450).

The 'ayan' and the ulema were hostile to Mahmut's reforms and the central authority feared from the total destruction of the empire. During this period a new' generation of reformers emerged. The new reformers were chiefly diplomats. As Inalcik points out. "Their training was a practical one in the state bureaus, differing from that of the military...and more markedly still from that of the ulema...the bureaucrats gained an increasing influence in the administration from the eighteenth century on" (1964, p. 55). A Translation Office was created in 1821, when the Ottoman government had to replace the Greek interpreters with Turks. This Translation Office, together with the embassies in Western capitals established by Selim III, became an educational center for Westernized administrators and intellectuals (Inalcik 1964, p. 55).

The period after Mahmut II is known as the Tanzimat (regulation)period (1839-1876). During this period the state became centralized more than ever hoping to restore the 
strength of the empire. The Ottoman reformers attempted to unite all non-Muslim minority groups undel the banner of 'Ottomanism' which provided equal rights to all subjects before the law and provided a common Ottoman citizenship for all. Protecting the Christians was a protective measure taken against any demand for independence from the empire. However, the national integration of the non-Muslim components of the Ottoman Empire was a failure in the sense that losses of territory during the nineteenth century and early twentieth century could not be prevented.

It was the 'Young Ottomans' who established the First Constitutional Monarchy in 1876 under these circumstances which is regarded as the first phase of the Young Turk movement. In this context. Turks referred not to an ethnic community within the empire. but to a religious-linguistic category. Turks were defined as part of the broader religious community which was the community of Islam. The 'Young Ottomans' movement was started in 1864 by Turkish intellectuals in exile who formed a secret society. In 1867 they established the 'Young Turk Party' in Paris. The supporters of this party later became known as the Young Turks (Bozdemir 1982, p. 70). The First Constitutional Monarchy established by the Young Ottomans in 1876 aimed at preserving the traditional IslamicTurkish culture while accepting elements of Westem civilization. In 1878, with the start of the Russian War, the regime established by the Young Ottomans was abolished by Sultan Abdulhamit who developed close ties with the religious organs and ruled for thirtythree years (1876-1909).

In 1889 the (Ottoman) Committee of Union and Progress (CUP) was formed in the military medical school in Istanbul (Mardin 1983, p. 60; Steinhaus 1974, p. 48).[1] This 
marks the beginning of the second phase of the Young Turk movement. The Committee of Union and Progress, known as the 'Young Turks'. grew rapidly and found supporters among many Western oriented intellectuals in military, medical, and civil schools in Istanbul and among those in exile in Europe.

The breakdown of the traditional system of education. new recruitment into the administration, and the split within the bureaucracy are all important in explaining the conflict between the Young Turks and the Palace. Here I briefly look at the class base of this new bureaucratic strata. The Young Turks were from the class of administrators. As administrators, they were from the military or the civilian bureaucracy. However, according to Karpat, at the beginning. "the actors of the Young Turk era were not only Turks but also Arabs, Greeks, Jews, Armenians, Bulgarians, Albanians, Vlahs, and members of other national groups, who were struggling to reconcile their ethnic and religious allegiances and national ambitions with the political loyalty demanded by the Ottoman government" (1975. p. 279). The Young Turk movement acquired its true significance later when they adopted Turkish nationalism (where the Turks were no longer defined as a religious community but as a community that has political and cultural unity) as a solution to the Ottoman breakdown.

In late nineteenth century, as the result of Ottoman reforms, new departments within the government were established and local administrations were modemized. In Keyder's words, "there were qualitative changes within the bureaucratic class as well -that modem and secular component of it which supplied the ranks of both reformists and revolutionaries grew in size and importance. due in large part to the educational 
institutions established to reproduce their cadres" (1988, p. 19.3). The graduates of these new schools joined the bureaucracy. to serve either in the military or in the central government. These intellectuals initiated the revolutionary movement. and they all belonged to the bureaucratic class.

According to Mardin. most of the Young Turk leaders were of provincial or of lower-class origin. As Mardin notes, it became a tradition to recruit the members of the military from among the common people since the times of Mahmut II. especially after the abolition of the Janissaries. The main reason for this was that Mahmut Il deliberately attempted to avoid a system where the military officers were affiliated with influential families. In the military and medical schools the students were divided into two, those from the 'provinces' and those from 'Istanbul', and were in continuous conflict with each other. The provincial students were not part of the Palace culture and they were the ones who later formed the Committee of Union and Progress (Mardin 1983, pp. 57-58). Although they were from the provinces, in Mardin's words, "the generation of Young Turks who in the 1890's were combatting Sultan Abdulhamid II singled out positivism - and later a solidarism inspired by it - as their favourite ideology" (1969, p. 27). With the success of the Young Turk Revolution of 1908, notables began to appear in the ranks of Ottoman political parties and in parliament (Mardin 1973, p. 178). Ahmad compares the Young Turks with the Young Ottomans. In his words,

Whereas the Young Ottomans were members and products of the ruling institution. the Young Turks belonged to the newly emerging professional classes; lecturers in the recently founded government colleges, lawyers trained in westem law. joumalists, minor clerks in the bureaucracy, and junior officers trained in the westem-style war colleges. Most of them were half-educated and products of the 
state schools. The well educated ones had no experience of administration and little idea about running a government. There was not a single experienced statesman amongst them (Ahmad 1969, pp. 16-17).

Now I briefly outline the ideological orientations of the Young Turks, influenced by European ideas and develupments as discussed earlier, who became the rulers of the country after the 1908 Revolution (1908-1918). The Young Turk Revolution developed. in part, as a reaction to the failure of 'Ottomanism' as the political principle of Ottoman reformers who saw constitutional federalism as a solution to the Empire's problems. While Islam was the unifying force for the Young Ottomans. Turkism gained importance as another unifying source among the Young Turk intellectuals especially after the 1908 Revolution. The Young Turks, defending Western values against traditional values, were also opposed to the government and to the sultan.

Ahmet Riza was one of the leading figures of the Young Turk movement who joined the group of exiles (who were mostly the political opponents of the sultan) in Paris in 1889. In 1895 he began to publish a paper called the 'Mesveret' (meaning consultation) under the influence of positivist philosophy; it became the official organ of the Committee of Union and Progress. Before Ahmet Riza, Islam was an important element in all political and ideological philosophies which developed throughout the empire. However, positivism became the dominant philosophy in Ahmet Riza's writings which marked an important break in the Ottoman intellectual tradition. The Young Turks were influenced by the positivist doctrine in the West and they studied the theories of Rousseau, A. Comte, Spencer, and Durkheim. The Young Turks "were looking for a European model of 
modernization without necessarily being European. a way to secularize while staying Muslims" (Cesur-Baykan 1988. p. 75).

There were splits among the Young Turks, both personal and ideological. who were grouped in various centers such as Paris. Geneva. Cairo, and London. In 1886 another leader, Murat Bey, began to publish the weakly 'Mizan' (Scale or Balance) which had a religious orientation. Murat Bey united Turkism with Islam. This was not a new synthesis, but now Islam appeared as a political rather than a divine force in leading the masses (Mardin 1983, p. 91). Murat Bey's pan-Islamism and pan- Turkism became very influential within the Young Turk movement and especially in the press.

Another leading figure was Prince Sabahattin, the sultan's nephew in exile, who challenged the ideas of Ottomanism. Islamism, and Pan-Turkism. He fought for a federalized and a decentralized Ottoman state. As Lewis notes. Prince Sabahattin held the view that, "a constitutional monarchy, on British lines, would provide a minimum of central government; for the rest, the different peoples and communities of the Empire could satisfy their aspirations and safeguard their rights in regional and local government and in a public life emancipated from collective or governmental control" (1968, p. 204$).$ Prince Sabahattin's views were not welcomed by many among the Young Turks which, in a sense, questioned the integrity of the empire.

Most of the leaders of the Committee of Union and Progress were from Rumeli (the Balkan provinces of the Ottoman Empire) rather than from Anatolia and they were mostly officers, doctors, and teachers (Berkes 1964, p. 329). The Balkans were the center for the 
Committee of Union and Progress where Turkish intellectuals could easily contact and cooperste with other Muslim and Christian intellectuals who were against the sultan's despotic rule. The Committee of Union and Progress was a masonic type organization and some of its members had personal relations with the European masonic lodges while they were abroad (Tunaya 1989, p. 322; Kabasakal 1991, pp. 74-75; Tuncay 1992, p. 164; Bozdemir 1982. p. 74). This contact with the West contributed to the spread of Westem ideas among the Turkish intellectuals. However, as Ramsaur claims, Freemasonry was not the only secret organization which contributed to the growth of the Young Turk movement; some of the dervish orders of Turkey were made use of as the Masonic lodges. In Ramsaur's words,

Of the Turkish dervish orders, by far the largest and most influential was that of the Bektashis...a very large percentage of the membership was composed of illiterate peasants and almost as illiterate 'sheyhs'. Nevertheless, the order did attract many Turicish liberals and nationalists, for the Bektashis were the most Turkish in spirit of all the dervish orders. In contrast to the Mevlevi order (the famous 'Whirling Dervishes'), for example, the Bektashis clung to the Turkish language and Turkish forms in their literature all during the period when the cultural life of the Turks was largely dominated by the 'classical' influences of Persian and Arabic (1970, p. 109).

In the years before the 1908 Revolution many new groups were being formed in Macedonia and Anatolia by the officers within the Empire. In Salonica a new committee was formed by the officers of the Third Army Corps. It is assumed that Mustafa Kemal had some influence in the formation of this organization. In 1906 the groups established within the Empire came together and formed the 'Ottoman Society of Liberty' (Lewis 1968. p. 205). This society, after contacting the Young Turks in Paris, changed its name to 'Union and Progress' once again (Cesur-Baykan 1988, p. 74; Mardin 1983, p. 133). The 
Salonica group also joined the Young Turks living in Paris in 1907. These were significant steps for future developments.

The revolutionary committees formed by the Young Tarks sent an ultimatum to the sultan demanding the immediate restoration of the 1876 Constitution. and the sultan proclaimed the constitutional system in July 1908 in response to the growing influence of the revolutionary societies. Ahmet Riza was appointed as the prime minister by Sultan Abdulhamid. The Sultan was deposed by the new regime in 1909. There were divisions among the new rulers of the country. On the one hand there were the Unionists. on the other the Liberals. The Liberals favoured decentralization and they supported the nonTurkish communities. As Berkes writes,

In the years following the Revolution two political parties came into existence in opposition to the Union Party. One was called Liberal (Ahrar), or, as it re-emerged later, the Party of Liberty and Conciliation (Hurriyet ve Itilaf), known to the European press as the Liberal Entente. The other was a political formation calling itself the Muhammedan Union (Ittihad-i Muhammedi), which wanted Islamic unity as the basis of the Ottoman state. The nationalists (Armenian. Greek. Arab and Turkish) joined these parties only to influence them or to cover their own secret or suppressed organizations. The Arab and Armenian secret organizations were the most active (1964, p. 330).

The Party of Liberty and Conciliation which was formed in 1911, despite its heterogeneous composition, was against nationalist tendencies and Westernization, defending the principles of Ottomanism (Selek 1963, p. 75). The Committee of Union and Progress, in reaction to this opposition, became a political party in 1913 relying more on repressive policies to breakdown the growing influence of the liberal parliamentary opposition. After the Grand Vezir Mahmut Sevket Pasa's assassination in 1913 the 
Unionists started to govern with absolute power. From 1913 untill918 Enver, Cemal, and Talat Pashas became military dictators with no serious opposition challenging their rule.

The Committee of Union and Progress was the nationalist power behind the throne from 1908 to 1918. They formed branches of the Committee of Union and Progress in almost every town which became the basis of provincial political organization. The Union and Progress Party had power over some organizations such as the 'Turkocagi' (Turkish Heart) which was an organization spreading out the nationalist ideology of the Turks at the cultural level (Kabasakal 1991, p. 70).

Members and supporters of the Committee of Union and Progress played an important role in Turkish politics and in the establishment of the Turkish nation-state based on the European model. However, they later became the opponents of Ataturk. I will discuss the conflicts between the republicans and the Unionists when looking at the opposition movements within the parliament. The struggles between the Turkists, Islamists, and Westernists continued to remain at the center of political conflicts during the formation of the new Turkish state.

\subsection{Turkey Between the Years of 1919-1928}

The formation of the Turkish nation-state includes both the Turkish War of Independence which took place between 1919 and 1923, and the period of single party rule which continued until 1950. However, by the mid-1930s the formative years of the Turkish state had already came to an end. 
The years between 1919-1923 and its aftermath (1923-1935) were, in fact. two different periods with regard to the nature of conflicts and struggles experienced in the process of building the new Turkish state. I discuss these two periods under separate headings. In this chapter I focus on the major forms and locations of state-formation such as the building of new institutions which is intrinsic to the state-formation process. However. I also describe both the alliances between various parliamentary and non-parliamentary groups and their breaking apart since these alliances and conflicts reflect the critical points of transition during the process of establishing a modern nation-state in Turkey.

Moreover, in this and the following section I look at some of the major political and soxial transformations that led the Turkish state to develop in the way it did. I discuss this last point more fully in chapter IV.

The core of the struggles described in this section was the building of the new Turkish state by the Nationalists who aimed at cverthrowing the traditional Ottoman regime. Between the years of 1919-1923 the Nationalists not only fought for the establishment of a new state but they also tried to save Anatolia which was occupied by the Allied armies at the end of World War I. During this period although there was local resistance to the occupation itself, there also was resistance to the efforts of the Nationalists to form a permanent grmy with the intention to save the country from the occupiers. Nevertheless Mustafa Kemal (later known as Kemal Ataturk) and his followers managed to coordinate these local movements of resistance against the occupiers at the national level. The developments that took place between 1919-1923 led to the establishment of the National Assembly in Ankara, the proclamation of the republic, and to the abolition of the 
Sultanate and Caliphate. These developments were central in the process of establishing a modern nation-state in Turkey.

According to Kurat, Turkey entered World War I for two reasons. First, the Russians threatened to occupy the Straits and Istanbul. Second was the Turkish demands for the return of the Aegean islands by the coast of Anatolia that the Greeks had occupied during the Balkan Wars. France and England refrained from giving any guarantees to Turkey against Russian threats as they needed to use Russia against Germany. They were therefore reluctant to hurt Russia's sensibilities and refused to support the Turks for the return of Aegean islands. However, Germany guaranteed Turkey against Russia and yet did not commit itself on the Aegean question. As a matter of fact. German design was to use Turkey in its war aims against its enemies, namely Russia, Britain. and France. Enver Pasha, the master of Turkey behind the curtain, fell into this trap and precipitated his country's entry into the war hoping that Germany was invincible and that German victory would consolidate and reinvigorate the Ottoman Empire (Kurat 1967).

When World War I ended on October 30. 1918 the Ottoman Empire was forced to sign the Moudros Armistice on October 30, 1918, making it one of the defeated Powers of World War I. In the following days an Allied military administration was set up in Istanbul, and Allied troops occupied the city. In 1919 French, British, Italian, and Greek troops occupied several parts of Anatolia.

In 1919, with the ending of the war, the new Sultan (Mehmed Vahdeddin 1918-1922) arrested the former leaders and supporters of the Party of Union and Progress which had 
disbanded itself after the war. Most of its leaders escaped abroad. including Talat. Enver. and Cemal Pashas. However, the members of the Committee of Union and Progress continued to play an important role in the years that followed. I refer to this group as the Unionists in the following pages. After the rule of the Committee of Union and Progress came to an end, the Liberals in exile returned to the country. All opposition groups. together with the Liberals, attacked the Unionists who were seen as responsible for the damages of the war. The Party of Liberty and Conciliation, which was first established in 1911 against the Unionist rule, was formed once again in 1919. This time their aim was to take revenge on the Unionists and to restore what they have achieved in the past.

The new ruling group in Istanbul believed that Muslim unity under the British wing was the best alternative to an independent existence. They wanted to protect the Ottoman Caliphate and the Ottoman Sultanate under British tutelage.

The dissolution of the Ottor in Empire and the separation of the Arab countries did not initiate a Turkish national movement. The Turks did not respond to the Allied powers when they first occupied the Anatolian territories. As Aybars points out, the peasants. who carried out the burden of the wars from 1913 to 1918 , remained indifferent to what was happening mainly because they hated the idea of war (Aybars 1988, p. 7).

However, the landing of the Greek army at Izmir on May 1919 was seen as a threat to the existence of the Turks. When the Greeks intended to incorporate the western territories of Anatolia containing Greek and Armenian minorities in Greece, the Turks reacted. At the beginning of this period Istanbul was the centre of political struggles and the first protest 
meetings and secret resistance movements took place in Istanbul. As disputes over future developments grew, protest shifted to Anatolia. Western and Eastern Anatolia witnessed many local and spontaneous resistance movements. The local intellectuals. merchants. lawyers. doctors. teachers. landowners, and clericals formed 'Societies for the Defence of National Rights' (mudafaa-i hukuk) to resist the invaders. Selek claims that the rumours about the creation of an independent Armenia in East Anatolia, a Greek Republic of Pontus out of the Turkish Black Sea coast, or rumours about the Greeks claiming the possession of Izmir were the main reasons for the formation of the Societies for the Defence of National Rights (1963. pp. 79-80).

The total number of political parties and organizations established between the years of 1918-1922 was 31, and most of these parties and organizations were supporting the government in Istanbul (Kabasakal 1991, p. 77). However, the societies formed for the defence of national rights, which were the first resistance groups. differed from the existing political parties and organizations in terms of their purposes and organization. These societies remaine i "utside the political atmosphere in Istanbul. In Berkes's words,

Their aims were to protest the partition of the Turkish territories, to demand the observance of the Wilsonian principles with respect to themselves, and to pledge themselves to resist aggression and invasion. Despite remarkable uniformity in the actions and decisions of these organizations, they were purely local or regional. The groups were neither co-ordinated nor united. They were incapable of elucidating a nationwide or positive policy. Some sought a solution in the restoration of the Seriat, some advocated decentralization and local autonomy, and some toyed with the idea of establishing autonomous soviet republics (1964, p 433).[2]

From December 1919 onwards 'Societies for the Defence of Rights' were formed in Thrace and Anatolia.[3] By 1920 there were more than thirteen Societies for the Defence 
of National Rights. Most of these societies were first formed in Istanbul and the I'nonists played an important part in the formation of some of these organizations. In some regions the existing political parties and organizations joined these societies such as the one formed in Izmir. The agents of the resistance movement were these organizations and nor the peasants. The peasants, who were deserting from the army back to their villages. were exhausted by the wars from 1913 to 1918. and they preferred to remain ontside of these newly formed organizations. The majority of the peasantry held the Unionists responsibl. from the loss of Ottoman territories.

General Mustafa Kemal was sent to the Black Sea coast of Anatolia to supervise the disbanding of the Turkish forces as the Inspector-General of the Third Army. The Sultan in Istanbul was against any nationalist ideology or popular revolt and he ordered Mustafa Kemal to restore order in the Samsun area of the Black Sea coast. Here conflicts between Muslims and Christians were growing where semi-military bands of be $h$ Turks and Christians had been operating in the area for some time. Mustafa Kemal wa.s to supervise and disarm the remaining Ottoman forces. Instead he aimed to organize the popular reactions in Anatolia and to raise an army.

Mustafa Kemal managed to convince the military commanders in Anatolia to unite against the Istanbul government. With this alliance between Mustafa Kemal and the commanders in Anatolia, the Istanbul government lost its control over the army. As Selek points out, Mustafa Kemal, who was appointed by the Sultan as the 'military inspector'. had not only military responsibilities but civilian as well to restore order. Mustafa Kemal used this advantageous position to inform all civilian offices about the national movement 
forcing the Ottoman administrators to select between the Ottoman government $v$ the Nationalists in Anatolia (Selek 1963, p. 47). In those provinces which were governed by administrators loyal to the Istanbul government the National Forces and the Societies for the Defense of Rights faced considerable opposition. The Nationalists took measures against thoss: 'valis' (governor of a province) and 'mutasarrifs' (governor of a 'liva' or 'sancak' which was an administrative district smaller than a province) who opposed them. They were, with the aid of the army, withdrawn from their offices and replaced by new administrators who supported the nationalist movement against both the Allied Powers and the Ottoman government (Selek 1963, p. 48).

Under Mustafa Kemal's leadership two major successive congresses were held that took decisions regarding the unification of the nationalist movements. The congresses set down the aims of the struggle for national liberation against the occupiers. The Erzurum (July 10, 1919) and Sivas (September 4, 1919) Congresses of the Defense of Rights Associations had historic significance for the national liberation movement. Before the Erzurum Congress the Sultan, who was opposed to any movement against the Allied Powers, revoked Mustafa Kemal's status as the Inspector-General, and Mustafa Kemal, in response to the Sultan, resigned from the army. During the Erzurum Congress Mustafa Kemal was elected chairman. The Congress also elected a Representative Committee (Heyet-i Temsiliye). After the Congress Mustafa Kemal and the delegates remaining in Erzurum wrote letters to the tribal chiefs, to sheiks, and to the notables in the towns asking for their help and cooperation (Selek 1963, p. 230). 
The Sivas Congress had more historical significance than the former one since it unified all local resistance movements against the occupiers at the national level. Now the Nationalists were unified in one center in their struggle against both the Allied Powers and the Ottoman government. The Sivas Congress accepted all the resolutions of the Erzurum Congress. Moreover, the 'Association for the Defence of the Rights of Eastern Anatolia' now became the 'Association for the Defence of the Rights of Anatolia and Rumelia' (Anadolu ve Rumeli Mudafaai Hukuk Cemiyeti) unifying all of the local Associations for the Defence of Rights. The Representative Committee headed by Mustafa Kemal, which began to act as the only real government, was now permanently established.

In October 1919 Salih Pasha, the Minister of the Navy, was sent to Amasya to negotiate with Mustafa Kemal. A protocol, known as the 'Amasya Protocol', was signed which was based on the Erzurum and Sivas Resolutions. With this protocol the Ottoman government recognized the Representative Committee and the Association for the Defence of the Rights of Anatolia and Rumelia. In the following months Mustafa Kemal, for security reasons, decided to move his headquarters from Sivas to Ankara (December 1919).

A cryptic document, released on January 28, 1920, known as the National Pact, declared a programme for the indeperiderice of the country. The National Pact was adopted by the Sultan's Parliament in January 1920 and the Allied Powers were notified of the demands of the Representative Committee. With these developments the nationalist movement in Anatolia began to gain legitimacy in the eyes of many, both within the country and abroad. However, partly in response to these developments, the British forces occupied Istanbul on March 16, 1920. With General Wilson's order, who was the Allied 
Commander, Young Turks and some of sisir supporters were arrested and deported to Malta. There were a number of deputies, such as Rauf Bey (Orbay)[4]. among those who were arrested. The same day that Istanbul was occupied, Mustafa Kemal, as the head of the Representative Committee, sent an instruction to all Turkish Civil and Military Authorities calling for the protection of the interests of the country against the invaders. Following Istanbul's occupation the Ottoman government in Istanbul held its last session and prorogued itself on March 18, 1920. The Ottoman government was dissolved on April 11, 1920 by the Sultan.

On April 23, 1920 The Grand National Assembly gathered for the first time in Ankara despite the existence of a legitimate parliament of the Ottoman Empire in Istanbul. Before dealing with the structure of the National Assembly I briefly refer to the major events which took place throughout Anatolia in 1920, which was a critical period in Turkish history.

As Aybars notes, one of the biggest problems inherited from the Ottoman Empire was social banditry. Until the establishment of the Turkish Republic, brigands and military deserters were part of the social structure like any other social class since they received considerable support from the peasants and since the central authorities did not have the power to control their activities. Brigands were all around the country and they controlled entrance to the cities. Local leaders had to negotiate with brigands; this became regarded as normal by everyone (Aybars 1988. p. 218). During the independence movement, which was the first phase of the state-building process, brigands were a real threat to unification and centralization at the national level since they were able to act freely 
against the Nationalists who were trying to organize and coordinate the local movements of resistance against the occupiers. Social banditry served both as an 'individual' and as a 'collective- organized' form of resistance to state authority. Also during the formative years of the state, at certain times and places, it merged with other types of organized movements such as those making ethnic and religious demands on a local basis.

In addition to social banditry, military desertion constituted another major source of threat to the state-makers who often had links to the bandits. Military desertion, too, was a form of resistance which also served a new purpose to resist state-building since a large number of deserters joined hands with the bandits or with the peasants that revolted against the Nationalists. Desertion from the army began during World War I. Initially military deserters were war resisters and they were motivated more by individual reasons such as saving their lives or supporting and protecting their families against the robbers. Especially those living in Western Anatolia were deserting with their rifles in order to protect their families against Greek occupation. However. by the end of World War I, military desertion evolved into a inore organized form of resistance as the confrontation between the deserters and the state became more severe. Military deserters, who formed strong bands of various sizes, were a real threat first to the Ottoman government and later to the Ankara government. Most of the military deserters joined the bands of brigands who were involved in robbery and pillage. Also they participated in local revolts. The army, as the central institution of the state, faced this initially unorganized form of resistance as a serious challenge to its existence as the number of deserters continued to 
grow and as they developed more organized forms of resistance against the establishment of a regular army.

Mustafa Kemal's aim was to establish an organized national (conventional) army in order to achieve national independence. However, the large number of military deserters, brigand bands, and armed militia bands as part of the Nationalist guerilla forces were standing in the way of establishing a national army. Until the national army was established in 1921 the armed militia bands, together with the brigand bands supporting them, were the only forces that Mustafa Kemal could rely on in his struggle for national liberation.

During the time the Representative Committee was formed numerous internal upheavals were witnessed in Anatolia which threatened the establishment of a central authority. These rebellions which occurred between the years of 1919 and 1921 refiected the reactions of those groups supporting the Sultan-Caliph (Aybars 1988, p. 16).[5] The Ottoman government formed its own army against the nationalists, known as the Army of the Caliphate (or the 'Disciplinary Forces') (Kuvayi Inzibatiye) in April 1920. Criminals, vagrants and unemployed persons in Istanbul were enlisted in this army, which was supported by the British and Greek forces (Smith 1959, p. 34). The religious leaders (hocas) cooperated with this army, and provoked the people in Anatolia to rise against the Nationalists. Moreover, Mustafa Kemal and other leaders of the nationalist movement were sentenced to death in absentia by a court martial in Istanbul. 
The signing of the Sevres Treaty after the establishment of the National Assembly in Ankara further contributed to this anarchic situation in Anatolia. For the Treaty of Sevres. signed between the Ottoman government and the Allied forces. laid the grounds for the establishment of an independent Kurdish state as well as the establishment of an independent Armenian state. Many rebellions occurred in Anatolia after the signing of the Treaty of Sevres; they were organized by the leaders of the Kurdish tribes who demanded independence from Ankara government (Mumcu 1991). The Circassians and the Greeks of Turkish nationality (known as the Rums), too, were involved in a number of revolts which took place during this period. At the same time Eastern Anatolia witnessed severe guerilla wars between the Turks and Armenians which continued until the end of 1920.

The day before the opening of the Assembly, on April 22, 1920. Mustafa Kemal announced that all civil and military officers were to be appointed by the Assembly in Ankara as of April 23, 1920 (Selek 1963, p. 48). In the meantime the deputies gathered in Ankara for the opening of the National Assembly. These deputies can be divided into three groups: (1) 92 deputies who transferred from the Istanbul Parliament, (2) 14 deputies who returned from exile (one from Greece and 13 from Malta), and (3) 232 deputies who were elected after the March 19.1920 announcement (Mazici 1984, pp. 2526).

The Grand National Assembly gathered in Ankara on April 23, 1920. The official British occupation of Istanbul on March 16, 1920, played a key role in the establishment of a separate govemment in Ankara. Many who had previously opposed the Nationalists gave 
their support to them after the British occupation. Later with the signing of the Treaty of Sevres by the Ottoman government on August 10,1920 the Nationalists position against the Ottoman government was further strengthened. For with the Treaty of Sevres the Turks had agreed to give up parts of Anatolia to Greeks and to Armenians.

In response to the initial rebellions which were against the nationalist movement. the Assembly passed an act relating to crimes against the country (the Law Against Treason) (Hiyanet-i Vataniye Kanunu) on April 29, 1920. According to this Act those found guilty of participation in a revolt faced execution. The Civil Courts and the Councils of War (harp divanlari) were not functioning efficiently, and this promoted the establishment of the extraordinary tribunals known as Courns of Independence. The Courts established during the period 1920-1923 are generally known as the first Courts of Independence. Those established in 1926 after the Sheikh Sait Revolt are known as the second Courts of Independence.

The Courts of Independence, which were established all around the country, functioned in the name of the Turkish Grand National Assembly. The judges were elected from among the deputies of the Assembly. In this way, the deputies not only held legislative and executive power but also exercised judicial power. The main motive behind the establishment of these courts was to find a solution to brigandage and military desertion since this was necessary to reestablish state authority. The Courts of Independence became effective means of preventing desertion from the army (some of these deserters were joining the army of the Caliph-Sultan) and brigandage, and in providing the needed manpower for military service (Aybars 1988).[6] 
After the Grand National Assembly was constituted in 1920 diverse communist movements became active in Anatolia. One of the most influential organizations established in Ankara was the Green Army (Yesil Ordu) which later joined with the forces of Circassian Ethem.

Besides the Green Army there was an illegal Turkish Communist Party formed under the influence of the Soviet Revolution. This illegal Communist Party gained legitimation with the formation of the People's Participation Party in Turkey (Turkiye Halk Istirakiyun Firkasi) in December 1920 (Kili 1983, p. 93; Aybars 1988, p. 60). This party was formed by the members of the Green Army and the illegal Communist Party: it became most active in Ankara and Eskisehir. In order to control these organizations. Mustafa Kemal initiated the establishment of the official Turkish Communist Party which was formed by his close friends in October 1920. The founders of the party were all influential deputies with no real connection to the communist movement. After the Treaty of Moscow was signed in March 1921, Mustafa Kemal ordered the termination of the activities of these organizations just before he formed his own group (the First Group) in the parliament. The Green Army and other similar organizations were eliminated by the Courts of Independence. The members of these organizations were either sentenced to death or to prison, the latter were later released under a general amnesty in September 1921 (Aybars 1988, pp. 63-64).

The first Assembly was a heterogeneous body. Mustafa Kemal's friend Kilic Ali who participated in both Courts of Independence as a judge describes the Assembly as follows, 
The First Grand National Assembly was an utterly different world. There you could find people who had pulled on jackets over their loose robes, people ranging from a number of bigoted individuals who wore the fez to Kurds and Circassians wrapped up in their national costumes, astrakhan-wearing nationalists, the doctor. pharmacist, commander, ulema, judge, dervish, sheikh. lawyer, telegraph officialpasha. bey, efendi, aga, haci, hoca, of every sort, from every occupation. all the types of a society (Frey 1965. p. 306).[7]

Although the first Assembly was a heterogeneous body the conservative tendency among its members was visible. Selek refers to a motion offered to the Assembly on April 29. 1920 by two deputies from Bursa and Sinop with regard to the abolition of the 'fez'. In the motion it was argued that the importation of the fez from abroad had been a financial burden to the government for years. It was also argued that the fez originally was a Greek headgear. Based on these arguments it was proposed that fez should be replaced by 'kalpak' (a headgear shaped like a fez but made of fur or astrakhan). While many deputies applauded this proposal the majority opposed, arguing that the fez was a symbol of Muslim identity among Muslims all over the world. When the motion was put to a vote it was rejected by the majority. Selek notes that no one had the courage to defend the abolition of the fez during these discussions (1963. pp. 294-295).

The differences among the deputies were soon organized into opposing factions by the end of the year 1920, representing competing ideological trends which became much more apparent during the constitutional debates. The major ones were the Solidarity (or Union) Group (Tesanut Grubu), the Independence Group (Istiklal Grubu), the Defense of Rights Faction (Mudafa-i Hukuk Zumresi), the People's Faction (Halk Zumresi), and the Reform Group (Islahat Grubu). The principal trends took place in the old groupings of Islamists, Westernists, and Turkists (Berkes 1964, p. 436). There was a split between the 
'Eastern ideal' (Sark Mefkuresi) and the 'Western ideal' (Garp Mefkuresi). The Eastern Ideal implied Turkism. antagonistic both to the 'West' and to the 'Soviet Union'. The Western Ideal saw 'the West' as the model to be followed in the formation of the Turkish state and government.

This split was reflected in the existence of two opposing groups, the First Group and the Second Groul. The First Group, representing the 'Westem Ideal', was organized by Mustafa Kemal and it took the name of the Defense of Rights Group on May 10, 1921. The members of the Second Group, formed by Mustafa Kemal's opponents, were the supporters of the Sultanate-Caliphate and most of them were the old Unionists. However, as Kurat notes. the Second Group was not a homogeneous group composed only of the old Unionists (1991, p. 87). The Anatolian notables were also part of this group. The Kemalists and the Unionists differed on matters like nationalism and Pan-Islamism. While the First Group wanted to secure unity among the Turis in Anatolia and Thrace, the Unionists, following Enver Pasha's Islamic doctrine, desired territorial expansion to include the former Muslim provinces of the Ottoman Empire. Also the Unionists, although they preferred a form of government similar to the European model, wanted to protect the Caliphate permanently. Mustafa Kemal's group. on the other hand, was strictly against both the Sultanate and the Caliphate (Kurat 1991, p. 87).

As Mazici notes, the majority of the members of the Second Group were from regions which were not occupied by the Allied Powers, such as the North Coast and Northeast Anatolia (1984, p. 60). However. Tuncay notes that the great majority of the members of the Society for the Defence of the Rights in Anatolia and Thrace and many deputies of the 
Assembly were also Unionists (1992, p. 42). The Second Group questioned the extent of the authority of the Council of Ministers. They argued that if too much power was given to the Council of Ministers this would stand in the way of establishing a better administrative system. Although this system, as proposed by the Second Group, would give more power to Mustafa Kemal it was not welcomed by the First group (Adivar 1987. p. 221). The Second Group became very powerful during 1921. Many of Mustafa Kemal's former friends, who were also revolutionary heroes, joined this group.

In addition to this division within the Assembly Mustafa Kemal faced opposition from the religious groups. The struggle between the Kemalists and the supponers of the SultanateCaliphate became more manifest during the discussions over the constitution.

Although there was a government in Ankara. Mustafa Kemal represented only one of those competing power groups such as the Seriatists (Sharia, Muslim divine law), those supporting the Caliphate, Panislamists, Panturanists, Liberals, Unionists, and Socialists. Mustafa Kemal described the atmosphere in the Assembly soon after it was opened and pointed out the most delicate question at that time.

It was a question of acknowledging the collapse and the abolition of the Ottoman rule Caliphate. It meant the creation of a new State standing on new foundations. But to speak openly of the position as it revealed itself might eventually jeopardise the goal we were aiming at. For, the general opinion inclined to the idea that the attitude of the Sultan-Caliph was excusable. Even in the Assembly during the first months there was a tendency to seek communion with the seat of the Caliphate, a union with the Central Government" (Ataturk 1927, p. 380).

In Mustafa Kemal's view, the fundamental principle in the organization of the new government was the unity of powers which was based on the principle of the sovereignty 
of the nation (as opposed to the traditional regime based on the absolute rule of the SultanCaliph) (Ataturk 1927, p. 381). Mustafa Kemal submitted a project to the Assembly which outlined the principles of the new regime. called 'The Program of Populism'. Based on this program a committee drafted the new constitution. Despite the growing protests of the clericals, after a five-month struggle. the new constitution (Teskilat-i Esasiye Kanunu [the Law of Fundamental Organization]) was adopted on January 20.1921 and the nation was declared sovereign.

The conservative forces in the Assembly continued to grow during its second year. As Berkes points out.

Not only drinking and gambling, but also cand playing and backgammon were prohibited by law. Although these laws were not passed without a struggle between the conservative and progressive sectors of the Assembly, they did pass. Furthermore, all bills had to pass the Seriat Committee in addition to the usual parliamentary committees concerned. And the clericals had more religious 'reforms' up their sleeves, such as prohibiting the unveiling of women and the wearing of luxury clothes, and even making polygamy compulsory (1964, p. 448).

It was under these circumstances that the First Partiamentary Group representing the Society for the Defence of Rights was formed by Mustafa Kemal (on May 10. 1921) against the growing conservative reaction. ihe First Group formed the Republican Party on September 9, 1923. The Second Group was nutnumbered in the Assembly after 1921. but its influence continued to increase since they received considerable support from the groups outside the parliament.[8]

The War of Independence ended on September 9, 1922. On November 1, 1922, Mustafa Kemal proposed the abolition of the Sultanate to the Assembly. Mustafa Kemal's reaction 
to the opposing clerical members of the Seriat Committee is worth mentioning for the bill for the abolition of the Sultanate was ready in a few hours after his speech. As Berkes quotes from the 'Speech'.

They claimed by their well-known sophistry that the Sultanate could not be separated from the Caliphate...Finally I took the foor and, climbing on top of the table before me. I made the following declaration: 'Gentlemen, sovereignty ras never been given to any nation by scholarly disputation. It is always taken by force and with coercion... The Turkish nation has now taken back its usurped sovereignty by rebellion. This is a fact. The question facing us now is not whether or not this sovereignty will be left to the nation. but the simple matter of declaring that which is a fact...If those who have assembled here recognize this natural fact like everyone else, all will be fine. If not, what is natural will happen anyhow, with the only difference that a few heads will probably have to be chopped off (1964, p. 450; Ataturk 1927, p. 577).[9]

The bill passed the same day (on November 1, 1922) and the Sultanate was abolished.

The Treaty of Lausanne was signed on July 24, 1923 which was an international recognition of the establishment of the Turkish state on new grounds. The winning of the war provided both extemal and internal legitimation to the newly established state. However, at the domestic level, the constitution of the new state was not yet complete.

In December 1922 Mustafa Kemal announced that he wanted to form a political party from the Defence of Rights Group. His desire was enacted into law at the Congress of the League for the Defense of Rights, held in April 1923. The Defence of Rights Group 
published a manifesto which is known as the 'Dokuz Umde' (Nine Principles). This manifesto, as the programme of the Defence of Rights Group. was a repetition of Mustafia Kemal's views on popular sovereignty and representative government. and the atolition of the Sultanate as an unalterable decision (Tuncay 1992. p. 52). The Defence of Rights Group won the elections of June 1923 with a large majority. It was after these elections that the republic was proclaimed on October 29. 1923. and Mustafa Kemal was elected the President. The new cabinet formed after the elections was headed by Ismet Pasha (Inonu). The Second Group, which numbered about forty, did not return to the Assembly after the elections. Tuncay points out that, with these elections not only the members of the Second Group but also the former influential Unionists lost their basis of power ( 1992 . p. 55). However. new groups and parties were formed as Mustafa Kemal proceeded with his plans. I discuss these developments below.

The Istanbul press had opposed Mustafa Kemal and the nationalist movement from the beginning. Istanbul newspapers did not support the proclamation of the republic mostly because they were the strong opponents of the Unionists. The publication of most of these and other newspapers were prohibited permanently after the 'Law for the Maintenance of Order' (Takrir-i Sukun) passed the Assembly in 1925 following the Sheikh Sait Rebellion (Aybars 1988, p. 280; Mazici 1984, p. 153).

The struggle between the secularists and the supporters of the Caliphate became more severe after Mustafa Kemal's success in the elections. At the beginning of the Independence War Mustafa Kemal organized the nationalist resistance movements by making religious appeals to the leaders in the periphery. He convinced the Kurdish 'beys' 
(chief) and 'sheikhs' (who supported the Caliphate) to support himself (Kabacali 1991.pp. 29-30). Since the seventeenth century many officials took up brigandage and local. village-based militias were founded and led by 'Kadis' (Moslem judges of towns or villages) for protection azainst these bands of brigands. During the War of Independence Mustafa Kemal benefited from these local organizations in Anatolia, this was one of the keys to his early success (Mardin 1971, p. 204). Before the opening of the National Assembly in Ankara Mustafa Kemal contacted the 'muftis' (doctors of Islamic Law). 'kadis' (Muslim judges), and 'ulemas' (the clergy) from all parts of Anatolia who gave their support to the national movement. This gave Mustafa Kemal much courage in his attempt to gather the new Assembly.

Not all Anatolian religious leaders were against the nationalist movement. Many religious leaders, as well as influential sheiks, supported the National Forces. They actively participated in many political gatherings. As Selek notes, some of the Societses for the Defence of National Rights were led by religious leaders, and there were sixty men of religion in the First Assembly (1963, p. 65). However, the great majority of the counter-revelutionary movements were religious crusades organized by the religious leaders in Anatolia.

The principal difficulty for the new regime was to resolve the age old tension between Westernization and the religious basis of traditional society and state. The process of modemization, which started with the military reforms in the eighteenth century, came to a point where secularism was seen as the most necessary step for the establishment of a Westem type of society. In general, the adoption of the principles of Western civilization 
provided the grounds for a break from the 'traditional' society. and secularism was the most important step taken in this direction.

After winning the war, and despite the religious support Mustafa Kemal received from the clericals, his next step was to abolish the Caliphate which aroused interest beyond the borders of Turkey. Two Indian dignitaries, the Agha Khan and Ameer Ali, sent a letter to the Turkish government asking for the maintenance of the Caliphate, which they saw as the basis of unity among the Muslim population of the world (Aybars 1988, p. 225; Berkes 1964, p. 458; Tuncay 1992, p. 75)). The copies of this letter were published in Turkish newspapers before the government received it. This incident became the basis of reestablishing the Courts of Independence on December 1923. The owners of the newspapers and their directors were arrested, and they were judged by the Istanbul Court of Independence. These developments eased the abolition of the Caliphate.

It was important for Mustafa Kemal to cut off Turkey's links with its Islamic past. He said in his 'Speech', "I helped the people to understand that neither Turkey nor the handful of men she possesses could be placed at the disposal of the Caliph so that he might fulfil the mission attributed to him, namely, to found a State comprising the whole of Islam. The Turkish nation is incapable of undertaking such an irrational mission" (Ataturk 1927,p. 592). The bill abolishing the Caliphate was passed on March 3, 1924. This date marks the end of the Ottoman dynasty (the last Caliph was Abdulmecit II). The same year the seriat courts were also abolished by law. According to Aybars, in the short run, there were nnly a few individual resisting to the abolition of the Caliphate which were repressed by 
effective measures taken by the government (1988, p. 255). In the parliament, however, those opposing Mustafa Kemal joined hands. I discuss these developments below.

\subsection{Formation of the National Assembly and its Aftermath (1923-1935)}

After the Republican regime was proclaimed in 1923 the Turkish state-builders did not remain at the level of establishing new institutions. They were involved in a transformative cultural-ideological process. In this context. resistance to the Turkish Revolution, which had a cultural overtone, differed from the earlier forms of resistance.

Between the years 1923-1938 many other reforms were made to complete the Turkish Revolution. These reforms extended beyond building new institutions. The aim was to transform the existing cultural and ideological structures and to homogenize the society. Even the personal domains such as family, inheritance, and dress were under consideration. Modernization and Westernization were part of the policies of the revolutionaries.

Two important bills were passed following the abolition of the Caliphate. The first abolished the Ministries of Seriat and Evkaf (pious foundations). Another closed the medreses (Moslem school of theology), unified education under the Ministry of Education, and abolished the religious orders (tariqas) and their cloisters (in 1924). On November 3, 1928, the constitution was further secularized with the abandonment of the article stating that Islam was the state religion. 
In 1925 the Hat Law passed which initiated numerous resistance movements among the conservatives. In 1926 the new Civil Code, adapted from the Swiss Civil Code, was accepted in the National Assembly which replaced the Seriat as the law of the state. As Berkes points out,

The aim of the makers of the Code was not to establish and regulate the civil relations of the people according to existing customs and mores, or religious provisions. On the contrary, it was to shape these relations according to what the makers of the Code believed they should be...it was not a codification bringing together different traditions for the purpose of their reconciliation, but rather one establishing a new system to the exclusion of the provisions of the religious and customary legal systems (1964, p. 471).

Latin script was adopted in 1928 and teaching of the Arabic script in unauthorized schools and its use in public affairs was also prohibited. The hat reform and the adoption of the Latin script were seen as an attack on the national mores and thus aroused anger among certain segments of the population.

In 1934 full political rights and duties were given to women by law. The same year. The Law of Family Names was adopted. Also in 1934 the use of the terms such as 'haci', 'hafiz', and 'molla' as religious titles in official use was prohibited. Later, in 1938, the formation of societies and political parties based on religion, sect, and 'tariqa' was prohibited as well.

All of these reforms initiated a cultural revolution. Not only did the conservatives and the Seriatists but the Turkists as well reacted to these reforms in terms of protecting the essentials of the Turkish culture. 
I now continue with a brief overview of the years following the establishment of the Republic focusing on local revolts and resistance movements. Some of these revolts stemmed from the reactions to the reforms outlined above.

Eighteen revolts took place between the years 1924-1938. Only one of these revolts occurred in Western Anatolia. The remaining revolts took place in the Eastern provinces and, except for one, they were all instigated by Kurdish tribes and their (religious) leaders (Tuncay 1992, pp. 126-127; Oran 1990, pp. 194-195).[10] The Sheikh Sait revolt, which occurred in 1925 and expanded to a large area, had very important consequences for the future of the new regime. With this revolt the 'Law for the Maintenance of Order' was proclaimed and the Courts of Independence set up in the east and in Ankara took effect as extraordinary measures.[11] The convents of dervishes were closed, their associations were disbanded, and also their meetings, ceremonies, and special garbs were banned. The press was also under attack.

It was after the Sheikh Sait Revolt that the symbolic hat reform occurred in 1925, which initiated rebellions and new forms of resistance movements. These movements of resistance came from various parts of Anatolia. The fez was a symbol of Muslim identity. In this sense the adoption of the hat was treated as a very serious attack on the existing mores of the society. As Berkes notes, "For a century the fez had symbolized fears, superstitions, and prejudices. When a man clapped anything, however ridiculous, on his head and called it a hat, he was, in effect, declaring his freedom from all inhibitions" (1964. p. 474). Those who resisted or revolted against the wearing of the hat were judged by Ankara Court of Independence and many people were sentenced to prison and some 
were sentenced to death (Aybars 1988, pp. 406-418). Berkes notes that some even left the country to protest the wearing of the hat (1978. p. 540).

Wearing the veil was not prohibited by law most probably to avoid further opposition (Tuncay 1992, p. 150-151). Nevertheless all women were encouraged to unveil and participate in public life. These efforts successfully transformed the border between the public and private lives of Turkish women. Gole refers to Norbert Elias's concept of 'civilization', and argues that the efforts to participate in Western civilization was broad enough to accept Western 'life styles' even at the most personal levels (Gole 1991, pp. 5052). I quote from Kinross at length since it supports the argument above. As Kinross writes,

Soon after his visit to Kastamonu Kemal proceeded in 1925 to the more sophisticated city of Izmir (Smyma). Here he presided over an entertainment which was in effect the first Turkish ball. Only Moslems and their ladies were invited. An orchestra played Western music, and they were expected to dance together -- an ordeal which they faced with reluctance, even after the Gazi himself had opened the ball by performing a correct foxirot with the Govemor's daughter. Never until this moment had a Turkish woman, in her own country, danced with a man in public.

In Istanbul the habit soon caught on. Elsewhere Kemal had to use all his talents of persuasion to make dances an accepted social function. At first there was little mixing, the ladies remaining in one corner, the men in the other, reluctant to introduce their wives to their friends...club dances on Fridays became a habit in Ankara and the main provincial centres, and a new profession, that of the dancingmaster, began to flourish (1965. pp. 420-421).

However, despite these developments, unveiling of women, too, initiated unorganized resistance movements in various parts of the country. Those who resisted the unveiling of women or the Hat Law presented themselves as defending Islam against secularism. Based on religious values these movements were not similar either to military desertion 
or to social banditry as a form of resistance against state authority. These new acts of resistance, compared to the previous ones, were highly symbolic, and they had a more clear political standpoint.

What follows is the developments within the Assembly and the establishment of the two opposition political parties.

After the abolition of the Caliphate a series of reforms were made to strengthen the power of the new government. The office of 'Seyh-ul Islam' and the Ministry of Seriat were abolished. Also the religious schools and the Seriat courts functioning on the basis of the Holy Law were abolished. Based on these developments the republican constitution was adopted by the Assembly on April 20, 1924. This constitution was based mainly on the 1921 Constitution. However, to soften the blow on the Caliphate the article of the constitution stating 'The religion of the Turkish state is Islam' was retained without modification. It was dropped in 1928, and the principle of secularism was added to the constitution only in 1937.

After these developments, and following the elimination of the communist organizations, Mustafa Kemal's opponents formed the Progressive Republican Party (Terakkiperver Cumhuriyet Firkasi) in 1924 . In reaction to this party's calling itself 'Republican', the People's Party changed its name to Republican People's Party. Immediately after its establishment questions were raised in the press with regard to this new party's link to the old Unionists (Tuncay 1992, p. 103). The Progressive Party was organized by Ali Fuat 
Pasha (Cebesoy). Mustafa Kemal was firmly opposed to this new party since he saw it as a serious challenge to parliamentary unity.

The new party announced its loyalty to the Islamic religion and attracted many supporters especially in the Eastern cities of Anatolia (Tuncay 1992, p. 108; Kabasakal 1991.p. 115). Also the Istanbul press supported the Progressive Party to a considerable extent (Tuncay 1992, p. 107).

The Progressive Party was dissolved by the government on June 3. 1925 based on the claim that some of its members had links with the Sheikh Sait Revolt. It was also argued by the government that the penetration of the Muslim clerics into the party's ranks was a threat to the country's unity, therefore it had to be banned. From then on the Republican People's Party was the only party in the Assembly until 1930.

In June 1926 a plan to assassinate Mustafa Kemal was discovered and the conspirators were arrested. Among them were the members of the old Progressive Party and the old Unionists, some of whom were sentenced to death by the Ankara Court of Independence. These developments marked the end for the Unionists. However, in Tuncay's view, since the Party of Union and Progress was based on the model of masonic organizations, being a 'Unionist' could be considered as a lifetime commitment (1992, p. 164). Therefore, it can be argued that Unionism continued to live in Turkey even after the mid-twenties.

According to Aybars, the period between $1925-1927$ was very important in terms of the establishment of state authority, and the Courts of Independence played a major role during this transformative period which were abolished in 1927 (1988, p. 481, 483). 
On August 12, 1930 a new party, called the 'Free Party' (or the Liberal Republican Party) (Serbest Cumhuriyet Firkasi), was formed which survived only a few months. The party was founded by Mustafa Kemal's close friend Ali Fethi (Okyar), known as a liberal (and a free mason as argued by some), who resigned during the Kurdish Revolts. Tuncay argues that this party was an 'artificial' opposition party since its formation was requested by Mustafa Kemal. Mustafa Kemal's aim was to increase political activity within the Assembly by establishing an opposition party. Tuncay claims that one possible motive to form such a party was to gain the respect of Western countries (1992. p. 245).

However, the Free Party received considerable public support from the western regions of the country, especially from Izmir and Istanbul. Many members of the 'Turkish Heart' organization (Turk Ocagi) joined the party (Kabasakal 1991, p. 122).[12] In the local elections of October 1930 the Free Party showed considerable success, despite being a newly formed party. Due to its growth, the Free Party was induced to abolish itself on December 18, 1930. In Tuncay's view, the new party proved itself to be a threat to the leadership of the Republican People's Party, therefore forced to dissolve itself (1992, p. 270). Following these developments the single party rule of the Republican People's Party continued for another 15 years.

Here I refer to the 'Turkish Hearts' (Turk Ocaklari), and to the transformation of the 'Turkish Hearts' into 'People's Houses' (Halk Evleri) which took place after 1930.

The Turkish Heart organization was founded in 1912 with the aim to spread Turkism. This nationalist organization, in order to achieve its goal, opened many clubs which were 
named the 'Turkish Hearts'. In the meantime there was a joumal called the 'Turk Yurdu' (The Turkish Homeland), which was established in 1911. This journal. 100. was defending Turkism. As Lewis argues, referring to the memoirs of Halide Edib (Adivar). "The Turkish Hearts increased rapidly in number, not only in Istanbul but also in many provincial centres. Many prominent literary figures joined the movement, and contributed both to its journal and to the activities of its branches. In these centres, incidentally. mixed audiences met for the first time, and women were able to make their first appearance on a public platform. both as speakers and as performers in amateur theatricals" (1968, p. 350).

The Turkish Hearts were reestablished on April 23, 1924. During the Republican period the Turkish Hearts were the main centers which continued to spread out the ideology of Turkism of the former Union and Progress Party. Mustafa Kemal initiated the transformation of the 'Turkish Hearts', which he saw as centers opposing the present regime, into the 'People's Houses'. These newly established 'People's Houses' functioned as the semi-political local branches of the Republican People's Party spreading out its cultural policies throughout the country (Kabasakal 1991, p. 129). The People's Houses also introduced many social activities, such as ballroom dancing, dramatic representations, and new political rituals such as the welcoming of bureaucrats and the celebration of national days (Ozturkmen 1994, p. 160). According to Tuncay, the formation of the 'People's Houses' marks the beginnings of the establishment of the single party rule in Turkey (1992, p. 295). Until the foundation of the Democratic Party in 1946. there were no serious challenges to the ruling of the Republican People's Party. 


\subsection{Conclusion}

Up to this point. covering the years from 1919 to mid-1930s. I have outlined the major tensions and power struggles between different social groups which did not have a clear class characteristic. The Turkish Revolution is a name given to a period of Turkish history of indefinite length during which the political system was transformed (Mardin 1971. p. 198). In this sense. the Turkish Revolution can be seen as a gradual process of economic and social transformation, and can be traced back to the to the Young Turk Revolution of 1908. Nevertheless, the Turkish War of Independence is generally accepted as the first stage of the Turkish Revolution in terms of the establishment of the modern Turkish nation-state.

In this concluding section I highlight the characteristic aspects of the process of Turkish nation-state building. The establishment of the nation-state. including the period of the Independence War, was at the same time a revolutionary process since the Turkish Dolitical and social system was entirely transformed into a modern nation-state. I use the term 'revolution' not merely to refer to a change in the system of ownership, production and distribution. A revolution can be purely political with important social consequences. In other words, following Moore, it is necessary to distinguish between revolutions from 'above' and revolutions from 'below' (Moore 1974). Bourgeois revolutions, which are revolutions from below, stems from economic transformation paralleled by social and political transformation. The Turkish Revolution, which was a revolution from above. was mainly a political revolution and it was accompanied by a project that aimed at 
changing the whole fabric of the Turkish society. Whether or not this project has theen successful is open to discussion.

The political and social modemization of Turkey was the target of the revolution and this is what characterizes the transformative process in Turkey. In contrast wo West European countries capitalist transformation in Turkey was initiated after the new state was established. In this respect it was not a bourgeois revolution as was the calse in Western Europe. The economic classes were embryonic in Turkey. As Mardin puts it. "in Turkey the struggle was an intra-bureaucratic one...Except for a small cone on top of the hierarchical pyramid. not much of an adjustment of class relations was involved. At most it was a new generation of bureaucrats who were replacing an older one" (1971, p. 199). In this respect the revolutionaries did not differ much from the Young Turk leaders in their aims. As Lewis notes. "even by the early twentieth century the Young Turk revolutionaries. in their discussions and arguments both before and after the Revolution. devote comparatively little attention to economic matters" (1968. p. 458). To reform and preserve the state was the main motive for the Young Turk leaders who are regarded as the founders of the republican Turkey. This motive was, at the beginning. equally important for the new bureaucratic elite which had led the Turkish Revolution.

In the course of the revolution the leaders of the movement moved towards not only preserving the state but changing the whole fabric of the Turkish society. In this respect this transformative process was revolutionary since it resulted in the establishment of a modem nation-state. As Mardin puts it. "the Turkish Revolution was not the instrument 
of a discontented bourgeoisie, it did not ride on a wave of peasant dissatisfaction with the wocial order. and it did not have as target the sweeping away of feudal privileges. but it did take as a target the values of the Ottoman ancien regime. In this sense it was a revolutionary movement" (1971. p. 202). Ottoman society was transformed from an Islamic Empire into a secular Turkish nation-state. In addition Islam was replaced with the ideology of nationalism.

The Turkish Revolution was a reaction both to foreign invasion and to the multi-ethnic and multi-religious Ottoman imperial dynasty. I argue that the Turkish Revolution cannot solely be explained as the natural outcome of the process of Westernization or modernization. Neither can it be totally separated from the Western model of nationbuilding by emphasizing Islam or the distinctive cultural system prevalent in Turkey. The internal dynamics of the Ottoman society, and the 'West', both as a source of admiration and as a threat to the traditional ways of life. gave the Turkish Revolution a distinctive characteristic. I elaborate on these issues further in the following pages.

It is necessary to look beyond the economic classes since the process of 'class formation' is different than the process of 'state-formation'. The focus of this study is on the process of staic-formation. In this respect, religious and ethnic conumunities, and cultural-social groups are extremely important for a deeper understanding of the state-building process in Turkey. It is in this context that I will examine. in Chapter Four. various forms of resistance where the relationship between the state and different ethnic communities and cultural groups became materialized. 
It is necessary to make a few general remarks about the class characteristic of the Turkish Revolution before looking at the process of state-formation from a cultural perspectuce that involves groups other than economic classes.

In the Ottoman Empire economic affairs were mainly left in the hands of the Christlan and Jewish minority groups which were excluded from the political realm. There was no Muslim bourgeoisie. In this economic system the Christian bourgeoisie functioned as a commercial class with no political power. In Keyder's words. "the Christian bourgenisie attempted to stage their struggle in the inter-state theatre. not principally through s(x:ial demands designed to favour their access to political authority, but through demands if ethnic and religious autonomy. From this point of view. the Christian commercial bourgeoisie never entertained the option of becoming a class for itself through exercising influence over the state" (1988, p. 200). In other words, the Christian merchants hixd always rejected the Ottoman state as a legitimate field of political struggle. Hence the Turkish Revolution did not develop as a revolution led by a commercial middle class. In the early nineteenth century the Ottoman reformers attempted to unite all non-Muslim minority groups under the banner of 'Ottomanism' which provided a common Otoman citizenship for all. However. the national integration of the non-Muslim components of the Ottoman Empire was a failure in the sense that losses of territory during the nineteenth century and early twentieth century could not be prevented. The Young Turk constitutional regime of 1908 was a response to fe failure of Ottomanism with regard (n) the persistence of the minority problems of the Empire. The minority groups performing economic activities and services. but holding no power in the central government. 
constituted a threat to the central authority as they became more and more integrated into Westem capitalism.

Although this cconomic division of labour between the Muslim and non-Muslim elements of Ottoman society can be seen as the basis of ethnic conflicts between the TurkishMuslim and Christian groups it cannot be seen as the sole motive behind the ethnic tensions leading to the Turkish Revolution. The Christian minority groups were more threatening at the political level since they demanded political independence. In terms of attaining national integration the Muslim components of the population was as much a problem as that of the non-Muslim groups in the eyes of the Ottoman bureaucrats. The principal problem for the bureaucrats was the religious and ethnic problem that challenged ihe state's legitimacy.

During the Turkish Revolution there was no capitalist industry and no capitalist agriculture. Wage workers in services and manufacturing were very embryonic. In addition Turkish peasants and workers were not an integral part of the revolution. The local notables were the only influential partners in the governing coalition of Turkey. However. despite the growth of their influence and authority, these notables still had no autonomous status comparable to that of the European feudal nobility (Mardin 1973, p. 174). According to Ozbudun, the alliance between the new military-bureaucratic elite opposing the central Ottoman government and the landed local oligarchy claiming political participation should not be viewed as the inevitable outcome of their identical interests. but as a result of a deliberate and relatively free choice on the part of the former (1970, p. 388). 
The alliance between the military-bureaucratic elite and the landed local oligarchy was aiso encouraged by the circumstances of the Turkish War of Independence. Ozbudun argues that this war-time alliance was partly due to the Kemalist conception of modernization. Local nobility supported the Kemalist modernization program because the program involved the adoption of the Western political and cultural institutions with no radical change in the social structure. In his words, "the local nobility supported the modernization program of the national military-bureaucratic elite, in return for which it was allowed to retain its land, status, and local influence, as evidenced in the conspicuous absence of any real land reform under the Republican governments" (Ozbudun 1970. p. 389).

What follows i: an analysis in detail of the various forms of resistance movements that took place both during the Turkish War of Independence and during the formative years of the Turkish Republic. I do not confine my analysis to resistance movements only, but include those movements supporting the Nationalists as well as any 'reactionary' ones which were neither 'against' nor 'supportive' of the developments which took place in Turkey during the period under investigation. I include these supportive and reactionary movements since they, together with resistance movements, reflect the border between what can be classified as 'for' or 'against' state-building. In this respect some of the 'reactionary' and 'supportive' movements, which were not influential in the formation of the modern Turkish state, are presented merely as background information. It is important to note that a shift from these reactionary movements to more developed forms of resistance has been prevented by state practices. Thus, the discussion of these reactionary 
152

movements illuminates the power of the state over potential resisters during critical years in Turkey's history. Moreover, all these movements, whether resistance, supportive or reactionary, reflect those critical points of transition in relating cultural and pre-political forms of resistance to the process of state-formation. For example, the support Nationalists received from many bandit leaders was used against various sporadic peasant rebellions and this support became very influential in the formation of the Turkish state. The precise nature or importance of particular forms of resistance during critical years in Turkey's history, and which were and which were not the most significant forces shaping Turkish state-formation will be discussed in Chapter Five. 


\section{CHAPTER NOTES}

[1] There are debates about the original name of this secret organization. Sime argue that it was nanied as the 'Union of Ottomans'. However, it is known that Ahmet Riza, an influential leader of the Yirung Turk leader. persuaded the group to change their name to 'Committee of Union and Progress' befire 1895 (Mardin 1983, p. 29).

(2] Kabasakal, too, makes the same argument. He claims that these regional organizations rejected any role of political parties for they wanted to prove that they had no connection to the Ununists despite the fact that most of their members were Unionists (1991, p.79). Along similar lines, Frey argues that the Union and Progress, which was a national party organization, served as an implicit model and partial foundation for the later creation of the 'Defense of Rights' and 'People's Party' organizations (1965, p. 301).

[3] Oran claims that these societies of resistance were formed not against the Allied powers but against the Greek occupation. The possible establishment of an independent Armenia, for him. was the motive behind forming these organizations (1990, p. 112). On the other hand. Tuncay argues that some of the Societies of Defence formed in Thrace and Anatolia were controlled by the Ottoman army and government (1992, pp. 32-33).

[4] Turks did not have sumames until the Name Law of 1934. I cite the family names of those individuals who adopted surnames after 1934 in parenthesis. Mustafa Kemal. too, adopted 'Ataturk' as his surname and dropped the Arabic name 'Mustafa', becoming Kemal Ataturk after 1934.

[5] Aybars refers to ten major rebellions between the years 1919 and 1921 some of which had an ethnic origin (1988, p. 16). Circassians were involved in two of these revolts (Anzavur and Duzce Revolts). Some of them were Kurdish revolts, and one was organized by the Greeks of Turkish nationality. Mustafa Kemal Ataturt, in his speech delivered at the Grand National Assembly in 1927, refers to thinty four territories involved in internal rebellions which began during the year 1920 against the national struggle (Ataturk 1927, pp. 383-384). 
[6] These special Courts of Independence had summary powers of execution. In the first three years of its establishment approximately 1,500 people were executed. Out of this number 1.054 were hanged (Aybars 1988, pp. 167,168).

17] Transiation of the descriptions are as follows: ulema: the clergy: dervish (dervis): a member of any of various Muslim fratemities or orders taking vows of poverty and austerity: sheikh (seyh): the head of an Arab family, or of a clan, tribe, or village; pasha (pasa): a general (also a title, placed after a name, given to officers of high rank); bey: mister, efendi: gentlemen: aga: a title of respect. and the owner of the biggest piece of land in a village; hoca: Moslem religious clerk.

[8] There was also another group called the 'Muhafaz-i Mukaddesat Cemiyeti' (Society for the Preservation of the Sacred Traditions). It was formed by two clericals. who were members of the Assembly, in order to fight against communism and against the Society for the Defence of Rights (Berkes 1964, p. 449).

[9] I took the quotation from Berkes who translated from the original 1927 edition of the 'Speech'.

[10] Both. Tuncay and Oran (and Mumcu) refers to the military research conducted and published, in 1972. by the Turkish Chief of Stafi, named 'Revolts in the Turkish Republic 1924-1938' (Turkiye Cumhuriyeti'nde Ayaklanmalar 19241938).

[11] The 'Law for the Maintenance of Order', which remained effective until March 1929. gave extraordinary powers to the government. Also, with the suppression of the revolt, forty eight people were sentenced to death and hanged after being judged in the Eastem Court of Independence (Mumcu 1991, p. 156). Many Kurdish families - in the years of 1925, 1927 (400 families), 1935. 1960 - were forced to migrate to Western Anatolia by law (Mumcu 1991, p. 181, 238; Tuncay 1992. pp. 173-175).

[12] The 'Turkish Heart' organization was a politico-cultural organization formed by students at the military medical faculty in $\mathbf{1 9 1 2}$. Through this nationalist organization Turkism was merged with pan-Turkism (Berkes 1964, p. 346; Frey 1965. p. 38). 


\section{CHAPTER 4 FORMS OF RESISTANCE EXPERIENCED IN TURKEY}

\subsection{Introduction}

As pointed out in Chapter One, state-building and resistance are connected to one another in two different ways. The process of state-building can be analyzed at two separate but related levels with regard to the forms of resistance experienced during the process of making states. On the one hand, state-building provokes resistance. On the other hand. resistance shapes the nature and the form of the process of state-making and its outcome. In this chapter I examine various forms of resistance movements which enables one to focus on the structural connections in the process of state-formation such as the relationship between military and civilian development, and between central and local state. 
The forms of resistance provoked by the state not only reflect the power struggles among various groups in any phase of the state-making process but also the cultural relations between the state-makers and those resisting. My primary concem in this chapter is to analyze the forms of resistance provoked by the Turkish state and to discuss the reasons for popular discontent against state-builders.

The second part of the state-building process reflects the impact of resistance on statebuilding. In this context analyzing the responses of the state to resistance is crucial for understanding how resistance shapes the form of the state. I look at the impact of resistance on the form and nature of the state in Chapter Five. I assume that the silence about resistance in the Turkish literature has influenced the conceptualization of the Turkish state and its formation. In this context Chapter Five will explore some of the consequences of these silences in terms of conceptualizing state-formation (and state policies) in Turkey.

I now explore the forms of resistance experienced between the years 1919 and 1935. I first look at the period between 1919-1923, the Turkish War of Independence, which constitutes the first period of the state-formation process. The second period roughly covers the years between 1923 and carly 1930s. Although the new state was established in 1923 its authority remained significantly challenged until 1930s. In this respect, this second period also constitutes part of the state-formation process.

The form of the state-building process was not the same during the War of Independence and in its aftermath. As a result both periods provoked different forms of resistance which 
in turn shaped the nature and the form of the state in their own ways. The forms of resistance experienced after the establishment of the Turkish state were the products of a different dynamic compared to the first period. During the first period. protest was much more unorganized and scattered. Also the borders between resistance and revolt were not clear during this period. Social banditry, military desertion, various other forms of individual resistance acts, and sporadic rebellions were the dominating forms of resistance. These forms of resistance had no clear programme.

After the Republic was proclaimed in 1923 more organized forms of resistance developed within Anatolia which were basically religious and ethnic in character. Although some of the previous rebellions, too, were religious and ethnic in character, the opposition movements following the establishment of the state often resulted in revolts which had a different dynamic than the former. The main motive behind these revolts which became the dominant form of resistance after the establishment of the Turkish state was to preserve the Islamic and ethnic (mostly Kurdish) identity. However, these revolts and protests were local and regional, and ethnicity and religion did not serve to unify these protests to initiate a revolutionary peasant movement. There were other forms of resistance and protest during this period against the reforms made by the state. These include resistance to the hat law, and the unveiling of women, and protest against the usage of the latin alphabet.

Resistance and revolt in Turkey were not directed against landlords or local religious leaders as was the case in Europe. Since the Ottoman times, local power holders and the peasants have revolted together against the central authorities. In other words, resistance 
was very closely linked to the struggle against state authority. The situation was not much different during the War of Independence. In the early days of state-building those involved in protest were not simply struggling against the Ankara government in favour of the Istanbul government, but against 'state authority' to protect their own traditional ways of life. After the establishment of the Turkish Republic, when the state became involved in a transformative process, the nature of the struggle between state-makers and the resisters changed. Issues such as a republican form of government or a secular Turkish state, became sources to widen the conflicts which in turn had a deeper impact on the form of the new state. In this respect the analysis of the Turkish state-formation process requires a detailed study of resistance and opposition, both at the local and national level, against the state-makers.

Although there were no well developed forms of formal opposition to the state in Turkey, there were various movements of resistance which I discuss in this chapter. These include social banditry and military desertion, non-Muslim opposition. opposition in Istanbul. religious resistance, ethnic resistance. and incidental acts of resistance against the reforms carried out by the state. These movements of resistance varied from one place to another and also took different forms over time. It was the regional and the local component that provided the grounds for different forms of resistance in different regions. The forms of resistance and opposition experienced in Turkey lacked organization and they were less developed compared to the ones experienced in West European countries. They had no visible consequences. As I discussed in Chapter Two, section II.4.3, resistance to state was almost always pre-capitalist in form. and the local revolts never reflected a unified 
peasant dissatisfaction to the building of the Turkish state. In addition there were no well organized revolutionary labour movements.

I do not exclude from my analysis those movements which were supportive of the efforts to build a new Turkish state. There were certain groups and communities supporting the Nationalists both during and after the War of Independence. For example while there were many Kurdish tribes revolting against the Ankara government, there were also a considerable number of other Kurdish tribes cooperating with the Nationalists either by providing the needed armed forces or simply by not being involved in any kind of opposition against the Nationalists.

To conceive of resistance movements as part of the state-building process, it is necessary to understand the nature of the opposition that dominant groups faced in their struggle for the establishment of the new Turkish state. This is an essential dimension for grasping the dynamics of the period from 1919 to mid-1930s. Also the focus on resistance is useful in understanding the ways in which resistance was channelled or directed by the dominant groups.

Resistance to state formation cannot be separated from the beliefs, values, common-sense, and attitudes of those resisting the state. In other words, there is always a type of confrontation between the state makers and various groups belonging to a specific culture other than the powerful or dominant one. Consequently, focusing on the forms of resistance with a cultural perspective will provide the grounds for exploring how large sections of the population related themselves to the new Turkish state. In this context I 
selectively analyze certain aspects of popular culture to which the resisters belong. For it is within the popular culture that one may find the intentions behind the actions of cerain groups or communities.

\subsection{Realstance and the Struggle For National Independence (1919-1923)}

Before embarking a discussion of the forms of resistance experienced in Turkey during the War of Independence I outline the conditions under which the Turks carried out their struggle for the establishment of the new state.

The Turks were fighting against internal opposition and revolt as well as against the Allied Powers who occupied parts of Anatolia after World War I came to an end in 1918. After the signing of the Moudros Treaty the Allied troops occupied Istanbul (formerly Constantinople).[1] Many Turkish officials and officers were arrested by the Allies and accused of participation in massacres and bad treatment of prisoners-of-war. Those arrested were all imprisoned in a camp on Malta. During the first months of 1919 other parts of Anatolia were occupied by the Allied Powers. The Italians landed their troops in Antalya (Adalia), the Greek in Izmir (Smyma), the British in Samsun area, and the French in Cilicia. In addition to these the Armenians in the Caucasus constituted another front. During the Independence War the Greek population in north-central Anatolia constantly struggled to establish a Greek state (Pontus) in the region. In the meantime the Kurds, too. fought for an independent state in the Eastern provinces of Anatolia.

The Treaty of Sevres which was signed in August, 1920 had a considerable impact on the shape of Turkish struggle for independence. It was based on the secret treaties between 
the Allies. Italy and Greece, before they entered the war with the Allies. were promised sections of Anatolia for supporting the Allies. France and England also had their interests and they were all fitted into the Treaty of Sevres. As Armstrong notes. annexation of territory was concealed behind the American idea of 'mandates' (1925, p. 117). Based on this treaty Syria and Cilicia were allocated to France: Izmir (Smyma) and Western Thrace. and most of Eastem Thrace to Greece: Antalya (Adalia) to Italy. Russia nad been promised Istanbul (formerly Constantinople) and the area of the Straits and the Bosphorus. However, since Russia had its own internal problems she did not pursue an active policy and the lands promised to her were put under an international regime. The Sevres Treaty was based on a Peace Conference which took place in 1919 in Paris, and at this conference, not only Britain. France and Italy, but also Greek. Armenian. Zionist. Arab and Kurdish representatives pressed their territorial claims. The Treaty of Sevres (1920) that resulted from this conference provided for an Armenian state to be formed out of the vilayets of Trabzon. Erzurum, Van and Bitlis, and explicitly left room for the establishment of an independent Kurdistan (van Bruinessen 1992, p. 272).

Before the signing of the Sevres Treaty, the French had made an armistice with the Nationalists in May, 1920 after they were forced to evacuate Maras in the southeastem front. This was a recognition of the Ankara government by the French which marked the beginning of some conflict among the Allies with respect to their foreign policies. In late 1920 and early 1921 treaties were signed with Armenians and Russians. Later the Soviet government supported the Nationalists by sending gold and munitions to them. During the years 1921 and 1922 the Turks continued to fight with the Greeks in the westem front. 
The war with the Greeks ended in September 1922, when the Greeks were forced to withdraw from Anatolia. After the war with the Greeks ended the Treaty of Lausanne was signed between the Allies and the Turks in July 1923. This treaty recognised the new Turkish state. I deal with these developments in the following pages.

\subsubsection{The Nattonal Forces}

Here I tum to a discussion of the National Forces (Kuvayi Milliye) which were the armed guerilla forces who carried the burden of the War of Independence until the establishment of the conventional army in 1921 . The term National Forces is sometimes used to refer to the period of National Struggle as a whole. including not only the armed militia forces but all the 'Societies for the Defence of Rights', National Congresses, the Assembly in Ankara. and those in favour of the Nationalists. However, it specifically refers to the rural militia forces established in Anatolia after the Greeks occupied Izmir on May 15, 1919 (Selek 1963, p. 96). Bandits and military deserters were also part of the National Forces.

It is generally argued that the physical depletion of the peasantry caused by continuous wars since 1911, and the distrust towards the military officers which developed over the years had an impact on the formation of these armed militia bands. The Ottoman government did not declare war against Greek occupation. and this too, contributed to the formation of the militia bands. Consequently the newly formed militia forces, which were perceived as separate from the official Ottoman army. received much respect and support from the local communities. Provincial notables financially supported the National Forces (Muderrisoglu 1974, p. 187: Avcioglu 1986, p. 988). Many military officers, too, 
believed that it was possible to win the war relying only on the militia forces. The Ottoman government was the main opponent of the National Forces which tried to crush these forces on every occasion. Nevertheless the National Forces were not representative of a unified peasant movement.[5]

The National Forces were composed of heterogeneous groups. These were as follow': (1) the bandits called 'eskiya' and 'zeybek' living in mountains. (2) military deserters (including those who deserted before or during War of National Liberation. and those who joined the National Forces refusing a future calls to arms). (3) criminals and outlaws. (4) prisoners freed from prisons. (5) adventurous persons involved in robbery and similar activities. (6) those who formerly participated in counterrevolutionary movements and later joined the National Forces in return for pardon, (7) those who were collected from villages and small towns in similar ways to otficial calls to arms. $(8)$ and the volunteers who joined the National Forces (Selek 1963, pp. 98-99). The National Forces had different names in diffe:-nt places. Each of these forces had special names, taking either the name of the commanders or the leaders heading them. or the name of the place where they were first formed (Selek 1963, p. 99).

The National Forces were headed by various people with different backgrounds. The leaders can be grouped into four: (1) bandit leaders (the 'Efe' or 'eskiya'). (2) those who fought in the Balkans against the revolutionary plotters (especially Bulgarian, Greek, and Serbian) known as the 'comitadji'. (3) civilian leaders some of which were the provincial notables, and finally (4) military officers of the former Ottoman army who joined the Nationalists (Selek 1963. pp. 100-101). A large section of the National Forces has also 
been known as 'Kuvayi Seyyare', which means the 'Mobile Forces'. so as to refer to the forces headed by guerilla leaders or bandits. Mostly the forces headed by Cerkes Ethem (a circassian guerilla leader) are referred to as the 'Kuvayi Seyyare' which in fact was part of the National Forc^s. I refer to the militia band headed by Cerkes Ethem in sections IV.2.2 and IV.2.5 of this chapter.

Following Ergil, these rural guerilla forces can be re-grouped into two bro ad categories, namely the 'militia bands' and the 'brigand bands', which were both part of the National Forces. They were the only armed groups that the Nationalists could rely on until the establishment of the conventional army in 19?1. Militia bands were the ones composed of peasants who were gathered, equipped, and led by local notables. Brigand bands, on the other hand, again composed of peasants, were led by the peasants themselves. However. their leaders were outlaws and criminals. They supported the Nationalist Forces during the critical years of the National Liberation Struggle (Ergil 1974, p. 86). In general, militia bands or guerilla bands were never well organized and coordinated, and lacked political consciousness. Each individual band acted in its own initiative, and it was not easy for the National govermment to organize these bands into regular forces.

As Steinhaus argues, most guerilla bands reverted to practising banditry whenever possible and they did not hesitate to cause trouble for the Nationalists (1974, p. 99). The only leaders that these bands respected were the guerilla leaders who, in general, were in conflict with central authority. According to Toynbee, a British historian,

the maintenance of the front had to be left to chettes [bands], who in many cases were professional brigands and went on making their customary livelihood in the 
areas which they were 'defending.' Their depredations, being economic. took little account of nationality, and there are authentic cases of Turkish villages which, in this first phase of the struggle. actually called in the Greeks in order to be rescued from their national 'protectors.' The Angora [Ankara] Government did not yet dare to interfere. for the object of its existence was to carry on the war. and it had nothing so far but this screen of chettes to oppose to the enemy (1923, p. 156).

In certain respects it can be argued that guerilla leaders allied with the Nationalists only temporarily when faced with foreign invasion. For example. with the ending of the War of Independence. most bandit leaders turned against the Nationalists and the newly established regular army to save their powerful positions they had held for a long time. As Ergil puts it, “although there were armed militia groups composed of peasants among the Nationalist guerilla forces, at a time when these rural militia bands were the only military pou :r, they lacked the political consciousness and organization necessary to defend peasant rights" (1974, pp. 85-86).

\subsubsection{Military Desertion and Social Banditry}

In this section 1 discuss military desertion and social banditry in Ottoman Turkey during the War of Independence. Both the bandits and the military deserters were largely part of the peasantry and their confrontation with the state constitutes an area revealing the ways through which power was exercised within the Turkish society in this time period. For without taking into consideration the resistance side of any domination relation, power struggles (their location and the methods used) cannot be grasped truly.

A focus on social banditry and military desertion as major forms of resistance $\lll$ statebuilding cannot be separated from the cultural conflicts of the period represeniing the constant struggle between the national authorities and alternative power groups as part of 
the peasantry influenced by the discourses of popular culture. Social banditry and military desertion reveal the conflicts other than the ones which took place within the dominant classes. While social banditry resided outside the limits of the institurions, military desertion was a form of resistance within the institution of the army. Nevertheless both forms of resistance were expressions of peasant dissatisfaction. In addition physical attacks on military officers who represented the state was another form of resistance which was inherited from the Ottoman times and continued as a practice against statemakers in the formative years of the Turkish state.

The peasants preferred to form guerilla bands rather than performing military services. For brigandage provided more personal and immediate gains than serving in the army. Military desertion has been a serious problem for the central authorities since the Ottoman times. Prolonged wars has been one reason for massive withdrawal from the army (Avcioglu 1986. pp. 913-914). Another reason for deserting from the army was the lack of central organization capable of providing order in Anatolia (Aybars 1988, p. 7). In Yalman's words,

extremely severe punishments were tried, but with effects just the opposite to what was sought. In self-defense deserters were more energetic and took concerted action against the Government's power. The absence of public safety became more and more a direct menace to the Government itself. It was like an embryonic revolution. In many areas real authority rested with the outlaws. There were no forces available for use against them... The only possible measure was a general amnesty for all offenses in any way connected with desertion; and it was proclaimed on July 20, 1918. In addition, proclamation after proclamation was issued to induce deserters to return to the front (1930, pp. 263-264).

Another reason for military desertion was due to the fact that recruitment to the army was made by the Ankara government which was still illegal in the eyes of many. The abolition 
of military service by the Sultan further contributed to this situation. Military desertion remained a serious problem until the end of the War of Independence.[2] In addition. because the Ottoman government did not declare war against Greek occupation many people preferred to remain uninvolved in a new war against the occupiers. However, as Yalman notes, this was not the only motivation for military desertion. Deserters could not go back tc their villages because they were outlaws. They feared capital punishment. and since they had kept their rifles and ammunition they took refuge in the mountuins. They formed bands of various sizes; soine as many as one hundred and fifty. These bands often robbed trains and attacked villages, sometimes even towns. Particularly in the Bursa area. strong bands were entirely masters of the situation. In Yalman's words.

They divided the territory into zones of influence and ruled over the peasant population. Collective safety could be bought from them for definite sums. The peasant population had no choice but to pay. The Government was not strong enough to protect them, though at the beginning of the War it had been able totally to disarm them. No means of self-defense existed (1930. p. 262).[3]

Before and during the War of Independence social tanditry and military desertion threatened public safety. Aybars records that there were 300,000 military deserters in 1918 (Aybars 1988, p. 21). In Sivas only, a central Anatolian city, there were more than 500 robbers, and in Sansun, a city in the Black Sea coast of Anatolia, many Turks formed guerilla bands as a means of protecting themselves from the bands formed by the Greeks of Turkey (known as Rum) (Aybars 1988, p. 7). This was the area where General Mustafa Kemal was sent, in 1919, by the Sultan to maintain order and to protect the Greeks of Turkey from attacks by the Turks (Eroglu 1990, pp. 109-110).[4] In general, robbery was the most important thing which threatened public safety during the War of Independence. 
It also undermined the authority of the newly established National Assembly.[5] It was mostly the military deserters who were engaged in robbery, kidnapping, attacks on civilians. and murder throughout Anatolia. The Courts of Independence, established primarily to prevent military desertion, executed all those involved in robbery. kidnapping, and murder. However, the people helped those involved in such crimes to hide and this constituted one of the biggest problems in arresting them. Those helping the cutlaws were also convicted by the courts (Aybars 1988, p. 72). Massive withdrawal from the army, as Scott argues, may have radical implications for the army as one of the central institutions of the state, and this was the case in Turkey (Scott 1985, p. 32).

What follows is a discussion of social bandity in various parts of Anatolia and Thrace. and some of those well known bands and their leaders that first supported the Nationalist Forces and later rebelled against the Ankara government. I also refer to some of the scattered bandit bands which were engaged in traditional banditry and who threatened public safety throughout Anatolia during the War of Independence. I elaborate on the reasons for forming such bands and the common values they held as resisters to state authority.

According to Hobsbawm. when banditry merges into larger movements, it becomes part of a force which can and does change society. Social bandits do not easily come to terms with modern revolutionary movements. However, social bandits can easily become part of larger movements when it is the case of national independence movements, since their aspirations can be expressed in terms comprehensible to archaic politics. Accordingly, primitive movements of tribal or national resistance to conquest may develop the 
characteristic interplay of bandit-guerillas and populist or millennial sectarianism (Hobsbawm 1969. p. 88). This was the case in Turkey during the War of Independence where the social bandits became part of the National Forces who were fighting against foreign conquest. In view of this perspective, I focus on types of social banditry and argue that the Turkish experience fits the Hobsbawm model.

The bandits in Anatolia were known as the 'efe' and the 'eskiya'. The 'efes' were the bandits of the Aegean region of Anatolia.[6] Yet use of the term 'efe' was not restricted (o) this region only. As Noyan claims there were 'efes' in Ankara, Balikesir. and Kastamonu as well (1982, p. 11). 'Zeybek' was the name given to those who formed the bandit bands under the leadership of the 'efe'. During the Ottoman rule the 'efes' often rebelled against the Ottoman state; they resided in mountains, as did the 'eskiya'. The 'eskiya', on the other hand. was a term often used to refer to the bandits in the Eastern regions of Anatolia. According to Selek, although there were some differences between the 'efes' and the 'eskiyas', the two forms of banditry were similar (1963, p. 100). Bayrak. too, supports this view. According to him, it is important to distinguish between 'social' bandits and 'ordinary' bandits rather than looking at banditry on a regional basis. For it is not the regional factor that distinguishes one form of banditry from another, but it is the form and nature of banditry that counts for analyzing various forms of it (Bayrak 1985, p. 66). In general, there were many 'honest' bandits as well as those with a bad reputation.

Bozdemir claims that, 'zeybek' and 'efe' banditry may be the outcome of a military organization which existed in the past which never became institutionalizeci over time. To him banditry was a way for gaining respect among the local populations by challenging 
the central authority and sometimes temporally acting as if they represented the local authority. They often became the heroes of legends. In times of crisis they negotiated with the central government and in return for a pardon they attained a privileged position. They could keep their rifles and retain their personal and public rights. The Kemalists (Nationalists)managed to integrate many such leaders into the National Forces. After the War of Independence this form of banditry vanished altogether (Bozdemir 1982, p. 85).

Ozturk's study on banditry in the eighteenth century in Antakya. a city in South Eastern Anatolia, is worth mentioning.[7] He classifies the bandits into four groups considering the social causes of banditry. These are as follows: (1) banditry caused by the Levents. (2) tribal banditry. (3) prolonged conflicts between families which forced the family members to choose banditry as a means to end these conflicts, and lastly (4) individual banditry.

The Levents (also known as Sarica or Sekban) were those who lost their connections to the land due to the deterioration of the 'timar' system. The Levents were employed by the local authorities for two reasons. First the local authorities had to provide the manpower needed in wars, and second they had to secure their own safety. Being a Levent was an officially recognized position. The local nobility and the officers, too, hired the Levents as guardians to protect the status of those who feared to lose their positions.[8] During times of peace, because the Levents were detached from agricultural activity, they began to be involved in brigandage. Despite the efforts to abolish them they increasingly continued to threaten public safety (Ozturk 1990, pp. 968-969; Ulucay 1944, p. 131). 
Tribal banditry was the result of the conflicts between the Ottoman government and the tribes. The tribes were nomadic communities and they refused to settle on the land. to pay taxes. and to be controlled by the government. The tribal bandits were supported and protected by the whole tribe. In addition, the tribe as a whole fought against the central authorities in order to protect their members. Thus tribal banditry remained an influential form of opposition to the Ottoman government (Ozturk 1990. p. 972). From time to time the tribal bandits actually fought with the government forces, and revolted against the Ottoman state.[9] As Ozturk claims, this form of banditry did not stem from economic reasons only since most of the tribes were able to pay their taxes $(1990$, p. 985$)$.

Another form of banditry stemmed from the prolonged hostilities between 'extended families', which was a characteristic family type in the past. When members of these families were involved in ordinary crimes it often resulted in family feuds. The local administrations were not strong enough to resolve these conflicts. Families sometimes turned to banditry to protect themselves. However, family feuds formed the ground for banditry to be exercised more widely among the tribes. Gates, who worked as a Christian missionary in Eastern Anatolia for many years from 1880 onwards, writes about an incident he witnessed in 1883 . In his words, "in a village on our route the people were fighting over a woman who had been abducted. Half of the villagers were shooting at the other half, but they obligingly held their fire, signalling us to pass between them. It was a village feud, and strangers should have no part in it" (1940, p. 62).

According to Gates's observations there was one general cause that gave rise to family feuds in 1880 s. Formerly the tribes were kept in order by chieftains called 'beys'. These 
s:hicftains handled all tribal matters and provided justice among large families. Over time sme of these chieftains became very powerful and resisted government's attempts to collect taxes. The Ottoman sultans weakened the power of the chieftains and destroyed them which gave the opportunity for less important persons to gain power. As a result the tribes became more and more divided into clans, and each became involved in some kind of a dispute which often ended in blood revenge. These endless family feuds mostly became the basis of social banditry (Gates 1940, pp. 83-84).

In addition. most of the families continued to be involved in banditry because it provided more gains to them in supporting their families. They often plundered the properties of the officers, civilians, and merchants and sometimes murdered them (Ozturk 1990, pp. 978-979).[10]

Lastly there were individual bandits who were basically peasant outlaws and they, too, threatened public safety. This type of social banditry was caused by the weakening of state authority which was linked to the deterioration of the state structure (Ulucay 1944, p. 140). These classical bandits were either from the military class like the Janissaries or from among the artisanal class. Some of them were just ordinary peasants with no employment. The bandits had no clear aims in their protest and they mostly were involved in plunder and murder. They did not strike the forces of the government unless necessary. Instead they struck at communities with no self-defense or at travellers (Ozturk 1950. pp. 980-981). 
The traditional social bandits in Anatolia were the outcome of the Ottoman soxial organization. Moreover, in the Ottoman society military service was a life-long duty for the peasants. The peasants were also expected to pay heavy taxes. and sometimes these taxes were collected very randumly. In general. the peasants were continuously subject to oppression by military officers who were responsible for maintaining the existing social order. As a result, the economically insecure peasants had no choice but to reside in mountains and form semi-political bandit bands (Steinhaus 1974, p. 96). This form of banditry is similar to Robin Hond type of banditry as discussed by Hobsbawm since they fought for justice and social equality as Robin Hoods did (Hobsbawm 1969. pp. 34-35).

Gates writes that. "living conditions in eastem Asiatic Turkey may be judged from what 1 found in northern Mesopotamia. The government was feared as much as the bandits that roamed the plains, for to the people it meant the agency for the collection of taxes with cruel beatings and the merciless power that conscripted men for military service. Soldiers sent to Arabia were considered as doomed to die from poor food and disease... The bandits everywhere made it necessary to travel in caravans or to secure a government escort" (1940, pp. 25-26).

According to Bayrak. social banditry had evolved through three stages since the Ottoman times. During the Ottoman rule the peasants had become bandits and resisted central authority in response to heavy taxes and government oppression. During World War I, many began to choose banditry as they deserted from the army. Prolonged wars contributed to military desertion which gave rise to a new group of bandits living in the hills. During the War of Independence banditry further evolved into a new stage. Social 
banditry began to represent a form of anti-feudal and anti-imperialist movement, and those up in the mountains had joined the war against the invaders. Still a fourth stage followed. After the War of Independence, in some areas where feudal relations were prevalent, individual social banditry continued to exist (Bayrak 1985. p. 28).

Although Bayrak classifies banditry into these stages it can be argued that the first three forms of banditry continued to exist simultaneously during the War of Independence. In addition, to characterize all forms of social banditry as an anti-imperialist movement during the War of Independence is an overgeneralization which can obstruct the reality. Splits between the Nationalist and 'anti-nationalist' applied not only to bandits but almost to all social groups, such as the Kurdish tribes, religious leaders, local nobility, and simply the local population. In effect, following Hobsbawm's model, social banditry did merge with the Turkish Independence Movement to a considerable extent.

Another form of social banditry existed in the Balkan regions of the Ottoman Empire which havi a different nature than the ones discussed above. Although this form of social bandity is not directly related to the Turkish War of Independence it is worth discussing. For it refieis the nature of conflicts experienced among the peasants in the Western territories of the Ottoman Empire. In addition, assuming that this form of banditry had some influence over the lives of a wider peasant population, it is necessary to look at some of the characteristic aspects of Balkan banditry. Haiduk type of banditry better characterizes the form of peasant resistance in Ottoman society than Robin Hood type of banditry since it is defined in political terms, and it reflects a more permanent and established challenge to official authority than the Robin Hoods. However, Robin Hood 
type of banditry, which is characterized by close ties between the Robin Hoods and the peasants (Hobsbawm 1969. pp. 34-35), was also widely practiced in Ottoman society.

These bandits in the Balkans were called 'haiduks'. They represented a collective and organized form of peasant resistance to official authority and oppression. It is argued that haiduk banditry was a form of peasant resistance not only against the Christian landlords but also against the Ottoman conquerors (to liberate their land from Ottoman dominition). In South-Eastern Europe, first spontaneously and later in organized forms. groups of armed men emerged among those expelled from their lands or escaping from serfulom (Hobsbawm 1969, p. 60).

Stojanovic, in his work on Balkan banditry, argues that Turkish rule in South-East Europe had created particular relations between the conquered and the conquerors which were expressed in the institutions of haiduks and (Greek) kelphts.[11]

The phenomenon of going to haiduks in almost all Balkan countries and during the entire period of Turkish rule had various causes, so that the relevant gouls too were not always identical...Its roots are predominantly of an economic nature and it is a result of the resistance by the conquered people against social oppression. primitive system of power and the Turkish violence in general. Haiduks and klephts where in their essential substance elemental popular movements, a kind of protest of the peasant masses against political oppression, dificult economic position, violence and exploitation (Stojanovic 1984, p. 223).

As Stojanovic notes, this form of social banditry can be traced in the literature which dates back to the fifteenth century. The haiduks were ideal fighters who became national heroes. As Hobsbawm argues, the definition of haiduk-hero is political, and in the Balkans he was a national bandit who defended the Christians against Turks. In addition their motives for going into the mountains were mainly economic (1969, p. 64). 
Haiduks and klephts lived in mountains and forests. They attacked Ottoman caravans and merchants, and caught and brackmailed prominent individuals. In addition to these. haiduk and klepht squads endeavoured also to gain as much plunder and slaves as possible. Both haiduks and their families lived off such plunder (Stojanovic 1984, p. 232).

In Hobsbawm's view, as pointed out above, haiduk banditry was a more serious. permanent, and institutionalized challenge to official authority than the Robin Hoods and other robber rebels which emerged from any normal peasant society. Hobsbawm, too. argues that Balkan haiduks fought against Turkish domination. However, he also notes that there is no evidence that Balkan haiduks set out to liberate their land from the Turkish yoke, or would have been capable of doing so $(1969$, p. 70$)$. Large numbers of peasants became bandits at the beginning of the Balkan Wars of the 1870's. Hobsbawm, referring to the detachment of Bosnia and Hercegovina from the Ottoman Empire, argues that these movements which iniizated the Balkan Wars reflected a characteristic combination of mass mobilization and expanded bandit activity. In addition, in Hobsbawm's view, where there is a strong haiduk tradition banditry may impose an even more distinct pattern on such revolts (1969. pp. 85-86).

According to Steinhaus, the guerilla bands formed in Anatolia can be grouped into three types with regard to the causes giving rise to their formation. First, he refers to the occupation of certain parts of Anatolia by non-Muslims who oppressed the Muslims which initiated resistance among the local populations who formed guerilla bands to protect themselves. The Kurds, who had a strong tribal organization, played an important 
role in this context. I discuss this first group in the following pages when looking at the conflicts between the non-Muslims and the Muslims. Secondly. he refers to the military officers and urban civilians who formed national resistance groups which were basically political organizations against foreign occupation. The third group. as already mentioned. were the arned traditional Anatolian bandits (eskiya) who assumed a new role during the War of Independence.

With regard to this third group I find Toynbee's point useful. He argues that these new brigand bands were a recent institution.

There had always been 'economic' brigands in Anatolia - a straightforward profession. in which people of all local denominations and nationalities had engaged. They were the enemies of constituted authority, which had done its ineffective best to put them down. But these new 'political' chettes. though th. $y$ were partly recruited from the professiona' . and though their personal incentive was still loot, were in quite other relations with the civil and military authorities of their respective nations. So far from discouraging them, the authorities armed them, organised them. and gave them a free hand to accomplish results which they desired to see accomplished but preferred not to obtain openly for themselves (Toynbee i 923. pp. 278-279).

The Ottoman Empire had been involved in continuous wars since 1911. This situation significantly increased the number of bandits throughout Anatolia.[12] Armstrong, in his memoirs, describes the psychology of the Turkish peasants in the years 1915-1916 which explains the conditions that gave rise to high number of militury deserters most of whom became bandits.[13]

The villages through which we passed were empty of young men, and where there were Christians they were disloyal and, if the chance occurred, whispered treason to me. There was a sense of deadness. They were simple, sturdy folk, these Turicish peasants. They made no pretence of wishing to fight in this war. ! saw none of the wild enthusiasm of other countries, except among the recrusts we met 
singing along the roads. but they ware young and excited. For the rest. the country and the people were tired of the everlasting wars. and ever and again they cursed Enver Pasha and his German crew (Armstrong 1925. p. 34).[14]

I now refer to some well known bandit leaders who formed very powerful bands that carricd the burden of the $u$ ar until the formation of the regular Turkish army. The bandit bands and militia bands that were formed during the War of Independence basically were used against the counter-revolutionaries and against non-Muslim minorities such as the Armenians and Greeks of Turkey (Rum). The ie bandit bands also initiated the first resistance movements against the Greek invasion of Western Anatolia. Although there were hundreds of bands formed during the War of Independence. I refer only to six well known bandit bands that cooperated with the Nationalists. The activities of these bands reflects the general facts about their social composition and the reasons for choosing to back the Nationalists against foreign occupation and internal rebellions. I will also discuss the more traditional form of social banditry in the following pages.

Cerkes (Circassian) Ethem was one of the most important militia leaders during the Independence War. He became the leader of the irregular nationalist forces immediately after the Greek landing at Izmir.[15] His armed group was very strong and included . great number of regular officers and men. After suppressing the local revolts Ethem's band plundered and looted the people in the area as a reward for their success. In this sense his band was no different from other bands hezided by bandit leaders. Ethem is known as the leader of the 'mobile forces' for he moved from one area to another to suppress the revolts against the Nationalsts. 
Demirci Mehmet Efe was a well known bandit leader in Western Anatolia. Hiẹ ilmaz notes that Demirci Mehmet Efe had never engaged in ordınary types of bandit activities. such as robbing innocent people. He. on the other hand. is known for hanging many people during the War of Independence (1993.p. 171). With a large band of 'zeybeks' uncer his command he fought both against the Greeks of Turkey in Western Anatolia and against those involved in domestic rebellions.

Yahya Kaptan ended up in the mountains after he had murdered a Bulgarian that had killed his brother. He came to Istanbul in 1913 and joined the Unionists. During the War of Independence his band became the most powerful one in the Gebze area. He was arrested and killed as a result of some conspiracy initiated by former Unionists (Birinci 1971.p. 55).

Topal Osman Aga was the leader of a very powerful band that was formed in Northem Anatolia. Originally his band was involved in social banditry. After the Ottomans were defeated in World War I, he started to fight against the Greek bands formed in the Black Sea Coast of Anatolia.[16]

Ipsiz Recep was formerly a pirate on the Black Sea Coast. After the Allies invaded Anatolia. Ipsiz Recep released the prisoners from the prisons along the coast. formed his band, and joined the National Forces (Birinci 1971,p. 56). His wife, too, joined the band. Ipsiz Recep's band helped the Nationalists to collect arms and munitions. They also attacked French and Greek ships. In addition, he often struggled with the Circassians and Abazas (one of the ethnic minority groups of the Ottoman society), who were turned 
against the band of Ipsiz Recep by the efforts of the Ottoman government. He also fought against the Greeks on the Westem front (Hicyilmaz 1993, pp. 199-204).

Yoruk Ali Efe deserted from the army during World War I and formed his bandit band which became a very powerful militia force in 1919. As Hicyilmaz claims, he became an 'efe' after being whipped by a foreign officer in Izmir (1993, p. 181). He was known as an 'honest' man, as was Demirci Mehmet Efe. As Hicyilmaz puts it, he was not a bandit but the 'father' of the poor. He fought also against the bandits of the hills and against bands headed by minority leaders (1993, p. 181. 183). As a leader of a powerful 'zeybek' band he fought against the Greek invasion in Western Anatolia, and he initiated much resistance among other Efe's who ended up joining the National Forces.

In addition to these very famous bandit bands there were numerous other individual bands formed by military deserters and bandits throughout Anatolia (Atay 1958, pp. 111-112\%. Adivar. in her memoirs. refers to the bandits in Western Anatolia at the beginning of the War of Independence. In her words,

There have always existed on the mountains of Smyma semi-political bands that had achieved great local fame - like the companies of Robin Hood. They were in eternal conflict with the Ottoman government. They lived by kidnapping the children of the rich and holding them for ransom, robbing the rich merchants and killing the government officials and gendarmes; but they were sympathetic to the poorer peasants. Legends and songs of romance have gathered around them. In the early days of the Greek invasion, not having seen the manner of the occupation, they had come down from the mountains and had joined the Greeks. This was partly due to a desire to loot, and partly to their hatred of the Ottoman government. But before a month had passed, they had taken their arms and marched back again. Keukje Effe [Gokce Efe] was one of the first to lead his band against the Greeks. His story has turned into a sont of legend (1928, p. 61). 
Here I will continue to discuss the types of activities that these bands were involved in. including both the ones that joined the National Forces and the ones that continued (t) exercise traditional forms of social banditry. I also refer to Christian bands formed throughout Anatolia. I intend to demonstrate the motivations behind their actions in order to provide a better understanding of their formation and existence.

Adivar writes about the bandit bands formed near Istanbul in early 1920 . She refers to the one named the 'Twenty' which was a band formed by the Christians of Bakkal Koy who were cooperating with the Allies. There were also other bands of the same sort, one of fifty from Pasha Koy which worked over a bigger area, and another of eighty from Izmit which patrolled the inside of the peninsula. These Christian bands hunted and killed the Turkish villagers and refugees on the fields. The Turks smuggled arms and ammunition into Anatolia and the British and the armed Christian bands took action against such efforts. The Turks, too, had two bands farther inland. One was the band of Aslan Kaptan (Captain) who had a force of twelve, and the other was the band of Dayi Mesut (Uncle Massoud) (Adivar 1928, pp. 98-99). Aslan Kaptan struggled with the Christian bands to protect the Turkish peasants and the Nationalists. At one point in early 1920 he himself and Dayi Mesut guarded Adivar and some other Nationalists on their way to the new headquarters of the National Forises at Ankara. As Adivar notes most of the routes were held by the English cavalry and they needed protection not to be caught by the Allied Forces.

I find Adivar's comment on Sergeant Mehmet and a group of gendarmes - who escorted and protected Adivar during her escape from Istanbul to Anatolia - useful. In her words, 
"though it was obvious that Mehemmed Chavoush and the gendarmes did not get on together, yet they were in perfect agreement politically, in spite of the fact that he was an Anatolian and they were from Macedonia. Both hated the old government. Both thought it was too complicated and too exacting. They wanted to do away with the tax-gatherers and the gendarmes and substitute some sort of a national force to police the land and to fight against its enemies" (Adivar 1928, p. 100).

Armstrong, in his memoirs, refers to the problems caused by bandits. As he describes. -the hills were full of brigands and criminals and the villages lay depopulated and many burnt, and, even from within the towns, the brigands carried off the merchants and held them to ransom. Between the Christians and the Moslems was a great gulf of murder and incendiarism and rape and bloodshed" (Armstrong 1925, p. 155). As a British officer, Armstrong was involved in brigand hunting in Izmit Peninsula which was an area supervised by British Officers. As he tells the story. "For the minute the brigands reigned. They had little fear of capture by the British cavalry which had been sent to replace the Greeks until we were ready. They even became hilarious at the attempts of the men on great English horses or in heavy crashing boots, who pursued them through the woods, as they slid silently forward on their skin shoes... They would arrange with the intiligence agents and come and talk and drink with their innocent pursuers, who without knowledge of the language. customs or the land were as men blind. And so they had grown overconfident and insolent" (Armstrong 1925, pp. 156-157).

As Armstrong tells, each week they got news of robberies, murder, village raids, and men held to ransom. After they heard the news about a raid on a Jewish settlement village. 
they decided to declare war on the brigands. It was a renowned band of Greeks who had made the raid. The village where these brigands lived was Bakkal Koy. which was a village of Ottoman Greeks and it was raided shortly before the Jewish village wass attacked. The villagers in Bakkal Koy refused to give any information about those involved in the attack arguing that. "you come for a day and are gone. The Government changes often; but the brigands are always with us" (1925. p. 162). Armstrong writes that,

I saw it standing out clear and insistent - the dreadful fear that dominated their lives. Wherever I travelled. I saw stark fear. Fear lay in the eyes of every man in this country. It was a dull silent fear that would not set a man running. but the terror of waiting for a blow from a blind side. The people were afraid of the brigands who raided them and cut them with knives if they did not pay. They were afraid of the gendarmes and police who beat them and imprisoned them. They were afraid of their neighbours. Greek and Armenian watched Turk, and Turk watched Greek and Armenian. No man knew what political changes or what new evil tomorrow might bring, and the people waited on tip-toe (1925, p.162).

Some of the brigands involved in the raid were captured. Brigandage in the area was slowly destroyed restoring partial safety to roads and villages. However, as Armstrong tells, while the small bands could be eliminated easily, the large and powerful ones could not. There were still both Greek and Muslim bands that operated in the area and many incidents occurred between the two. One of the strong Muslim bands was that of Laz Tahir's, who had taken to the hills to fight the Greek troops and had become a local hero (1925, p. 178). Laz Tahir captured a rich Albanian and held him to ransom. He was killed by one of the members of the hand to obtain the pardon that Armstrong had promised to Laz Tahir (1925, pp. 200-202). 
In the meantime the Turks were smuggling arms from the depots in Istanbul area into Anatolia.[17] Armstrong claims that. in Istanbul, the Ministry of War and all departments began openly to work for the Nationalists. They were providing arms, money, and men to the Nationalists in Anatolia (1925, p. 108). Armstrong writes that this extensive pillaging of war material from Istanbul depots could not be prevented by the Allied Forces. He claims that the French authorities were heiping the Nationalists to ship away the war material. He also notes that. the guards on nearly all the depots were Turks and all helped to get away munitions to fight the Greeks (1925, pp. 142-143). In addition, in Eastem Anatolia there were a large quantity of arms and munitions which had not yet been surrendered. Price, who was in Turkey for a newspaper assignment, writes that a large quantity of munitions was dug up from old Russian depots which had been concealed during the Russian advance of 1915-1916. Even more were smuggled across the Black Sea (1923, p. 144).

Adivar's memoirs provide a clearer picture of more traditional forms of banditry exercised in Anatolia. Some of the activities of these traditional bands helps to situate their role in society at a broader level. She tells the story of some of the activities of the bandit bands around the Burdur area. As she notes, referring to the region between Isparta and Adalia. “one was assailed by the robbers who were pestering the Anatolian region in bands. The kind of fate one would meet at their hands depended on their humor of the moment and on the working of their imagination. They had a pretty original imagination for disposing of you, and if they let you live they did it in a way that made you remember them always" (1928. p. 330). In early 1922 Adivar was travelling in this area - on lis way back from 
Antalya to Ankara - with a group of people and they were all armed. including herself. I

quote from her memoirs.

At Kirk-Geuz (Kirkgoz) inn the stories about bandits were the dominating subject of conversation. The Haji Murad band was the terror of the region. Among the many original ways of killing people (he did not always kill them) was the methoxl of boiling olive oil and pouring it over the body of the unfortunate victim. Rana Hanum, the doctor's widow, was nervous. Dr. Hassan Ferid consoled her. "He doxes it only to those who have capital; he is full of revolutionary ideas; he might even be kind to you when he knows that you are poor. But when he says. 'Lic on your ficce and throw down your gun and purse.' you must do as you are told." Then he told us the gossip of the travellers who had the experience. When the ominous voice shouted from behind the rocks on the steep and narrow road in the Tchubouk Pass. "Lie on your face and throw down your gun and your purse. sometimes forty men would flop down on their faces in a row and wait till the bandits went through the business of despoiling them. It was the position of the pass which made it possible. Two armed men could stop a whole army (1928, p. 333).

She continues with her story,

When we had passed the region where we might have been surprised by the Haji Murad band... we felt relieved. We were then passing across the plains of the Chine...from an old mill in the plain eight men had come out and were walking toward the road...And as we went slowly they came nearer and nearer, until we could clearly see each other's faces. The chief wore a soldier's coat. He wore it, I heard later, to show his victory over the officer from whom he had taken it...My eyes were fixed on the bandits, and their chief's eyes on mine. I believe he was taking me for a young officer and was speculating on my wolf fur...But at this moment the chief after reaching the road tumed back, and the others followed him. He did not wish to fight. I am almost certain that he would have ordered us to lie down if we had not stared at him hard and coolly... When we entered Bordour and went straight to the hotel, we found it full of people with complaints. The man was Mahmoud, the bandit chief, and the eight men had that very day stopped three convoys. The coat he had got i.om an officer. Mahmoud must have been a man of some courage and some humor too, as he exhibited himself in this coat in the neighborhood of Bordour. The gendarmes marched out the next day in his pursuit. They said that it was an impossible task until the army could help. But the hands of the army were full, and it had to let things go on as they were in Antalia for the time being (1928, pp. 334-335). 
Adivar tells the story of what she witnessed the next day while waiting for the boat they had to take in order to continue with their travel. What she observed is important with regard to the perspective held by a group of bandits. As she writes.

I heard angry voices...There were some thirty chained convicts, who were protesting because the fare of the boat was demanded from them. Rebellion was written all over their faces; they had belonged to various bands who had done a lot of robbing and a number of murders - in short, men who had gone to the mountains. One of them in front had an arresting face and voice..."Did we ask to be transported?" his voice rang out over the angry growls of the others. "We shan't pay; what is the difference between the robbery on the mountains and the robbery by governments?" It was the eternal note of revolt against authority, very often against the established tyrannies protected by the law. Yet he had been a soldier in Gallipoli and did know how to fight within the law too. It was a mere chance that society had turned him into a robber chief (1928, p. 336).

To conclude this section, social banditry in Anatolia was an established and permanent form of peasant resistance against central authorities.[18] Banditry was not only practised for individual gain but against the authority of the government. Bandits often attacked the local representatives of the state, such as the gendarme, as proof of their power over state authority. Bands formed by non-Turkish (e.g. Kurds) and non-Muslim (e.g. Armenians and Greeks of Turkey) ethnic minorities were the result of a different dynamic which I discuss in sections IV.2.4 and IV.2.6 of this chapter. Banditry, as one aspect of peasant movements, became part of the nationalist movement during the Independence War and, as Hobsbawm suggests, bandits were capable of mobilizing the peasantry. The peasantry either revolted against the Nationalists or allied with them against the invaders under the leadership of powerful bandit leaders. In both cases banditry had an impact on the Turkish Revolution which I analyze in detail in Chapter Five. 


\subsubsection{Internal Revolts During the Independence War}

Many revolts took place during the first years of the Independence War, and bandits and deserters were involved in these movements. The most important revolts which occurred during the years of 1919 and 1921 are as follows: Ali Bati. Seyh Esref. Bozkir. Anzavur. Duzce, Yozgat, Zile, Konya, Milli tribe, Kocgiri. and Pontus revolts. The Pontus revolı continued from the beginning to the end of the War of Independence It was a revoll carried out by the Greeks of Turkey living around the Samsun area. located at the northern shore of Anatolia. I will discuss this revolt when looking at non-Muslim opposition to the government. There were numerous other movements and rebellions which occurred during this time period and spread over a vast area. In addition to these uprisings Demirci Mehmet Efe and Cerkes Ethem themselves, who suppressed most of the revolts mentioned above, revolted against the Ankara government in late 1920 and early 1921. Their revolt accelerated the formation of the regular army. I discuss the Cerkes Ethem revolt and the Green Army separately in section IV.2.5.

As Smith puts it, these revolts were led by royalists, and Islamic sheiks, and in sume cases were supported by the British and other Allied forces (1959. p. 43). The Ali Bati revolt (1919) was led by a Kurdish tribe leader named Ali Bati, in Nusaybin. He was an influential tribal leader and he argued that the sultan gave him the right to protect the region. Kabacali claims that he was also looking for ways to negotiate with the British for their support. Ali Bati released some of the prisoners from the prison and collected money from the civilians by force. The forces of Ali Bati was defeated by the army backed by militia forces of the region, and he was killed (Kabacali 1991, pp. 28-29). The 
region was one of the areas troubled with robbery and banditry. Two other revolts took place which were religiously inspired; the Seyh Esref revolt (1919) which took place in Bayburt (located in Eastem Anatolia), and the Bozkir revolt (1919) in Konya (located in Central Anatolia). Both revolts were led by religious leaders who supported the Sultan and the Caliphate against the Nationalists.

The Anzavur revolt was one of the important ones which was led by an old Circassian man, who revolted twice (1919 and 1920). He was given the title of pasha by the sultan and sent against the Nationalists. As Smith quotes from Ali Fuat Pasha's memoirs of the National Struggle, who was one of the leaders of the Nationalist Movement, the royalist forces of Anzavur declared the Nationalist Forces the enemies of Islam and the Caliphate (1959, p 44; Igdemir 1973, pp. 56-57). Circassian Anzavur commanded a large armed force. and he tried to enrol supporters to his army by arguing that the National Forces were against (Islamic) religion (Abadan 1972, p. 132). Many hold the belief that the Anzavur revolt was supported by the British to secure order in the area of Dardanelles (e. g. Aybars 1988, p. 16: Kinross 1965, p. 227: Mert 1992. p. 858). Abadan, on the other hand, argues that the Circassians in the Place may have influenced him to revolt against the Nationalists (1972, p. 131).

The forces of Circassian Anzavur and other similar anti-Nationalist forces were known as the 'califate forces' (Kuvayi Inzibatiye), including those forces either sent directly from Istanbul by the sultan or those formed by sultan's emissaries in Anatolia. Smith argues that, the Caliphate Forces were supported by the British and Greek forces (1959, p. 34). A British document confirms this view. According to the document. "Ferid wants to know 
how far Allies will support Government in organising and utilising these moventents. I have held out no hope of active British co-operation in operations against national forces: in Asia Minor. I have. however, taken sympathetic view, and request that we should enable Government to make the best use of movements by allowing military matcrial to be used for equipping anti-Nationalist forces" (FO. 406/43. p. 289. no. 172 no. 9. in Simsir 1975. pp. 29-30).

Here it is necessary to note that the Circassians [19], as one of the ethnic groups of the Ottoman Empire. did not act in a unified way during the War of Independence. While many Circassians took part in counter-revolutionary movements, others formed numerous nationalist militia bands supporting Mustafa Kemal's movement (Ment 1992. p. 860)). Still others joined the Greeks and fought against the Turks.

Circassian Ethem defeated Anzavour's forces: Anzavur himself managed to excape. However, as Abadan notes, later in 1921. Anzavur requested permission from a British General to command part of the Greek army to crush the Nationalists in Anatolia. When ine Nationalists found out about Anzavur's plan, the band headed by Albanian Rahman (Amavut Rahman), who was in charge of hunting Anzavur. ambushed and killed him with the help of Mehmet Efe (Abadan 1972, pp. 132-133). In the meantime the 'Caliph' ie Army' vanished. Some of the members of this force joined the National Forces, and some took refuge in the areas where the British had control (Hicyilmaz 1993, p. 156).

Other anti-Nationalist rebellions occurred in Bolu and Duzce (1920), led by some Circassian chiefs who were personally attached to the sultan. In addition. as Adivar 
relates. the Turks from Gerede - a purely Turkish district - and the neighboring villages revolted against the Nationalists under the influence of the religious decree issued by the Caliph condemning the Nationalists. There were also rumours about abundant British gold that had been brought by the emissaries of the sultan to support the rising - though. as Adivar notes, there was no evidence of its existence (1928. p.153). Those who participated in the revolt released the prisoners from the prisons of Duzce. and in their place imprisoned military officers and government officials. The Istanbul government supported this revolt. It was again Circassian Ethem's forces who suppressed the revolt in Bolu. He executed many rebels without Mustafa Kemal's consent after he entered to Bolu.

One of the most troubled regions was the district of Bolu and revolts in this area did not come to an end easily. As Adivar notes, "between Bolou [Bolu] and Angora [Ankara] village after village was rising. We had no force strong enough to prevent them, and in any case we never knew when or where to expect an outbreak. It was mostly mob force which suddenly flared up. killed, and destroyed. them dispersed by itself" (1928, p 163). In Adivar's view, the people were torn between the Nationalists and the caliphate army. "and sometimes rising in wild revolı and killing many whom they supposed to be Nationalists and infidels: somehow the two went together in the minds of the people. It was also a rule among them to kill all who shaved and wore collars" (Adivar 1928. p. 165). They killed those who shaved and wore collars since it symbolized Westernized nationalists. 
Two other revolts took place in 1920: the Yozgat and Zile revolts. It is argued 'hat the Zile revolt was organized and led by the Ottoman government against the Nattionalists. Many bandits were involved in both revolts which were repressed by the Nattional Forcien.

Another important revolt that took place in Octother. 1920 was the vecond Kinnal revilt. According to Aybars this revolt was supported by the Istanbul government. and it was the military deserters that were involved in the revolt ! 1988, p. 16). Their leader was a bandıl called 'Delibas' and there were five hundred military deserters under his conmand. Si'nk: religious figures (hocas) were also among the leaders of this movement (Abadan 1972. p. 137). As Adivar notes, the whole of the large province, with most of its towns and villages, took part in this revolt. In her words. "they formed a peasint government of their own in Konia which functioned for a few days till Colnnel Refet's forces reached the town" (1928, pp. 195-196). The revolt was again repressed by the National Forces. and some of those who took part in the movement joined the Nationalists which was their only means of survival.

The revolt led by the Milli Tribe (1920) aimed at establishing an independent Kurdistan in Eastem Anatoiia. This revolt was suppress:d by the regular army back od by some other tribes living in the area (Kabacali 1991, p. 32). About the same time in 1920 another movement occurred, known as the Cemil Ceto incident. Cemil Ceto. who was the leader of the Bahtiyar Tribe. by uniting the leaders of several other tribes, tried to establish an independent Kurdistan government in the area of Garzan. It is argued that the Kurdish organization established in Istanbul, known as the 'Kun Teali ve Teavun Cemijetı'. 


$$
\frac{3}{3}
$$


encouraged such movements for the establishment of an independent Kurdistan. Thıs revolt was suppressed by regular military forces (Kabacali 1991. p. 33).

The Kocgiri revolt (1921) was also led by a Kurdish-Alevi [20] tribe named Kixgiri living in the area between Sivas and Erzincan. It is assumed that this tribe consisted of at population of forty-thousand (Mumcu 1991, p. 35). It was one of the most important revolts which again was related to the 'Kurdistan Teali Cemiyeti'. The leaders of the Dersim and Kocgiri tribes announced that they would suppon Ankara government on the condition that they would recognize an autonomous Kurdistan in Eastern Anatolia. Those tribe leaders who took part in the revolt were forcing the Ankara government for an independent Kurdistan and they requested that the terms of the Sevres Treaty be applied. which laid the grounds for independence for ethnic minorities. They also requested that the Turkish civil and military officers evacuate the regions where the majority of the population were Kurdish, and release all the Kurds from the prisons of the area (Mumcu 1991, pp. 36-37).

The revolt spread over a wide area in a short time period. The Kurds killed some Turkish peasants and looted many villages. It was suppressed by the regular forces, in this case the 'Central Army', with a backing of irregulars who were supportive of the Nationalists. Among these irregulars were the forces of Topal Osman who was in charge of the Black Sea coast against the Greeks of Turkey living in the area. In addition, as Mumcu states, some Kurdish leaders and tribes, who favoured the forces of the government, helped the Central Army in suppressing this uprising (Mumcu 1991, p. 38). More than five hundred participants in the uprising were killed during the suppression. Thiny two Kurdish 
leaders, together with four-five hundred participants were also arrested. Among these. seventeen were sentenced to death and the remaining were sentenced to imprisonment. Still another one hundred participants were sentenced to death in-absentia. Mumcu refers (i) the report prepared by Nurettin Pasha, who was the commander of the Central Army, according to which many well known bandit leaders and bandits (eskiya of the east) were involved in the Kocgiri Revolt. Many of these killed (more than one hundred and fifty) and arrested were bandits. In addition to these, more than two hundred military deserters were arrested (Mumcu 1991, pp. 39). The Kocgiri Revolt was one of the most important Kurdish revolts that took place before the proclamation of the republic in 1923. Although it was not a bandit rising, bandits and military deserters became the influential participants of the revolt led by the Kocgiri tribe.

While the Kurdish revolts discussed above were scattered and loosely organized, the revolts which occurred after 1923 were much more organized and had widespread consequences. I discuss the Kurdish movements that followed the establishment of the new Turkish state in section IV.3.3 of this chapter.

In sum, the revolts which I described above were not well organized resistance r.. vements. While some were religiously inspired and often led by the royalists, others were mostly ethnic movements. The Turks, Circassians, and the Kurds were all involved in these local revolts that took place between 1919 and 1921 . As Ergil argues, the peasants had no institutional autonomy or leadership. Both the landless peasants and the majority of landed peasantry were dependent on big landowners where there was no room for indigenous peasant organizations and leadership. In Ergil's view, "the big landlords 
wished to preserve the traditional social and economic institutions in the countryside. Their alliance with the Nationalist bureaucracy (led by Mustafia Kemal) left the 'status quo' in rural Turkey unchallenged by the new state apparatus. A gieat majority of the landlords had not abandoned the countryside for city life. There was no 'authority gap' in the Turkish countryside which could be filled with peasant organizations and leadership" (1974. p. 84). The link between the peasantry and the local leaders did not allow any room for struggle between the two. Any form of intervention to the existing order of things seems to have played an important role in mobilizing local power holders. supported by the peasants, to resist. In addition external threats either by foreign occupation or by minority groups had motivated resistance among the piasantry. These movements were mostly reactionary since they remained at the local level and had no program to follow. I analyze the impact of these revolts, together with the impact of nonMuslim resistance, on the form of the new state more fully in Chapter Five.

\subsubsection{Non-Turkish Opposition: Kurdish Resistance}

It is necessary to provide a closer look at the Kurdish population since they continued to play an important role in Turkish history after the proclamation of republic in 1923, as they still do in Turkey today.

The Kurds, now scattered in Turkey, Iran, and Iraq, were incorporated into the Ottoman Empire while some were incorporated into the Persian Empire in the sixteenth century. As van Bruinessen notes, "most of the contemporary sources on this period have the perspective of the ruling classes (or the ruling strata). History is presented as an 
adventurous struggle between Turkish and Kurdish military and political leaders; of the common people and their role we learn next to nothing" (1992. p 141). Before Sultan Mahmut II succeeded to the throne (1808-1839) Kurdish leaders were semi-independent rulers within the empire. In response to Sultan Mahmut's efforts to reestablish centralization the conflicts between the Ottoman government and the Kurdish leaders accelerated. An important development was the formation of Kurdish tribal militias in 1891, which were formed by Sultan Abdulhamid and named 'Hamidiye', after him. I briefly look at the formation of the Hamidiye for the conflicts experienced then shed light on later developments. In addition, it is necessary to look at the roots of the conflicts between the Ottoman government and the Kurds which later became essential part of the dynamic of the state formation process in Turkey. The 'Kurdish problem' is also linked to the Armenian minorities in the Ottoman Empire who largely shared the same territory, which was mainly Eastern Anatolia.

According to van Bruinessen the militias were formed in response to the growing Russian and British interest in the Armenian question. The Hamidiye, recruited from nomadic or semi-nomadic Kurdish tribes, were led by tribal chieftains to secure order in the eastern provinces of the empire. With this development some Kurdish tribes gained more power compared to some others. Hence the regional balance of power changed considerably. In van Bruinessen's words, "in times of new crises the Kurds, as Muslims, might conceivably rally to the sultan-caliph's pan-Islamic appeals and oppose the Armenians and/or Russians; they might just as well not. It is against this background that the formation of the Hamidiye had to be seen: as a means of making it more rewarding for the Kurds to be 
loyal to the sultan, and as the most effective way to police eastem Anatolia“" $1092, \mathrm{p}$. 185).

The Kurds were used as the armed forces against Amenian activities. Gates, who worked as a Christian missionary in Eastem Anatolia for many years from 1880 onwards. tells numerous stories about Kurdish attacks on Ammenians in the mid-1890's (1940. p. 101 111). He writes. "the Ottoman sultans looked upon them as an aid to keep the Armenians in order and to check any attempts that the latter might make to achieve independence" (1940, p. 104). The Hamidiye, the armed Kurdish forces, played an important role in the attacks against the Armenians in 1894-1896. After these incidents the Armenians in the Sasun area of Eastern Anatolia rebelled against the Ottoman government to protest both the taxation by the government (that had started to collect taxes directly). and to protest the Kurds who continued to take their traditional share of Armenians' crops. This revolt was suppressed by the Hamidiye in a brutal way.

Gates argued that the attacks on the Armenians which took place in 1895 were carried out under orders from Istanbul. He claims that although the Kurds were used as agents in the attacks upon the Armenians they were under Turkish direction, and the Turks took part in these attacks together with Kurds (1940, p. 104). In 1896, according to Gates, this time it was not the Kurds but the Turkish soldiers and the Turkish population who were engaged in the attacks against the Armenians. In this incident, he argues, the Kurds were only interested in plunder (1940, p. 127). Van Bruinessen, on the other hand, referring to all of the attacks on Armenians in Eastern Anatolia, argues that while these attacks were carried out on orders of the sultan. the Hamidiye's own initiative played an important role. He 
claıms, "there were no attempts at systematic expulsion or extermination of the Armenians. In fact, the civil administration tried to undo some of the harm the Hamidiye had wrought. A British consul reported that, "Much of the booty seized by the Kurds in the Erzeroum area in August and September of 1894 was in the process of being returned to its Armenian uwners by the government"' (van Bruinessen 1992, p. 189). The Hamidiye was not formed to exterminate the Armenians. However, its formation had the unforeseen consequence of strengthening some Kurdish forces which were later to engage in bloody territorial struggles against the Amenian population in Eastem Anatolia (Avcioglu :986, pp. 1088-1089).

In van Bruinessen's view, the formation of these irregular tribal forces also helped the Ottoman government to have better control over the Kurds.[21] As Gates argues, the Kurds, who were Sunni, normally lived for the most part by plunder, and were often in open revolt against the government $(1940$, p. 104). The Kurdish tribes became attached to the Ottoman government in a different way after the formation of the Hamidiye. The Hamidiye were trained by the officers of the regular army and they were provided with paid employment and arms to carry out raids. Their families were exempted from most taxes. According to van Bruinessen, with these developments, the Kurds developed a strong loyalty to the sultan personally. Being a Hamidiye commander gave more power to some chieftains who used their power to end the ongoing disputes between tribes. It also prevented tribal crobination against the Ottoman government (1992, p. 186). In this way the sultan maintained his control over the Kurds.[22] However. it would be a mistake to assume that all tribes were loyal to the government. 
The Hamidiye system divided the Kurds along new lines of power relations by establishing a different kind of relationship with the Ottoman government. The Kurdish tribes never became unified along nationalist or religious lines since the relationship between the tribes and the government often shifted with the developments within the country.[23] During the War of Independence and even later there were many tribes in favour of the sultan-caliph as many as those supporting the Nationalists.

The Hamidiye continued to play an important role in Turkish history after the Young Turk Revolution of 1908 and in its aftermath. The Young Turks disbanded the Hamidiye and incorporated some of its members into the regular army. However, as van Bruinessen states. the Kurdish tribal units were seen as a necessary complement to the regular army with regard to the problems experienced in Eastem Anatolia. The Hamidiye, therefore. were reorganized as militias and became more integrated into the amy. These units were used in the Balkan War of 1912-1913, and on the eastern front during World War I (Kabacali 1991, p. 24). In addition they played an important role both in the War of Independence, and in some of the Kurdish revolts against the Ankara government. In van Bruinessen's words, "it was from the ranks of the commanders of these militias, who had helped Mustafa Kemal (Ataturk) regain independence for modem Turkey, that the Kurdish nationalist party, Azadi ['Freedom'; established in 1923], drew its membership" (1992, p. 189).

The role played by the shaikhs in the revolts that occurred before and after World War I is an important one and needs to be discussed briefly. The shaikhs began to achieve the role of political leaders in early nineteenth century. Due to changing internal balances 
government officials did not have the authority and legitimacy to negotiate the settlement of serious tribal conflicts. However, the shaikhs could settle conflicts between tribes which in turn gave them political authority over some tribes (van Bruinessen 1992, p. 229). The shaikh is the holy man, the object of popular devotion, and the leader and instructor in mystical brotherhoods. They adopt the role of prophet. Thus they are the ideal mediators in conflicts who are also potentially capable of mobilizing large masses (van Bruinessen 1992, p. 210).

It was the shaikhs who mostly led the revolts in the Ottoman Empire and later in Turkey.

These movements of revolt were similar to movements of millenarianism. van Bruinessen observes,

several of the early proto-nationalist rebellions of the late nineteenth and early twentieth centuries showed distinctly millenarian features. Typically led by shaikhs, they hoped for the establishment of a radically different society, expected to come about as a result of largely symbolic action. They were reactions against the penetration of Western influence and to the challenge to traditional values that this represented. Protest was couched in religious terms, and the participants acted in blind obedience to the shaikhs, whose charisma was apparently believed to make strategic considerations unnecessary (1992, p. 250).

\subsubsection{The Green Army}

I continue with the developments that followed the suppression of the internal uprisings discussed above. I refer to the organization known as the 'Green Army' and the establishment of the regular or conventional army.

From time to time cruel methods were used by the irregular chiefs of the National Forces in extorting money and in punishing those who had participated in the risings which often 
resulted in large number of neutrals rising against the Nationalists and joining the other side (Adivar 1928. p. 153). However, the irregulars were still respected by many. I tind Adivar's remarks about the irregulars useful at this point.

For some reason I was losing my objection to the irregulars. They seemed such boyish creatures with their personal ideas of right and wrong. mingled humanity and cruelty, all subservient to a very definite sense of the inviolability of the given word. They had an invincible resentment against the government. considering all governments promise-breakers and capable of performing any dirty trick in the name of law, and were very well aware that the Nationalist government, to whom they happened to be useful at the moment. would as likely as not have them all killed if it suited them to do so. Yet they would always consider themselves the faithful children of Turkey (1928, pp. 112-113).

The irregulars were famous among the civilians at the time. This was especially reflected in the coming of Circassian Ethem to Ankara after more or less taking control of the rising in Bolu. Adivar describes this event. "When he came the streets were thronged with his men, all of them beautifully equipped in a wild irregular fashion. The sight was rather imposing. There were even women fighters. Edhem himself was the most picturesque of all. He was received with great honors. Mustafa Kemal Pasha lent him his car, the only car we had in Angora [Ankara] then; and the National Assembly stood up and greeted him with loud cheers" (1928, p. 167).

Opposition to a regular army was widespread even among military officers. Adivar write: that,

It was clear that a regular amy was an unreliable instrument, as it would not fight with the reactionaries who were threatening to bring the Nationalist resistance to an end. The only power we could depend on at that moment to establish our prestige was that of the irregular revolutionary bands. And that had distinct disadvantages. Those scattered units were difficult to unite and impossible to discipline. If some of their leaders were idealists willing to sacrifice everything for 
the cause, most of the rank and file combined with patriotism a lust for power and a greed for gold; and it was obvious that. but for a few exceptions, neither leaders nor led would ever be popular among the people of Anatolia...all were instinctively against the formation of a regular army: all had different ideas as to how the country should be administered: all hated authority and established power: all assumed that the people should be ready to give time. money, and everything else for the cause. But, strange to say, the feeling against the formation of a regular army was expressed even by very distinguished soldiers(1928, pp. 156-157).

In 1920 some of the guerilla forces became unified under the name of 'Green Army' which later joined with the forces of Circassian Ethem. Circassian Ethem. who had fought in World War I and became rich by collecting ransom, was strongly against the formation of a new regular army. Colonel Arif in his memoirs writes about Ethem in this way:

Edhem's men numbered about three thousand and were gathered from different sources. They were all mounted and between them had four cannons and a hundred machine-guns. Their paper. the 'Yeni Dunya' (the New World). published in Eskishehir. continually printed articles against militarism and the formation of a regular army. Their center was Kutahia and they were in direct communication with Angora. The privates of this irregular army received from fifteen pounds to thirty pounds a month. which was three times as much as what was paid to those of the regular army. And the regulars were badly clad and irregularly paid, besides being under a rigid discipline. Any poor and shabby private could desert his battalion and join the irregulars, where excellent equipment, a good horse. a silvermounted whip, a belt of shinning cartridges, a better and regular pay, as well as an easier life, awaited him. Why should any one be a regular soldier under such conditions?" (quoted in Adivar 1928, p. 231).

Circassian Ethem. while in Eskisehir joined the organization known as the 'Green Army' (Yesil Ordu). According to Harris, "as a personal rival of Ataturk's, Ethem no doubt saw in the communist movement a source of support against the Kemalist leadership" (1967. p. 77).

It was in response to the Green Army that Mustafa Kemal established the official Turkish Communist Party', in October 1920. His aim was to undermine the power of the Green 
Army on the one hand. and to keep control of the communists in Turkey, on the other. There is no agreement as to the aims. size or structure of the Green Amy. While some argue that it was a very minor organizaticn others argue that it was a powerful organization capable of destroying the Nationalists' policies. It is mostly argued that the Green Army was an organization paid by the Soviet goveinment. One perspective claims that the Green Army, which was a form of communist movement, represented a widespread peasant discontent against the Nationalists. It is believed that the 'People's Participation Party in Turkey' (Halk Istirakiyun Firkasi), which was a communist party established in December 1920, was organized by members of the Green Army and the 'Illegal Communist Party'.

As Carr notes the communist movement in Turkey was made up of three different strands. First, a communist movement created and organized by Turkish prisoners of war in Russia: second, the one which originated among the returned exiles from Germany trained in the Spartakist movement; and third, those indigenous movements throughout Asia Minor not strictly communist in doctrine or organization, but professing sympathy for communism and for the Soviet form of government (Carr 1953. p. 298). In Carr's view. "the indigenous Turkish movement of sympathy for communism which grew up in 1919 was mainly of peasant origin and was rooted in agrarian discontents. Its oven expression was the creation of a multitude of local Soviets which became for a time the effective organs of local government" (1953. p. 299). Carr claims that it was from among these supporters that the Green Army was organized in 1920, and that the members of the Green 
Army were recruited from the small and landless peasants who formed a major part of the National Forces (1953, p. 300).

According to Berkes. on the other hand. the Green Army represented just one of the many guerilla groups of the period. He argues that.

The Green Army was not an expression of peasant discontent. It was organized to combat the local uprisings which seem to have come. not from peasant, but from semi-feudal reaction to the national movement. Uprisings representing this reaction had no revolutionary characteristics. One of them. led by a Seyh Recep at Sivas, was an anti-Nationalist struggle on behalf of the Caliph. There were several others of a like nature. A certain Esref. who led an uprising in the Eastern provinces, styled himself as the expected Mahdi and the Protector of the Seriat. The uprisings at Durce and Bolu. Yozgat, Zile, and Konya were instigated by the esraf, seyhs, and hocas in the name of preserving the Seriat and Caliphate. All were anti-nationalist; none aimed at an agrarian popular revolution. The real peasant unrest was shown in the peasants' attempts to avert the burdens of another war. Their desertions threatened the dissolution of the already weak regular army far more than the Allied policy of disarming. These desertions were another factor in the creation of the Green army $(1964$, p. 441$)$.

It is difficult to see the Green Army as an expression of a revolutionary peasant movement as Carr suggests. Tuncay claims that, the Green Army was initially established by Mustafa Kemal's close friends. Mustafa Kemal opposed the Green Army only after Circassian Ethem took active role in this organization since Ethem was the leader of a powerful armed militia force (Kuvay-i Seyyare) (Tuncay 1991, p. 85; Inonu 1992, p. 226). In this context, the Green Army cannot be seen as an organized revolutionary movement determined to change the world in favour of the peasants.

Turkish peasants did not demonstrate a unified movement. Regional differences played an impontant role in keeping apart various movements which cannot be characterized as 'revolutionary'. While in some regions military desertion was a big problem, in some 
other regions peasants voluntarily acted in unity whenever threatened. For coample mam! bandit bands became part of the National Forces whereas others rebelled against the Nationalists. Steinhaus, too, argues that it is misleading to see the Green Army as an organized body of peasant resistance. As he emphasizes, militia bands and bandı bands varied both socially and geographically and this should be taken into alcount when analyzing the Green Army (Steinhaus 1974. p. 97).

There is yet another perspective on the Green Army. In Harris's view, the Green Army's functions were political and it had little to do with military organization. Harris claims that. "the Green Army appears to have been formed with the connivance of the Ankarat Government, which saw in it a means to impress the Kremlin that the Turks were sincere in wanting a social revolution on the Russian model. Moreover, in order not to fuel Westem fears that the Kemalists might in fact be Bolsheviks, the Green Army operated as a secret society, recruiting its memhers from the elite. not from the masses. Soon, in addition to its Ankara headquarters, the Green Army managed to set up a branch in Eskisehir. But. though its members travelled fairly extensively, it established no other formal subsidiaries" (1967, pp. 69-70). Harris's position also supports the argument that the Green Army was not really a 'peasant movement' with a program for a communist regime.

The more Circassian Ethem gained power, the more he presented a problem for the Nationalists, and these developments set into motion the establishment of a regularconventional army. By the end of 19.20 the irregular forces were slowly merged into the newly formed regular army which was still in the process of formation. Circassian 
Ethem. in December 1920, attacked and disarmed the regulars in Kutahya and sent the soldiers back to their villages and took a position against the National Assembly. He refused to be under the command of Ismet Pasha and to take order from either him or Mustafa Kemal. After their success in repressing local revolts the bandit leaders refused to fight as they were ordered to. In response to these developments the forces of Circassian Ethem was openly attacked by the newly formed regular army for the first time in January, 1921. Ethem landed all their guns to the Greeks and this caused many of his supporters to desert him. Ethem himself fled to the Greeks. After these developments drastic steps against the Turkish communists were taken. The Courts of Independence sentenced many members of the Green Army, including some deputies who had been involved with it.

\subsubsection{Non-Muslim Opposition: Armenians and the Greeks of Turkey (Rums)} In this section I discuss the opposition of the non-Muslim minority groups of the Ottoman Empire, namely the Armenians and the Greeks of Turkey (known as the 'Rum' in Turkish).

To begin with, I start with a brief history of the Armenians of Ottoman Turkey. Armenians were one of the groups who were the subjects of the sultan just like any other group within the borders of the empire. They were not recognized as constituting a separate 'nationality'. Although scattered throughout the Ottoman territory. Armenians had lived in the Eastern provinces of Anatolia for centuries. Yet in many areas the population was never homogeneous, it was mostly composed of Armenians, Turks, and Kurds sometimes 
living in the same village, sometimes living in nearby villages in the same area. American missionaries in Anatolia had devoted themselves to work among the Armenians. They opened schools and hospitals (Price 1923. p. 29. 34). The American schools later became centers of Armenian nationalism (McCarthy \& McCarthy 1989. p. 31).

One of the reasons for the change in the nature of conflicts was connected to the TurcoRussian war of 1877 . The treaties signed after this war procured more privileges for the Ottoman Armenians. However, as Sonyel claims, these treaties

were actually intended to enable the Great Powers, in particular Britain and Russia. to interfere in the internal affairs of the Ottoman Empire...From 1878 onwards various efforts were made by the Great Powers, particularly by the British Conservative and Liberal Governments, for the introduction of reforms in the Ottoman Empire to benefit the Christians, especially the Armenians, who were dispersed throughout Anatolia. One of their earliest unsuccessful attempts was directed towards the establishment of an autonomous Armenian province. which encouraged the Armenian extremists to provoke rebellions (1988, p. 1).

Many severe struggles had taken place between the Turks and Armenians from the Ottoman times. I have already elaborated on some of the major incidents of the mid1890s. This was the period when the Armenians had began to revolt against the Ottoman government. As Selek argues, during this period Armenian nationalists and religious figures started to become influential among the Armenian population with the formation of Armenian Committees in Europe (Selek 1965, pp. 290-291; Gurun 1988, p. 183).

Between 1890 and 1914 Armenians revolted several times. These revolts took place l., 1890 (in Erzurum), in 1894 (in Sasun), in 1895 and 1896 (in Istanbul), and in 1909 (in Adana). These revolts ended with many deaths. Gunun argues that, although some of these events became to be known in the West as systematic massacres of Armenians, they 
actually were the battles between local Turks and Armenians (1988, pp. 184-185). Adivar comments on those massacres which occurred during the Young Turk regime. She particularly refers to the one that occurred in Adana, in 1909. As she writes,

In Turkey massacres are set in motion by a mutual feeling of distrust and fear. It happens in some such way as this: In the Turkish quarters the rumor would go around that the Armenians were going to use their bombs and kill the Turks. As a rule the Turks were without arms in those days; hence bombs in the hands of a revolutionary minority made them nervous. The same rumor would go round in Armenian quarters, and the potential fear and hatred, already worked upon and accumulated by the politicians, would explode, the leaders would disappear, and the people would proceed to throttle each other. Thus the discovery of arms in the Armenian quarters and a personal quarrel between two individuals started the great Adana massacre. Djemal Bey (later Djemal Pasha) was sent as governor after the reestablishment of the Unionist regime; he restored order and became immensely popular especially in the Armenian quarters (Adivar 1926. p. 284).

Here I limit my discussion of the Armenian problem to the events that took place after World War I had started, and refer only to those developments which are relevant for understanding the dynamic that led to the formation of the new Turkish state.

During World War I Armenians and Turks continued to struggle, but the nature of the conflict gained a new dimension. Henry Morgenthau, who was the American Ambassador at Istanbul from 1913 to 1916, describes the situation in Turkey in 1915. "All over Turkey ambitious chieftains had arisen...who were looking for the opportunity to seize their parts of the inheritance...Among the subject races the spirit of revolt was rapidly spreading. The Greeks and the Armenians would also have welcomed an opportunity to strengthen the hands of the Allies. The existing financial and industrial conditions seemed to make revolution inevitable. Many farmers went on strike; they had no seeds and would not accept them as a free gift from the Government because, they 
said, as soon as their crops should be gamered the armies would immediately requisition them" (Morgenthau 1918, pp. 227).

As Selek notes the Armenian-Turkish struggle between the years 1914-1920 was a severe one in which both parties suffered from its consequences. Both sides were involved in massacres. One of the most important events of the war period was the deportation of the Armenians from their land, which took place in 1915.[24] I quote from Price's memoirs who describes the relations between the Ottoman government and the Armenians before these deportations took place.

The Armenian 'block' in the Parliament at Constantinople was holding its 1914 congress at Erzerum in the eastem provinces when the Enver Government entered the war. Government emissaries visited them there and laid before them the PanTuranian project whose immediate object was to throw Russia back. A partition of Russian Trans-Caucasia was proposed, the conquered territory to be divided between Armenians, Georgians and Tartars, each to be accorded autonomy under Ottoman suzerainty. The Armenian 'bloc' replied that if war proved necessary they would do their duty as Ottoman subjects but they advised the Government to remain neutral" (Price 1923, pp. 85-86).

Despite these negotiations at the parliamentary level, the populations were in continuous fear of one another. The Turks feared that the Armenians would unite with the Russians and attack the Turkish armies from the rear (van Bruinessen 1992, p. 271). Moreover, the Ottoman government was concerned that Armenians were a danger to the Empire if they remained in strategic areas, and they intended to keep Armenians out of such areas (McCarthy \& McCarthy 1989, p. 52). As a result, the Armenians were deported from Eastem Anatolia.[25] According to Gurun and Tunaya, approximately 702,900 Armenians were deported (Gurun 1988, p. 290; Tunaya 1984, p. 580). I quote at length from Price's memoirs, who tells the story behind the decision to deport the Amenians. 
Under the 1908 Constitution, the Enver Government had a right to mobilize Armenians of military age as well as Turks, but armed opposition broke out at once, notably at Zeitun. a town of Armenian mountaineers who had long enjoyed an almost complete local independence. Along the eastem frontier, Armenians began deserting to the Russian Armies and the Enver Govemment. distrusting the loyalty of those who remained, removed them from the combatant forces and formed them into labor gangs... With this situation in his rear, Enver Pasha crossed both the Russian and Persian frontiers but in January, 1915. he was thrown back behind his own frontier by the Russian victory at Sarykamish. This victory fired the annexationist hopes and armed bands of Armenian volunteers began operating behind the Ottoman Armies. On April. Lord Bryce and the 'Friends of Armenia' in London appealed for funds to equip these volunteers, and Russia also was presumably not uninterested in them... These volunteer bands finally captured Van, one of the eastern provincial capitals, late in April and, having massacred the Turkish population, they surrendered what remained of the city to the Russian Armies in June. The news from Van affected the Turks precisely as the news from Smyrna affected them when the Greeks landed there in May, 1919. The rumor immediately ran through Asia Minor that the Armenians had risen...By this time. the military situation had tumed sharply against the Enver Government. The Russian victory at Sarykamish was developing and streams of Turkish refugees were pouring west-ward into central Asia Minor....It does not seem reasonable to assume that this moment, of all moments, would have been chosen by the Enver Government to take widespread measures against its Armenians unless it was believed that such measures were immediately necessary. Measures were taken (Price 1923. pp. 86-87).

Armenians argue that they were deliberately massacred during the process of their deportation to Syria and Iraq. Turks, on the contrary, refuse the claim that there was such a deliberate plan. As McCarthy \& McCarthy argue, "no evidence of any central government plot to annihilate the Amenians has surfaced, although Armenian sources have produced documents later proved to be forged... The issue may never be resolved. because those for whom Armenian genocide is an article of belief will always claim that Ottoman archival documents are false" (1989, p. 54). However, because the Amenians were not well protected when being deported, they were attacked by tribes and bandits whenever possible and did die from murder, starvation, and disease (McCarthy \& MeCarthy 1989. p. 55). Armenian sources claim that 2,000,000 Armenians were 
massacred while being deponed (Gurun 1988. p. 290). The Turkish sources, on the other hand, argue that a total of 300,000 Armenians had died during World War I (Gurun 1988. p. 290: Tunaya 1984. p. 580). McCarthy \& McCarthy, as opposed to the guesses that are usually published, claim that almost 600,000 Anatolian Armenians and more than 2.5 million Muslims had died between 1912 and 1922. In their words, "in the war zones of the East, more than half the population of some provinces, Muslims and Armenians, had died. The deaths of Armenians by province cannot be ascertained, but in the war-torn provinces mortality must have been especially great for both Muslims and Armenians" (1989, p. 65).

In this context Selek and Avcioglu note that, although the Ottoman government promised to confiscate Armenian properties through local commissions, sell their properties, and pay them back when they return to their homes, this did not happen. For many misused the existing conditions and became 'rich' (Selek 1965, p. 292; Avcioglu 1986, p. 1141 ). According to Selek, when the Ottoman Empire lost World War I, the Turks of Eastern and Southern Anatolia began to fear the return of Armenians to their homes with the possibility of a desire for revenge against the Turks. Selek claims that this is closely connected as to why the 'Society for the Defense of the Rights' was first formed in Erzurum, in Eastern Anatolia. It also explains why the Erzurum Congress (which was the first gathering of the Nationalists) was held in the same city (Selek 1965. p. 292; Avcioglu 1986, p. 1160).[26]

Certain parts of Eastem Anatolia changed hands between the Armenians and Turks four times during the years 1916-1920. During each war the soldiers and the civilian 
population was forced to leave from their homes and land. The ones who preferred to remain were massacred by the other side (Selek 1965, p. 293). In 1916 both the Russians and Armenians invaded Eastern Anatolia, and Russians advanced beyond Erzincan pushing Muslims to the south and west. After the Bolshevik Revolution Russian troops were withdrawn from the occupied territories and they left most of their arms to the Armenians in Anatolia. The Transcaucasian Republic established by the Georgians. Armenians, and Azerbaijanis in the southem Caucasus (1917), which was recognized by the Ottoman government, from then on became the base for Armenian attacks. Military units from this republic and from among the Anatolian Armenians took revenge on the Muslims. In 1919 the Ottoman Army fought the Armenians forcing many of them into the southem Caucasus. The Kurds played an important role in these operations (van Bruinessen 1992, p. 271).

Kars was one of the troubled centers in Eastem Anatolia. Besides the Turks there were continuous conflicts between the Tartars and Armenians, both attacking and murdering each other. Dunn writes about many rumours about the Tartars raiding Amenian villages and killing many people (1958, p.146). Tartars were one of the Muslim ethnic groups of the Ottoman society, like the Lazes, Kurds, Circassians, and the Turcomans (Turkmens). The province of Kars, which was evacuated by the Turks in accordance with the Armistice terms. contained many Armenians. However, as Rawlinson notes, the majority of its population has always consisted of Tartars who aimed at establishing an independent Muslim republic of Tartars in Kars. The Turks supported them (1923, p. 156). 
As already discussed the Kurds, 100, were involved in the struggle with the Armenians. Rawlinson writes about the conversation he had with a Kurdish brigand. Omer Aga. in his words. "he began by asking me what the devil I was doing in his country. and what the Allies meant by announcing to the Armcnians that in future his country was to become theirs. Without allowing me time to reply, he then said that, though he was prepared to submit to a mandate being granted to any of the Great Powers, yet he would never submit to any Armenian authority, but would cut the throat of every Armenian who came within his reach" (1923, pp. 212-213). Rawlinson visited another Kurdish chief. Hussein Bey, to take their views on the Armenian problem. Hussein Bey owned thirty-eight villages in the mountains, and ruled his tribesmen with absolute authority as all Kurdish chicfs did. Rawlinson writes that, "He told me he could muster 1,200 mounted men. all well armed. within two days, and had latterly been obliged to do so, as the Armenians had advanced into his country with the intention of carrying out a general disarmament of his people. against which he and all his tribe were prepared to fight to the last man" (1923, p. 201). Hussein Bey also told Rawlinson that his people would be prepared to submit to the government of any European Power, preferably the English. However, he also added that if it was decided to put them under Armenian government, and if European troops were to support the Amenians, they would evacuate their country and go beyond the Turkish frontier. At this time many attacks took place between the Armenians and Kurds. One other Kurdish chief. Eyeep Pasha, had a cavalry of 2,000 men under arms, holding one of the frontiers against the Armenian :. oops who had pillaged and destroyed all the Muslim villages in the area. This was one of the areas included in the territory placed under Armenian control by the Allies. Rawlinson, after meeting with Eyeep Pasha, writes that 
he, too, was prepared to defend their country, and that there were many volunteers from other Kurdish tribes joining them against the Armenians (1923, p. 218).

Considering the 'Armenian problem' in the Eastern provinces, this attitude towards the Armenians can be seen as a widespread one among the Kurds. The Kurds have widely participated in the wars against the Armenians since the Ottoman times.

The Turks had to hand over the province of Kars to the Armenians as advocated at the Supreme Council in Europe. British troops had been sent to the area to see that the operation was carried out. As the British Colonel Rawlinson writes, "in Kars Province itself the immediate result of the announcement of its proposed 'Armenian' future was the organisation of all the Tartar population throughout the district into more of less military bands, supported and armed by the Turks...In every Tartar village throughout Kars Province, at this time, drill and machine-gun practice were daily carried out under the general supervision of both Turkish and German officers" (1923, p. 157).

As Adivar notes, there were two British divisions in the Caucasus. In the meantime, Rawlinson was the chief controller in the eastern provinces, residing at Erzurum. His duty was to supervise the surrendering of Turkish armaments as laid down by the Armistice conditions (Rawlinson 1923, p. 167). Kazim Karabekir Pasha, as the commander of the eastern front, was determined to start a struggle after the removal of these British troops. As Adivar recounts in her memoirs, "The apparent duty of Colonel Rawlinson was to disarm Eastern Anatolia under the threat of those troops and send the munitions and arms out of the country via Armenian Caucasus. This naturally looked like 
taking Turkish arms in order to arm and send the Armenians in the Caucasus against the Turks, thereby repeating the Smyma game. Kiazim Kara Bekir Pasha opposed very seriously the transport of the Turkish arms through Armenian territory, but when he received a firm and absolute command from the central government, trains loaded with the Turkish arms and guarded by a small Turkish military detachment started toward the Armenian Caucasus. But it did not get farther than the frontier, for at Hassan Kale the Turkish Nationalists and the population attacked the train and took the munitions and the arms. It was those arms which Kiazim Kara Bekir Pasha used later in his Armenian campaign, in October, 1920" (1928. p. 46).

The last war between the Armenians and Turks took place in late 1920 where the Turks defeated the Armenians. This war on the eastern front was the first success of the Nationalists. As van Bruinessen argues, "In the spring of 1920, armed Armenian bands started raiding eastern Anatolia from this base [Armenian Republic], in an attempt to take by force the provinces promised at Sevres, now that it became clear that the Turks would never cede them voluntarily. Due to the upheavals of the preceding years the Armenians had become a rather small minority in the eastern provinces, and it seems that all military activity originated from across the border" (1992, p. 273).

Kazirı Karabekir, with orders from the Assembly in Ankara, pushed the Armenians back to their border and forced their government to accept a peace treaty. The treaty was signed between the Armenians and Turks in Gumru (Alexandropol), in December 1920. The borderline decided then, with minor modifications, still stands. In addition, the 
Moscow Treaty between the Ankara government and the Soviet Russians was signed in March, 1921.

Another front existed in the south of Anatolia, namely the Cilicia region. which was occupied by the French. The Armenians were involved in this front as well. As Adivar notes, "the formation of Armenian legions by the French forces aroused a keen sense of resistance and caused untold destruction and human suffering" (1928, p. 19). The Turkish population eagerly participated to this war mainly because the Armenians were part of their enemies on the front (Selek 1965. p. 293). According to a British report on the situation in Cilicia. the Turks of this area strongly believed in the national movement that would save Cilicia from Allied occupation (FO. 371/4185/154797 no. 81, in Simsir 1992. p. 228).

With the contribution of the tales of Turkish refugees from Adana a guerilla war against the Franco-Armenian regular troops had started, and the attacks were carried on mainly by Turkish irregulars (Price 1923. p. 169). After the Turks recaptured Maras, Urfa, and the main towns of Cilicia, forcing the French to withdraw their forces from the region, the Ankara Treaty was signed between the French and Ankara government in October, 1921. During the time the treaty was signed and during the French evacuation most of the Armenians fled to Syria, Cyprus, Egypt, and Istanbul.

I continue with a discussion of resistance from the Greeks of Turkey (Rum). Alongside the Armenians, the Greeks living in Turkey constituted another non-Muslim minority group. Although they were scattered throughout Westem Anatolia they mainly uved in 
Northem Anatolia along the Black Sea Coast. During the Independence War. the Greeks in this area were in continuous revolt with the aim of establishing an independent Greek Pontus state. Pontus is the name in Greek given to the Black Sea Coast of Anatolia (Sener 1992. p. 32). Some portion of the population living in Black Sea Coast are from a different ethnic minority. They are known as the 'Laz', and they are Muslims. During the Ottoman times they mainly lived in the area between Trabzon and Batum. The Lur. just like the Pontus Greeks (Rum), Georgians, Armenians, Circassians, and the Turks were one of the ethnir groups who lived in this region since the Otoman times. The Laz population of this area played an important role during the Independence War against the Pontus Greeks along with the Turks, which I discuss below.

When Greece entered World War I along with the Allied Forces, the Ottoman government decided to depon its 'Rum' community to avoid any contact between the Allied Forces and the Greeks of the Northern Coast of Anatolia. Similar to Armenian deportations of 1915. these Greek deportations were military, and better controlled throughout their course (Price 1923, p. 122). With the signing of the Moudros Treaty the deported Greeks in Anatolia came back to their homes and from then on conflicts between the Greeks and Muslims in Northern Anatolia began to gain a political character. In the Pontus area many Christian militia bands were formed who were attacking the Turkish villagers. The Turks, 100, formed their own militia forces in order to protect themselves from the attacks of these bands (Atay 1958, p. 84). There were more than fifty bands formed by both Turks and Greeks only in Samsun region. There were also various bands formed by the Lazes who protected the Turks (Sener 1992. p. 48). However, Avcioglu notes that the Lazes 
attacked not only the Christians but the Muslims is well (1986. p. 1287). According to a British document. "The Laz bands now operating in the Sanjak are the principal source of trouble. There are probably between two and three hundred such Laz. Most of them arrived during the preceding month upon the invitation of a section of the notables here...Latterly, the Laz tend to show a disposition to make little distinction between Christian and Moslem. I am of opinion that if these Laz bands were attacked and their members killed and scattered, the brigandage problem in this district would be bronght much nearer a solution" (F.O. $371 / 4157 /$ E.88757 no. 2. in Simsir 1992, p. 5).

In addition to these bands there were many robbers and bandits operating in the area threatening public safety to a considerable extent since the beginning of World War I. Widespread looting and disorders were the signs of weak governmental control as was the case in many other regions throughout Anatolia. This was the area where Mustafa Kemal was sent by the sultar, to maintain order in 1919, where he started to organize the movement against the government in Istanbul. According to Adivar. Mustafa Kemal was sent to Samsun for anyikr reason as well which had to do vith the Armenian population. As Adivar puts it,

The Nationalist movement had in the meantime started in the East - always tremendously excited and angry at the mere possibility of an Armenia in their lands. Kiazim Kara Bekir Pasha, as the commander of the only considerable regular Turkish forces in the East, was arming the population from the military depots and getting ready for an effective resistance in case the Allies should decide to create an Amenia in Eastem Anatolia. As there was as yet no Greek army in Smyma, Western Anatolia was in no immediate danger. This strongly rumored movement in the East had frightened the sultan and the Ferid Pasha government, which had succeeded that of Tewfik Pasha. Mustafa Kemal Pasha, who had their confidence in those days. was chosen as the man to pacify the dangerous tendency 
of Kiazim Kara Bekir Pasha. He started for the East as the general inspector of the Eastern forces in May, 1919 (1928. p. 14).

Mustafa Kemal's responsibilities involved the prevention of possible conflicts between the Ottomans and non-Muslim minority groups. namely the Pontus Greeks and Armenians. These represent the critical points of tension which continued to exist during the first years of the National Liberation Struggle.

The landing of British troops in Samsun had initiated more resistance among the Turks. In a report prepared by Mustafa Kemal, regarding the Samsun area, it is noted that the British had released all Pontus Greeks from the prisons, and that the Pontus Greeks attacked many Turkish villages (Sener 1992, pp. 47). Mustafa Kemal took advantage of the situation. When he landed at Samsun in 1919 he secretly met with Topal Osman Aga who was protecting the Muslim population against the Pontus Greeks on his own initiative.[27] His band was the best known, having control over the Giresun area. He attacked the Christians and took part in the process of deporting the Arms.. ns (Sener 1992. p. 49). Not only the Armenians and the Greeks of Giresun, but the Muslims and the Turks as well feared his forceful and brutal band (Avcioglu 1986. p. 1192: Gologlu 1968. pp. 24-25). He declared himself the mayor of Giresun probably because of the support he had received from the local population who saw him as the protector of the population against the Pontus Greeks (Sener 1992, p. 56). According to a British document, Osman Aga, who was the chief of all brigands in the district, ruled the whole district and gave orders to the Governor and other officials (F.O. 406/41, p. 398-400 No. 181/2 no. 83, in Simsir 1992, p. 234). 
Topal Osman was already engaged in banditry before he took part in the ne* - nal movement. In the words of Dunn, an American military intelligence officer in Turkey. "local coast dwellers, called Lazes, had a bad reputation for banditry under a notorious chief named Osman. Not only did Osman's brigands rob and string up the Greek traders who controlled the nut trade. but the Greeks also were deep in the Pontus plot to overthrow Turkish rule. and this agitation intensified the normal outbreaks and 'massacres'"' (1958. p. 109).

Tupal Osman in Northem Anatolia was as important as Circassian Ethem in Westem Anatolia in backing the Nationalists. He had formed a large armed militia force from among the volunteers, known as the 'Giresun Troops' or 'Laz Troops', and cooperated with the Nationalists not only against Pontus Greeks but also against the Kurds (during the Kocgiri Revolt) and against the Armenians in the east (under the command of Kazim Karabekir Pasha). His band was part of the National Forces. He was also fighting with the military deserters, and collecting money (sometimes with force) from the local population. One of Mustafa Kemal's duties in Samsun was to protect the Christian population against the attacks of the Turkish bands and to destroy especially the band of Topal Osman. Instead. Mustafa Kemal asked for his help. This well known bandit. who lived in the mountains till the Nationalists in Ankara became powerful enough, became one of the famous leaders of the National Forces supporting the movement from the beginning to the end.

However. as Price writes, “Osman Agha's terrorism remained as much of a problem at Angora [Ankara] as the Greek terrorism which it sought to overcume, but a solution was 
finally discovered for it when Osman. having shot down 900 Greeks and Amenians in Marsovan in reprisal for the knifing of 200 Turks by Greek troops at lsmid. marched (o) Angora to offer himself and his Laz followers to the Army. He entered Angora as the hero cf a goaded and angry population...and Kemal...incorporated his followers in the Turkish shock troops with whom they were cut to pieces in the Battle of the Sakaria River" (1923. p. 164).[28] Topal Osman's militia forces was about 6.000 armed men in the time when he joined the regulars in the Sakarya battle on the western front against the Greeks, in August 1921 (Sener 1992, p. 81).

The Pontus problem continued until 1922. The Greeks and Turkish irregulars bumed each other's villages and ambushed each other in the fields (Price 1 y23. p. 165). At the end the Ankara government deported all the Greeks in the Northem Coast into the interior of Anatolia which ended the ongoing conflicts in the area since the end of 1918.

The struggle between the Turks and the Greeks was not yet over. The war which took place on the Western front between the two was the last to end. Gurun notes that, although the Turks had to fight with the Greeks on this front. the Amenians were also involved as they supported the Greeks. As he notes, the Greeks enrolled the Armenians in their army against the Turks. The Armenians joined the Greeks during the evacuation of Greek forces from Anatolia (Gurun 1988, p. 383).

The first and second Battles of Inonu which took place in 1921 were the ones carried out with the newly established regular Turkish army. These battles were followed by the Sakarya Battle which took place in August 1921. After this battle the Turkish deportees 
on Malta were exchanged for British prisoners held in Anatolia. In the meantime the French evacuated Cilicia. The Italians had already withdrawn their forces by mid-1921. Powell. who was a former American consular officer in Syria, argues that from the beginning of 1920 on, the conflict between the Allies and the Turks had resolved itself into a conflict between the British and the Turks. France and Italy had supplied Turkey with arms and munitions for use against the British and Greeks. As he claims, "France not only tumed over to the Nationalists the stores of war material which she had collected in Cilicia, but provided them with aviation instructions. During the two years that followed there was a continuous flow of military stores into Turkey...so that the Nationalist armies were in certain respects tolerably well equipped when Mustapha Kemal launched his great offensive in the autumn of 1922" (Powell 1923, p. 91).

The final attack on Greeks which began in August 1922 ended in September when the Greeks were forced to withdraw their army from Anatolia. In November 1922 negotiations began between the Allies and the Turks at Lausanne. The Treaty of Lausanne, which was signed in July 1923, recognized Turkey as an independent nation. In this treaty there were no articles concerning either the Ottoman Greeks or the Armenians. During the Lausanne negotiations the League of Nations proposed a population exchange between the Greeks and the Turks. Adopted by both parties, the Greeks in Turkey were exchanged with the Turks in Greece in 1923.

The republic was proclaimed in October, 1923. Many reforms were carried on after the establishment of the Turkish state which initiated new forms of resistance and opposition 
to state policies. What follows next is a discussion of these developments under a separate heading.

\subsection{Realstance and Ropublican Turkoy (1923-1935)}

After the signing of the Lausanne Treaty the National Assembly proclaimed the republic in October, 1923. The Sultanate having been abolished in November, 1922. the next important step taken by the nationalist government was to abolish the Caliphate in March. 1924. The abolition of the Caliphate and many other reforms, such as the hat reform and the acceptance of the Latin alphabet, initiated new forms of resistance which I discuss in this section. The opposition movements active during this period were mostly religiously oriented. In addition. Kurdish claims for independence constituted another major form of opposition to the newly established Turkish state. There were also various other incidental resistance acts against the policies and reforms of the state.

The veil, fez, Arabic letters, and religious schools were all elements of Muslim identity that prevailed in Ottoman society. Although the 'fez' was itself an 'import', it did take root among the Muslims as to symbolize loyalty to Islam. In this context, the abolition of the Caliphate, secularization of education, hat reform, unveiling of women, and the adoption of the Latin alphabet can all be regarded as reforms attacking the religious sphere which had great control over the lives of individuals. Consequently those who resisted such reforms were mostly motivated by religious values and beliefs. They often saw Islam as the unifying force against the changes initiated by the Nationalists who, in a way, aimed at 
destroying old forms of Muslim unity. As Mardin argues, "these secularising reforms are linked by the underlying common denominator of the liberation of the individual from the collective constraints of the Muslim community" (1981, p. 213). In this context those movements of resistance which followed such westernizing policies generally aimed at preserving 'traditional' ways of life.

The first point to be discussed are these transformative developments towards establishing a modern nation-state based on the European model, and refer to the reactions and movements of resistance that followed these radical changes. At this point, following Berkes, it is important to note that the Westernizing and secularist reforms carried out by the Kemalist regime were not decided overnight, but were a consequence of the previous events which took place in earlier centuries (1957, p. 41). Many Westernizing reforms were carried out in earlier centuries by Ottoman sultans. However, the reforms of the Kemalist regime, for the first time in history, were based on building a modern nationstate along Western lines. As Mardin points out, the conception of the Turkish Republic as a nation-state was a new idea. In Mardin's words, "Mustafa Kemal took up a nonexistent, hypothetical entity, the Turkish nation, and breathed life into it...Neither the Turkish nation as the fountainhead of a 'general will' nor the Turkish nation as a source of national identity existed at the time he set out on this task" (1981, pp. 208-209). In this respect the process of Westemization was totally differed from the previous efforts, both in terms of its logic and in terms of its consequences. It was not a partial imitation of Western societies, but an effort to construct a totally new state and society. 
It is at this point that secularism appears as the most important step taken by the Kemalists in establishing the new' state. For as Berkes points out. "the problem of secularism even in the Christian West was not merely a problem of separation between the institutions of church and state, because the separation of the state from the church is only 'one' aspect of the process of secularization in a society. Equally important is the separation from religion of economic, social, and cultural institutions and of the types of mentality associated with them" (1957. p. 43). In view of this perspective I claim that Kemalist reforms aimed at liberating the individual and their social lives from the constraints of the religious domain.

\subsubsection{Abolition of the Callphate}

The Ottomans were the heirs to the Islamic Caliphate and the Ottoman sultan assumed the role of protector of the entire Muslim world (Mardin 1981, p. 193). Each sultan held both powers, the power to rule and the religious power of the Caliph as representative of all Muslims. In general, the union of religion and state was the most characteristic aspect of Ottoman society. In this system. "religion and society were fitted to each other in terms of the requirements of a particular form of political authority, of economic and social organization and of the concomitant ideological structure. The key to all was the principle of tradition. If the content of the tradition was supplied by the 'shariah', the form and force to be given to it were supplied by the state. Each needed the other" (Berkes 1957, p. 47). In this respect the abolition of the Caliphate was the most characteristic aspect of the Turkish Revolution, and was a very radical break from the Ottoman society. 
The Caliphate was abolished on these grounds. Yalman, in his memoirs, writes about a meeting Mustafa Kemal held with the editors of seven Turkish daily newspapers. The meeting was about the future of the caliphate and Mustafa Kemal wanted to know what this group thought about it. When Mustafa Kemal told them that the best solution was to abolish the caliphate altogether, the crowd was shocked. In Yalman's words.

We felt as though we had been struck by lightning. Our brains stopped functioning. Somebody dared to think and speak of the abolition of the thalifate! It was like telling the Irish that the Vatican was to be outlawed. What about sacred traditions, centuries old? What about the resentment of the whole of Islam, and of the people of Turkey? How would all those infuential religious dignitaries, 'hocas' (teachers) and 'imams' (prayer leaders and preachers), of thousands of mosques all over Turkey react to this revolutionary move? How could a young government just emerging from wars and revolts accept such far reaching risks and court the dangers of revolt? This man. Mustafa Kemal, had proved up to now that he had superior vision, but had he not suddenly gone mad?" (1956, p. 137).

The same day this group of journalists agreed to carry out a plan. Following the plan they attacked the government in their newspapers for not realizing the danger that the continuation of the Caliphate constituted to the unity and stability of the country. In Yalman's words, "we were to point out that the khalifate [Caliphate] was obsolete from the standpoint of a modem Turkey, that the prestige attributed to it was a myth, and that the victory of the Turkish nation would not be complete without a concerted assault on the theocratic influences which blocked progress. This plan was carried out in a marvellous spirit. We were astonished when we did not encounter the opposition and resistance anticipated" (1956. p. 141). Following this testing through the press the Caliphate was abolished, which was an attempt to cut Turkey's links with the past and with Islam. 
The abolition of the Caliphate was accompanied by other reforms. The office of 'Seyh-ulIslam' and the Ministry of 'Seriat' were abolished. In addition all religious schools (Medreses) were closed. Most important of all the Seriat Courts which administered the Holy Law were also abolished. These transformations marked a radical break from the Ottoman society. In the 1924 Constitution the article that stated that 'The religion of the Turkish State is Islam' was retained. Only in 1928 this clause was deleted from the constitution. and Turkey legally became a secular state.

There was no immediate opposition to the abolition of the Caliphate. However. soon after the abolition of the Caliphate, the 'Progressive Republican Party' was formed by the opponents of Mustafa Kemal (in November, 1924), which was a party with a religious outlook. This new party was strongly supported in Eastem Anatolia. the region where almost all Kurdish-Islamic revolts took place following the abolition of the Caliphate. In this respect recent forms of religious opposition movements were more organized and large-scale compared to the former forms of reactionary religious movements. For those against secularization were represented within the parliament to a certain extent.

\subsubsection{Rolligion and Seculariam}

The Turkish religious revolution was a very important step towards the establishment of secularism in an Islamic society. It was revolutionary because Turkey was the first among other Muslim societies to separate religious affairs from the sphere of state activities. Mardin emphasizes that, "in Turkey, laicism amounted to more than the official disestablishment of religion, since Muslims did not dispose of an autonomous religious 
institution such as the Catholic Church which could carry its religious functions independently of the state...In Turkey a limb of the state was torn out of its body when laicism became the state policy" (1981, p. 191). The process of secularization did not influence the everyday life of individual citizens since they were able to continue practising their daily religious rituals. As Yalman notes, "through well-planned and wellexecuted publicity, basically persuasive, one of the more radical and rapid reforms in social history found general acceptance as a matter of course, and public life continued without real shock" (1956, p. 143). However, religious movement stemming from the abolition of the Caliphate were not based on demands to practice private beliefs, but were political movements demanding a change in the system.

At a broader level, former religious leaders were left without much power compared to the Ottoman society. Since the Ottoman times conflict between the center and periphery had always been apparent at the level of two conflicting forms of Islam, orthodox Islam and heterodox Islam. This division within Islam has a significance for analyzing the movements of resistance experienced after the formation of the new state. For this reason I highlight some of the basic features of this division which had stimulated new tensions within the Turkish society.

The two forms of Islam, orthodox and heterodox, had been operating as two separate and conflicting world-views or realities. Whereas the first is the state-supported orthodox religion, the latter is folk-Islam which is a fonce shaped by more elusive forces and which operates at the grass roots level (Mardin 1989, p. 105). Local sect leaders and charismatic sheikhs are the leading figures in this second form of Islam. In addition to these two 
forms of Islam. the Muslim population is divided between the Sunni Muslims and Shite Muslims (known as Alevis in Turkey). Sunni Muslims constitute the majority in Turkey. and Sunni Islam is the accepted form of Islam by the state which had been imposed upon the masses. The Alevis, on the other hand, constituted the minority and they are considered as heretics.[29] Shiism was a subversive doctrine, and it had a history of affinity for charismatic leadership and the protection of minority groups of inferior status. It thus attracted the groups already alienated from the centre (Mardin 1977. p. 282). Alevi Muslims are recognized as distinctly different Muslims, and there is little intermarriage between Alevis and Sunnis which contributes to the continuation of this separation. Consequently, it should be emphasized that Islam is not a unitary religion as assumed by many. As Mardin points out.

That Islam has been conceptualized as unitary rather than segmental is probably due to the prevalence of a latent. Turkish folk-model' of Islam most prevalent among the 'Sunni' of exemplary piety. But this model has also influenced more detached observers among whom we may count Westernized intellectuals with no special sympathy or antagonism towards Islam. This model, which postulates the existence of one single form of Islam in Turkey is possibly the 'code' which has developed over centuries to counteract the real fragmentation of religion in this country. Only recently have some richer outlooks been brought to bear on religion. although, this time, it is from the vantage point of the varieties of Westem sociology (1977, p. 280).

Popular or mystical form of Islam, which is represented by dervish orders, had always attracted the local populations. Whenever official Islam failed to satisfy the religious needs of the local populations, they turned to the dervish orders (traditional Sufi brotherhoods). As Mardin argues, “a central Islamic tradition, which in its essentials showed great similarities, prevailed in cities throughout the Islamic world. But in the wider span of that world, as in many regions in the Otoman empire proper, this unity 
disappeared, and heterodox doctrines, charismatic leaders and cults with deep local roots and only an Islamic veneer became items to reckon with. This religious heterogeneity was a source of deep worry for Onoman statesmen" (1981. p. 193). All unorthodox dervish orders were attacked by official religious authorities during the Ottoman rule. However, brotherhoods continued to extend their influence over the local Muslims. These dervish orders, too, were not unitary. There were many divisions and conflicts among them. This became apparent during the War of Independence when many brotherhoods supported the Nationalists, while others supponed the army of the Caliphate.

The Shite form of Islam had been adopted in Iran by rulers who had been in conflict with the Ottomans. The Ottomans considered Outoman Shiites as a danger to their unity. Shiism became extremely influential in Anatolia over time and the Ottomans developed various policies to secure their unity and legitimacy since these religious splits had the potential of causing serious religious movements against the government. First, they tried to impose orthodox. Sunni Islam upon the Shiites. Secondly, dangerous heterodox groups were deported to the corners of the empire. Thirdly, they tried to build a religious elite under the control of the state. Thus the doctors of Istamic law (ulema) were transformed into officials. This last policy made the 'ulema' part of the policy-making groups (Mardin 1981, p. 193). While the 'ulema' became rich and powerful over time, dervish orders remained to represent large sections of the population where the dervishes had great influence and prestige among local populations (Lewis 1968, p. 406).

Lewis argues that the secularizing reforms of 1924 were directed against the ulema, not against the dervish orders. As he writes. "it soon became apparent that it was from the 
dervishes. not the ulema. that the most dangerous resistance to laicism would come. The ulema. long accustomed to wielding the authority of the state. were unpractised in opposing it. The dervishes were used to independence and opposition: they still enjoyed the confidence and loyalty of the common people" (1968. p. 409). Lewis, on these grounds, argues that it was under the influence of these dervish orders that the Kurdish tribes rebelled against the Ankara government after the establishment of the new state (1968, p. 409). Contrary to Lewis's position, although the centralist remnants of the Ottoman Empire was the first target, it can be argued that Mustafa Kemal was determined to attack all dervish orders since their practices contradicted 'modernity'. which was the programme of the Kemalists. All mystic onders (tariqas) were abolished by law after the Sheikh Sait Revolt of 1925, and "it is clear that what Ataturk had in mind was to disallow the influence of local charismatic leaders who were either notables with local political power or appeared as ignorant and cunning figures exploiting the lower classes. Turks would in future be ruled not by corrupt sheikhs but according to the way set out by science" (Mardin 1981, p. 216). I discuss non-Kurdish Islamic resistance in the context of hat reform, unveiling of women, and alphabet reform.

\subsubsection{Kurdish Revolts}

Although Turks and Kurds had fought togethe against the Armenians and the Greeks during the War of Independence, the Ankara government was determined to create a socially and politically homogeneous population within the borders of new Turkey. The Sheilch Sait Revolt, which took place in 1925, contributed to the development of such policies of homogenization. Thus the struggle between the Kurds and the Turkish 
government had evolved into a new stage by creating new axes of tension. Kurdish ethnic opposition became articulated to this new form of 'governing' by means of religious appeals, which resulted in numerous revolts in Eastern provinces of Anatolia. The Kurds now claimed independence in more organized ways in their fight against the Turkish central government.

Before discussing Kurdish movements of resistance that vecurred after the proclamation of the republic it is necessary to elaborate on one characteristic aspect of Kurdish revolts at a more general level.

The strict division among Sunni and Alevi (Shiite) Muslims, which caused hostile relations between Muslim Turks, also applies to Sunni Kurds and Alevi Kurds.[30] Moreover, regions are divided with regard to their own religious politics. For this reason all religiously oriented protests which took place in Anatolia remained at the local level and did not initiate any unified peasant movement. In this sense, Kurdish resistance movements. which were at the same time religious movements, resembled the millenarian movements experienced in Europe between the eleventh and the sixteenth centuries. As Cohn puts it, these millenarian movements were different from the usual revolts of peasants or artisans for they had local and limited aims (Cohn 1970, p. 15). Kurdish tribes, who are divided acconding to their religious orientations, were not able to organize mass peasant revolts due to their local aims. Moreover, "although Islam is a prevailing element in local culture. it is not the only source of cultural identity. Tribal and kinship ties. regional loyalties, educational and class differences provide the local people with altemative and complementary sources of identity and culture networks" (Yalcin- 
Heckmann 1991 A, p.117). As Mumcu reports. there were a considerable number of

Kurdish tribes supporting the new state while many were opposed to it (Muncu 1991. pp.

75-76). I elaborate on these divisions stemming from religious conflicts further with regard to the Sheikh Sait Revolt.

Van Bruinessen's extensive study on the Kurds supports the argument that Kurdish revolts were mainly millenarian movements.[31] As he claims.

Several of the early proto-nationalist rebellions of the late nineteenth and early twentieth centuries showed distinctly millenarian features. Typically led by shaikhs, they hoped for the establishment of a radically different society, expected to come about as a result of largely symbolic action. They were reactions against the penetration of Western influence and to the challenge to traditional values that this represented. Protest was couched in religious terms, and the participants acted in blind obedience to the shaikhs, whose charisma was apparently believed to make strategic considerations unnecessary (1992. p.250).[32]

The secularizing reforms of the republic provoked several mahdist rebellions led both by Turkish and Kurdish sheikhs. The Kurds, who were against Sunni Islam imposed upon them by the central govemment. resisted by means of heterodox religious values. After the abolition of the Caliphate they became articulated to the secular Turkish state with a new discourse of resistance. a form of resistance which was a mixture of nationalism and religion.

Heterodox Dervish orders, such as the organized popular mysticism of Nakshibendis. Qadiris (Kadiri), and Bektashis, always had been in conflict with the orthodox religion of the state and the Ulema in the Ottoman Empire (Ayata 1991, p. 224). The Kurds were largely believers in such mystic orders, and in this respect they were religiously opposed to the republican guvernment. The Nakshibendi order was popular among the Kurds, and 
the famous Sheikh Sait Revolt was led by .Nakshibendi Sheikhs. In this context, I highlight some of the characteristics aspects of Nakshibendi mysticism.

The Iraditional Nakshibendi order was a particularly orthodox, well integrated Sunni organization, and is still influential in Turkey today (Mardin 1977, p. 289). As van Bruinessen notes, the Nakshibendi order together with the rival Qadiri (Kadiri) order. "was the only organization that cut through all tribal boundaries and was independent of. even defiant of the state. It formed a network that spread across the whole of Kurdistan as well as the neighboring parts of the Ottoman Empire...As far as its organizational structure is concemed, the order resembles the mafia. There are hierarchical principles involved, but the entire organization is not well centralized: relatively independent regional centres exist and the extent of their influence fluctuates with the vicissitudes of the day" (1992, pp. 210-211). The ability to establish branches without the consent of the leader during the twentieth century became an organizational advantage for the Nakshibendi which contributed to their long-term success (Mardin 1991, p. 135). Due to this weak centralization many Nakshibendi Sheikhs were engaged in power struggles.

There are certain practices that characterise the Nakshibendi order. As Mardin notes,

The Naksibendi are usually described as a Sufi order, but this account does not fasten on their most characteristic internal spring. If Sufi means mystic. Islamic mysticism, whether ecstatic, spiritual, poetic or cosmic, whether induced by rules of mortification or framed by theosophical speculation, does not fit well with the sober, inwoven, inwrought, disciplined spiritual practices of this order, which also have had a major role to play in its viability. What in the case of the Protestant ethic seems to have worked for capitalism. in the case of the Naksibendi worked for the social mobilization of Muslims (1991, p. 123). 
From the sixteenth century onward the Nakshibendi elaborated ideological instruments which became focused on mobilization methods. However. as Mardin points out.

The success of the order was not simply an outcome of these organizational features. After all, its direct influence on followers was through the effectiveness of a discourse. This discourse was based on such elements of self-discipline as 'awareness in breathing' (hush dar dam). 'watching one's step' (nazar bar qadam). 'internal mystical journey' (safar dar watan), 'solitude in the crowd' (khalwat dar anjuman), 'recollection' (yad kard), 'restraining one's thoughts' (baz gard). 'watching one's thoughts' (nigah dasht). and 'concentrating upon God' (yad dasht) (1991, p. 135).

Mardin also claims that there was and is a Nakshibendi involvement in politics. The pattern of this involvement is not immediately obvious, and the mode of involvement has changed with time (1991, p. 123). The Nakshibendi had not questioned the integrity of the Ottoman Sultanic position which further contributed to their political success. For example. the Halidi branch of the Nakshibendi was influential in government circles in Istanbul, and "this was due to the Naksibendi support of the idea that the central powers. the bureaucrats in Istanbul, should refurbish the apparatus of state and rejuvenate Ottoman might in the face of Westem military and administrative superiority" (1991, p. 130).

These mystic orders (Nakshibendi and Qadiri) drew their followers from among the lower strata of society, and they were the only organizations open to the oppressed (van Bruinessen 1992, p. 212).[33] It is necessary to discuss the Nakshibendi order since it was the Nakshibendi sheikhs that played key roles in Kurdish nationalism. Sheikh Sait, who led the 1925 revolt, was also a Nakshibendi Sheikh and he mobilized his warriors from among the believers of this order by using the Nakshibendi network. Van Bruinessen gives two reasons for the rapid growth of the Nakshibendi order which 
overtook the role formerly played by the Qadiri order. First, the Nakshibandiya is a more efficient organization and open to autonomous growth compared to the Quadiri order. For, unlike the caliphs of Qadiri sheikhs, the Nakshibendi caliphs, over time. become sheikhs themselves and they too appointed new caliphs some of whom became sheikhs themselves. In addition the sons of Nakshibendi caliphs automatically become caliphs in their tum. This structural organization accounts for the rapid spread of Nakshibendi order among the Kurds.

Secondly some structural changes that took place during the early nineteenth century contributed to the expansion of this particular dervish order. Christian missionaries effected the local balance of power in Eastern Anatolia which accelerated the tensions between the Kurds and the Christian minorities. For the Kurds believed that European powers would ally with the Christian minorities against the Muslims. In addition, the reforms carried out by Mahmut II (1808-1839) who tried to establish centralization and direct rule, destroyed the existing local dynasties giving rise to severe struggles between the tribes to gain power. With these developments the sheikhs assumed the role of local political leaders to settle tribal conflicts and feuds that the government officials could not handle since they did not have sufficient authority and legitimacy. Lastly van Bruinessen argues that. sheikhs did not appeal to the most exploited low-class peasants to mobilize a following. On the contrary, all sheikhs were aristocratic, and they preferred to deal with tribal chieftains. For it was a more effective way to manipulate these chieftains in order to be able to manipulate and mobilize the entire tribe (van Bruinessen 1992, pp. 224-232). 
Dervish orders representing the form of Islam prevalent among ordinary Turkish people still constituted a threat to central authority as they had during the Ottoman rule. Moreover. due to the new roles of sheikhs as negotiators in tribal conflicts, the sheikhs now had more power among the population than ever before. They were capable of mobilizing the entire tribe since the tribe as a whole considers itself as the follower (murid) of a certain sheikh.[34] The sheikhs not only had political power but economic as well. They had many followers among different tribes who brought gifts in money and kind. In addition, together with aghas (landowners), merchants, and local government officials, the sheikhs had benefited from land registration reforms that took place in the second half of the nineteenth century. They became rich landowners. As van Bruinessen notes,

most shaikhs, even in Turkish Kurdistan where they suffered a severe blow when the orders were banned, belong to the landed elite and cultivate good relations with the local state apparatus, which enables them to continue exploiting the peasantry and in some cases even to usurp more villagers' lands. Aghas, shaikhs and the local or regional representatives of the state are often connected with each other through ties of mutual benefit and parallel interests, both political and economic. Fierce conficts between individual members of these three categories may occur. but the relations between the categories as such are symbiotic, each supporting and reinforcing the other's position (1992, p. 249).

Although it was some of these religious orders and sheikhs who actually supported the Nationalists during the Independence War, Mustafa Kemal was determined to unify Islam by suppressing such religious orders. For he thought that brotherhoods were capable of mobilizing the masses against the newly established secular Turkish state. Since the new state aimed to transform traditional bonds of religion it had good reasons to be threatened by any form of religious oppositional movement. In this respect the Sheikh Sait Revolt 
confirmed such a perspective, and provided the motives for the government to attack these sectarian forms of religion and to ban their orders.

I continue with Kurdish opposition movements, with special emphasis on the Sheikh Sait Revolt. A total of seventeen revolts occurred in Eastern Anatolia between 1924-1938. and except for one, all were Kurdish revolts. Before the Sheikh Sait Revolt broke out, a minor revolt known as the Nasturi Revolt occurred in 1924. This revolt began with an attack by the members of the Nasturi tribe on Turkish military officers, which was a common form of resistance among revolting Kurds. The Govemor of Hakkari was captured and three gendarme together with their commander were killed (Tuncay 1992, p. 111). The revolt, which was suppressed casily, can be considered as an incidental resistance act against state authority.

Here I discuss the Sheikh Sait Revolt in detail. This revolt was one of the important ones that took place after the establishment of the republic in 1923. It was a religious revolt as well as a political-nationalist movement.[35] The revolt broke out in the Dersim region of Eastern Anatolia and was led by a sheikh who was the chieftain of the local Nakshibendi dervishes. Sheikh Sait was a very wealthy man who owned vast herds of sheep, and had great influence over the powerful sheep-owning families in the neighbor.

Following the abolition of the Caliphate, Sheikh Sait revolted against the Ankara government aiming to bring back the Islamic Holy Law. Van Bruinessen claims that, the revolt was organized by a Kurdish political organization known as the 'Azadi' (Freedom) which was founded in 1923.[36] The 'Azadi' was not a Nakshibendi organ; it was a 
nationalist Kurdish organization, and it used Nakshibendi networks in their struggle for Kurdish independence since the Nakshibendi was able to mobilize its followers more effectively than the Kurdish nationalist organizations. As a result of this link between the 'Azadi' and the Nakshibendi order, the Sheikh Sait Revolt broke out in Eastem Anatolia. a region characterised by Nakshibendi networks.

The 'Azadi', different than the former ones (see end note 36), was formed by military men. Van Bruinessen writes that several Kurdish militia (Hamidiye) commanders were involved with the Azadi. He also writes that, in the army corps at Diyarbakir. almost fifty per cent of the officers as well as the rank-and-file were Kurds (1992. p. 283). Thus both Kurdish militia commanders and the Kurds in the Turkish regular army composed the 'experienced military men'. For example he writes that one of the central persons of Azadi, Khalid Bey, was a colonel in the regular army and he was much respected by tribal militia commanders. The party's headquarters were in Erzurum. In a congress held by the Azadi organization (in 1924) the Kurds decided to revolt as a means to attain their independence. Sheikh Sait was invited to the congress since he had great influence among the Zaza-speaking Kurdish tribes who had carried out this particular revolt (1992, p. 280).

At the beginning, the revolt looked like a minor local uprising which could be controlled easily. However, it turned out to be a serious one threatening the existence of the new regime. The rebels occupied many villages, captured Elazig, and surrounded Diyarbekir. Sheikh Sait's forces took control of government offices and imprisoned gendarmes. As Kinross describes the revolt. 
Sheikh Said and his followers swept through the Kurdish high-lands 'on the road to God', waving green flags and clutching Korans to their breasts, raiding banks and plundering shops and houses, calling in the name of the Almighty for all Turks to surrender. The preachers inflamed them with promises of heavenly rewards. Leaflets were distributed and scattered from the air, declaring that the Caliph demanded their sacrifice, that Islam was not Islam without a Caliphate. Let them restore the Holy Law, let them destroy this Government, which taught atheism in its schools and allowed its women tc go about naked (1956, p. 399).

Originally it was planned that all Kurdish tribes should join the rebellion. However, those who participated in the revolt were the poor. Zaza-speaking tribes, the followers of Sheikh Sait. Sheikh Sait also tried to convince the Khormek chieftains to join the other Kurdish tribes in the 'holy war' against the Ankara government. However, the Khormek (Alevis) did not join the revolt, and together with the Lolan tribe they fought the rebellion much more effectively than the gendarmerie and army (van Bruinessen 1992, p. 285). The Alevi tribes opposed the revolt because they had always been against the Sunni and antiShite ideology of the sheikhs and tribes that had participated in the revolt. Moreover. under the new secularist regime, the Alevis' rights were protected. What these incidents indicate is that while the Kurds were in revolt against the Ankara government, several tribes were fighting among themselves trying to settle past tribal conflicts and feuds.[37] When Mustafa Kemal ordered other tribes to join the suppression of the revolt many tribes did so. However, as van Bruinessen notes, many avoided real confrontation with the rebels, and those who actually did attack the rebels attacked only after they realized that the rebels were going to lose (1992. p.290).

It was during this revolt that the Law for the Maintenance of Public Order (Takrir-i Sukun) was passed by the Assembly. With this law the govemment attained wide powers 
to suppress any kind of rebellion or resistance. The Courts of Independence, which had extraordinary powers. were re-established to secure order in Turkey.

The Sheikh Sait Revolt is still hotly debated. According to one perspective, the Mosul question created tensions between the British and the Turks and this revolt is seen as organized and controlled by the British who favoured the establishment of an independent Kurdish state in Eastem Anatolia (e. g. Aybars 1988. p. 291: Kabacali 1991).[38] The other perspective argues that the Sheikh Sait Revolt was purely an Islamic reaction (e. g. Kinross 1965: Timur 1993, p. 67; Gologlu 1972, p. 127). Indeed this is claimed by Sheikh Sait himself. A third perspective sees this and the other revolts as a feudal reaction to the Kemalist Revolution which is characterized as a bourgeois revolution. There is yet another perspective defended by Tuncay and accepted by some Marxists. Tuncay opposes the first view which he sees as part of the official ideology. According to Tuncay, this revolt was a national Kurdish revolt with a religious outlook (1992, pp. 129-130). Following Tuncay, it can be argued that religion was used for political motives. Considering the past struggles between the Kurds and Turks, the abolition of the Caliphate provided the grounds for the Kurdis to react to the central government with new motives such as defending their existence by means of religious values. Van Bruinessen. 100. argues along this line. According to him, although the participants' religious and nationalist loyalties cannot be separated, the revolt was a nationalist revolt, and made use of the sheikh's charismatic power. As he writes,

a general uprising in all of Kurdistan and the proclamation of a Kurdish government were apparently deemed sufficient for the establishment of an independent state. It was known that the Turkish camp was divided internally, and 
that there was a strong current of conservative, in part religiously inspired. opposition to Mustafa Kemal. It would therefore be doubly advantageous to give the coming revolt a religious appearance as well. In the first place, many Kurds who would not otherwise join, would do so for religious reasons, while the government and the Grand National Assembly would not be a single monolithic bloc in opposition to the rising (1992, p. 281).

The Sheikh Sait revolt did not initiate further movements of resistance in other regions. It remained a local revolt. Kinross argues that. Sheikh Sait had not been wholly successful in mobilizing the neighboring tribes. For he had chosen to emphasize religion above that of Kurdish independence. The neighboring tribes were disinclined to accept the authority of a Sheikh who was a Naksibendi dervish. Kinross also argues that the movement failed because Sheikh Sait was not able to capture Diyarbekir, which was thought to be the capital of any Kurdish state in the future (1965, p. 401). According to van Bruinessen. the area of Diyarbekir was inhabited by non-tribal Kurds, who were tenants, sharecroppers or labourers, and these poor peasants did not participate in the revolt. The revolt was not appealing to them because. "the peasantry of the Diyarbakir plain thus had neither the economic independence which makes rebellion a feasible thing nor, most probably. the motivation. The revolt was not directed against their exploiters, but against a government that promised to curtail the power of these exploiters" (van Bruinessen 1992. p. 294).[39]

Although the Sheikh Sait revolt was a local nationalist revolt motivated by religious beliefs, its consequences for the formation of the new regime were important. In response. the government developed more strict policies to reform Islam. After the suppression of the revolt. Sheikh Said and forty seven other people were sentenced to death and hanged after being judged by the Eastern Court of Independence (Mumcu1991. 
p. 156). Following these executions, all fanatical dervish (mystic) orders (tarikats) were attacked and outlawed. and, as a result. Turkish Islam became more standardized. [ +0]

In addition to these developments. the revolt forced the government to take much more repressive measures against those who expressed their 'reactions' to the newly established state policies. Both the press and opposition party - the Progressive Republican Party were suppressed. In other words all forms of opposition were forbidden.

Several other Kurdish revolts followed the Sheikh Sait Revolt. However, very limited information exists about these revolts. [41] One of these revolts was the Nehri Revolt which took place in 1925 . This revolt, similar to Nasturi Revolt, began with attacks on regular army troops. It was led by Kurdish sheikhs and agas, and the revolt was suppressed without much difficulty (Kabacali 1991, pp. 45-48). Five other revolts took place between late 1925 and during 1926, which were Hazo, Haco, Sason, first Agri (Ararat), and Kocusagi revolts. In all these revolts the target was to attack Turkish army troops and military officials. For example the Kurds of Sason had never accepted rule by the Ottoman government. They had always refused to enrol in the army or to pay taxes. They participated in the Sheikh Sait Revolt and rebelled several times during the 1930s. In all incidents they attacked Turkish military officers and the gendarmerie forces (Kabacali 1991, p. 54). As Kabacali reports from British sources, the first Agri Revolt was a reaction to the deportation of some Kurdish families from the area to Ankara and West Anatolia (1991, p. 57). There were several other minor rebellions in 1926, some of which were motivated by the acceptance of the Hat Law (Kabacali 1991, p. 52). 
The revolts continued after 1926. The motivations behind these revolts were more or less similar. Most of the Kurds were against the Ankara government and they refused obedience to its policies whenever possible. For example, the Mutki Revolt, which took place in 1927, was a reaction to government's decision to deport the inhabitants of thirty five villages in the Mutki area. Eight tribes revolted against such a decision (Kabacali 1991. p. 63). In general, it can be argued that most Kurdish resistance movements were in response to state policies that aimed at assimilating them. As an indication of this opposition to the power of the state they attacked Turkish military officers present in the Kurdish areas, and invaded local government buildings in some instances. Many Kurdish families - in the years of 1925, 1927. 1935, 1960 - were forced to migrate to Western Anatolia by law (Mumcu 1991, p. 181, 238: Tuncay 1992, pp. 173-175). These measures were serious threats to their existence. According to van Bruinessen, the Agri (Ararat) Revolt of 1929-1930, may be seen as the direct continuation of Shaikh Sait's revolt. Some of the members of the Azadi organization who fled to Syria after the suppression of the Sheikh Sait Revolt formed a new nationalist organization (in 1927) known as 'Khoybun' which played some part in the Agri rebellion of 1929-1930 (1992, p. 265, 279). The Agri Revolt was supported by several smaller uprisings in different parts of Eastern Anatolia.[42]

After the Kurdish revolts in 1925 and 1928-31, the securing of Turkish territorial integrity became the a major task for government officials. As van Bruinessen notes,

many aghas and shaikhs were executed, put to flight or sent into exile; numerous tribesmen were deported to other parts of the country. Gendarmerie posts and schools brought the state closer to the tribesmen and taught them that they were not 
Kurds anymore but Turkish citizens. Everything that recalled a separate Ku-dish identity was to be abolished: language, dress, names and even the tribes

themselves. The government did away with all forms of indirect rule. and largely. though not completely. eliminated the intermediary positions of tribal chieftains. All shaikhs were persecuted and lost their practical political roles. In many areas this resulted in a definite increase of feuds and other conflicts" (1992. p. 191).

Following 1935, many Kurdish revolts broke out in Dersim region. in Eastern Anatclia.

The most important of these revolts. the Dersim Revolt, occurred in 1937-1938.

According to Tuncay, the greatest suppression against the Kurds occurred during these years (1992. p. 128). Besides all these revolts that broke out in Eastern Anatolia. one major revolt oceurred in Western Anatolia in 1930. This revolt is known as the Menemen Revolt, and it was organized by the Sheriatists. It was one of the large-scale revolts that was not a Kurdish movement but a religiously oriented movement. As Mardin notes, this revolt was a Nakshibendi outbreak. and "in a provincial town close to Izmir, a shadowy Naksibendi figure called Muslims to rally around the green flag and destroy the impious republican regime" (1991. p. 122). Although the revolt was led by a few people who killed a military officer in a brutal way, its impact was significant since a large number of the local populatio iook part in it. It was suppressed immediately and twenty eight people were hung after being tried before the Military Court (Gologlu 1972, p. 308).

The Kurds mostly refer to language and religion first as constituting their ethnic identity. There are various religious and linguistic groups among the Kurds. For example, Zaya speakers consider themselves, and are considered by the Kurmangi speakers, to be Kurds. Many Alevis, who speak Zaza or Kurmangi dialects, consider themselves to be Kurds as well. However, many Shafi'i Kurds refuse to consider Alevis and Yezidis (a non-Muslim sect living among the Sunni Kurds) as Kurds. There is extremely rare intermarriage 
between these religious groups, much rarer than between Turkish and Kurdish Alevis or even Turkish and Kurdish Sunnis (van Bruinessen 1989. pp. 613-614). In van Bruinessen's words,

It might, in fact. be more apt to consider the Kurds not as one. but as a set of ethnic groups (for instance. Sunni. Alevi. Yezidi). although even then the definition of boundaries would not be easy. The Kurdish rebellions of the early years of the Republic showed how little unity there was: Seyh Said's [Sheikh Said] rebellion (1925) remained largely restricted to the Zaza speaking tribes along the Murad Suyu. and in the Dersim revolt of 1937 only Alevis (both Kurmangi and Zaza speaking) participated. Nationalist leaders tried in vain to exhort others to join in (1989. p. 614).

The participants in the Kurdish revolts after the abolition of the Caliphate made use of religion to mobilize tribal support. However, these rebellions were nationalistic movements as well. In all cases the rebels proved that they were against the Turkish state since they often attacked government officers. [43] With regard to the Sheikh Sait Revolt. van Bruinessen argues that, "the way the revolt broke out and immediately spread suggests that a strong anti-Turkish or anti-government feeling motivated the masses, at least in the central area of the rebellion. The participants' zeal received additional fuel from the religious justification given to their action" (1992, pp. 298-299). This observation holds for other Kurdish revolts where the rebels attacked state representatives and refused to accept their authority. I find van Bruines_en's comment on nationalism very useful.

This [Kurdish] nationalism was based on quite 'traditional' motivations, and took the form of 'traditional' rebellion against state authority. The Ararat Revolt started with the Jelali tribe's refusal to accept external authority - any external authority. The guerilla bands followed the tradition of social banditry -- a phenomenon endemic in Kurdistan. just like everywhere else where the norms of society conflict with the laws of the state. These 'traditional' motivating forces have certainly also 
played their parts in the nationalism of the participants in Shaikh Said's revilt... The borderline between social banditry and politically motivated guerrilla wartare is difficult to draw. The same may be said of the boundary between 'traditional' resentment of government encroachments and nationalist sentiment. Kurdish nationalism in this century has always remained in the indefinable in-between, and still largely finds itself near the vague borderline (1992. p. 299).

The reforms which followed the Sheikh Sait Revolt were intended to complete the priness of secularization. The aim was to introduce new 'world views' and transtion the 'identities' of the ordinary people. In this respect. the reforms carried oul were highly symbolic. The reforms regarding clothing were particularly important for Turkey in becoming part of Western civilization. In this respect the reforms carried out covered the transformation of the personal domain as well. As Mardin argues. "these secularising reforms are linked by the underlying common denominator of the liberation of the individual from the collective constraints of the Muslim community" (1981, p. 21,3). In this respect, movements of resistance that followed these reforms were attacks against the progress of Westemization. and the resisters made use of religious values in mobilizing their followers.

\subsubsection{Unification of education in 1924}

One of the first steps taken towards secularizing the Turkish society was the law concerning the 'Unification of Education' which passed the Assembly in 1924. This law had important consequences. First, all education was secularised by cutting the links between formal education and traditional religious education. In the new system of education religious clergy had no role or influence at all. In addition, a unified education controlled by the state was thought of as a means to attain cultural and political 
homogeneity in Turkish society by undermining the influence of divergent religious and rocial beliefs. In a sense. 'local' and 'restricted' world views were to be transformed into Westerm scientific 'rationalism' which was assumed to bring cultural and political unity on new grounds.

Second. with this law equal chances for education were given to women. Women. for the first time in Turkish history, were formally freed from the restrictions placed upon them. This law enabled many women to recrive education and to enter professional life. As Mardin comments, "Turkey today has an enviable proportion of its professional cadres filled by women. The 'lifting of the veil', which was never placed into a statute, followed from this development" (1981 p. 216). Women gained more from further secularizing reforms which I will discuss below with regard to the unveiling of women. However. many agree that these reforms regarding the status of women ended up with a 'statesponsored' feminism, and did not bring about the freedom Western women had. As Kandiyoti argues. "Women's emancipation under Kemalism was part of a broader political project of nation-building and secularisation...However, the authoritarian nature of the single-party state and its attempt to harness the 'new woman' to the creation and reproduction of a uniform citizenry aborted the possibility for autonomous women's movements"' (1989, p. 43).

\subsubsection{The Hat Law in 1925}

A symbolic revolution which prohibited the wearing of the 'fez', a headgear that represented devotion to religion, was another step taken towards building a modern 
Turkish society. The fez had been the symbol of Islam for decades. $[+4]$ As Yalman writes. "no Muslim. and no man of any religion in government service. Would have dared to wear a hat in Turkey. though he would do so as a matter of course when he left the country. If a Muslim Turk had worn a hat in old Turkey, public opinion would have taken it as an open divorce from both religious and national bonds, and would have resented it bitterly" (1956, p. 174). Lewis provides an explanation for such a strong attachment to the fez. In his words,

Dress, and especially headgear, was the visible and outward token by which a Muslim, indicated his allegiance to the community of Islam and his rejection of others. During the past century modemization and reform had made great inroads into Muslim exclusiveness in matters of dress, and had created a new social gulf between the Westernized and the un-Westernized -the former comprising the male and secular elements of the ruling 'elite', the latter the rest of the population. But even among the immaculately trousered and jacketed dandies of the capital, one bad $z=$ of distinctness had remained -the fez. This headgear...had becorre the last symbol of Muslim identification (1968, p. 267).

Mardin writes about this gap between the elites and the ordinary people and analyses how it effected the building of the Turkish nation-state. He looks at the smallest unit of the community in the Ottoman Empire, which was the 'mahalle' or city quarter. The 'mahalle' reftected the normal life of an average Ottoman citizen, where folk control was the dominant form of control over the lives of individuals. In Mardin's view, Mustafa Kemal was determined to replace these personalistic ties that were prevalent in the 'mahalle' by a system of regulations that provided freedom and individual responsibility. For, "'Mahalle' virtues were linked to the preservation of small groups. There was no use for them in the building of the nation-state. Religious morality was replaced by intellectual and military disciplines" (1981, p. 214). On such grounds the traditional dress characteristic of the 
'mahalle', which symbolized the folk culture. was also rejected. Mardin refers to a story

written by Yakup Kadri. A westemised Turk is beaten up in a 'mahalle' because he wears a hat.

In this stagnant air, none of the atoms of which is moved by a melodious sound, in these squares, none of which is adomed by a figure, in these streets, the dust and the mud of which we daily brave, in the face of these people whose ears are deaf to any pleasantness, whose eyes are blind to any beauty, who squat at night in coffee houses with their coloured printed nightgowns listening to the tube of a gramophone vomit belly-dance tunes, I find the seeds of their sickness (in Mardin 1981, p. 215).

Mustafa Kemal aimed at transforming folk culture, for civilization was equated with Westem civilization and dress was the most visible sign of the civilization one belonged

to.

Ataturk first launched his plan to eliminate the 'fez' in Kastamonu, a town nearby Ankara with a reputation of being the most conservative community in Turkey.[45] Kinross describes one of Mustafa Kemal's first appearances wearing a hat on his way to Kastamonu,

In one village an artist had drawn on a wall an imaginative portrait of the Gazi, the slayer of infidels, as a formidable warrior with sweeping moustaches and a sword seven feet long. The villagers had spread carpets on the streets for him to walk on. One of them, a young student, recalled the scene years later: 'When the President walked slowly down the street, greeting the crowds, there was not a sound. The clean-shaven Gazi was wearing a white, European-style summer suit, a sports shirt open at the neck, and a Panama hat. The few officials applauded frantically, urging on those near them, but a flutter of hand-clapping was all they would muster, so great had been the shock.' For the conqueror was wearing the costume of the infidel (1965, p. 414). 
Mustafa Kemal arranged a meeting with the reactionaries of the town when he came to Kastamonu, and convinced them to wear the hats which he brought along with him as presents. I quote from Yalman with regard to the impact of his trip to Kastamonu.

When a group of pious conservatives led by Ataturk, all wearing hats. took a stroll through the main street of the town, people could not believe their eyes. Such was the case with the entire population in Turkey when they read an Anatolian News Agency dispatch in their papers the next day, saying that the conservative men of Kastamonu had accepted the hats given to them by Ataturk and had begun to wear them as more practical headgear. In all communities the radicals started to wear hats that very day. Others followed. Then a law was passed forbidding the wearing of the fez. Here and there the law met silent resistance, but there was no open manifestation of it. A reform thought impossible had taken place simply and smoothly (1956, p. 175).

The first step taken was to ban the wearing of religious vestments by persons not holding religious office. In addition, all civil servants were requested to wear the Western suit and hat while on duty. After these measures were taken, the wearing of the fez became a criminal offense when a bill passed the Assembly shortly after Mustafa Kemal's Kastamonu visit. Every man in Turkey was required to wear a hat in accordance with the new law. Although the reform was accepted more smoothly than expected, there were not only numerous acts of resistance against it, but also widespread riots in the East. As Kinross writes, these riots "were inflamed by placards in the name of religion on the walls of public buildings, which led to mass demonstrations beneath the green fiag of Islam. They had been anticipated by the government, who sent Tribunals of Independence in advance to the danger spots. They were suppressed by nuthless means" (1965, p. 416). As an example, Kabacali refers to an incident where Yakup Agha and his sons protested against the wearing of the hat, and initiated a rebellion among two Kurdish tribes in 1925 (1991, p. 50). 
In Adivar's view, among later measures taken to Westernize Turkey, the hat reform was the most seriously opposed reform in the country. Opposition to the hat law was labelled reactionary, and "the Islamic reactionaries, the liberals, the people who understood the spirit of the West were all opposed to it for different reasons" (1929. p. 31).

The Law for the Maintenance of Order provided the legitimate grounds for suppressing such resistance movements. Mustafa Kemal abolished the fez while this law was still in force. Many believe that these secularizing reforms, in the absence of such a law, would have created much more tension and strong reaction among the people. Adivar, who had joined the Nationalists during the War of Independence, argues that the regime of 1925 to 1929 in Turkey was a dictatorial regime, and that the reforms were carried out by terrorist methods (1929, p. 29). In her opinion, with the introduction of these Westernizing reforms, the continuity of Turkish culture had been suddenly broken. Adivar's reaction to Kemalist reforms indicates the fact that some of the reforms were not welcomed even by some prominent figures who were largely exposed to Western culture.

Aybars looks at those acts of resistance against the hat law within the context of the activities of the Courts of Independence. I summarize some of these reactions to provide a picture of the conditions in those days in Turkey.

Reactionary movements occurred in Erzurum and Maras. Since the hat symbolized Western people, the reactionaries in Erzurum started a movement howling "we do not want infidel (gaver) state officers". The movement was suppressed immediately, and Marshal Law was declared in the city for a month. Three people were sentenced to death 
while two were sentenced to imprisonment for ten years. There were also numerous acts of resistance in central Anatolian cities, such as Kayseri. Sivas, and Malatya. These movements were led by religious men, and those involved in the movenents put on turbans (sarik) to protest the hat reform. One of the reactionaries in Kayseri was a member of the Nakshibendi order. In addition manifestos insulting the government were hung on walls (Aybars 1988, pp. 406-407).

Other acts took place in the Black Sea Coast of Anatolia, such as in Rize and Giresun. Eight people were hanged and fifty-five people were sentenced to imprisonment in Rize because they were involved in the movement against the hat reform. The revolt was led by religious leaders who planned to loot Rize. The movement was supported by a group of armed bandits from nearby mountains but when the peasants refused to take part in this movement the rebels failed to carry out their plans (Aybars 1988, p. 411). The Courts of Independence had the authority to carry out executions without approval from the Assembly. This provided the Courts with unlimited power. The Ankara Court of Independence moved from one area to another and, during its travels, made orders to the people :o obtain their hats as soon as possible. When the judges of the Court arrived to Trabzon, they saw that almost everyone was already wearing hats (Aybars 1988, p. 409). They may have been due to their fear of conviction. However, in the meantime many rebels were convicted and sent to Ankara for trial. In general, these repressive measures taken by the state had prevented the further spread of such resistance movements.

Following these developments, Mustafa Kemal's opponents joined hands in the parliament. In 1926 a group of people who had opposed the abolition of the Caliphate 
attempted to assassinate Mustafa Kemal. This incident triggered a more widespread attack against his political opponents. The leading members of the former Progressive Republican Party, which had been outlawed after the Sheikh Sait Revolt, were accused with playing some role in this conspiracy. While many were acquitted others were executed by the Courts of Independence. According to Aybars, the period between 1925 1927 was very important in terms of the establishment of state authority, and the Courts of Independence played a major role during this transformative period. In 1927 these special courts were abolished (Aybars 1988, p. 481, 483).

\subsubsection{The Unvelling of Women}

The women for centuries had been totally excluded from public life. They had no rights at all. In public places, such as the trams and boats. women had to sit apart form men often in areas divided by a curtain. However, in certain parts of Anatolia women had more freedom. They worked in the fields for economic reasons and they could appear unveiled before men who were not strangers (Kinross 1965, p. 418). The leaders of the Young Turk period had carried out many reforms to improve the status of women. They opened the doors of middle and secondary schools, and later the universities, to female students. Adivar notes that a considerable number of women were sent to Europe, especially to Germany, for further education (1929, p. 32). Berkes writes that, during this period women writers began to defend the rights of women, and demanded equality as the prerequisite for modem family life. After 1908 women began to appear unveiled together with men, which initiated opposition from religious groups. As Berkes writes, "women in 
the towns were still entirely behind the veil while the majority of Turkish women. the peasants, had never been veiled or secluded" (1964. p. 386).

The passing of a Family Law during the Young Turk era (in 1916) was another significant step. With this law secular marriage was introduced. One other significant event was the entry of Turkish women into the economic field during the war period. They replaced men in many jobs and received the same salaries and wages as did men (Adivar 1929. p. 32: Berkes 1964, p. 387).

With regard to the clothing of women no laws were enacted. When such a law was proposed to Mustafa Kemal, he replied "you can't catch me doing that. When religious prejudice and men's jealousy over their women's faces being seen in public are coupled in this problem, it becomes most difficult to cope with. No legislation about veils! There is a natural law which will take care of it more easily than any written law. It is called 'fashion"' (Yalman 1956, p. 175). Consequently, the veil was never forbidden by law. However, those in government services were obliged to be unveiled while at work in offices.

Many women took off their veils and begun wearing modern dress. Baykan notes that. "in some municipalities, there were orders against women's traditional clothing. It is a common practice to cite incidences where soldiers would forcibly remove the veils of women, although there is no evidence to the extent of these happenings" (1990, p.142). In general the process of unveiling did not come about without resistance. There was both public encouragement for taking off the veil, and public pressure over the ones who did 
so. For example, Kinross refers to an incident where a deputy was seen one day with his wife unveiled in the street which caused much gossip in the Assembly (1965, p. 388). Although resistance to veiling generally took place silently, in some parts of Anatolia there were more open attacks against the unveiling of women.

In order to complete the process of transforming the traditional family life the Swiss Code, with some modifications, was accepted in February 1926. This was a major attack on the traditional functions of religion. As Lewis notes.

This was the first time that a reformer had dared to invade the intimacies of family and religious life, the inviolate preserve of the doctors of the Holy Law - and to do so, not by stealth. but by head-on attack. The God-given 'Seriat' was repealed by the Assembly, and its rules declared null and void, superseded by the new Turkish civil code. Polygamy, repudiation - all the ancient bars to the freedom and dignity of women - were abolished. In their place came civil marriage and divorce, with equal rights for both parties. Most shocking of all, to Muslim opinion, the marriage of a Muslim woman to a non-Muslim man became legally possible. and all adults were given the legal right to change their religion at will (1968, pp. 272273).

In the following years other developments providing more rights to the women followed.

In 1930 women were given the right to vote and stand for election in local contests.[46]

In 1934 they attained full political rights and duties with the passing of the law which gave the women the right to vote and stand for election in national elections. However, as Lewis writes, "even though the law gave them new and extensive rights, there were few village women who dared - or cared - to assert them against their husbands, fathers, and brothers. Even in the provincial towns, though polygamy disappeared, the women of the un-Westernized classes for a long time enjoyed very little real improvement in their status" (1968, p. 273). 


\subsubsection{Reform of the Alphabot in 1928}

Another reform which took place was the replacement of Arabic letters with the Latin alphabet. which symbolically was another break with the past. The change of alphabet was seen as necessary for two reasons. First. as a means of becoming part of modem societies since the Arabic script symbolized commitment to Muslim community. In this respect it was the last symbol of Muslim identity and it had to be removed if the process of Westernization was to be completed. Secondly, the Latin alphabet was adopted to cope with the problem of widespread illiteracy which was believed to be caused by the use of Arabic alphabet.[47]

Abandoning the Arabic alphabet was first proposed in 1923, but was rejected. By 1927 Mustafa Kemal gained enough power against his religious and political opponents and was able to take this last important step. As Lewis argues, at that time the Soviet authorities had adopted the Latin alphabet in place of the Arabic for the Turkic languages of the USSR, which gave the incentive to the Turkish government to carry out the language reform (1968, p. 277).

Preparations for the new alphabet was completed over a very shon time period. and public use of Arabic alphabet for the Turkish language was prohibited by law in 1928. As Yalman writes, "the entire country became a school to teach the new alphabet. Evening classes were compulsory for men up to sixty and women up to fifty years old. Ataturk was one of the teachers. From partly Arabic and party Latin, the newspapers went, in a few months, to entirely Latin characters. Circulation fell; the government had to subsidize some papers so that they might survive. The clever papers used many pictures and the 
new characters in very large type for some time. Then circulation began to rise and soon passed the old sales limits of papers in Arabic letters" (1956, p. 176).

The adoption of the Latin alphabet was not welcomed by all 'Westernized' intellectuals. For example. Adivar represents one of those who had reservations about these sudden changes. She expresses her views as follows.

We can conceive of modem civilization as an entirety. That is to say, we cannot put on Western civilization as a whole the label English. or French. or Italian. Therefore, even a nation that is a late-comer to this civilization is not simply their follower. but is also part of Western civilization. Total and slavish imitation of a model is the very opposite of the spirit of Western civilization. This point needs special attention irom late-comers to this civilization (in Lewis 1968. p. 279).

Adivar writes that those who favoured the Latin alphabet faced serious opposition. She groups the arguments against the adoption of the Latin alphabet into three. First, there were those who argued that the new alphabet would end Islamic and Turkish unity. Second, because the Koran was written in Arabic, Turkish children would have to leam the Arabic letters in order to read the Koran. Third, with the adoption of the new letters. the Ottoman Turks would be cut off from their past culture entirely. Adivar points out that arguments against the adoption of the new alphabet were basically political and cultural. and that there had been no serious opposition from the practical standpoint (1929. pp. 4041).[48]

Although the adoption of the Latin alphabet was seen as part of the Westernizing project it was also regarded as a necessary step in the process of strengthening Turkish national identity since it symbolically separated the Turks not only from the global Muslim community but also from the Arab world. After the Turks adopted Islam. Arabic and 
Persian languages that were foreign to the lower classes began to dominate among the ruling groups which gave rise to two separate languages, that of the Ottoman nobility and the local populations of the periphery (Mardin 1973.p. 173: Ucok 1979. pp. 824-825). The existence of these two languages fostered the development of two separate cultures. The adoption of the Latin alphabet, accompanied by the attempts to purify Turkish language by abandoning the use of Persian and Arabic words. contributed to the development of a Turkish national identity.

\subsubsection{Conclusion}

In this chapter I have discussed both phases of the state-building process in Turkey under separate headings. The dynamics of struggle during the second phase (1923-1930) differs from the dynamics of the first phase (1919-1923) which was at the same time a period of national liberation war against foreign invasion. The groups or actors involved in the process of state-building were different in the two periods. During the War of Independence Christian minorities, some ethnic groups such as the Circassians, and those supporting the Ottoman government were all involved in the state-building process, and they opposed the Ankara govemment for reasons of their own. Many other ethnic groups. however, such as the Kurds and the Lazes supported the Nationalists in Ankara. In addition social bandits and military deserters constituted another group of 'actors' who integrated themselves into this process either by joining the Nationalists or by resisting them in every possible way. Religious leaders and tribal chiefs (or landlords), too, were involved in this process where many supported the Nationalists. 
After World War I ended and the republic was proclaimed Christian minorities and some ethnic minorities, such as the Circassians. were ro longer part of the struggle for building a new state. In addition social banditry and military desertion ceased to exist as influential forms of resistance. After 1923 some of the former actors. such as the Kurds or religious groups established new links with those involved in the making of the state. While formerly they were supportive of the Nationalists. they now opposed the policies that took place after the ending of World War I.

The development of a Kurdish national movement, although initiated by the abolition of the Caliphate. can be considered as partly autonomous from other incidental resistance acts experienced during the same period. The ethnic tensions within the Onoman Empire had always prevented the local population's identification with the central state. The Kurds were able to protect their ethnic identity against the Ottomans. However, with the establishm.:nt of the new Turkish state the Kurds became exposed to a force determined to assimilate them. As van Bruinessen points out. missionary activity and fears of Christian domination made the Kurds stress their Muslim identity (1992, p. 233). The new Turkish state, which attacked not only Kurdish Muslim identity, but their ethnic identity as well. contributed to the Kurdish nationalist movement. Kurdish nationalism still remains a problem for the Turkish state.

Mardin sees the tension between the 'center' and the 'periphery' in the Ottoman society as a key to understanding Turkish politics (Mardin 1973). The culture of the 'Palace' and the culture of the 'provinces' were two forms of culture which remained wide apart. In general, it can be argued that the Ottoman modernization movement (the Tanzimat) failed 
to reduce the distance between the two cultures. As Mardin notes. the difference between these two cultures was basically a difference between French culture and Islamic culture (1969. p. 270. 274). The building of the Turkish nation-state did not result in a culturally and politically uniform society. Instead there has been a coexistence of two world-1 iews. life styles. and political and ideological structures that defined themselves as either 'traditional ' or as 'modern' (Baykan 1990. p. 137).

In this context it can be argued that the Westernizing and secularizing reforms of the Kemalist regime did not contribute much to reducing the gap between these two separatc cultures. For example. the introduction of the hat and the Latin alphabet were cotally Western measures in the eyes of some local populations representing the culture of the dominant ruling groups. Considering the growing Islamic reaction to the Kemalist regime in Turkey today, it can be argued that republican secularism had indeed deepened the gap between the center and the provinces. and contributed to the tension between 'modernity' and 'tradition'. In this espect state-building in Turkey which was a process of forced homogenization can be conceptualized as an incomplete attempt.

Those resisting the modemizing Kemalist reforms were protecting their 'traditions' against the influence of the West. a tradition which has been deeply rooted in Islam. However, it would be a mistake to group every reaction under the category of 'religiously oriented reaction'. The clash between 'traditional' and 'modem' forms of life is not specific to the building of the Turkish state. As Baykan puts it, "at any given time, in any society. there are various conflicts between alternative power structures. Today, given these conflicts and resulting forces for social change, one side of the conflict identifies itself as the one 
that advocates historical continuity. It stands to represent the 'traditional' society and oppeses a 'modern' one which may be regarded as either corrupt. alienating, imperialist. Western. or as any uther symbol for the 'other"' (1990. pp. 138-139).

In general, each phase of the state-building process provoked differert forms of resistance and opposition frnm various sections of the population. In Chapter Five I analyze the link between the state and these various forms of resistance discussed in this chapter. I also discuss the impact and consequences of resistance movements for the newly established Turkish state. 


\section{CHAPTER NOTES}

[1] Morgenthau, who was the American Ambassador to Istanbul between 191.3-1916, writes that, "As tior Constantinople, the populace there and the best elements among the Turks, far from opposing the arrival of the Aliied fleet. would have welcomed it with joy. The Turks themselves were pray ing that the British and French would take their city, for this would relieve them of the controlling gang. emancipate them from the hated Germans, bring about peace, and end their misenes" (1918. pp. 227. 228).

(2) The areas most troubled with military desertion were Kastamonu. Amasya. Konya. Eskıschir. and Ankara (Aybars 1988. p. 148).

[3] According to Selek and Avcioglu there were more than 300.000 military deserters by the end of Wirld War I. A great majority of these military deserters were engaged in brigandage throughout Anatulia (Selet 1963, pp. 18-19; Avcioglu 1986. pp. 958-959). As Avciogiu notes there were 43,(0X) soldiers in the army in May 1919 (1986, p. 969). Steinhaus also claims that there were more military deserters than the actual number of soldiers serving in the army in 1918 (1974, p. 80).

[4] Amasya. Aydin. and Kayseri were other places which had no safety due to robbery and attacks by the brigands (Aybars 1988, p. 7).

[5] Selek argues that although the National Forces were composed of armed peasant bands they were mit really related to the peasantry. For the National Forces often badly treated the local people. They were very threatening because they were involved in robbery, plunder, pillage, and usurpation (1963, p. 104; Mehmet Arif 1987, p. 54). According to Selek, partly because of their fear of the Natuonal Forces, and partly because they wanted to remain uninvolved in a new war, the peasants never really felt attached to the National Forces (1963, p 104).

[6] The term 'efe' had originated from Aydin (a city in the Aegean region) and the area surrounding Aydin. Noyan claims that its original meaning is assumed to be 'brother' (aba-kardes). According (1) 
Noyan, the term 'efe' symbolized honesty, friendship, loyalty to the country, and self-sacrifice ( 1982. p. 8). 'Today 'efe' stull is a name given to boys.

17] Although Ozturk's study focuses on a specific region in the eighteenth century. I find it useful to suthne some of the characteristic aspects of social banditry in Ottoman umes. For it reflects the tradittonal form of social banditry which continued to exist during the War of Independence perhaps with slight modifications.

[8] The nobility, backeci by the Levents, extracted illegal taxes to secure their future. This caused splits among the people and the local rulers. The 'Levent' status was abolished in 1776 (Ozturk 1990, p. 983-984).

[9] Ozturk refers to a specific tribe called the 'Reyhanli' tribe. The population of this tribe was more than 50.000. and they could provide 6,000 soldiers when needed. This tribe became involved in banditry over time. Ozturk assumes that this was the end result of the struggle between the Ottoman government and the 'Reyhanli' tribe which stemmed from the efforts of the government to settle down the 'Reyhanli' tribe in a designated area (1990, p. 975.976). The conflicts between the 'Reyhanli' tribe and the govemment continued until the mid-nineteenth century when they finally were forced to settle down. Ulucay, who examines brigandage and popular movements in Saruhan (located in Western Anatolia) during the seventeenth century, also argues that the efforts of the government to settle down the tribes were rarely successful. The Turcoman. Yoruk, and Kurdish tribes were almost always against the government and this remained a major problem until the end of the nineteenth Century (Ulucay 1944, pf. 90, 95-96).

[10] The family known as the 'Kucuk Aliogullari' gained so much power that at the end they formed an influential dynasty. At the beginning of the nineteenth century they were a real threat to public safety (Ozturk 1990. pp. 978-980)

[11] Stojanovic looks at the 'haiduks' and 'klepts' in the verbal Balkan folklore such as myth. legend. poem. tale, proverb, anecdote, joke, toast, saying, and comparison. He also refers to some famous haiduks and klephts in the Balkan region. 
[12] A great part of the Ottoman army was in continuous war against the rehels in the Arah prow inces which further contributed to social banditry. David Fraser. who was the Special Comespondent is 'The Times'. in his memoirs writes that, "when I was in Baghdad in February there vere nu less than five distinct military expeditions in the field against refractury tribes, requirements that had reduced the garrison of the headquarters of the Sixth Army Corps from sone thousands to as many hundreds. despite the fact that several battalions of reservists had been called out" (in $\mid 9(9))(19 \mid 10$. pp. $\$ 16$. $\therefore: 7)$.

[13] Armstrong was the Assistant and Acting Military Attache to the High Commissioner in Istanhul. He supervised the Turkish Gendarmerie. Previously he had been a British officer durng Wirld War 1.

[14] Armstrong describes Ankara, which then was a town, durng World War I. As he writes, "the marketplace was full of triangles on which hung the bodies of many brigands and deserters; fir all the country was disorganized and discontented, and robbers had made every road unsale" (1925, p. 36).

[15] When Ethem first appeared in the scene after the occupation of Izmir he was able to gather three. hundred armed men with horses from among the villagers where he lived. At this time he kidnapped the son of a former Unionist leader and held him for ransom. In this respect. he was involved in bandit- like activities since the beginning of his mission (Hicyilmaz 1993. p. 152: Egulmez 1981, p. 37).

[16] I refer to his band further when discussing the non-Muslim opposition movements against both Ankara and Istanbul governments.

[17] Bozdemir notes that smuggling of arms and munitions started even before the ending of World War 1 . when the Turks sensed that they were going to be defeated. The arms were hidden for a possible defence in the future (1982.p 83).

[18] On October 18. 1923 the law regarding the elimination c: rigandage passed the Assembly (Izale-1 Sekavet Kanunu) (Aybars 1988, p. 218). The passing of this law became an effective means in the elimination of banditry to a considerable extent. 
119] The Circassians in Turkey are onginally from the Caucasus. As a result of the war between Russia and Caucasus which took place in mid-nineteenth century. Circassians migrated to Anatolia in large numbers. Constitutung one of the 'millets' of the Ottoman Empire. they did not demand independence from the Ottuman state. Some of the well-known military leaders of the nationalist movement. who formerly served in the Ottoman army, were Circassians. However. there were Circassians who supported the Ottoman government against the Nationalists since they have always been loyal to the Palace and to the Sultanate-Caliphate (Sener 1986, pp. 21-24).

[20] The Muslim population is divided between the Sunnis and the Shiis, including Turks as uell as Kurds. The Alevis of Turkey are mostly known as the Shiis. However, Alevis represent the Turkish verston of Shiism which incorporates elements of Sufism. folk culnure. and Shamanism (a Shaman is an unspecialized medical, magic, and religious practitioner, often also called a medicine man or witch-doctor). Among the Kurds, "no estimates are available, but on the basis of the popular estimate that $70 \%$ of all Kurds in Turkey are Sunnis, most of the remaining $30 \%$ should be Alevis. after the exclusion of the Yezidis (ca. 10,000?)" (Andrews 1989, p. 116).

[21] Kabacali refers to a book published by a Russian officer. According to the author of this book the Hamidiye was not primarily furmed to gain from their military power against the Armenians but formed to control the Kurdish tribes who never really felt attached to the Ottoman society. The Hamidiye by offering uniforms, official military positions, and social privileges to the tribe members made the Kurds serve for the Sultan (1991, pp. 18-19). Mumcu argues that, the Hamidiye were established not only against the Armenians but with the purpose of dividing the Kurds among themselves in order to have better control over the tribes. It was assumed that the Hamidiye would strengthen the already existing divisions between the tribes and thus prevent their unification against the Ottoman government (1991, p. 54).

[22] Some Hamidiye commanders became very powerful over time. Some even received the title of pasha. Van Bruinessen refers to Mustafa pasha, a Hamidiye commander, who established his own 
'kingdom' where the Ottoman government had no control over him. The Harnidive often flouted lan and order. mostly without being punished (1992, pp. 186-187).

[23] A Hamidiye commander. Ibrahim Pasha, revolted when the Young Turks put an end wo Atudulhamad's rule. He did not recognize the new regime and declared himself independent favouring the Sultun. When the army defeated him. five thousand of his men offered their submission to the Turks (van Bruinessen 1992, p. 188).

124] Herbert, who was an honorary attache to the Bntush Embassy at Istanbul, refers to a secret intervieu he held with Talat Pasha in 1921. Talat was the political leader of the Young Turks, and he was accused of being responsible for Armenian depontations and massacres. As Herbert writes. Talat lold him that he had twice opposed enforced migration, and that he had been the author of an inquiry which resulted in the execution of a number of guilty Kurds and Turks (1924. p. 32.3). Enver Pasha. as the military leader of the Young Turks, was also held responsible for Armenian massacres. Binth Enver and Talat were later murdered by Armenians. As Gates writes, after the war ended, the Ottoman government had declared that it would return the deported Chnstians to their homes. restoring their property and compensating their losses. However, the succeeding cabmet did nux lake up these measures (1940, p. 251). There were exceptions with regard to returning Armenians. As Price writes, a considerable number of Armenians had retumed to their homes at Konya after the signing of the Moudros Armistice. These Armenians had voluntarily remained in their homes when the British offered to evacuate them. However, they were under military surveillance as the number of Turkish munition factories in the town grew. After a while all Armenian men of military age were deported into the interior of Anatolia (1923, p. 175). Mustafa Kemal, in a military report he wrote in 1920 notes that 250,000 Armenians and Rums froms the United States had came to istanbul after the signing of the Moudros Armistice (Ataturk 1991, p. 176).

[25] Adivar writes that there were rumours about Amenian attacks on Turkish villages and Armenian deportations with bloody consequences. It was long after these events that the Otionan govemment published a book on the subject exposing the crimes in Eastern Anatolia. As Adivar nores, when 
these deportations became known, public opinion tumed against the government. However, she also notes that. "in spite of the public disapproval of the governments's acts, every Turk was deeply conscrous of Turkey's danger, and that it would mean complete spoilation and extermination of the Turks if the Turkish army should be defeated. One nanurally felt that Armenian revolutionary centers were used as the strategic points to carry out allied policy against the Turks" (1926, p. 386).

126] Gates, too, makes the same comment. According to him, the Erzurum Congress (which as a regional one compared to the Sivas Congress), aimed first of all to defend the eastern provinces against the possible formation of an Armenian state in the region. The Allies wished to assign part of these provinces to the Armenians (1940, p. 272). After the ending of the war some form of American mandate in Turkey was considered. Morgenthau, who was the American Ambassador to Turkey, was among the ones who suggested an Armenian parliament in Armenia, and a Turkish parliament in Anatolia with the possible Turkish capital at Konya (1922, p. 337). In 1919 there was a large group of influential Turks in the capital who pledged themselves to accept an American mandate over the entire country. preferably for fifteen or twenty years (Price 1923, p. 132).

127] Topal Osman formerly was a soldier who fought both in the Balkan War and in World War I against the Russians. Mustafa Kemal, by the end of 1920. asked Topal Osman Aga to form a 'guarding force' (muhafiz birligi) from among the Lazes of Giresun for his personal protection. The 'guarding force'. which was named the 'Kara Zipkalilar', came to Ankara headed temporarily by Osman himself and protected Mustafa Kemal from then on (Sener 1992, p. 34). Later in 1922, they became "The President's Guard" consisted of two hundred and fifty volunteers to protect both the Assembly and Mustafa Kemal (Sener 1992, p. 82). The story of the 'Kara Zipkalilar' is told through a dasitan known under the same name. They originally were the forces which achieved success against the Russians during World War 1 .

[28] Price refers to an organization formed by Greek students in the American college at Merzifon. named the 'Pontus Literary Society' which was one of the centers of the Pontus movement. The Ankara government suppressed the college and deported its American teaching staff to Istanbul. A number 
of Greeks were arrested and tned before a military court in Ankara, sime of which were convisted and hung under the charge of treason in time of war. Pnice argues that all these effirts were mu enough to break the power of Greek organizations, and that the government was fo take mure seriuus steps (1923, p. 165).

[29] As Reed notes. the official statistics have made no distinctuon between (rothuxdox Sunni and heteridux Shiite-Alevi Muslims in Turkey for many years (1957, p. 120$).$

[30] In the Ottoman Empire there was unity between Sunni Muslims regardless their ethnic and linguistle differences, such as the Sunni Turks, Sunni Kurds, Sunni Arabs, and other Sunn ethnic groups. This unity was fostered by the Onoman sultans. In this context. the Hamidiye militias. which were formed from among the Sunni Kurds, were a successful attempt in binding Sunni Kurds to the Sultan (van Bruinessen 1992, p. 268).

[31] Van Bruinessen's study of the Kurdish social and political organization is now a classic work on the topic. I have extensively used his book since there are not that many reliable sources on the Kurds. especially with reference to past historical developments. He used the written scurces by Kurdish nationalists and Turkish authors, and interviewed the participants of the Sheikh Sait Revolt.

[32] Van Bruinessen notes that there is very little information about the Kurdish movements of early nineteenth century. He assumes that these movements were triggered by Ottoman Empure's subjection to the European powers (1992, p. 251).

[33] Van Bruinessen argues that these orders can be seen as an organizational framework for embryonic: class struggle. However. he also argues that he had found only partial confirmation for his argument; "I am therefore reluctant to extrapolate my findings and say that the onders do not (or not any more) anywhere in Kurdistan play a significant role in the mobilization and organization of people subjected to national and class oppression" (1992, p. 212).

[34] As van Bruinessen notes, once a sheilch establishes his power, and a network of local groups of followers has developed, this network may be used by members of the order for other purposes. including class-based action. However, he also argues that. the sheikhs would nut allow their 
foliowers to transform the order into a means of class struggle since some of these sheikhs thernselves were powerful land-owners (1992, p. 233).

135] According to van Bruinessen the Sheikh Sait Revolt constitutes a tuming point in the history of the Kurds. For it led to a new stage in the history of Kurdish nationalism. He focuses on this specific revolt because it exemplifies the rules of sheikhs and aghas in interaction with the state (1992, p. 265).

[36] One of the first Kurdish political organizations formed in Istanbul was the 'Kurt Teavun ve Terakki Cemiyeti' (Kurdish Society for Mutual Aid and Progress). This organization was formed during the period of Young Turk ruke, in 1908. However, it was banned by the Young Turks. Another Kundish political organization was the 'Kurdistan Teali Cemiyeti' (Society for the Elevation of Kurdistan). founded in Istanbul in 1918. It was formed by the members of the former Kurdish society, and had representatives from among the urban middle class and Kurdish tribes. Van Bruinessen believes that the Society for the Elevation of Kurdistan played an important role in those Kurdish revolts that occurred in Dersim and Sivas, in 1920. According to him although the leading members of this and other similar Kurdish organizations were mainly Kurmanji-speaking Sunnis, they managed to attract Alevis and Zaza-speaking Kunds. The risings in Dersim and Sivas, organized by the Society for the Elevation of Kurdistan, were risings among the Alevi Kurds demanding autonomy for Kurdistan. Van Bruinessen claims that these revolts were not provincial since the aim was to unite not only Sunnis and Alevis, but also to unite both Kurmanji and Zaza-speaking Kunds. However, the revolts were not supported by all Kunds for three reasons. First of all, these revolts were badly organized and lacked inter-regional coordination. Second, most Sunni Kurds saw these revolts as mere Alevi uprisings and did not support them due to traditional divisions between these two forms of Islam. Lastly. there were many Kurdish chieftains who supported Mustafa Kemal instead of the rising Kurds. For Mustafa Kemal had established personal relations with many aghas and sheikhs, and assured them that they would be protected under the new regime (van Bruinessen 1992, pp. 278-279). 
[37] Van Bruinessen suggests that the majority of the Kurds who panticipated to the revolt were the Zazaspeaking Kurds. Some Kurmanji-speaking tribes also participaled (Jibran and Hesinan). Howecter. he adds that detailed information about all the tribes that had particupated in the revolt - and the extent of their participation - is still missing (1992. p. 293).

[38] The question of Mosul remained unsettled since the Lausanne negotiaturns. The Bntush claum fo Mosul province, which is rich in oil. was accepted by Ankara government. and a treaty was signed at Ankara between Turkey. Britain. and Iraq in June 1926. With this treaty Turkey gave up all its nghts to Mosul in retum for ten per cent of the oil produced in the area.

[39] Kinross writes that there was a hostile public reaction to this revolt especially in Istanbul. In h1: words. "in Istanbul the students and the porters - the intelligentsia and the proletariat - had come out strongly against these manifestations of religious reaction" (1965. p. 402).

[40] Many decrees followed aimed to break the traditional role played by religion. Nol only sheikhs and dervishes were attacked. but fortune-telkers, magicians, witch-doctors, writers of amulets for the recovery of lost property or the fulfillment of wishes, as well as services, dues, and costumes which belonged to these titles were all forbidden. In addition all sacred tombs were closed as places of worship (Kinross 1965, p. 412).

[41] All Turkish sources about Kurdish revolts refer only to one book which is written by a resıgned Turkish colonel, Resat Halli, in 1972. The book is named 'Revolts in the Turkish Republic (19241938)', and is the only available source on Kurdish revolts. This is a serious handicap for a detailed analysis of Kurdish movements. There are few Kurdish sources written by Kurdish nationalists.

[42] Yalcin-Heckmann refers to one uprising that occurred in Hakkari's Oramar region. This was an attempt to weaken the Turkish military operations to distract the Turks away from Agrn (Ararat). The local tribesmen were again divided among themselves. While some supported the group of Barzani leaders from Iraq who had actually started the uprising, others wete fighting on the Turkish government's side. Those who supported the government secured for themselves the local political 
itfices, and the topic of who supported or fought against the government forces has been brought up in intra-tribal conflicts as senous accusations (1991, p. 70).

[43] As discussed before. Kurdish attacks on government officers have been the most commonly practused form of resistance aganst central authonty. Yalcin-Heckmann, who conducted an anthropological study on the Kurdish tribes in the province of Hakkari, writes that. "the distinction made between the Ontoman Sultan and his administrators could also be observed in Hakkari's history when tribes rebelled against the centrally appointed administrators but were quickly appeased by some favour or message from the Sultan. The local rulers of the tribes made this distinction a crucial part of their strategies in order to fully exploit the political resources" (1991. p. 116).

[44] The fez was first introduced by Sultan Mahmut II to replace the traditional headgear known as 'turban'. At that time the Greeks also wore the fez. The introduction of fez then was a revolutionary step which caused serious opposition and riots among Otomans. especially in Bosnia which was then part of the Ottoman Empire (Yalman 1956, p. 174; Kinross 1956, p. 413). The fez was first adopted for military reasons. When Sultan Mahmut II exterminated the Janissaries, he introduced the fez to his new army since the was determined to replace all cloching that symbolized the Janissaries. According to Berkes the fez originally was a kind of hat wom in Morocco and Algeria. It soon replaced the traditional 'turban'. The fez first became a symbol of separating Turks from the Europeans. During Abdulhamit's rule, which was a period characterized by growing religious fundamentalism. it began to represent loyalty to Othodox Islam (Berkes 1978. pp. 194-195: Karal 1971. pp. 156-157).

[45] Kinross writes that the idea of hat reform was discussed in the press, "but still no newspaper dared use the ugly word 'shapka'. or hat. They preferred such euphemisms as 'civilized headgear'. 'protector from sunshine'. or 'head-cover with a brim' (1965. p. 413). This fear of using the word 'hat' indicates the fact that the fez was so strongly representative of religious identity at the most personal level.

[46] Kinross writes that, in 1923, a deputy sugecsted in the Assembly that women should be included in the census for representation under the new electoral law. However, his suggestion was not 
welcomed at all even though he argued that this wivuld mot mean giv ing them the nght fo vike. The deputy was howled down. and he was prevented frum tinıshing his specih (1465. p. $4 \mid 0)$.

[47] Adivar writes that Turkish children could nut leam 6 read and write with the Arabk letlen in less than a year (1929, p. 39).

[48) Although the Koran was then translated to Turkish. and prayers sand in Turkash, this prak'the dul mu continue for long. Today the Koran is still printed in Arabic. and Friday prayers are suld in Arathe as well. 


\section{CHAPTER 5 THE IMPACT OF RESISTANCE ON THE STATE-BUILDING PROCESS IN TURKEY $Y$}

\subsection{Introduction}

In Chapter Four, I discussed the various forms of resistance provoked by the process of state formation in Turkey. Here I analyze not only the shifts in the forms of resistance experienced in Turkey but also the link between these shifting forms of resistance and the Turkish state. I also analyze the impact and consequences of these various forms of resistance for the building of the modem Turkish state.

I will argue that Turkish nationalism developed as a response both to foreign invasion and to the development of non-Muslim nationalisms. Non-Muslim opposition had a strong impact on the form of the new Turkish state. In addition, non-Turkish resistance to the 
Sationalists. too. significantly influenced the form of the state and its policies tomards building a nation-state. Turkish nationalism and particularly secularism provoked furtier resistance among both the Turkish and Kurdish population. The modernizing policies of the new state. partly in response to the resistance movements experienced earlier. and partly as part of the modemizing process. created new tensions giving rixe to new firms off opposition led by religious. cultural and ethnic groups. These movements that oxcurred after the establishment of the Turkish state in 1923 produced a more authoritarian stalc which denied the existence of separate cultures. Moreover, populism (which aims at creating a society free of economic class divisions). together with nationalism and secularism. became the major legitimizing ideology of the new regime in establishing its authority.

\subsection{Forms of Resistance and the Turkish State}

The process that made the new Turkish state different from the Ottoman state in the eyes of local populations was complex. As Sugar points out. the replacement of the new administration with the old was not reall: something new in the eyes of the majority of citizens since a good number of the same men sat behind the desks in the various offices and the government as a whole looked rather familiar (1964, p. 161). Toker, 100, argues that many were not aware of the fact that the Sultanate had been abolished (1994, p. 46). It is necessary to trace critical points of transition that promoted change in the forms of resistance. For these new forms of resistance reveal the changing perceptions of the state. Furthermore. the consequences of resistance for the state-building process can be better located by determining these critical points of transition. 
The concept of state-building needs some clarification at this point. First it is necessary to distinguish between 'state-building' and 'state activities' since there were different kinds of resistance movements against state-building on the one hand. and against state activities on the other. As pointed out earlier state-formation may take different forms in different locations, and this applies to state activities as well.

When locating these critical points of transition that initiated change in the form of resistance I will discuss the nature of the link between these transformative processes and the state. focusing on the role played by the form of resistance in structuring this relationship. In this context I look at the consequences of growing nationalism and ethnic consciousness. World War I and the Turkish Independence War. Treaty of Sevres, nonMuslim claims for independence, social banditry and internal rebellions. establishınent of the Courts of Independence, the Kurdish nationalist movement, and lastly the constitutional developments and the reforms that followed it. Among these the Turkish War of Independence had revolutionary consequences. The rest were transformative developments, some with immediate visible consequences and others with more hidden agendas. Nevertheless all produced some form of resistance which had a further impact on the process of state-building. in terms of shaping the new state and its policies.

What follows is a discussion of the link between the state and these various forms of resistance under separate headings focusing on the ways through which the state became more and more structured following the model of West European nation-states. 


\subsubsection{Nationalism}

Westernization had an impact on the Turkish Revolution but it cannot te argued that the Turkish nation-state was a natural outcome of the modernizing reforms of the Ottoman state. This orientalist perspective does not explain the impact of the internal cleatlages on the development of the Turkish nation-state. It is difficult to conceive of the Turkish Revolution as an anti-imperialist movement since Turkey was never colonized and an anti-imperialist sentiment did not exist among the population. The Turkish nation-state was formed by those bureaucrats who were educated in the West or were in close contact with Western ideas and developments. The connection between the 'West' and 'Turkish nationalism' is problematic and the nature of this link is subject to continuous change.

To begin with. I highlight some aspects of Turkish nationalism in order to better licate various movements of resistance by non-Muslim and Muslim minority groups. The impact of Turkey's ethnically diverse cultural and historical background on the formation of the Turkish nation-state is particularly significant in understanding the internal pressures which played a role in the development of Turkish nationalism.

I argue that Republican Turkish nationalism was not able to bridge the gap between ine traditional Ottoman cleavages. For Westernization and secularization continued to be important sources of tension which created new conflicts. In this respect Turkish · nationalism was unique in comparison with other forms of nationalism. Its uniqueness existed of two features. First, it is distinct from classical (Westem) forms of nationalism due to the tension between the 'West' and the 'traditional' ways of life. Second, it is 
distinct from other non-European Islamic nationalisms through the rejection of Islam as the universal basis of legitimation.

Part of this uniqueness stems from the Ottoman 'millet' system as discussed in Chapter Two, section II.2.3, and Chapter Three, section III.2. The millet system, which was based on ethnic and religious differences, can be seen as the basis of the segregated Ottoman society. In this respect the political system of the Ottoman Empire radically differed from West European political systems. However, if in the West the term nation-state means the political and territorial expression of a 'nation'. which is conceptualized as the people possessing common traits such as language, shared history, etc. The transfer from religious, dynastic, or multi-national states to single-nationality states applies both to the West and to the Ottoman society. Nevertheless, the process of Turkish nation-state formation cannot simply be seen as an extension or manifestation of the European pattern. The internal dynamics of the Ottoman state and the impact of the West created specific historical circumstances out of which the Turkish nation-state emerged. Consequently, nationalism in the Ottoman Empire should not be seen merely as a transfer of loyalty from the religious to the political institutions (Cesur-Baykan 1988, p. 42).

In the Ottoman Empire the millet system grouped various sections of the population according to their religious and ethno-linguistic affiliations, disregarding their occupational status (Karpat 1973, p. i). Among these millets were the Muslims, Orthodox Greeks, Gregorian Armenians, Jews, and Catholics. The term 'millet' originally meant 'religious community'. As Lewis notes, in the Ottoman Empire it became a term applied to the organized and legally recognized religious communities, such as the Greek 
Christians, the Armenian Christians. and Jews. In the Empire. there was a Muslim millet. but no Turkish or Arab or Kurdish millets. There were also Greek, Armenian. and Jew'sh millets, but as religious communities. not as ethnic nations. While Greeks and Slavs formed part of the Greek Orthodox millet. Gregorian and Catholic Armenians formed separate millets (Lewis 1968, p. 335).

This system produced a series of 'nationalities' or 'nations' which carried the Ottomian stamp. The millet system. which was based on religious differentiation, reflected the communal order of the Ottoman society. As Berkes notes. with the transformation of Balkan nationalities into separate nation-states, the term 'millet' appeared as a designatiot. for the Muslims in parallel with the non-Muslim 'millets'. However, the term 'millet' only later began to be associated with 'nation'. In Berkes's words. “during the Hamidian era. the Turk was not yet differentiated from the Muslim. The 'millet' of Muslims, now believed to be the sovereign 'millet' of the Ottoman Empire, still meant a religious community, which is the correct meaning of the term" (1964, p. 318).

Briefly, nationalities in the Ottoman Empire functioned as a form of communal organization and each was controlled through the millet system. In this system nationalities can be equated with religious-ethnic communities. Ethnic and national identities among the former Ottoman peoples is fundamental to an understanding of Ottoman nationalism. For the nationality problem in the Ottoman state is a special form of nationalism which is different both from the Westem Euro: ?an and the recent Asian and African nationalisms (Karpat 1973, p. 3; Haddad 1977). 
These ethnic and linguistic attachments stemming from the millet system had no political significance until late in the eighteenth century. With the Ottoman transformation in the late eighteenth century the old ethnic and religious communities came to operate as the basis of emerging nationalities and nations with a corresponding change in group identities. In other words, ethnic identities were associated with claims to political independence from the Ottoman state. These Ottoman populations did not totally deny the millet system but redefined that system. In this respect, the millet system can be seen as the basis of various nation- states which emerged out of the Ottoman breakdown. Turkish nationalism was only one of the nationalisms which emerged out of the Ottoman Empire. The others were Greek, Serbian, Bulgarian, Romanian, Albanian, Armenian, Kurdish, and Arab nationalisms.

This argument stands in opposition to various other interpretations. For some the Ottoman Empire was already a Turkish state even before the establishment of the Turkish nation-state. For others the establishment of the Turkish nation-state was merely a change of regime, or a consequence of pure Westernization. I argue against these positions. First, because the Turkish state was a secular and a modem nation-state it radically differed from the Ottoman state. Secondly, Turkish nationalism was not the natural outcome of the modernizing reforms of the Ottoman state. This diffusionist perspective cannot explain the still dominant cleavages in the Turkish society. However, Westernization is important to the extent that it can explain the rupture from traditional ways of life which in turn can initiate further change. In the Turkish society the tension between the Western and antiWestem forms of life has existed since the beginning of the republican regime in varying 
degrees and forms. and this tension has been a powerful source in mobilizing various sections of society.

At this point the main issue is to discuss how Westernization and modemization merged with Turkish nationalism. Another is to elaborate on non-Muslim opposition in relation w the growth of Turkish nationalism.

The Ottoman Empire did not have a 'central value system' due to its segmented structure. In Keyder's words. "the Ottomans lived in a multicultural empire. The ruling Turks had never attempted to impose a cultural homogeneity on the ruled 'millets'. Besides, this ruling ethnic group had made no attempt to remain pure, and interethnic marriage hild been a constant in the practice of the upper classes" (1993. p. 19). Ottoman segmentation was religious. linguistic, and ethnic. In addition to this segmentation, the Islamic population was made up of Sunnis and Shiis. When the Balkans started their revolutionary movements Ottoman reformers attempted to unite all these segmented groups under the umbrella of 'Ottomanism'. In Mardin's words. Ottomanism was “a concept based on granting a common Ottoman citizenship and the rights pertaining thereto to the persons who up to that time had only had the corporateness of the segment to which they belonged as a source of group identity. For the Muslims this had been Islam. Members of various other religious groups were now all to count as Ottomans. More radical reformers urged the adoption of constitutional govemment in addition to Ottomanism as a cement that would hold the Ottomans together. Others proposed that Islam should fill this function" (1977, p. 284). 
As Lewis points out, there was no Ottoman nation but many nations held together by a common allegiance to a dynastic sovereign. In Lewis's words. "the Ottoman liberals, and after them the Ottoman constitutionalists. tried to replace that allegiance by a new Ottoman patriotism. which would group all the many peoples of the Empire in a single political loyalty and identity" (1968, p. 339). However, this policy failed to bring ethnic uniformity to the Ottoman society as a consequence of the growth of nationalist movements in Europe affecting the Christian peoples of the Empire most. In Lewis's words,

When the national idea conquered them [Christian minorities], they began to think of themselves, not as Ottomans, but as Greeks. Serbs, Bulgars, and Armenians...The struggle of the Christian peoples for national independence and the Turkish reaction against it - armed insurrection and armed repression - created a new bitterness between Muslims and Christians. The Bulgarian rising of 1876. the Armenian revolutionary movement of the 1890 's, the Cretan insurrection of 1896-7, the activities of the revolutionary committees, the famous komitadiis, in the Balkans, all helped to create in the Turks a profound mistrust of their Christian compatriots and of the European great powers looming behind them; at the same time the repressions and massacres with which the Turks responded reinforced the determination of the Christian peoples in the Empire to seek their salvation, not in citizenship, but in separation (1968, p. 340).

The Young Turk movement was the response to the failure of Ottomanism. The Young

Turk government formed in 1908, in a way, followed the same principle of Ottomanism to unify the Ottoman society. However, they were the first to try to bring about cultural and educational unification as a solution to the Empire's problems. After the start of the second constitutional regime in 1908. 'Pan-Islamism' and 'Turkism' became important systems of thought which led to the development of Turkish nationalism. Ottomanism, Islamism. and Turkism existed as three competing ideologies. As Berkes notes, "the interests of the three major elements in the Ottoman Empire - the Turks, non-Turkish 
Muslims, and non- Muslims - did not altogether coincide. It was inevitable to recognize the national aspirations of the non-Turks and non-Muslims. Hence, there was only one thing left for the Turks: to recognize their own national aspirations, to forget about being Ottomans, and to be content with being Turks" (1964. p. 322). In view of these points I highlight some elements of 'pan-Islamism' and 'Turkism'.

With the growth of Arab nationalism the Ottomans tumed to Islamic brotherhoxd as a source for a new identity rather ihan the ideal of a common Ottoman citizenship. Islam was seen as a protection against the growing Western influence on a new basis for it was defined in cultural rather than political terms. As Lewis notes, "even after the deposition of Abdulhamid, the Young Turks continued to enjoy the support of the Muslim world in their struggles against their Balkan enemies, and pan-Islamic solidarity was a matter of grave - indeed exaggerated - concern to the Allies in the World War 1 . The last flickers of pan-Islamic sentiment can be seen in the pathetic intervention of the Indian Muslim leaders on the question of the Caliphate in 1923" (1968, p. 343). Pan-Islamism did not play a more powerful role than traditional Islam.

The Young Turks aimed at maintaining the existing Ottoman multi-national state and to 'Turkify' it. Turkism became much more infuential among the Turks compared to panIslamism. With the development of Arab and Albanian separatist movements after 1911 the Muslim millet had disappeared, and Turkish nationalism eventually became a fundamental principle of political organisation under the leadership of bureaucratic elites according to the model of a nation-state (Karpat 1973, p. 113). However, the development 
of 'Turkish national identity', and of a 'Turkish nation' as distinct from the Ottoman state was a very slow process. As Keyder states.

The imperial bureaucrats did not readily take to Turkish nationalism. even though all the other 'millets' in the Empire had already embarked on nationalist movements of their own. After attempts at Ottomanism, foiled by the inability to strike a compromise with Armenian separatism and Hellenic irredentism. and a doomed endeavor to rally the population under the banner of political Islam. which foundered on Arab nationalism. Ottoman intellectuals seized upon an imitated nationalism which, more than in similar cases, had to be invented and constructed from scratch (1993, p. 21).

The most important source for the ideas of Turkism was the new European science of Turcology. Lewis argues that, from the eighteenth century onwards a series of Orientalists had studied the history and languages of the eastern and pre-Islamic Turks. These works made available the history and the role played by the Turks before they entered Islam. When this new knowledge reached the Turks themselves, it greatly affected their sense of identity and their relations with other groups. According to Lewis's argument this new Turkish identity slowly merged with spreading European nationalism (1968, p. 345). Berkes, too, stresses the imponance of these works on the history and philology of the Turks in pre-Islamic times in the formation of Turkish nationalism. However, as he argues, these works did not become influential in the short run (1964, pp. 313-314). Nevertheless, in the long run, they contributed to the creation of, what Smith calls 'ethnic myths'. which bring together historical fact and legendary elaboration to create an overriding commitment and bond for the community (1984, p. 95).

It was during the Young Turk rule that Turkish nationalism, for the first time, appeared as a possible direction to be followed as a solution to the empire's problems. Nationalism 
was slowly adopted as a model to be followed. As Smith argues, at the heginning

Turkism was based on tracing a cultural and ideological attinity with the qualities and virtues of their alleged Turkish ancestors. As he writes.

One aim of these Turkist historians was clear: to free their people of scli-contempt and self-ignorance through historicist education. The temporary bifurcation between a wider racial and linguistic pan-Turanianism and a more strictly ethnic pan-Turkism was soon settled in favour of the latter. but both served to raise the pride in self of Turkish intelligentsia and restore the credibility of the Turkish community. In the end, a more limited westernising Anatolian Turkism won out: Ataturk turned his back on foreign adventures and the Central Asian homeland, yet his followers remained profoundly influenced by their pan-Turkist background (1984. p. 113).

Another important source for the development of Turkish nationalism came from the Russian Turks. Among these were Muslim Tartars and the Turks from the Volga. Central Asia, Azerbayjan, and Crimea whom were coming to live in the Ottoman Empire towards the end of nineteenth and the beginning of twentieth century. The well-educated exiles from Russia. affected by the revolutiv nary tendencies of the Russian Empire. played a major role in the spread of Turkish nationalism as a political ideal (Lewis 1968. p. 348). Keyder notes that in addition to Turkic groups in the Russian empire. Turkic groups in the Austro-Hungarian empire also played a role in the growth of Turkish nationalism (1993. p. 21 ).

The development of Turkish nationalism, as discussed earlier, began as a cultural movement rather than a political movement. First ideas of Turkism were developed in the literary and educational fields. Linguistic developments also contributed to the growth of Turkism. As Adivar writes, 
While the Ottoman Turks were trying to revive ancient Turkish mythology, and introduce old Asiatic Turkish words into the Ottoman Turkish vocabulary, the Turks in distant lands were meanwhile reading and studying the Ottoman literature and classics. The realization of this mutual cultural affinity of Turks all over the world had a great effect on some of the Turkish writers in Istanbul. While the greater number of Turkish writers continued with the work of bringing the colloquial and purer words back into literature, those few Pan-Turanist writers dug into Asiatic legends and introduced subjects, heroes, words, which could not take root in the Ottoman Turk's language (1930, p. 120).

The Ottoman language was a mixture of Turkish, Arabic, and Persian languages. With the linguistic developments that took place since the Abdulhamit era, the Ottoman language eventually became disintegrated and gave rise to a Turkish language as the language of the Turkish nation. In the early thirties the institutions of the 'Turkish Language Society' and the 'Turkish History Society' were established. These institutions underook research to support the new regime's vision of Turkish nationalism. The Turkish History Thesis. which assumed a historical link between the Central Asian Turks and the ancient Anatolian civilizations, was a result of such research (Ozturkmen 1994, p. 159).

The Young Turks were more inclined to strengthen the centre rather than carry out reforms. They were more dedicated to the principle of unifying the Ottoman Empire. In this respect it was not Turkism but Ottomanism which was their programme. In Berkes's words, "the ideas of a Turkish nationalisra did not invite the interest of the Turkish intellectuals. Neither did such ideas stimulate the Young Turks. The three factions of the Young Turks all advocated Ottomanism, opposed the nationalisms of the non-Muslim and non-Turkish groups, and entertained no ideclogy of a Turkish nationalism" (1964, p. 321). However. as a result of the growing cleavages between various nationalities of the 
Empire. Onomanism gave way to Turkism. This new Turkifying movement brought about the disappearance or submission of the other Ottoman ethnic groups.

During the Young Turk rule. as discussed in Chapter Two, various Turkish Clubs were established throughout the country. The first was 'Turk Dernegi' (Turkish Society). Founded in 1908 Turkish Society dedicated itself to the study of Turkish people - their languages, history, literatures, and civilizations. Another organization, known as the 'Turkish Heart' (Turk Ocagi), was founded in 1912. These clubs were effective in spreading Turkish nationalism. Although they were cultural organizations they did help Turkism to gain a political outlook rather than a cultural one. Nevertheless Turkish nationalism, even in the early days of the Yoling Turk rule, remained ineffective as a political principle. Non-Muslim opposition became a turning point for the transformation from cultural to political Turkish nationalism.

\subsubsection{Ammonian and Creak Minoritios}

It was under these conditions that the struggle between the Ottoman and the Christian minorities gained a new impetus. The old system of multi-ethnic and multi-religious empire had already been destroyed. The relationship between the Ottomans and nonMuslims began to change drastically. During the first phase of the state-building p.ocess, the nationalist appeals made by non-Muslims and the uncertain situation in Turkey resulted in oppressive measures against the Christians. Attacks on Armenians during the Young Turk rule was part of the policy to strengthen the central Ottoman govemment. As Lewis notes, the Armenian community was known as the most loyal community (Millet-i 
Sadika) to the Ottoman Empire. and the one most trusted by the Turks (1968, p. 356).

However, this relatiorship began to change with the Russian conquest of the Caucasus in early nineteenth century and with the formation of a Russian Armenia on the eastern border of Turkey.

According to modernization theories. Turkish nationalism is regarded as a consequence of the spread of European nationalism and European social values which accompany it. However, this position can be questioned reganding the link between the rise of Turkish nationalism and Christian opposition movements against the Ottomans.

The Armenian community was more than an ethnic community. They fought for their independence claiming parts of the land they had shared with the Turks for centuries. They were scattered throughout Anatolia and lived side by side with the Turks in the same villages. The Greeks of Anatolia, too, shared the same territory with the Turks and the Armenians. Since the Turks, Armenians, and Greeks did not live in segregated areas, the conflict between them turmed into a bitter struggle as a consequence of territorial claims. As Berkes notes.

The Balkan nationalisms did not originally have the effect of stirring up Turkish nationalism. The situation changed when national movements appeared among the non-Muslims in territories that could not be ceded from the Empire without injury to the Turkish population. Most influential was the rise of an Armenian nationalism. In the Ottoman system the Armenians constituted a 'millet' that did not have a territorial basis and was, therefore, incapable of being transformed into a nation-state. In addition, the schismatic struggles since 1847 amung the Gregorian. Catholic, and Protestant churches not only shattered the Armenian 'millet'. but also severed it from its traditional status in the Ottoman system (1964. p. 318). 
Consequently the age-old distinction between Muslims and non-Muslinss + came the basis of a new form of struggle. A new discourse of saving the Muslim Ottoman Empire from its Christians rivals became the principle to be followed by the Otfomans. since they made territorial and political claims that threatened the existence of the Ottomian state. In reaction to these demands the Ortomans took more repressive measures against its constituent minority groups. The Ottoman officials were able to legitimize their effionts io save and strengthen the state becanse the state they represented was the siatc of the Muslims, not of the non-Muslims.

These deveiopments contributed to the development of Turkish nationalism which was not yet a secular form of nationalism. The non-Turkish Muslim population played an influential role in shaping the future of Turkish nationalism.

The decisive factor in converting this religious nationalism into a secular form was the rise of rationalist movements among the non-Turkish Muslim peoples. The Arab and, to a lesser extent. Albanian, and Kurdish. political movements were not yet genuinely nationalistic. iney entailed only demands for autonomy, or political separation. Their ideologies were still in infancy and confused. Howe ver, the process of transformation in the traditional self-concept of the Arabs and Albanians in particular played a significant, if indirect, role in the secularization of the Turkish nationalism (Berkes 1964. p. 319).

The events that took place between the Muslims and non-Muslims div ng the Turkish War of Independence further fueled the fears of Christian minorities. The Turks and Kurd on the one hand. and Armenians and Greeks on the other. were in a state of contınuous war which created fear and hatred among a'l against one another. The Treaty of Sevres, which was an approval for the nationalistic claims arade by the Armenians and Greeks, forced the Turks to develop a form of political nationalism which replaced the cultural 

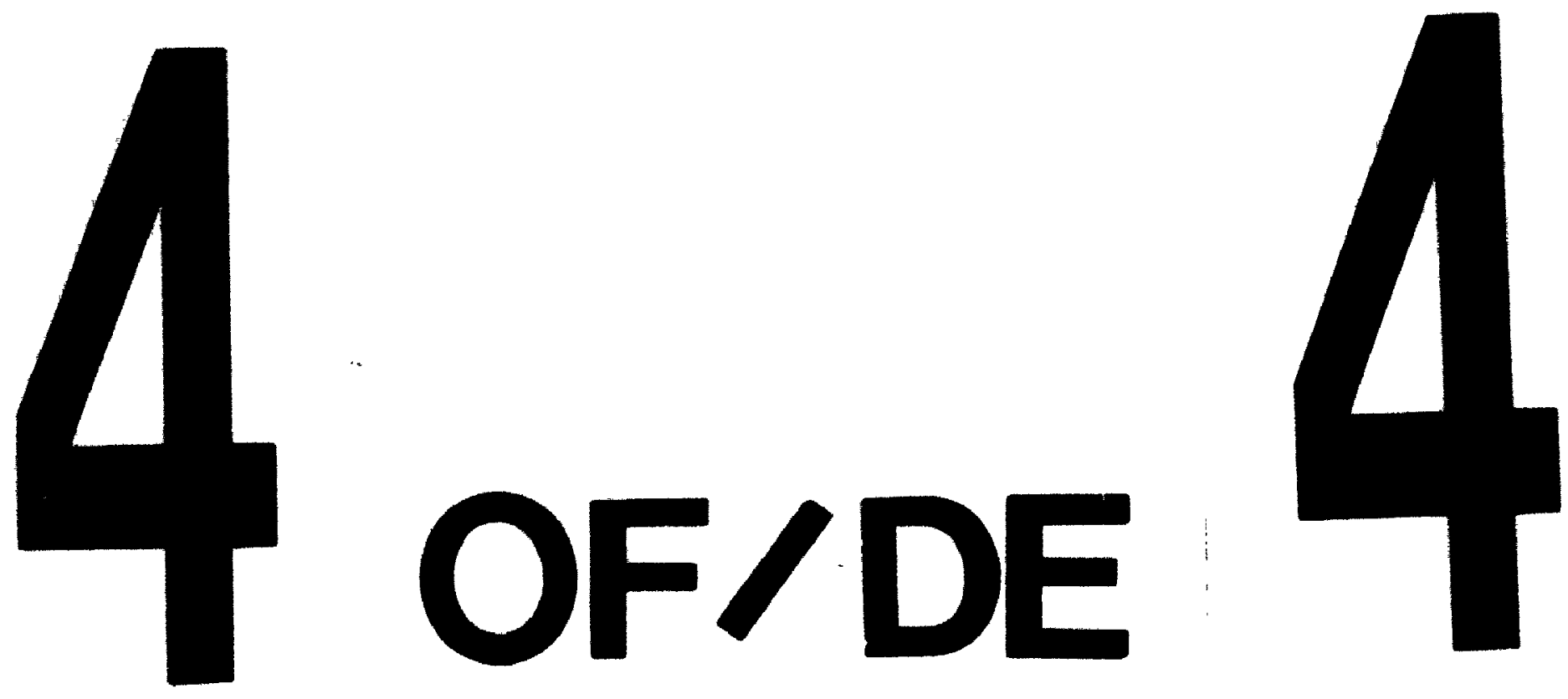

PM-1:, $1 / 2 " \times 4^{\prime \prime}$ PHOTOGRAPHIC MICROCOPY TARCET NaS 1010a ANSI/ISO "2 EOUIVALENT

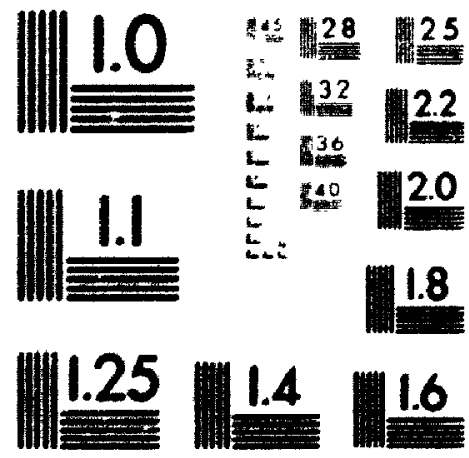

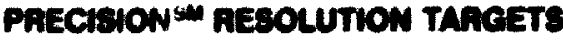


nationalism of the Young Turk era. The idea of forming a secular nation-state was based on this shift in the form of nationalism. It was not only non-.Muslim national movements but also the breakdown of the Muslim 'millet' that played an important role in the development of secular Turkish nationalism.

\subsubsection{The Idea of Nation-State}

Ottomans made use of both pan-Islamism and pan-Turkism during the Young Turk rule. Lewis argues that Islam and Turkism were both non-territorial and that both had no ties neither with a country nor with a government. Accordingly. "the Muslim Turks of Turkey might classify themselves as Muslims - by faith and law; or as Turks - by language and real or imagined descent: they had not yet thought of defining themselves as the people of a country - of Turkey" (1968, p. 352). Both trends proved to be ineffective sources in protecting the breakdown of the Ottoman society.

During the Young Turk Revolution, which saw the restoration of the constitutional regime (Mesrutiyet), the divisions between the Westernists, Islamists, and Turkists became more clear and rigid. Among these the Westernists constituted an influential source for future developments. As Berkes notes, “the Westernists' ideas deviated radically from the prevalent view of Westernization...The essence of Westemization in their eyes would be a radical moral and mental transformation. The greatest problem was to cast aside the old system of values in order to develop a new morality based upon the Western system of values. In other words, modernization was to the new Westernists a cultural and moral issue far more than a material one" (1964, p. 3.77). It can be argued that the Westernist 
school of thought, which merged with Turkish nationalism, became the most influential trend in shaping the future Turkish state.

Forming a modern nation-state, based on the Western model, was adopted by the Kemalists in the aftermath of the Turkish Independence War. The cultural nationalism adopted by the Young Turks gave way to a political nationalism similar to European ones. The first conception of a territorial Turkish state was introduced with the National Pact of 1919-1920. In addition. the signing of the Treaty of Sevres between the Ottomans and the Allied forces became a major factor in adopting the Western model of a territorial state from the West.

The idea of 'Turkey' was a very recent development. Adivar writes that. "the term Turkey, although used by western people in connection with the Ottoman Empire, was never used by the Ottomans themselves. It was used after 1908 at times, but never as much as the term Ottoman Empire" (1930, p. 158). Generally, the term Turk was a label used in the Empire to refer to the Anatolian peasantry (Keyder 1993, p. 21).

Although identity and loyalty based on the Turkish nation was introduced by the Young Turks, it was witt: he Kemalist republic that the idea of 'Turkey' as the land of the Turks came into existence (Lewis 1968, p. 353). The name of the country became 'Turkey' (Turkiye) in the Law of 1921, and in the Republican constitution of 1924.

Kemalism tried to combine the Ottoman statist icieal by modemising it with the liberal, federalist Anglo-Saxon models. Ataturk's ideology can be characterised as the denial of the past. as a search for a new national identity, and as an attraction to the West. 
Kemalism denied the expansionist tendencies of Islamism and Turkism. Within this framework it initiated resistance and opposition from among those groups defending their Muslim identity.

\subsubsection{Social Banditry and Internal Revolts}

In the Turkish case. social banditry was an effective form of resistance to the formation of the state. Social banditry, inherited from the Ottoman Empire. was a major challenge to the establishment of the central authority. Nationalists, on the other hand, relied heavily on bandit bands during the first phase of the Turkish state-building process.

In its traditional form social banditry was motivated mainly by economic reasons. However, during the establishment of the new state it became a form of resistance to statebuilding for political reasons. For example, there were bandit bands who allied with communists or with the Greeks against the Turkish government in Ankara, and they made political claims. In addition, some bands allied with the Kurds and with the Circassians, supporting their movement against the Ankara government. Yet there were a considerable number of bandit bands that supported the new government and helped the central powers in suppressing ethnic and religious movements that were undermining the authority of the Kemalists. Traditional social banditry also continued to exist alongside these other forms of banditry.

In general social banditry served both as an 'individual' and as a 'collective organized' form of resistance to state authority. Military desertion, too, became part of social banditry and merged with it both as an 'individual' and as a 'collective' form of resistance. 
Nevertheless, this form of movement. either supporting or resisting the Nationalists, remained precapitalist in form. Following Hobsbawm. they constituted what he called 'primitive rebellions' (Hobsbawm 1959).

According to Hobsbawm. social banditry is a universal social phenomena and it can merge with peasant revolt or revolution. Bandits, who share the values and aspirations of the peasant world, can become part of revolts in any peasant society between the evolutionary phase of tribal and kinship organization, and modern capitalism and industrial society $(1969$, p. 14). Hobsbawm suggests that, when social banditry merges into a larger movement, it becomes part of a force which can and does change society (1969. p. 23). This holds for the Turkish case. Social banditry did accompany the Turkish War of Independence. Although social bandits did not represent an organized peasant movement, many bands supported the Nationalist Forces during the first two years of the National Liberation Struggle, and they operated much better than the Nationalist Army. In this respect social banditry did have a revolutionary consequence since it operated as an effective force in the suppressing internal revolts and against Greek invasion, which, in turn, enabled the Nationalists to win the National Liberation War.

This alliance between the bandits and the Nationalists is not specific to Turkish history. Billingsley, who studied the bandits in China, notes that, “modern g'xerilla leaders...believed that the recruitment of traditional groups like bandits and secret societies was possible and indeed necessary. With correct training and proper leadership. their members would be thrown ints the heart of the political struggle and become a revolutionary force" $(1981$, p. 24 !). However, it is necessary to point out the fact that 
bandit bands in Turkey operated with a certain autonomy and in many cases they refused to take orders from the leaders of the Nationalist Amy. In other words the connection between the bandits and the Nationalist Army was more problematic than in the Chinese case.

The main motive for the bandits who supported the Nationalists was foreign invasion. However, interest in looting or in exercising power at the local level also motivated the bandits to ally with the National Forces and with the local militia forces who constituted part of the Nationalist Forces. Interest in exercising local power is refiected in their opposition to the formation of the regular (conventional) army by the end of 1920. In addition, the fact that many soldiers and military deserters preferred to be part of bandit bands, suggests that exercising authority at the local level was more challenging than becoming part of the regular army. In general, it can be argued that, social banditry in Turkey became more institutionalised, formalized, and political than social banditry in other peasant society.

These developments support Hobsbawm's argument that certain political conditions, such as foreign conquest, encourages 'conscious' forms of banditry and thus structures it more firmly and permanently (1969, p. 66). In case of national independence movements bandits can become part of the larger movement, and movements of national resistance to conquest may develop the characteristic interplay of bandit-guerillas and populist or millennial sectarianism. However, Hobsbawm also suggests that, there was no future for banditry since, politically, bandits were incapable of offering a real altemative for the peasants (1969. p. 88-92). This was the case in Turkey, and banditry largely ceased to 
exist with the formation of the regular army by the end of 1920 . Most of the guerilla bands were either incorporated into the Nationalist Forces or suppressed by them.

The bandit bands and military deserters who did not support the Nationalist Forces constitute a separate category annong social banditry. The bands that did not join the Nationalists continued to exercise traditional forms of banditry. This form of social banditry can further be separated into two groups. On the one hand, there was that form of banditry which was against the exercise of any form of authority, and particularly state authority. On the other hand, there were those involved in banditry for immediate personal gains, st:ch as robbers, criminals interested in raid, looting, and plunder. At times it may be difficult to separate these forms of banditry from one another since they were both reflections of peasant resistance to injustice. Thus they can be linked together as the 'traditional' form of banditry. Although large numbers of military deserters became engaged in banditry both during and after World War I, it can be argued that this shift did not cause a change in already existing bandit activities.

Consequently, the traditional form of banditry, although it was an established and a permanent form of peasant activity since the Ottoman times, cannot be regarded as political compared to the social banditry supportive of the Nationalists. Nevertheless, traditional banditry, which did not merge with the wider national movement, was still part of the state-building dynamic sin they often allied with the anti-nationalist forces, namely with the religious and ethnic groups that were against the Ankara government. However, because they were not well organized movements they remained as modest and non-revolutionary protest movements. It can be argued that, as Hobsbawm suggests, they 
remained as primitive rebels since their main aim was to preserve the traditional order of things by fighting against oppression (1959. p. 24).

Billingsley's argument supports this perspective. He argues that bandits are different from revolutionary militants in two ways. First. whereas a revolutionary force is coherently organized. bandits come together to buttress their very existence. Second. revolutionaries are aware of the need for an alternative society but the bandits are not. As Billingsley notes, "bandits see more guarantees in the world they know, and organize in accordance with its values. Fer bandits, therefore, it was usually less strenuous to join the reaction and become suppression troops, putting down those, particularly the revolutionaries. who threatened the system they had now come to represent" (1981, p. 240).

Traditional banditry was the reaction of the peasantry to oppression and injustice. However, banditry also plays a role for the local markets. Since bandits possess more cash than local peasantry, their expenditures may be important for the functioning of the local economy. They are part of the market, and contribute to the accumulation of local capital (Hobsbawm 1969, pp. 73-76). In addition to the role they played in the local market, one should not overlook the role they play in the local balance of power. Rural politics is structured in such a way that it fosters and protects the bandits, on the other hand it integrates them into the political system, particularly in places where the central state power is absent or weak (Hobsbawm 1969, p. 82).

Those bandits involved in local revolts and those involved in individual forms of banditry in Turkey reveals the fact that banditry did play a role in the local balance of power. 
Social banditry in Turkey was not restricted to a certain area or region but was part of agrarian life in almost every part of Anatolia. It was a permanent and established form of resistance against authority. Billingsley argues that, a careful look at sncial banditry can reveal important information not only about popular insurrection but also about local politics (1981, p. 238). He argues that most victims of banditry suffered more at the hands of soldiers than from the bandits themselves (1981, p. 275). In his words, "if sporadic terror had been the hallmark of certain short-lived bandits, 'total' terror was the prerogative of government" (1981, p. 277). Billingsley adds that, "a bandit's days were generally numbered by the arrival of a strong outside force, which would promptly set about making the lives of the people so unbearable that they would catch him themselves. Not even 'national' governments were above such methods when their monopoly seemed in jeopardy" (1981, p. 277). Bandits controlled the loca!, illegitimate means of power, and provided relative protection to the peasant communities.

As pointed out, social banditry and military desertion often merged with local reactions and rebellions. These movements of resistance were not representative of powerful and unified peasant movements. However, it cannot be concluded that they were movements with no clear aims and organization. hence irrelevant for understanding the dynamic of the period under investigation. As an example to this position I refer to Ergil, who argues that there were no peasant movements in Turkey during the Turkish War of Independence. Ergil claims that the local insurrections experienced in Turkey did not constitute peasant movements since the intention was not the establishment of a new political or at least a new agrarian order. In his words, 
Most of the leaders of these insurrections were members of the Anatolian lowal 'ulema' or local religious figures such as sheikhs and 'hocas' (clericals) who incited the peasants against. the Nationalist Ankara Government. These men of religion feared that the struggle between secularist-nationalist social forces and the theocratic (Ottoman) polity would end with the liquidation of the latter. They feared the loss of their traditional privileges and high status. But. because these sporadic rebellions were neither fully supported by the peasantry nor were part of a wider movement, they were repressed relatively easy (1974, p. 85).

Ergil also adds that, since these intemal reactionary rebellions did not take the form of an extended civil war, there was no breakdown of authority either at the national level or in the countryside. Thus these reactionary movements did not constitute a peasant movement (1974, p. 85).

Ergil conception of peasant movements is based on the economistic Marxist position. Although the Turkish peasants' movement was not a unified and a revolutionary political movement, it joes reveal the nature of the conflicts during the War of Liberation. In this respect it does provide valuable evidence about those involved in the process of statebuilding. At this point I find Thompson's argument on reactionary and local peasant movements very promising.

According to Thompson, the term 'riot' "can conceal what may be described as a spasmodic view of popular history. According to this view the common people can scarcely be taken as historical agents before the French Revolution. Before this period they intrude occasionally and spasmodically upon the historical canvas, in periods of sudden social disturbance" (1991, p. 185). Within this framework. Thompson looks at the ways through which custom, culture, arid reason modifies peoples behaviour. He assumes 
that this modified behaviour contributes towards more complex. culturally-mediated functions (1991 p 187).

As I discussed in Chapter Two, forms of resistance experienced in Turkey were similar to the ones experienced in pre-capitalist Europe. They were reactive, unorganized, and mostly had no clear aims. However, this does not necessarily mean that they were temporary' disturbances. As Thompson suggests 'riots' are rarely 'uncontrolled' but display what he calls a 'moral economy'. In hịs words, "it is possible to detect in almost every eighteenth-century crowd action some legitimising notion. By the notion of legitimation I mean that the men and women in the crowd were informed by the belief that they were defending traditional rights or customs; and, in general, that they were supported by the wider consensus of the community" (1991, p. 188). Popular consensus, and the traditional social norms and obligations upon which popular consensus is grounded upon. taken together, constitutes the 'moral economy' of the poor.

Within the perspective presented by Thompson, the local riots experienced in Turkey during the period of National Liberation War, cannot be taken as movements resulting merely from moments of disturbance, hence with no sociological relevance. Those involved in local revolts were the non-Turkish Muslims, Turks, and Christian minority groups. Among these the Christian minorities had clear political aims and they were fighting for their independence. The Turks who rebelled against the authorities, on the other hand. had no clear aims and they were not well organized movements. Bandit bands were involved in most of the revolts that took place during the National Liberation period which were basically 'reactionary' peasant revolts. As Billingsley argues. 
Peasant rebellions were initially 'reactions' to perceived local manifestations of a crisis affecting all of society. Banditry. as the natural response of those tirst and most affected, was the carrier of this discontent. and the vanguard of many a rural rebellion. The bandit. like the rebellious peasani. was trying to 'restore order' in many cases to a world gone mad. not to create a new and untried people's paradise. Unfortunately, there was no road back. and herein lay the tragedy (1981.p. 240).

This form of bandit-peasant resistance contributed to the strengthening of central state power. What Billingsley concludes from the Chinese case applies to the Turkish case. As he notes. "the true bandit operated outside the law but not in opposition to the system: by classifying its enemies as bandits, the new state could thus effectively reduce the seriousness of their activities" (1981, p. 240). Public safety became a major problem in Turkey especially during the National Liberation War. The problem of public safety also undermined the authority of the new Ankara government. As Billingsley notes, although bandits represent the interests of the peasant communities, when they moved beyond their local boundaries they became an enemy, whatever their origins. In his words, "in his home area the bandit identified his world, providing a model for heroism and youthful rebellion; outside its confines, spatial and emotional, he was as a dead man, an outlaw to be hunted down and killed even as the bandit outsiders protected their own" (Billingsley 1981, p. 272). In this respect banditry can become a threatening source not only against state authority but also against public safety at the local level.

The passing of the 'Law on High Treason' in April 1920, and the establishment of the 'Courts of Independence' were the measures initially taken against military desertion and social banditry since the authorities had no control over their activities. The Ankara government began its brigand hunting based on this law and executed many brigands and 
military deserters. either because they were practising banditry or because they took part in local revolts against the Nationalists.

The establishment of the extraordinary tribunals was a tuming point in the history of early Turkish political life. These mobile tribunals functioned locally and they made use of 'exceptional punishment' such as public execution. The new Turkish state fought against brigandage and military desertion in order to establish its own authority. In addition, these courts became effective in providing the needed manpower for military service, and facilitated the establishment of the regular army which further contributed to the centralization of state power. It was through the establishment of the regular army that the Turks were able to expel the Greeks from Anatolia. Through this military success the new state gained legitimacy not only among the Westem colntries but also among the Turkish population. These extraordinary courts were very much feared. They had much power over local affairs and were able to execute offenders without the approval of the Assembly. It is also claimed that much injustice was done. In this respect. local people feared execution by these courts and came to terms with the central state power, either willingly or unwillingly.

Non-Turkish Muslim resistance had far more important consequences for the building of the Turkish nation-state than the resistance of the local Turkish population. Particularly the Kurds. Circassians, and, to a lesser extent, Georgians took part in these movements of resistance against the Ankara government. Non-Turkish resistance contributed to the growth of Turkish nationalism and to the idea of forming a nation-state as the sole altemative to secure the Turkish population, which constituted the majority of the 
remaining Ottoman population. I deal with the Kurdish resistance under a separate heading since it was the most powerful one against the Ankara government. and the ant which most affected the form of the new state.

Generally, it can be argued that. non-Turkish opposition was perceived as a more serious threat to Turkish unity since it further destroyed the 'Muslim identity' that remained after the development of separatist Albanian and Arab nationalisms. These movements were ethnic in origin, and their claims contradicted the logic behind building a modem nationstate. For a nation-state assumes a society which is culturally and politically homogeneous. If the idea of building a nation-state was not yet a dr reloped idea at that time. then non-Turkish opposition did contribute to moving towards building a nationstate.

\subsubsection{Roforms and Popular Resistance}

Secularization changed the basis of the state's legitimating ideology. The institution of religion, which had been the cement of the Ottoman millet system, provided the mediating link between the local forces and the Ottoman centre. It was through religion that the local structures were linked with the Ottoman ruling class. Hence religion provided the source of political legitimacy. The split between the 'official' and 'popular' religion was essential in Ottoman society. This distinction has its roots back in the formation of the Ottoman Empire. As Mardin puts it.

[T]he Ottoman Empire was founded by a group of warrior-knights, the Gazis, who carried the burden of its expansion in its formative years. Underlying this formation were nomadic Turkic groups whose economic basis was that of the 
redistribution of spoils in potlatch-like institutions. When the Ottoman state gradually assumed the feature of an urban-centered empire, the building of centralized institutions had to rely on a system less generous in terms of redistribution. A surplus had to be taken by the central power. Thus, for many years the heirs of the Gazi tradition, who objected to this change, and the state were locked in an endemic...struggle. The Gazi team gathered around itself nomadic structures, the successors of the religious leaders of the Gazi, heterodox Islam, and the remains of the Central Asian culture. On the other side were the officials and the supporters of the state religion (1971, p. 203).

While the official religion was the religion of the upper classes. popular religion was the religion of the lower classes. The latter, the 'dervish' religion functioned as a communityreinforcing and identity-forming process among the lower classes (Mardin 1971, p. 206). The Ottoman urban dwellers always had problems in controlling the large number of nomads in Anatolia who constituted the core of the Empire. In addition the religious heterodoxy of the provinces always produced a tension between the centre and the provinces. Still further the ethnic basis of societal organization prevented the population's identification with the state.

When Ataturk replaced the official religion with the principle of laicisme, the basis of legitimation offered by Islam was destroyed. However, as discussed earlier, Turkish secularism differed from Western secularism. If in the West secularism refers to the separation of the 'church' from the 'state', in Turkey it came to mean the control of the religious institution by the state. In this sense secularism shows a peculiar characteristic in Turkey when compared both with the West and with the Muslim world.

The preservation of the state by Western-minded bureaucrats and the intelligentsia, and their thought of separating the state from Islamic institutions deepened the existence of the two different cultures. By the time the nation-state was established, the resistance 
between the center and the provinces had turned into a power struggle for the control of the state. This struggle was mainlv between the periphery. unified under the domain of religion, and the state espousing modemity, nationalism and centralization (Baykan 1990. p. 143). In this respect, republican secularism further deepened the gap between the center and the provinces and contributed to the tension between modernity and tradition.

Mardin points to the fact that in the West the process of centralization that created the modern state was successful in integrating the periphery into the centre. In his words. with the formation of nation-states, "the feudal estates...or the workers became integrated into the polity while, at the same time, obtaining some recognition of their autonomous status...These successive confrontations and co-optations had important consequences...In the Ottoman Empire before the nineteenth century these characteristics of multiple confrontation and integration seem to be missing. Rather, the maior confrontation was unidimensional, always a clash between the center and the periphery" (Mardin 1973, p. 170). This confrontation is reflected in the tradition of a strong central state.

Resistance in general, and Kurdish resistance in particular, to the secularizing reforms of the Turkish state can be approached from the perspective Tapper suggests. According to him, 'frontiers', either as 'empirical groups' or as 'conceptual categories', are key to understanding the confrontation between tribe and state. Frontiers may be territorial, cultural, social (using middlemen and chiefs), or spatial (through avoidance). He defines the spatial frontier as alienation from the ruling elite either by ideology or by deprivation of control of means of production. These frontiers, according to Tapper, are actually in the mind, and they are, in a sense all cultural frontiers (1983, p. 71). It can be argued that. 
in Turkey, all of these frontiers were present in the struggle between the central authority and the tribes.

Lnder Ottoman and Turkish governments, territorial frontiers had always existed. Each tribe inhabited a well-defined territory and had rights in well-defined pasturelands (van Bruinessen 1983, p. 373). After the Independence War territorial frontiers were more strictly defined, not only on a tribal basis but also on a national basis. Cultural frontiers, which are erected by tribes when threatened by the state or other outsiders, had also existed since the Ottoman times. Cultural frontiers, too, became more clearly defined in maintaining the 'ideology of independence' after the establishment of the Turkish state. especially for religious groups and Kurds. For example, Olson notes that, Kurdish leaders began to make propaganda against the Kemalists among the sheikhs and 'hocas' (religious teachers) in 1920. They began to wear Kurdish clothes, to speak Kurdish, and to circulate Kurdish poems among the tribes (Olson 1989, p. 27). After the hat reform those resisting the new hat law began to wear the old headgear known as 'turban' in place of the prohibited 'fez'. In this respect, these resistance acts first against the Nationalists and later against the reforms carried out by the state can be seen as taking place mainly within territorial and cultural frontiers.

Social and spatial frontiers also constituted areas of struggle. Using middlemen and chiefs as negotiators has always been an effective means of solving the tensions between tribe and state. Spatial frontiers, too, had existed under Ottoman rule. Kemalists succeeded in drawing some Kurds to their side by offering them official positions such as 
governor (kaymakam) or mayor. They also offered jobs to influential Kurds to join the nationalist movement (Olson 1989. p. 29).

Turkish nationalism did not allow spaces for the development of a variety of other political identifications. Ethnic and religious identities were rejected and were not represented at the level of national politics. The adoption of Westernism, nationalism. secularism and populism as the basic principles to be followed. in a sense. prevented the unification of the center and the periphery. In this respect. Turkish nationalism differs from Vest European bourgeois nationalisms which was accompanied by liberalism. rationalism and positivism and which brought about the unity of culture and polity. Turkish nationalism provided no autonomy to the civil society, to the individual, and to the market forces. For these reasons, as Gole argues, it is against liberalism. pluralism. and differentiation (1991, p. 130).

Those movements of resistance against Kemalist reforms can be examined within the context of Westernization. It can be argued that Kemalism fostered further segmentation in Turkish society as a result of the process of We stemization of traditional values. As Mardin notes, while the lower classes supported the War of Independence and resisted the invaders, the civil aims of the revolutionaries were nut supported by popular demands (1971, p. 198, 199).

Turkish nationalism replacing the role of religion was not able to produce a total uniformity among the Turkish population although it has been the ruling ideology since the foundation of the republic. As suggested by Gellner, modem nationalism is a process 
of constructing a 'nation', which is a culturally homogeneous society, through forced assimilation (Gellner 1983). This process inevitably initiates some form of discontent among the popular classes. In the Turkish case the tension between 'high' and 'popular' culture was further deepened by various notions of the 'West' which intervened between the already existing cleavages from Ottoman times. As Keyder notes,

The reaction to official nationalism, which intended to supplant all that was traditional, required at least an implicit critique of modernity in order to ideologically ground its malaise. Such a critique first emerged as an aspect of discontent with modemisation-from-above and found its expression in populist political opposition. A confrontation evolved which was presented by the Republicans as one between modernity and tradition, but which in fact contained a multiplicity of dimensions, including the defense of local culture against a transformed (hence alien) and authoritarian great culture. the upholding of mass values against elitism. and the protection of religious laissez-faire against militant secularism (1993, pp. 24-25).

\subsubsection{Kurdish Nationalism}

The development of Kurdish nationalism played a decisive role in structuring the form of the Turkish state. The impact of Kurdish nationalism on the state-building process in Turkey can be analyzed at two different levels. It can be argued that Kurdish resistance movements that took place under the Ottoman rule had a strong impact on the formation of Turkish nationalism. The Kurdish resistance movements and revolts that took place during the Turkish War of Independence can be regarded as a continuation of this first period. The second phase of Kurdish opposition, beginning with the Sheikh Sait Revolt, was based on nationalistic claims rather than the ethnic ones made by previous phase of Kurdish opposition. Consequently, it played a major role in shaping the form of the 
Turkish state. The abolition of the caliphate was the turning point in the emergence of nationalist-inspired Kurdish revolts.

The conflict between the Armenians and the Kurds also played a role in the development of Kurdish nationalism.

The concept of the 'nation' as we know it in Europe was foreign to the Middle East. The only solidarity group wider than the family or tribe that is recognized in Islamic doctrine is the 'umma', the community of Muslims...More foreign even than the concept of the nation was that of the nation-state. All Middle Eastern states were multi-ethnic, while several peoples. such as the Kurds and the Armenians...were represented in more than one state. Another characteristic of the Middle East was that often more than one ethnic group inhabited the same territory. Ethnic groups all had their own occupational specializations, and depended on each other to a certain extent. Thus, the areas of settlement of Kurds and Armenians largely coincided. Cynical as this may sound, it was the Armenian massacres that made a Kurdish state feasible (Van Bruinessen 1992, pp. 268269).

It is important to note that Kurdish nationalism cannot be analyzed in isolation from the tribal basis of the Kurdish population. As Gellner suggests, the tribe is an alternative to the state. Tribalism, which is part of Middle Eastern societies, is a form of rural selfadministration and it contradicts the non-tribal state. As he writes, "the tribal mechanisms which evolve to evade the arm of the state seem paradoxically also to fit the populations involved in it to create a new state, and sometimes to build a micro-state of their own" (1983A, p. 445). Following Gellner's perspective it can be argued that the conflict between Kurdish tribes and the Ottoman government had eventually given rise to Kurdish nationalism with a much more determined new Turkish state to establish its authority over the Kurdish territory as the basis for securing territorial unity and order in Anatolia. In Turkey, state intervention in tribal life did not mean de-tribalisation, and tribal 
organization that is now found in Turkish Kurdistan is the result of indirect state rule which was and still is informally practised (van Bruinessen 1983, p. 372).

Despite the general conflict between the state and the tribes, not all tribes experience conflict with the state authority. As I pointed out in Chapter Four, the Kurdish population never acted in a unified way in their relation to the central authority. This can be explained by Tapper's separation between the types of tribal leadership. He argues that there are two contrasting types of tribal leadership, namely the 'brigand' and the 'chief. In places where state authority is weak and when the tribe rejects its authority, the tribal leader becomes a 'brigand'. In contrast to the first, when the tribe recognizes the government, the tribal leader becomes a 'chief. A chief with government support can maintain his authority more easily than a brigand. As Tapper claims, "a chief has duties to both government and followers, and his position is close to that of a feudal lord. Typically he collects tax and military levies, and maintains order for the government, while for his followers he conducts extemal political relations, adjudicates disputes, and (for nomads) allocates pastures and co-ordinates migrations" (1983, p. 56). These two types of leadership are ideal types; in reality they may coincide with one another. As van Bruinessen notes, 'brigand' and 'chief' are not necessarily two different types but they are complementary 'aspects' of the 'ideal' chieftain (1983, pp. 374-375).

Tapper's distinction between these two forms of tribal leadership may be taken as the basis for understanding the changing tribal relationship with the state. Both forms of leadership were existent in Turkey although the balance of these two forms of leadership frequently changed. Those tribal leaders who supported the nationalists and those who opposed 
them practised one of these two forms of tribal leadership. While the Turkish state 'recognized' those tribal leaders in exchange for promises of loyalty. it declared the rest as 'brigands' who refused the authority of the central powers.

Besides the revolts against the central authority, Kurds mostly resisted by attacking Turkish ammunition shipments and depots, police and gendarmerie stations. In addition. capturing local government buildings. and murdering military or government officials were common forms of resistance to state authority. This form of resistance can be regarded as symbolic since it was a way of refusing the power of the state by killing its representatives. However, after the Independence War, the Kurds not only murdered Turkish government officials but did attempt to capture towns or villages on many different occasions. For example, after the signing of the Treaty of Sevres, the Kurds demanded autonomy (Kocgiri Revolt) in the region of Diyarbekir. Elazig. Van, and Bitlis. They backed up their demands by using the Treaty of Sevres to increase their autonomy within Anatolia (Olson 1989, p. 33). This region was held by the Kurds where they had raised the Kurdish flag. The Nationalists negotiated with the Kurdish leaders. Important Kurdish leaders were appointed to the Assembly by Mustafa Kemal.

In general, the Kurds on many occasions captured towns and villages. Their movements were either suppressed by the national troops or solved by negotiating with the leaders of the Kurdish movement. However, Kurdish resistance became more organized in the following years, demanding not only autonomy but their independence form the Turkish state. In response to these demands the Turkish government took stronger measures against the Kurds. Olson notes that, the Kocgiri Revolt as the first serious revolt against 
the Nationalists, "did affect the policy of the government in Ankara and seems to have contributed to the first effort by the new nationalist government to deal with the 'Kurdish question"' (1989,p 38).

Tapper argues that, the Kurdish emirates under the leadership of Ottoman, Safavid, and Qujar states, took the form of vassal or 'secondary' states with established hierarchies of wealth and authority. He also notes that, notions of tribal autonomy, democracy and egalitarianism were not well developed notions among the Kurdish tribes (1983, p. 60). Within this framework. Armenian nationalism did have an impact on the development of Kurdish nationalism. The age-old tension between the Kurdish tribes and the Ottoman state gave way to a new form of Kurdish resistance which was a political movement based on nationalistic claims. The tribal and ethnic basis of Kurdish opposition to the state gained a new momentum not only with growing Armenian nationalism but also with the secularizing policies of the new Turkish state. In this respect, the Sheikh Sait Revolt marks the beginning of a new era of politically organised Kurdish resistance movement. Efforts to assimilate the Kurds further contributed to the growth of Kurdish nationalism.

In Olson's view, "the Kurdistan question was tied to the question of the caliphate and some of the deputies' opposition to the Kemalists. Some obviously saw the Kurdish support for the caliphate as additional leverage against Mustafa Kemal, to whom opposition was growing in the spring of $1922^{\prime \prime}(1989$, p. 40). Many believed that forceful methods should be avoided in dealing with the Kurdish problem. However, the Kundish deputies in the parliament, although supporting the Kemalists, were seeking more than just administrative autonomy as promised. As Olson claims, those who proposed liberal 
policies to grant greater authority for the Kurds in defined administrative areas. were the deputies and not the close advisers of Mustafa Kemal. who determined policy. In this respect. the Turks tried to keep the support of the Kurds during the most challenging times of the early Turkish state. In Olson's words. the Turks, "did not remotely consider independence or even autonomy in any meaningful sense of that term...Kurdish nationalist activity experienced a resurgence after the Treaty of Lausanne. which was to lead directly to the outbreak of the Sheikh Said rebellion. After the treaty, which made no mention of an independent Kurdistan or Armenia, the Kurds had no choice but to attempt to achieve greater rights through the use of armed force" (1989, p. 41).

Tapper suggests that, the role of the state and tribal reactions to state policies are the key factors in explaining change, and that tribe and state form a single system.

The major variable is the influence of the state, both as an external force and as an idea in opposition to the idea of tribe. The essence of the latter is indeed kinship and egalitarianism (the basis of a segmentary lineage system), while that of the former is territoriality (the basis of communities and opposed blocs) and central authority (the basis of patronage). It is in these terms that we can understand both variation in actual tribal forms and changes that have occurred, whether we adopt a cyclical (oscillation) model of change or acknowledge the apparently irreversible (evolutionary) changes that have now taken place in the transition from tribe to state (Tapper 1983, p. 70).

It can be argued that this firm link between the state and tribe in Turkey, although constituting a s, stem based on contradiction and opposition. formed the basis of a tradition held by the officials which regards both the Kurds and Turks as part of a single system. In Tapper's words, "some states go so far as to deny the existence of any intemal ethnic differentiation, but most have to recognise 'minorities', which may be 'tribal' in 
culture or organisation though today they are often termed 'ethnic' or 'regional' groups or 'nationalities'"' (1983, p. 67).

The Turkish state clearly followed the first path and denied Kurdish demands for independence or autonomy. This denial found further support with the project to form a modern nation-state which aimed at securing the territorial unity of Anatolia. As pointed out earlier, the signing of the Treaty of Sevres between the Ottomans and the Allies. played a major role in the Kemalists' rejection of Kurdish claims for independence. As van Bruinessen notes, during World War I. pan-Islamic sentiment was stronger than Kurdish national feeling. and "there were no serious attempts to separate Kurdish territory from the Ottoman Empire. After the Ottoman defeat, however, nationalism spread very rapidly all across Kurdistan...As an independent Kurdish state became feasible, many sheykhs and tribal chieftains suddenly became nationalists and revolted" (1983, p. 379). Under these conditions, the formation of a modern nation-state eventually appeared as the only viable project to be followed for an independent Turkey.

With reference to Kurdish nationalism. Tapper argues that, "in many cases, such as the Pathans, Kurds, Baluches and Turkmens, states and empires have not only created tribes as political groups, but they have then prevented them from developing their own political identities as nation-states" (1983, p. 75). In this respect, the way the central authorities in Turkey have approached the Kurdish population is not unique to Turkey. State refusal of ethnic-tribal claims for autonomy can be regarded as part of a wider dynamic which is based on the conflict between the central state and the tribe. 


\subsubsection{Constitutional Developments}

Finally. I discuss the history of constitutional movements which are part of the statebuilding dynamic. I find the perspective provided by Dearlove very useful with regard to the role of constitutions in discussing the link between the state and society. Dearlove claims that, state-centric theories adopt a 'top-down' perspective that starts with the state and that policy is imposed upon the society from above. In this perspective, social classes and groups appear as very weak in determining the policies of the state. Most importantly. state policy is not seen primarily as a reaction to societal pressure (1989. pp. 528-529).

Based on this argument, Dearlove suggests that, constitutional study offers much for understanding the state. As he argues, constitutional theory should be regarded as part of state theory.

because it deals with the structure of relationships 'within' the state - on the way it hangs together - and on the relationship 'between' the state and the other organizations and associations in society...Constitutional theory offers us a concrete way of bringing the totality of the state back in to consideration in a way which respects the integrity and uniqueness of particular states and their place in history (1989. p. 533).

It is in this theoretical framework that a discussion of the history of constitutions in late Ottoman society and in early Republican Turkey is useful. The transformative process that turned the multi-ethnic and Islamic Ottoman society into a modern and secular Turkish nation-state is reflected at the level of constitutional developments. The Republican constitution was the outcome of internal pressures on the one hand, and on the other hand it did transform the society. As Dearlove stresses, the constitution is not only a force that is almost 'outside' politics which constraints and shapes politics, but also it is 'in' 
politics sirce it can be the focal point of major conflicts and is subject to change (1989, p. 534).

I now turn to constitutional movements in Turkey. I exclude those constitutional movements that took place in the first half of the nineteenth century and focus on later developments.

The Ottoman state experienced constitutionalism twice, first in 1876as a result of the Young Ottomans' movement (which was the first experiment in constitutional government in the Islamic world), and later in 1908 as a result of the Young Turk Revolution. Both were shor lived experiences, and there was no established tradition of constitutional government in the Ottoman society. Berkes argues that, Ottoman constitutional movements were not the result of a direct Western impact. On the contrary, during the second half of the nineteenth century, when non-Muslim millets gained material and communal successes, the Turks came to question their existence. In Berkes's words, "at this stage, the questioners found in thcir Islamic heritage the only basis for unity. The Ottoman state would have to be an Islamic state in order to represent that unity. It was because of this logic that the earliest manifestations of the constitutional movement had religious, anti-Westem, and anti-Tanzimat colourings, in addition to ambiguity in basis and aims" (1964, p. 202).

As Berkes points out, the 1876 Constitution was not framed by representatives of the people. It was bound by the Sultan's will, and "the political doctrine upon which it was made was not the idea that sovereignty lay in the people, but the idea that sovereignty still 
belonged to God and to His earthly vice-regent. the Padisah; His law was the Seriat [Sharia] of which the Constitution was only a part" (1964. p. 246). The ruler had the right to dismiss the National Assembly and prorogue the constitution. In addition. the constitution rejected the idea of a secular state and affirmed the Islamic aspect of the stilte. The legislative, executive. and judicial powers were not separated from one another. The government. like the Assembly, was subject to the ruler's free will, and both the appointment and dismissal of its members was under the responsibility of the ruler. This constitution, as Berkes argues. "was ultimately the foundation for the Hamidian regime. No more telling example can be found in history of the inevitable consequences of ideologies that are inherently inconsistent and contradictory" (1964, p. 348).

In the 1876 Constitution Christians, Jews. Turks, and Arabs were all represented according to their proportion within a constituency. This principle of Ottomanism did not last long, and Abdulhamit prorogued the parliament in 1878 on the grounds that military. diplomatic, and financial problems forced him to do so. Tanor argues that, the first parliament ever established in the region following the 1876 Constitution. was not a real parliamentary system in the technical sense but it was a step towards parliamentary life. As he notes the first parliament existed on paper for two years but in effect it operated for only five months (Tanor 1990, p. 139). Following the prorogation of the constitution, the leaders of the constitutional movement were persecuted. Some were sent to exile. while others were sentenced to death or to imprisonment. Those in exile became the leaders of the Young Turk movement, which was basically a movement against the Hamidian rule. The Young Turks aimed at restoring the constitutional rule. 
Berkes uses the term 'Young Turks' to refer to those who opposed the Hamidian regime 'politically'. Although there were ideological divisions among the Young Turks, as I discussed in Chapter Three, all were opposed to the existing absolutist regime (Berkes 1964. p. 305). In this respect, the Young Turk movement was not yet a nationalist movement but it did eventually become one. For the Turks did not recognize themselves as constituting a 'millet' like other 'millets' of the Empire. The Turks saw themselves as members of a Muslim state but nothing else.

The 1908 Revolution. which was the restoration of the 1876 Constitution, did not bring about any constitutional changes to solve the tensions between Westernists. Islamists, and Turkists. This second period of constitutional monarchy lasted until 1918 when the issembly was abolished by the sultan without calling new elections. During this period no demand was made to separate the state from religion at the constitutional level because it was still a very undeveloped idea at that time. In addition the Islamists were still a powerful block defending the thesis that the constitutional regime was in accordance with the Sharia. As Berkes notes, "what the Islamist writers understood as constitutional reform was to put the state into the service of religion, that is to use the government as a power to force the people to abide by the Seriat [Shaia]. The state was conceived simply as the means of promoting the Seriat. Not orly was there no place for the conception of a secular state in the thinking of the Islamists, but the very idea of democracy was rejected by their best minds" (1964, p. 370).

There were many who were against the restoration of the constitution and against the modifications to limit the powers of the ruler. Berkes quotes from Said Halim Pasha, who 
best represented the Islamic view with regard to constitutional matters. As Said Halim

Pasha wrote in 1911.

Constitutionalism is one of the results of the erroneous idea of achieving reform by making laws drawn from Europe. European constitutionalism will not work here...In Islamic society, the personal or functional prerogatives of a ruler do not mean absolutism, though they may mean it in the West. The tyrannies of the West were made in the name of religion and church. This is not so with us. The internal class struggles of Western society do not exist in Islam. Islamic society progressed so long as the principles of Islam were applied. Democracy, which has been found as a remedy to the inequalities inherent in Western society, therefore, is entirely irrelevant to us...Ottoman political unity is not based on nationality as it is in the West, but rather on Islamic unity and brotherhood (in Berkes 1964, p. 372).

The struggle between the Westemists and Islamists over the form of the state was the main controversy during the Young Turk rule. The Islamists regarded the Sharia as ine constitution of the Islamic polity, and they demanded 'legislation' to the extent that it enforced the provisions of the Sharia. The Westernists, on the other hand, were fighting for a liberal democratic state through separating the state from the domain of religion. The most powerful rivals of the Islamist fraction became the Turkists over time. The ideas such as 'Turkish government', 'Turkish army', 'Turkish territories', and 'Turkish monarch', as suggested by the Turkists, were regarded as breaking down Ottoman elements. Berkes points out that, “although Islamist opposition to nationalism broke out only in 1913, even in 1912, during the Balkan Wars, the Islamist organs showed their dislike for the appearance among the Turks of words such as 'Turk'. It sounds strange, of course, but it was only at about this time that those who were called Turk by everyone except themselves began to use this name, and then not universally or officially. Islamists scolded such innovations, and denounced 'kavmiyet' (nationalism) as blasphemy" (1964, p. 373). 
The tension between these trends of thought did not cr':re to an end during the Young Turk nule. The state remained an Islamic state but many steps were taken to reform the religious institutions, alongside with reforms regarding family life and education.

However, with the Young Turk rule, some important constitutional changes did take place. As Lewis stresses, although there was no time for a systematic revision of the whole text of the constitution, a series of amendments were produced that either modified or replaced some of the articles in the old constitution. All these amendments, which aimed at strengthening the parliament and weakening the throne, amounted to a major constitutional change. The power of both the Sultan and the Grand Vezir were reduced, and the sovereignty of parliament was affirmed (1968, p. 363). However, the new Sultan, Mehmed V, was the collaborator of the Unionists, and the Unionists submitted many proposals to strengthen the power of the Sultan as a means of protecting their regime. Following these developments, the Sultan "was now able to convene, prorogue, prolong, and dismiss parliament almost at his discretion" (Lewis 1968, p. 364).

After the assembly was abolished in 1918 no new parliament was formed until 1920. However, the new assembly prorogued itself in two months in response to the arrest of some of its members by the Allied occupation forces. With the opening of the Grand National Assembly in Ankara in 1920 the country tumed to parliamentary life once again.

The new Kemalist regime was the first experiment in a constitutional and republican forms of government in the Islamic world. At the beginning, although a commitment to the Sultanate-Caliphate was avoided, "the regime established neither Westem 
parliamentarianism nor communist sovietism, neither an Islamic state nor a corporative system of professional representation" (Berkes 1964, p. 446). The 'Law of Fundamental Organizations', which passed the Assembly in 1921. was in fact the provisional constitution of new Turkey. The law declared the sovereignty of the nation. and that the Grand National Assembly was the only representative of the people (Lewis 1968. p. 367). This was a revolutionary parliament; it kept a monopoly not only of the legislature, executive and judiciary but also the authorization to charter its own constitution. During 1920-1922 the Assembly strictly controlled the executive by choosing it from among its own members (Tanor 1990, pp. 142-143).

With the abolition of the Sultanate in 1922 and with the proclamation of the Republic 1923, came the new Turkish constitution of 1924 which remained in force until 1960.

The Ottoman constitutional experiment can be regarded as a struggle over retaining the Islamic character of the Ottoman state as a solution to the Empire's internal problems. Constitutionalism was regarded as means to prevent the dissolution of the separate 'millets' of the Ottoman society. It can be argued that, after the Turkish War of Independence ended, the constitutional sphere became the field of struggle for competing political identities, Islam and Westernism still being the two dominant and conflicting sources for political identities. Although both the 1921 and 1924 Constitution retained Islam as the state religion, Nationalists succeded in secularizing the state, and separating it from the domain of religion. Religious education was prohibited, European civil and penal code was adopted, pious foundations were nationalised, and the power of the 'ulema' 
(clergy) was eliminated. Finally, in 1928 secularism became legal when Islam as the religion of the state was removed from the constitution.

With regard to constitutional legislation and right of amendment, Ottoman parliaments always had very limited power. However, as Tanor argues, despite the weaknesses of Ottoman parliamentary assemblies, they continually criticised the government on matters of foreign policy, on the conduct of war efforts, and on issues affecting rights and freedoms. In this respect, even this modest parliamentary system was able to produce anxiety among the conservative circles of the Ottoman society (Tanor 1990, p. 142).

The Turkish Grand National Assembly was an independent parliament representing the Turkish nation. The National Assembly, as Tanor notes.

kept a monopoly not only of the legislature, executive and judiciary but, above all, the authorization to charter its own constitution (evidenced in the 1921 constitution which was its work). In this period (1920-1922), parliamentary supremacy and the principle of unity of powers was widely respected. The assembly closely controlled the executive which it chose from among its own members and even in the most critical periods of the national War of Independence was extremely cautious in granting extraordinary powers to the commander-in-chief (1990, pp. 142-143).

The Turkish National Assembly played a major role during the War of Independence. The fact that the Independence War was organized and won by a system of assembly government made the assembly the central institution of the post-liberation polity (Tanor 1990, p. 143). This historic role played by the assembly gave it the power to transform the link between the parliament and the former citizens of the Ottoman society on new grounds. In the eyes of the majority the Turkish Assembly represented not only the continuation of legality, but also the most powerful institution capable of taking radical 
steps towards establishing this new legality on firm grounds. Based on this power the Assembly was capable of transforming the existent social and cultural symbols such as headgear, dress. the alphabet. and the calender.

The new Turkish constitution (1924) did not emerge as the result of recognizing the demands made by various groups seeking recognition at the constitutional level as in democratic political systems. On the contrary, it can be argued that, it emerged as a reaction to internal pressures, namely as a reaction to religious and ethnic groups. In addition, in the aftermath of the Liberation War, the National Assembly proved to be the most powerful institution with the power to strengthen the institutional basis of the new regime. The constitution was in accordance with the new state which was a modern nation-state.

In this respect, the parliamentary and constitutional struggles in young Turkey were detached from the aspirations of new cultural and political groups who experienced a change in conceptions of community life. This becomes more clear with respect to the rights of non-Muslim and non-Turkish minority groups. The constitution of the Turkish Republic accorded complete equality to all citizens. However, as Lewis writes, "even on the official side, in the structure and policies of the state, there were signs that, despite secularism and nationalism, the older idea that Muslim equals Turk and non-Muslim equals non-Turk persisted. In some respects the participation of non-Muslims in the public life of Turkey actually decreased after the establishment of the Republic, although their legal status on paper was higher than ever before" (1968. pp. 356-357). 
With regard to the parliamentary life that emerged out of the period of National Liberation War, Tanor claims that,

it is still noteworthy that the second session of the assembly, which prepared and adopted the 1924 constitution, did not in the first draft give the President of the Republic the right to dissolve the assembly, nor did it allow him to veto laws or command the armed forces. Similarly, it is worth remarking that all the Kemalist reforms which were intended to change the social, political and cultural structure of the country were either legislated by the assembly or the result of decisions taken by it. Although it would be incorrect to suggest that this procedure represented anything other than formal ratification. it is nevertheless a notable indication of the importance given to the legitimatory power of law and to a perception of legality and of the role of the parliament. This is an institutional and political residue of the period of the liberation (1990, p. 143).

In general, Ottoman experiments in constitutionalism were responses to external pressures, and the parliamentary governments established by the Ottomans were detached from the society (Tanor 1990, p. 144). The Assembly formed by the Nationalists in 1920 had stronger roots in the society since it was the outcome of internal conflicts on the one hand, and of the Independence War on the other. In other words, the new parliament and constitution was in accord with the newly emergent nation-state. In this context, it is necessary to stress that, parliament has become firmly institutionalized in Turkey. As Tanor points out,

Between 1920-1980, the legistature was the sovereign political body. Whereas in Westem Europe. parliamentary government developed incrementally through the erosion of the power of the executive (the monarchy), in the Turkey of the 1920s all government, including the power of the executive, was suddenly concentrated in the assembly. In terms of constitutional law, it is only very recently that an executive body has managed to extricate its authority and win gradual independence from the legislature. Even in the 1961 constitution, where the separation of powers is mentioned for the first time. the legislature is referred to as the 'fundamental' authority whereas executive authority is considered to be 'derived' (1990. p. 146). 
In general the 1924 Constitution gave the Assembly the monopoly to exercise sovereignty. This situation changed with the 1961 Constitution. The Assembly was no longer the supreme institution. As a result, the executive and the judiciary became more powerful in the exercise of sovereignty. As Tanor emphasizes. with the power given to the judiciary to interpret the law, "the 'Rousseauist' and 'Majoritarian' understanding of democracy current in the 1920 s came to an end" (1990. p. 148). The supremacy of the legislature in the 1924 Constitution no longer existed in the following constitutions.

To conclude this chapter one last point should be mentioned. 'Populism' and the idea of the 'sovereignty of the people' were the basic constitutional principles. This principle is rooted in economic matters as well. The Turkish Revolution was not based on a clear economic program. For example, the principle of etatiom emerged after the completion of the revolution. The new government of the republic, similar to the old empire. ignored economic matters and continued the tradition of protecting the centralized state as their primary aim. Economic self-sufficiency as a developmental program was integrated into the Kemalist principles as a protection against the West. Also the Soviet Union with its state-planned economy was seen as an altemative to the liberal-capitalist economies of the West. This suggests that the ideology of populism, having its roots in the 1908 Constitutional regime of the Young Turks, served as a rejection of class struggle denoting the superiority of the state over the population.

The ideology of populism also was a protection against ethnic tensions stemming from the past. As van Bruinessen points out, "populism became the ideological justification for a policy of nation-building that denied the existence of a separate Kurdish (or Laz. 
Circassian, etc.) culture, and made the Kurds into Turks by decree" (1992. p. 274). To summarize. Westemization, the assimilationist ideology, and the populist outlook of Kemalism appear as the basic features of Turkish nationalism. Turkish nationalism, together with secularism and populism became the principle on which the nation-state was built.

As Dearlove suggests, constitutional theory specifies the 'proper' constitutional relationships between the institutions that make up the state. This, in tum. provides the location of state authority. As he claims, "when we attend to the significance of constitutional theory - to the 'interpretation' of laws, customs, and conventions - we are getting to grips with the way in which a system of rule provides rules 'and' resources and so both constrains 'and' enables the capacity of institutions and the behaviour of individuals occupying key positions within the state" (1989, p. 534).

With the building of the Turkish nation-state radical changes took place in rules, relationships, and location of authority, which were all reflected in the Republican constitution. Most important of all, secular education replaced religious education. In addition, the Onoman language, which was a combination of Turkish. Arabic and Persian words, was rejected and Turkish became the national language of the country. Turkish was standardized in the following years. Moreover, those traditional rules applying to family life. personal relations, and dress were all transformed through constitutional changes. 
Although at this point state policies, which were reflected at the level of constitution. appear as external to those who are subject to state rule. these policies were the outcome of specific historical circumstances. In other words, the building of a modem nation-state necessarily rested on changes in location of authority and power. The building of a nation-state was the only feasible project to be followed considering a country that had to fight against foreign invasion and against internal pressure from various cultural, ethnic. and religious groups. 


\section{CHAPTER 6 CONCLUSIONS}

As argued in this study the formation of the Turkish nation-state cannot adequately be conceptualized as the inevitable outcome of the process of industrialization or modernization. When analyzing the formation of the modern Turkish state, to focus on various movements of resistance rather than formal political opposition illuminates the exercise of state power on the one hand, and the impect of resistance on the process of state-formation on the other hand. The exercise of state power is reflected through the forms of resistance that developed against it. Considering the resistance side of any relation of domination makes it possible to grasp the ideological and cultural dimension of state-building.

The absence of or the silence about resistance in the literature on Turkish state-formation has influenced the conceptualizations of the Turkish nation-state. Regarding the state as 
an institutional entity reflecting the relations between various groups within the society. it is possible to argue that the movements of resistance that took place in Turkey influenced not only the process of state-formation, but also the development of various state policies. Consequently without considering the various forms of resistance provoked by the state. and without considering the impact of resistance on the process of state-building it becomes difficult to conceptualize the state as reflecting various power relations within the society. When the state is regarded as an institution that stands above society then the analysis of nation-state building focuses only on the consequences of modemization,industrialization, and the ideology of nationalism for the process of stateformation. What follows from this framework is that, either economic classes or the bureaucrats, or the dominant political parties, appear as the key actors of the statebuilding process. Gulalp, in his critique of the 'modemization' version of OnomanTurkish history, argues that the modemization perspective is an ahistorical framework since "everything appears as an outcome of the leaders' 'conscious choices' and 'deliberate attempts ${ }^{100}$ (1994, p. 156).

This study, on the contrary, has focused on the process of itate-building as a cultural and ideological process rather than conceptualizing it as only seiting up new institutions. In this respect, it focused on various forms of resistance that reve $d$ the movements of the people in the Turkish Revolution rather than the movements of economic classes or occupational groups.

With regands to forms of resistance, not all responses to state-formation can be classified as 'for' or 'against' state-formation since there has been some contradictory responses and 
reactions that do not fit into one of these two categories. For example. the reactions of some bandit or guerilla leaders against the formation of the regular army, who had supported the nationalists since the beginning of the revolutionary movement, is a response that is neither 'consent' nor 'resistance' to state-formation. In this respect, I focused on resistance as a broad concept that includes any type of response or reaction during the building of the new state.

The formation of the Turkish nation-state shared features with the West European statebuilding experience. In response to the claims made by various ethnic, religious, and cultural groups, the building of the Turkish nation-state was the result of a deliberate process which was based on the European model. Consequently, besides the establishment of a secular modern state, a culturally and linguistically homogeneous society was created as the result of the same process. However. as I discussed in Chapter Two, section II.2.5, this process of homogenization can be regarded as incomplete since it was more effective in urban areas. As McCarthy points out,

One of the reasons that Anatolian Muslims were more receptive to reform after the wars was that they were more urbenized...A good indication of increased Muslim urbanism can be gained by comparison of the percentage of total population of urban Muslims in major cities. Although city size was no greater in the early Republic than it had been in the Empire, the percentage of urban Muslims in the population of Turkey increased because more of the urban dwellers were Muslims and the total population had decreased. due to war deaths... Of all the migrants, it was those who migrated to the cities that most assuredly became constituents of reform. They were more likely to become literate and educated...They were, of course. also more likely to work in non-agricultural industries and innovative occupations than were rural dwellers. All Turkish migrants experienced to one degree or another the psychological changes necessary for the acceptance of reform (1983. pp. 142-143). 
Turkish nationalism and the establishment of the Turkish nation-state was a response (1) internal pressures rather than a consequence of the spread of Westem nationalism. Western nationalism was more influential in motivating the minorities such as the Armenians. and both state policies and forms of resistance provoked by the state-makers reveal the fact that the state-builders considered the Western model of nation-state as the only viable model to be followed in overcoming the problems they faced in the aftermath of World War I. However. Westernization as one of the influential social and political trends since the Ottoman times did provide the grounds for a break from the traditional order during the transformative process from the Otoman Empire to the Turkish Republic.

Although Westemization and modemization did play a role in the development of Turkısh nationalism, many power groups with no clear class base or an ideology were involved in the making of the new state. Most important of these were the movements of various nonMuslim and non-Turkish ethnic groups which gave the Nationalists the impetus to homogenize the society - both culturally and linguistically - as an essential step in securing the territorial integrity of Anatolia. In this respect, both ethnicity and regionalism appear as a major dynamic in conceptualizing the building of the Turkish nation-state. Moreover, religious cleavages among the Muslim population which were often linked to the divisions among the non-Turkish Muslim population such as the Kurds, constituted another major dynamic among alternative power groups that claimed authority at the national level. In this respect. Turkish nationalism, ethnicity, and Islam all 
served as competing sources for the formation of new identities which in turn influenced the nature and the form of the new state. McCarthy's argument supports this point.

Turks fought Greeks in the West and fought Armenians and Russians in the East. Turks were forced to think of themselves as Turks and to fight as Turks. even if they had not previously thought such identification to be important. Those who had considered themselves to be Ottomans found that no such identity existed in times of inter-communal warfare. Those who had primarily identified themselves as Muslims. probably the majority, found that their brother Muslim Kurds raided them and their brother Muslim Arabs revolted against their rule. In short. Turks were forced by circumstances of war to consider themselves as Turks and as par of a Turkish nation. This was the base upon which the Turkish nationalism of the Republic was built (1983. p. 146).

The treatment of ethnicity appears as a problem in the literature on both state-formation and nation-formation. As I discussed in Chapter Two, section II.2.4, language and kin ties can become the sources for mythologizing past histories. This makes ties of ethnicity distinctive compared to other loyalties such as economic class since it can easily intersect with various other ideological sources - such as religion or regional and local histories in the construction of present realities. In this respect. ethnicity can form the basis of cumpeting political or territorial claims as was the case in Turkey.

Greeks of Turkey, Armenians, and the Kurds became a real threat to the Nationalists during the formative ycars of the Turkish state. Stemming from ties of ethnicity, they all claimed a national status and fought for their own independent states against Turkish domination. This provided the grounds for cleavages that seriously challenged the establishment of the central authority by the Nationalists. In this sense, they moved from the status of an ethnic group tc a natio. ral group, and took part in the wider nationalist movement. It is important to note that not all ethnic groups made nationalist claims. For 
example the Circassians and the Albanians. although they took part in certain resistance movements. remained as an ethnic group rather than seeking to organize themselves as a nation.

The West-European process of state-building. although it was carried out by the bourgeoisie, involved ethnic conflicts and struggles which constituted tensions other than the ones stemming from class struggle. The main point is that ethnicity became more and more important in the building of new states. Whereas states in Western Europe were made by a minority class, late nineteenth and twentieth century state-building involved the participation of wider populations, and hence provided more space to ethnic and religious movements. The establishment of the Turkish nation-state is no exception to this more recent form of state-building. However, as I argued above, the Turkish nation-state can be grouped among the classical nations-states that were established in Western Europe since it was based on the West European model of nation-state building.

Another point that needs to be emphasized is related to the concept 'state-building' itself. It is necessary to distinguish between 'state-formation' and other types of state action. While state-formation in Turkey was the result of conscious and intentional actions, it was at the same time the unintended consequence of another broader project which was to save Anatolia from foreign invasion. Such a project required local participation and coordination between distant regions which, in tum. provoked resistance from different ethnic groups and minorities as well as the peasants themselves. The unintended result of the efforts made in Turkey to attain political and social stability was the extension of state mlicing to $r$ any of the distant and inaccessible regions of Anatolia. Moreover, the state 
became more rational, centralized, and authoritative in response to the opposition that it faced at the domestic level. In this respect, both foreign invasion and domestic disturbances had serious consequences for the building of the new Turkish state.

In a similar way Westernization, too, had unintended consequences for the building of the state. Many of the reforms that took place after the proclamation of the republic required state intervention and coordination between regions which furth:r contributed to the formation of a rational and centralized state. Thus although not all state actions form pan of the state-building process, in the Turkish case most had a strong influence on the establishment of the centralized modern nation-state.

Major theoretical traditions and models that have been used have their weaknesses in explaining not only European state-building experience but also in explaining the countries other than West-European countries such as Turkey. To look at state-building through local politics can be taken as a recent trend which considers cultural values and processes as an essential part of the state-building dynamic. The cultural field is where new identities are formed and shaped, and in times of social transformation these competing identities can become part of broader political conflicts and movements which does influence the direction of state-building.

To establish a new society can often become a requirement in the process of making a new state. The emphasis on building a new society was fundamental for the Turkish revolutionaries. As Sunar points out, the idea of society was understood not only as the ultimate source of values, but also as a private sphere carved out by legal guarantees. In 
Sunar's words. "according to the revolutionary formula. everything was society's creation. or more accurately. the creation of the collectivity of the people defined as the Turkish nation. This was a truly revolutionary act. a radical break with the Ottoman past: the Turkish Revolution changed not only values but their very source" (1974. pp. 60-61). In this respect, the building of a new state brought about the establishment of a new society. and this process cannot be studied thoroughly without referring to ideological and cultural transformations that accompany state-building.

Cultural, ethnic, and nationalist movements all constituted a major dynamic during Turkish transformation, and power groups with no clear class base appeared as the central actors. In this respect, analyzing informal opposition provided the grounds for looking at the movements of the broader society. Moreover, by focusing on movements of resistance, it became possible to analyze how national hegemony became established and how it has been challenged by alternative power groups.

Not all acts of resistance can be located in the domain of politics. Forms of resistance that bring transformation should be distinguished from other forms that only refiect different subject positions with no further political implications. For example, ethnicity is an ambivalent source in mobilizing local populations, and, in times of social disturbance, it is difficult to detect the forces that determine the direction of ethnic movements. Ethnic movements may or may not be transformed from movements of resistance to movements of opposition. In the Turkish case. local forms of resistance such as Muslim and nonMuslim ethnic resistance, constituted various axes of tension between the state-makers and the resisters which influenced the form and nature of the new Turkish state. Thus, 
although not all forms of resistance play a role in explaining history, most of the precapitalist forms of resistance analyzed in this study did have an impact on the development of a more developed Turkish state and a more detailed form of government.

The absence or the silence of resistance in the Turkish literature influenced the conceptualizations of state-formation. One of the weaknesses is to see the Turkish Revolution as imposed upon the masses, and to argue that there has been no serious opposition or resistance to the state-builders. Secondly, when the 'resistance' side of stateformation remains absent then the military class or the bureaucrats, the nature of state policies, and the reforms undertaken by the state appear as the focal points of analysis reflecting only the 'domination' side of state-formation. However, it is important to consider various movements of resistance in order to be able to analyze the nature of the exercise of state power. In this respect it is necessary to think in more local terms, and to consider different regions or provinces in a comparative framework. Such an approach is more revealing than taking Turkey as a unitary object.

In this study, I did not rely on formal class or occupational categories (such as bureaucrats) since these categories prevent one from seeing not only the transformations that took place inside a class, but also the historical and cultural realities of the everyday life of Turkish people. In this sense, military desertion, social banditry, and the revolts and disturbances discussed in this study reveal much about peasant life in Turkey since it fills the 'gap' between constitutional and legislative texts on the one hand, and the 'real world' on the other hand. 
In view of the point discussed above. the perspective that I have followed in this dissertation, which concentrates on the internal history of state making. contributed to developing a framework where state-building in the West can be compared to statebuilding in Turkey on firmer grounds. Earlier I have argued that the form of the new Turkish state was basically the West European one, but that the path of development was divergent and distinct from that of the West European states. Turkish state builders imitated the West European form of nation-state which they regarded as the only viable form of polity while attempting to create a common 'Turkish culture' as distinct from 'Western culture'. Their aim was to attain national cohesiveness and unity through creating a common culture of their 'own'. In order to homogenize the society, statebuilders tried to eliminate the deep rooted and widespread linguistic. cultural, and religious diversity in Anatolia by imposing upon the constituent populations of the new state their own cultural and political heritage which was heavily influenced by Western ideas.

At this point Elias' conceptualizing of state-building as a 'civilizing process' fits to the Turkish case. Turkish nationalists imposed upon the rest of the population (Western) 'civilized' patterns of conduct and this confrontation of the Western civilizing movement with the pre-existing forms of civilization in Anatolia created tensions between the two forms of civilization, which Elias sees as an integral part of the whole civilizing process. Thinking in Elias' terms, it can be inferred that the tensions and struggles between the two forms of civilization, fuelled by two different religions, are still existent in Turkey today. This constitutes one characteristic of nationalism beyond the West which causes changes 
in the structure of human relations different than the changes that took place in the West. The distinctive aspects of this change is reflected in the various forms of resistance discussed in this study. Besides this, it is in this context that one can bring together the contradicting elements of Turkish nationalism such as the adoption of Western hat or the introduction of ball rooms as symbolizing 'modernity', and the attempts to create myths of origin and myths of common destiny, language, and ethnicity. Each of these diverse attempts to create a sense of an imagined national community contributed to the creation of a common culture in their own ways. This points to the characteristic aspect of Turkish nationalism; while former religious loyalties were transformed through Western symbols as in the case of replacing the fez with modern hat, new loyalties were imposed through myths of common destiny, language, and ethnicity to hide the existence of different subject positions. One can conclude that the main reason why the Turkish Nationalists were not successful in transforming particular, local, and regional subject positions into a common culture was their making use of diverse elements in inventing a Turkish national culture.

The last thing to be emphasized is that although the Turkish state was based on the European form of nation-state, it was created after the consciousness of a 'Turkish nation" had been developed among the Turks. What this indicates is that the path of development of the Turkish state was distinct from that of West European states. Furthermore, the fact that the Turkish state was not created by the deliberate efforts of the bourgeoisie contributes to the argument that Turkey toilowed a divergent path of development in comparison to West European states. In vics respect the experiment of Turkish state- 
building, representing a recent form of nationalism. sheds light to understanding the state in Third World Countries when comparing divergent forms of nationalism such as classical and modern.

As the last point, this study lays the ground for analyzing the identity problem that has been a major issue in the recent political discourse of Turkey. The Kemalist Revolution has been under serious attack since the 1980s, and the building of the nation-state is being challenged particularly by the Islamists and the Kurds. The construction of competing Turkish identities appears as a major problem that cannot be understood without analyzing the historical transformations that took place since the Ottoman times, especially during the formation of the new Turkish state.

The importance of regional histories in the construction of political or territorial claims is also important in understanding the shifts in modern forms of nationalist movements such as the recent Kurdish movement. Moreover, it is essential to be able to trace the transformations in state practices or policies in relation to the changing conceptions of the state. Consequently, to be able to analyze how loyalties were defined in the past and how they have been transformed recently becomes a challenging question to investigate. The changing relationship between the definitions of nation and state, or between nationalism and state constitute the crucial points of transition in the process of forming new collective identities, and this appears to be the case in Turkey since 1980s. 


\section{BIBLIOGRAPHY}

Abadan. Yavuz (1972) Mustafa Kemal ve Cetecilik (Mustafa Kemal and the Guerilas). Varlik Pub.. Istanbul.

(Adivar) Halide Edip (1926) Memoirs of Halide Edib, The Century Co., New YorkLondon.

(Adivar) Halide Edip (1928) The Turkish Ordeal, The Century Co., New York.

(Adivar) Halide Edib (1929) "Dictatorship and Reforms in Turkey" Yale Review, vol. 19. no. 1, pp. 27-44.

(Adivar), Halide Edib (1930) Turkey Faces West: A Turkish View of Recent Changes and Their Origin. Yale University Press, New Haven.

Adivar. Halide Edib (19871928) Turkun Aresle Imtihani: Kurtujus Savasi Anilari (The Turkish Ordeal: Memoirs of the Liberation War). Atlas Pub., Istanbul.

Ahmad, Feroz (1969) The Young Turks: The Committee of Union and Prooress in Turtish Politics 1908-1914, Oxford University Press, Oxford.

Alavi, Hamza (1982) "State and Class Under Peripheral Capitalism" in Alavi, H. and Shanin, T. (eds.) Introduction to the Sociology of 'Developing Societies'. Monthly Review Press, New York. 
Amin. Samir (1980) Class and Nation: Historically and in the Current Crisis. Monthly Press. New York.

Anderson. Benedict (1983) Imagined Communities: Reflections on the Origin and Spreild of Nationalism. Verso. London.

Anderson. Perry (1974) Lineages of the Absolutist State. Verso. London.

Andrews, Peter Alford (ed.) (1989) Ethnic Groups in the Republic ofTurkey, Dr. Ludwig Reichert Verlag, Wiesbaden.

Anthias. Floya and Yuval-Davis, Nira (1989) "Introduction" to F. Anthias and N. YuvalDavis (eds.) Woman-Nation-State, Macmillan, London.

Arjomand. S. A. (1982) "Searching for the Collective Consciousness - Durkheim Ideological Impact in Turkey and Iran" in American Sociologist, vol. 17, no. 2, pp. 94 102.

Armstrong, Harold (1925) Turkey in Travail: The Birth of a New Nation, John Lane the Bodley Head Limited, London.

Ataturk, Mustafa Kemal (1927) Speech, Ministry of Education Printing Plant, Istanbul.

Ataturk, M. Kemal (1991) Ataturk'un Tamim. Telgraf ve Beyannameleri, cilt IV. (Ataturk's Circulars, Telegrams, and Manifestos, vol. IV) Ataturk Research Center, Turkish Historical Society Pub., Ankara. 
Atay, Falih Rifki (1958) Cankaya: Ataturk Devri Hatiralari, cilt. I. (Cankaya: Memoirs of the Ataturk Period, vol. I). Dunya Pub.

Avcioglu. Mogan (1986) Milli Kurtulus Tarihi (1838'den 1995'e), cilt III. [History of the National Liberation (From 1838 to 1995), vol. III], Tekin Pub., Istanbul.

Ayata, Sencer (1991) "Traditional Sufi Orders on the Periphery: Kadiri and Naksibendi Islam in Konya and Trabzon" in Richand Tapper (ed.) Islam in Modem Turkey: Religion. Politics and Literature in a Secular State. I.B. Tauris \& Co Ltd., London.

Aybars, Ergun (1988) Istiklal Mahkemeleri-1920-1927, cilt I-II (The Courts of Independence 1920-1927, vol. I-II), Dokuz Eylul University Pub.. Izmir.

Badie, Bertrand and Birnbaum. Pierre (1983) The Sociology of the State. The University of Chicago Press, Chicago.

Baykan, A: ergul (1990) "Women Between Fundamentalism and Modernity" in B. Turner (ed.) Theories of Modernity and Postmodernity. Sage. London.

Bayrak, Mehmet (1985) Eskivalik ve Eskiva Turtuleri (Banditry and Folk Songs on Banditry), Yorum Pub., Ankara.

Berkes, Niyazi (1957) "Historical Background of Turkish Secularism" in Frye, Richard N. (ed.) Islam and the West, Mouton and Co., The Hauge, The Netherlands.

Berkes, Niyazi (1964) The Development of Secularism in Turkey, McGill University Press, Montreal. 
Berkes. Niyazi (1978) Turkive'de Cagdaslasma (Secularism in Turkey). Dogu-Bati Pub.. Istanbul.

Bezucha. Robert (1976) 'The Moralization of Society: The Enemies of Popular Culture in the Nineteenth Century" in Beauroy. Jacques et al (eds.) Ropular Culture in France: The Wolf and the Lamb. Anmi Libri. Saratogoa, Ca.

Billingsley, Phil (1981) "Bandits, Bosses, and Bare Sticks: Beneath the Surface of Lucal Control in Early Republican China" Modem China, vol. 7. no. 3. pp. 235-288.

Birinci, Ihsan (1971) "Milli Mucadele Icin Kurulan Ceteler ve Cemiyetler" (Guerilla Bands and Societies Formed for National Liberation) Hayat Tarih Mecmuasi. vol. 2. no. 9. pp. 29-35; vol. 2, no. 10, pp. 55-61.

Blaut. James M. (1987) The National Ouestion: Decolonizine the Theory of Nationalism. Zed Books . London.

Bourdieu, Pierre (1977) Qutline of a Theory of Practice, Cambridge University Press. Cambridge.

Bozdemir, Mevlut (1982) Turk Ordusunun Tarihcel Kaynaklari (The Historical Roots of the Turkish Army), SBF Pub., Ankara.

Breuilly, John (1982) Nationalism and the State, St. Martin's Press, New York.

Callinicos, Alex (1987) "Ideology and Power" in Making History Polity Press, Cambridge. 
Canak. William L. (1984) "The Peripheral State Debate: State Capitalist and Bureaucratic-Authoritarian Regimes in Latin America" Latin American Research Review vol. 19, no. 1, pp. 3-36.

Carnoy, Martin (1984) The State and Political Theory Princeton University Press. Princeton.

Carr, Edward Hallett (1945) Nationalism and After. The Macmillan Company, New York.

Carr. Edward Hallett (1953) The Bolshevik Revolution 1917-1923, vol. III. The Macmillan Company, New York.

Cesur-Baykan. Aysegul (1988) The Transition From Otoman Empire To Turkish Republic: A Seanch for Social Identity Ph. D. Dissertation, Department of Sociology. University of Pittsburgh, Pittsburgh.

Cohn. N (19701957) Bursuit of the Milleneum. Temple Smith. London.

Connor Walker (1972) "Nation-Building or Nation-Destroying?" World Politics, vol. 24. no. 3. p. 319.

Corrigan. Philip (1980) "Towards a History of State Formation in Early Modern England" in Corrigan. Philip (ed.) Capitalism. State Formation and Marxist Theory, Quartet, London. 
Corrigan. Philip (1988) "The Politics of Feeling Good: Reflections onMarxism and Cultural Production" in Gruneau. Richard (ed.) Popular Culture and Political Priacices. Garamond, Toronto.

Corrigan. Philip: Ramsay. Harvie and Sayer. Derek (1980) "Tie State as a Relation of Production" in Corrigan. Philip (ed.) Capitalism. State Formation and Marxist Theors. Quartet. London.

Corrigan. Philip and Sayer,Derek (1985) The GreatArch: English State Formation ils Cultural Revolution. Basil Blackwell. Oxford.

Davison. Roderic H. (1981) "Peaceful Foreign Relations: An Achievement of Ataturk" in Review of the Faculty of Political Sciences, University of Ankara. vol. 36, no. 1-4. pp. 167-179.

Dearlove, John (1989) "Bringing the Constitution Back In: Political Science and the State" Political Sudies. vol. 37, no. 4. pp. 521-539.

Dunn, Robert (1958) World Alive, Robert Hale Limited, London.

Egilmez. Mumtaz Suknu (1981) Milli Mucadele'de Bursa (Bursa in the National Liberation War), Tercuman Tarih Pub., Istanbul.

Elias, Norbert (1982) The Civilizine Process: Vol II: State For ation and Civilization. Blackwell, Oxford. 
Ergil. Dogu (1974) "A Theoretical Note on the Causes of Revolutionary Peasant Movements" Milledlerarasi Munasebetler Turk Yilligi. vol. 14. pp. 69-91.

Eroglu. Hamza (1990) Turk Inkilap Tarihi (History of the Turkish Revolution). Savas Pub., Ankara.

Foucault, Michel (1979) "Governmentality" Ldeology and Consciousness. no. 6. pp. 5-21.

Foucault. Michel (1980A) Power and Knowledge: Selecited Interviews andOther Writings 1972-1977, edited by Colin Gordon, Pantheon Books, New York.

Foucault. Michel (1980B) History of Sexuality, vol. I. Vintage Books. New York.

Foucault. Mirhel (1981) "Omnes et Singulatim: Towards a Criticism of 'Political Reason' " in The Tanner Lectures on Human Values, vol. II. Lniversity University of Utah Press, Salt Lake City.

Foucault. Michel (1982) "The Subject and Power" in Dreyfus, H. and Rabinow, P. Michel Eoucault: Beyond Structuralism and Hermeneutics, University Chicago Press, Chicago.

Frazer, David (1910) Persia and Turkey in Revolt, William Blackwood and Sons, London.

Frey. Frederick W. (1965) The Turkish Political Elice, The M. I. T. Press, Cambridge.

Gates, Caleb F. (1940) Not 10 Me Only, Princeton University Press, Princeton.

Gellner, Emest (1983) Nations and Nationalism, Comell University Press, Ithaca. 
Gellner, Emest (1983A) 'The Tribal Society and its Enemies" in Tapper, Richard (ed.) The Conflict of Tribe and State in Iran and Afghanistan. Croom Helm. London.

Giddens. Anthony (1985) The Nation-State and Violence. Polity, Cambridge.

Goffman. Daniel (1994) "Ottoman Millets in the Early Seventeenth Century" New Perspectives on Turkey, Fall 1994, no. 11. pp. 135-158.

Gologlu, Mahmut (1968) Erzunum Kongresi (Erzurum Congress), Nuve Matbaasi. Ankara.

Gologlu, Mahmut (1972) Devrimler ve Tepkileri (1924-1930) [Reforms and Resistance (1924-1930)]. Basnur Matbaasi, Ankara.

Gole, Nilufer (1991) Modem Mahrem: Medenivet ve Ortunme (Modern Privacy: Civilization and Veiling), Metis Pub., Istanbul.

Gramsci, Antonio (1973) Selections From the Prison Notebooks. Hoare. Quintin and Smith, G. N. (eds.), Lawrence and Wishart, London.

Gulalp, Haldun (1994) "Capitalism and the Modern Nation-State: Rethinking the Creation of the Turkish Republic" Joumal of Historical Sociology, vol. 7. no. 2, pp. 155-176.

Gunes-Ayata, Ayse (1990) "Class and Clientelism in the Republican People's Pany" in Finkel, Andrew and Sirman, Nukhet (eds.) Turkish State. Turkish Society, Routledge. London. 
Gurun, Ka Iuran (1988) Ermeni Dosyasi (The Armenian File), Bilgi Pub., Ankara.

Haddad, W. William (1977) "Nationalism in the Ottoman Empire" in W. W. Haddad and W. Ochsenwald (eds.) Nationalism in a Non-National State: The Dissolution of the Qttoman Empire, Ohio University Press, Columbus.

Hall, Stuart (1984A) 'The Rise of the Representative/Interventionist State" in McLennan. G., Held, D. and Hall, S. (eds.) State and Society in Contemporary Britain. Polity, Cambridge.

Hall. Stuart (1984B) "The State in Question" in McLennan, G., Held, D., and Hall, S. (eds.) The Idea of the Modem State, Open University Press, Milton Keynes.

Harris, George S. (1967) The Origins of Communisn in Turkey Hoover Inst., Stanford.

Herbert. Aubrey (1924) Ben Kendim: A Record of Eastem Travel, Hutchinson and Co., London.

Hiziroglu-Tokluoglu. Ceylan (1985) The Durkheimian Influence on Gokalo's Sociology and Nationalism, MSc Thesis, Department of Sociology, Middle East Technical University, Ankara.

Hicyilmaz, Ergun (1993) Basverenler Baskaldiranlar (Martyrs and Rebels), Altin Kitaplar Pub.. Istanbul.

Hicyilmaz. Ergun (1993A) Gizli Belaelerle Cerkes Ethem (Secret Documents on Circassian Ethem), Varlik Pub., Istanbul. 
Hobsbawm. Eric (1959) Primitive Rebels: Studies in Archaic Forms of Social Movement in the Nineteenth and Twentieth Centuries, Frederick A. Praeger, New York.

Hobsbawm, Eric (1969) Bandits, Delacorte Press, New York.

Hobsbawm, Eric (1983) "Introduction: Inventing Traditions" in Hobsbawm, Eric and Ranger. Terence (eds.) The Invention of Tradition, Cambridge University Press. Cambridge.

Hobsbawm, Eric (1990) Nations and Nationalism Since 1780: Proqramme, Myth. Reality, Cambridge University Press, Cambridge.

Igdemir, Ulug (1973) Bipa Avaklanmasi ve Anzayur Olaylari (Gunluk Anilar) (Biga Revolt and the Incident of Anzavur (Memoirs)], Turkish Historical Society Pub. Ankara.

Inalcik, Halil (1964) "The Nature of Traditional Society: Turkey" in R. E. Ward and D. A. Rustow (eds.) Political Modernization in Japan and Turkey Princeton University Press, Princeton.

Inalcik, Halil (1969) "Capital Formation in the Ottoman Empire" The Joumal of Economic History vol. XXIX, no. 1, p. 97-140.

Inonu, Ismet (1992) Hatiralar cilt I (Memoirs, vol. I), Bilgi Pub., Ankara. Jessop, Bob (1982) The Capitalist State: Marxist Theories and Methods, Martin Robertson, Oxford. 
Jessop, Bob (1989) "Capitalism, Nation-states and Surveillance" in Held. David and Thompson, John B. (eds.) Social Theory of Modem Societies: Anthony Giddens and his Critics. Cambridge University Press. Cambridge.

Kabacali, Alpay (1991) Tarihimizde Kurtler ve Ayaklanmalari (The Kurds and Their Revolts in Turkish History), Cem Pub., Istanbul.

Kabasakal, Mehmet (1991) Turkive'de Sivasal Parti Orgutlenmesi 1908-1960(The Organization of Political Parties in Turkey 1908-1960), Tekin Pub., Istanbul.

Karal. Enver Ziya (1971) Turkive Cumhuriveti Tarihi (1918-1965) [The History of Turkish Republic (1918-1965)], Milli Egitim Pub., Istanbul.

Karpat, Kemal (1973) An Inquiry Into the Social Foundations of Nationalism in the Qtoman State, Princeton University Center for International Studies, Research Monograph. No. 39.

Karpat. Kemal (1975) "The Memoirs of N. Batzaria: The Young Turks and Nationalism" Intemational Joumal of Middle East Studies, vol. 6, p. 276.

Kandiyoti, Deniz (1989) "Women and the Turkish State: Political Actors or Symbolic Pawns?" in N. Yuval-Davis and F. Anthias (eds.) Woman-Nation-State, McMilland. London. 
Keyder. Caglar (1988) "Class and State in the Transformation of ModernTurkey" in Halliday. F. and Alavi. H. (eds.) State and Ideology in the Middle East and Pakistian. Monthly Review Press. New York.

Keyder. Caglar (1993) "The Dilemma of Cultural Identity on the Margin of Europe" Beview, vol. XVI, no. 1, pp. 19-33.

Kili, Suna (1983) Ataturk Devrimi: Bir Cagdaslasma Modeli (Ataturk's Revolution: A Model for Modernization), Turkiye Is Bankasi Kultur Pub.. Ankara.

Kinross, Lord (1965) Ataturk: The Rebirth of a Nation. Weidenfels and Nicolson. London.

Kohn, Hans (1958) The Ider of Nationalism: A Study in Its Origins and Backeround. The Macmillan Company, New York.

Kohn, Hans (1965) Nationalism: Its Meaning and History, D. Van Nostrand Company. New York.

Kurat, Yulug Tekin (1967) "How Turkey Drifted into World War I" in K. Bourne and D. C. Watt (eds.) Intemational Studies, Longmans, London.

Kurat, Yulug Tekin (1991) "Cumhuriyet'in Mesrutiyet ile Mucadelesi" (Struggle of Turkish Republican Ideology Against the Traditional Constitutional Monarchy). International Symposium Commemorating the 50th Anniversary of Ataturk. November 1988, Middle East Tech. University Publication, pp. 85-96. 
Lewis, Bernard (1968 1961) The Emergence of Modem Turkey, Oxford University Press. Oxford.

Lowy, Michael (1976) "Marxists and the National Question" New Left Review, vol. 96. p. 81.

Mann. Michael (1986) The Source of Social Power, Cambridge University Press, Cambridge.

Mardin, Serif (1965) "Opposition and Control in Turkey" Government and Opposition. vol. I. pp. 375-387.

Mardin, Serif (1969) "Power, Civil Society and Culture in the Ottoman Empire" Comparative Studies in Society and History, vol. II, pp. 258-281.

Mardin. Serif (1971) "Ideology and Religion in the Turkish Revolution" International Joumal of Middle East Studies, vol. 2, no. 3, pp. 197-211.

Mardin, Serif (1973) "Center-Periphery Relations: A Key to Turkish Politics?" Daedalus, vol. 102, p. $169-190$.

Mardin. Serif (1977) "Religion in Modern Turkey" International Social Science Joumal, vol. 29. no. 2. pp. 279-297.

Mardin. Serif (1981) "Religion and Secularism in Turkey" in Kazancigil, Ali and Ozbudun. Ergun (eds.) Ataturk: Eounder of a Modem State, Archon Books, Hamden, Connecticut. 
Mardin, Serif (1983 1964) lon Turklerin Sivasi Fikirleri 1895-1908 (The Political Thoughts of the Young Turks 1895-1908). Iletisim Pub.. Istanbul.

Mardin. Serif (1989) Religion and Social Change in Modem Turkey: The Case of Bediuzzaman Said Nursi. State University of New York Press. New York.

Mardin, Serif (1991) "The Naksibendi Order in Turkish History" in Richard Tapper (ed.) Islam in Modem Turkey: Religion. Politics and Literature in a Secular State. I.B. Tauris \& Co Ltd., London.

Mazici, Nursen (1984) Beleclerle Ataturk Doneminde Muhalefet 1919-1926(Documents on Opposition During the Ataturk Revolution 1919-1926), Dilmen Pub.. Istanbul.

McCarthy, Justin (1983) "Foundations of the Turkish Republic: Social and Economic Change" in Middle Eastem Studies, vol. 19, no 2. pp. 139-151).

McCarthy, Justin \& McCarthy, Carolyn (1989) Turks and Armenians: A Manual on the Armenian Question, Assembly of Turkish American Associations, Washington, D.C.

Mehmet Arif Bey (1987) Anadolu Inkilabi: Milli Mucadele Anilari(1919-1923) [Anatolian Revolution: Memoirs of the Struggle for Independence (1919-1923)], Arba Pub., Istanbul.

Mert, Ozcan (1992) "Anzavur'un Ilk Ayaklanmasina Ait Belgeler" (Documents on Anzavur's First Revolt) Belleten, vol. LVI, no. 217, pp. 847-961. 
Moore, Barrington (1974 1966) Social Origins of Dictatorship and Democracy: Lord and Peasant in the Making of the Modem World, Penguin University Books. Great Britain.

Moore. B (1978) Iniustice: The Social Bases of Obedience and Revolt. M. E. Sharpe. New York.

Morgenthau, Hary (1918) Ambassador Morgenthau's Story Doubleday, Page and Company, New York.

Morgenthat, Hary (1922) All in a Life-Time, Doubleday, Page and Company, New York.

Mullett. M. (1987) Bopular Culture and Popular Protest in Late Medieval and Early Modern Europe, Croom Helm, London.

Mumcu, Ugur (1991) Kurt-Islam Avaklanmasi 1919-1925 (The Kurdish-IslamicRebellion 1919-1925), Tekin Pub.. Istanbul.

Muderrisoglu, Alptekin (1974) Kurtulus Savasinin Mali Kaynaklari (The Financial Sources of the Liberation War), Maliye Bakanligi Pub., Ankara.

Nairn. Tom (1977) The Break-up of Britain: Crisis and Neo-Nationalism, NLB, London.

Nimni, Ephraim (1989) "Marx. Engels and the National Question" Science and Society. vol. 53, no. 3, p. 297.

Noyan. Bedri (1982) "Folklorda ve Yasamda Aydin Efesi" (The Efe of Aydin in Folklore and in Life) Turk Folklon, vol. 3, no. 35, pp. 8-12) 
Olson. Rober (1989) The Emergence of Kurdish Nationalism and the Sheikh Said Rebellion. 1880-1925. University of Texas Press. Austin.

Oran, Baskin (1990) Atarurk Millixetciligi: Resmi ldeoloji Disi Bir Inceleme (Ataturk's Nationalism: An Analysis Beyond the Official Ideology). Bilgi Pub., Ankara.

Ozbudun, Ergun (1970) "Established Revolution Versus Unfinished Revolution: Contrasting Patterns of Democratization in Mexico and Turkey" in Huntington. Samuel P. and Moore, Clement H. (eds.) Authoritarian Politics in Modem Society: The Dynamics of Established One-Party Systems, Basic Books. New York.

Ozturk, Mustafa (1990) "XVIII. Yuzyilda Antakya ve Cevresinde Eskiyalik Olaylari" (The Incidents of Brigandage in and around Antakya in the Eighteenth Century) Belleten, vol. 54. pp. 963-993.

Ozturkmen, Arzu (1994) "The Role of People's Houses in the Making of National Culture in Turkey" New Perspectives on Turkey, no. 11, pp. 159-181.

Poulantzas, Nicos (1976) The Crisis on the Dictatorships: Portugal, Greece, Spain, New Left Books, London.

Powell, Alexander E. (1923/1976) The Struggle For Power in Muslim Asia. Progressive Books, New York.

Price, Claire (1923) The Rebirth of Turkey, Thomas Seltzer, New York. 
Ramsaur. Emest E. (1970 1957) The Young Turks: Prelude to the Revolution of 1908. Russell \& Russell. New York.

Rawlinson, A. (1923) Adventures in the Near East: 1918-1922. Andrew Melrose. London.

Reed. Howard A. (1957) "The Religious Life of Modem Turkish Muslims" in Frye. Richard N. (ed.) Islam and the West, Mouton and Co.. The Hague. The Netherlands.

Scott. James C. (1985) Weapons of the Weak: Everyday Forms of Peasant Resistance. Yale University Press, New Haven.

Selek, Sabahattin (1963) Milli Mucadele: Anadolu Thtilali cilt I (National Struggle: Anatolian Revolution, vol. I), Gunes Pub., Istanbul.

Selek. Sabahattin (1965) Milli Mucadele: Anadolu Thtilali, Yeni Turk Devletinin Kurulusu, cilt II. (National Struggle: Anatolian Revolution. The Formation of the new Turkish State), vol. II, Istanbul.

Shanin, Teodor (1986) "Soviet Theories of Ethnicity: The Case of a Missing Term" New Left Review no. 158. p. 113.

Shaw, Martin (1989) "War and the Nation-state in Social Theory" in Held, David and Thompson. John B. (eds.) Social Theory of Modem Societies: Anthony Giddens and his Critics. Cambridge University Press, Cambridge.

Simon. Roger (1982) Grameci's Political Thought: An Introduction, Lawrence and Wishar, London. 
Smith. Anthony D. (1981) The Ethnic Revival in the Modem World. Cambridge University Press. Cambridge.

Smith. Anthony D. (1983) Theories of Nationalism. Duckworth, London.

Smith. Anthony D. (1984) "National Identity and Myths of Ethnic Descent" Bescarch in. Social Movements, Conflict and Change, vol. 7. pp. 95- 130.

Smith, Elaine Diana (1959) Turkey: Origins of the Kemalist Movement and the Government of the Grant National Assembly (1919-1923). The American University. Washington. D. C., Ph. D. Dissertation.

Skocpol, Theda (1978) States and Social Revolutions: AComparative Analysis of France. Bussia and China, Cambridge University Press, Cambridge.

Skocpol. Theda (1985) "Bringing the State Back In: Strategies of Analysis in Current Research" in Evans, P. R., Rueschemeyer, D., and Skocpol. T. (eds.) Bringine the State Back In. Cambridge University Press. Cambridge.

Sonyel, Salahi R. (1988) The Turco-Armenian 'Adana Incidents' in the Light of Secret British Documents (Julv. 1908-December. 1909], Turkish Historical Society Pub.. Ankara.

Steinhaus, Kurt (1974) Atapurk Devrimi Sosyolojisi (The Sociology of Ataturk's Revolution), Sander Pub., Istanbul. 
Stojanovic. Miodrag (1984) Haiduks and Klephts in Folk Poetry, Serbian Academy of Sciences and Arts-Institute for Balkan Studies. no. 18, Belgrade.

Sugar, Peter (1964) "Economic and Political Modernization: Turkey" in R. E. Ward and D. A. Rustow (eds.) Political Modemization in Japan and Turkey, Princeton University Press, Princeton.

Sunar. Ilkay (1974) State and Society in the Politics of Turkey's Development. Ankara University Faculty of Political Science Publication, no. 377. Ankara.

Sener. Cemal (1986) Cerkes Ethem Olayi (The Case of Circassian Ethem), Ant Pub.. Istaniul.

Serisr, Cemal (1992) Topal Osman Olayi (The Case of Topal Osman), Ant Pub.. Istanbul.

Simsir, Bilal (1975) British Documents on Atatudk (1919-1938), vol. II April-December 1920. Turkish Historical Society Pub., Ankara.

Simsir, Bilal (1992) British Documents on Atanurk (1919-1938), vol. I April 1919- March 1920. Turkish Historical Society Pub., Ankara.

Tachau, Frank (1984) "The Political Culture of Kemalist Turkey". in J. M. Landau (ed.) Alaturk and the Modernization of Turkey, Westview Press, Colorado.

Tanor. Bulent (1990) "The Place of Parliament in Turkey" in Finkel. Andrew and Sirman. Nukhet (eds.) Turkish State. Turkish Society Routledge. London. 
Tapper. Richard (ed.) (1983) "Introduction" to The Conflict of Tribe and State in Iran and Afghanistan. Croom Helm. London.

Thompson. E. P. (1991) Customs in Common. The New Press. New York.

Tilly. Charles (1975) The Formation of National States in Westem Europe. Princeton University Press. Princeton.

Tilly. Charles (1978) Erom Mobilization to Revolution, Reading. Mass.:Addison-Wesley.

Tilly. Charles (1981) As Sociology Meets History Academic Press, New York.

Timur. Taner (1993\1971) Turk Devrimi ve Sonras: (The Turkish Revolution and its Aftermath). Imge Pub.. Ankara.

Toker, Metin (19941968) Seyh Sait ve Isvani (Sheikh Sait and his Revolt), Bilgi Pub.. Ankara.

Toynbee, Amold J. (1923) The Westem Question in Greece and Turkey, Constable and Company Lid., London.

Traverso. Enzo and Lowy. Michael (1990) "The Marxist Appioach to the National Question: A Critique of Nimni's Interpretation" Science and Society, vol. 54, no. 2. p. 132.

Trimberger. Ellen K. (1978) Revolution From Above: Military Bureaucrats and Development in Japan. Turkey. Egyph and Pen. Transaction Books, New Brunswick. 
Tunaya. Tarik Zafer (1984) Turkive'de Sivasal Partiler: Ikinci.Mesrutiyet Donemi (19081918]. cilt I. [Political Parties in Turkey: The Second Constitutional Monarchy (19081918). vol.1]. Hurriyet Vakfi Pub., Istanbul.

Tunaya, Tarık Zafer (1989) Turkıve'de Sivasal Paniler: Ittihat ve Terakki. cilt. III [Political Parties in Turkey: The L'nion and Progress, vol. III], Hurriyet Vakfi Pub.. Istanioul.

Tuncay. Mete (1991) Turkjye'de Sol Akimlar (1908-1925), cilt I (Leftish Movements in Turkey, vol. I), BDS Pub.. Istanbul.

Tuncay, Mete (1992 1981) Turkiye Cumhuriyeti'nde Tek Parti Yonetiminin Kunulmasi 1923-1931) [The Establishment of the Single Panty Rule inthe Turkish Republic (1923-1931)]. Cem Pub., Istanbul.

Ucok, Bahriye (1979) "Yazi Devrimi - Kur'an Harfleri ve Ataturk Devrimlerine Karsi Cikislar" (The Alphabet Reform - The Koranic Script and Opposition to Ataturk's Reforms) Belleten, vol. 43, no. 172, pp. 823-836.

Clucay, M. Cagatay (1944) XVII. Asirda Saruhan'da Eskivalik ve Halk Hareketleri (Brigandage and Popular Movements in Saruhan in the Seventeenth Century), Resimli Ay Matbaasi, Istanbul.

Urry. John (1981) The Anatomy of Capitalist Societies: The Economy, Civil Society and the State, Macmillan, London. 
Van Bruinessen. Martin (1983) "Kurdish Tribes and the State of Iran: The Case of Simko's Revolt" in Tapper. Richard (ed.) The Conflict of Tribe and State in Iran and Afghanistan. Croom Helm. London.

Van Bruinessen. Martin (1989) "The Ethnic Identity of the Kurds" in Peter Alford Andrews (ed.) Ethnic Groups in the Republic of Turkey, Dr. Ludwig Reichen Verlag. Wiesbaden.

Van Bruinessen. Martin (1992/1978) Agha. Shaikh and State: The Social and Political Structures of Kurdistan. Zed Books Ltd., London.

Wallerstein, Immanuel '1974) The Modem World System, vol. I, Academic Press, New York.

Wolf. E. (1969) Peasant Wars of the Twentieth Century Harper. New York.

Wolin. Sheldon (1989) The Presence of the Past: Essays on the State and the Constitution. The Johns Hopkins University Press, Baltimore.

Yalcin-Heckmann, Lale (199i) Tribe and Kinship Amon; the Kurds, Peterlang. Frankfurt am Main.

Yalcin-Heckmann, Lale (1991A) "Ethnic Islam and Nationalism Among theKurds in Turkey" in Richard Tapper (ed.) Islam in Modem Turkey: Religion. Politics and Literature in a Secular State, I.B. Tauris \& Co Ltd., London. 
360

(Yalman) Ahmed Amin (1930) Turkey in the World War, Yale University Press. New Haven.

Yalman, Ahmet Amin (1956 1930) Turkey in My Time. University of Oklahoma Press.

Norman.

Zolberg, A. R. (1987) "Beyond the Nation-State: Comparative Politics in Global Perspective" in Bering, J. and Blockmans, W. (eds.) Beyond Progress and Development: Macro-Political and Macro-Societal Change, Avebury. Aldershot. 


\section{GLOSSARY OF TURKISH TERMS}

Aga: A title of respect. and the owner of the biggest piece of land in a village Anadolu: Anatolia. Asia Minor

Bay: Mister (before name) modern usage

Bey: Mister, title (following name) older usage

Cerkes: Circassian

Dervis: dervish, a member of any of various Moslem fratemities or orders taking vow's of poverty and austerity

Efendi: a title following name, gentlemen

Fetva: Muslim jurid: $\cdot$ al decision or ruling

Firka: Political party, aimy brigade

Ferman: Royal decree

Gazi: Ghazi, victor, conqueror

Gerilla: Guerilla

Grand Vizier (Vezir): Prime Minister

Haci: Hadji, pilgrim, one who had been to Mecca

Hakim: Judge

Halk: People, folk

Halkcilik: Populism, 'Democratic' spirit

Hanim: Mrs., Miss (old usage). New usage, bayan before name

Harp: War

Heyet: commission, body

Hilafet: Caliphate

Hoca: Hodja, mosque school teacher, religious functionary

Hukuk: Law, jurisprudence

Hurriyet: Liberty, freedom

Imam: Muslim preacher, leader of public worship in mosque

Kadi: cadi, Muslim Judge

Kanun: Law

Kanunu Esasi: Fundamental law, constitution

Kuran: Koran, Quran

Kuvay-i Inzibatiye: disciplinary forces, Army of the Caliphate

Kuvay-i Milliye: Nationalist Forces, irregular Kemalist forces

Kuvay-i Nizamiye: regular army

Liva: administrative subdivision of Ottoman province

Mebus: deputy

Mecelle: Muslim civil code

Meclis: parliament, council

Meclis-i Mebusan: parliament, chamber of deputies

Medrese: Muslim school attached to mosque

Memur: official, functionary

Mesrutiyet: constitutional government

Milli Misak: National Pact 
Milli Misak: National Pact

Millet System: Ottoman administration of non-Muslim subjects

Molla: Muslim municipal judge, leamed man. doctor of theology

Mutasarrif: govemor of a 'liva' or 'sancak' which was an administrative district smaller than a province

Mufti: Doctor of Islamic Law. rank of Mufti

Nutuk: speech

Osmanli: Ottoman

Padisah: Snvereign. Sultan, King

Pasa: Pasha. a General, also a title placed after a name given to officers of high rank. and a civilıan title

Reddi Ilhak: rejection of annexation or occupation

Rum: Greek minority in Ottoman Empire

Rumeli: Rumelia

Sadrazam: Prime Minister, Minister

Sancak: administrative provincial subdivision of the Ottoman Empire

Seyyar Kuvvetler. mobile forces, irregular forces

Sunni: Sunni. Sunnite sect of Islam

Seriyet: Sheriat. Shari'a, Muslim divine law, sacred law

Seyh: sheikh, Chief, preacher, the head of an Arab family, or of a clan, tribe, or village

Seyhulislam: Sheikh-ul-Islam, head of Muslim hierarchy, highest religious authority

Sii: Shi'a. Shiite, Shiite sect of Islam

Tanzimat: Reformation of 1839

Turan: legenuary homeland of the Turks in Turkestan

Turanci: Turanist, Pan-Turanist

Turkculuk: Turkism

Turk Ocagi: Turkısh Heart. a cultural society

Turk Yurdu: Turkish Homeland, a cultural society and joumal

Uicma: ihe clergy, savants, learned men of Islan, inter preters of the Quran

Vali: governor of a nrovince

Vilayet: Province

Vezir: vezier. minister

Yeniceri: Janissaries, 'new soldiers' 
CHART: MAJOR SOCIAL AND POLITICAL EVENTS IN TURKISH HISTORY

\begin{tabular}{|c|c|c|c|c|}
\hline & $\begin{array}{c}\text { International } \\
\text { Events }\end{array}$ & $\begin{array}{l}\text { Ottoman and } \\
\text { Turkish State }\end{array}$ & $\begin{array}{c}\text { Political Parties } \\
\text { and } \\
\text { Organizations }\end{array}$ & $\begin{array}{l}\text { Etnic and } \\
\text { Minority } \\
\text { Resistance }\end{array}$ \\
\hline 1867 & & & $\begin{array}{l}\text { Establishment of } \\
\text { the 'Young Turk } \\
\text { Party' in Paris. }\end{array}$ & \\
\hline 1876 & & $\begin{array}{l}\text { Establishment of } \\
\text { the First Constitu- } \\
\text { tional Monarchy } \\
\text { by the Young Otto- } \\
\text { mans. }\end{array}$ & & \\
\hline 1878 & $\begin{array}{l}\text { Beginning of the } \\
\text { Ottoman-Russian } \\
\text { War. }\end{array}$ & $\begin{array}{l}\text { Abolishment of } \\
\text { the First Constitu- } \\
\text { tional Monarchy. }\end{array}$ & & \\
\hline 1889 & & . & $\begin{array}{l}\text { Formation of the } \\
\text { 'Committee of } \\
\text { Union and } \\
\text { Progress" (CUP) } \\
\text { (Young Turk } \\
\text { Movement). }\end{array}$ & \\
\hline 1908 & & $\begin{array}{l}\text { Establishment of } \\
\text { the Second Consti- } \\
\text { tutional Monarchy } \\
\text { (The Young Turk } \\
\text { Revolution). }\end{array}$ & & \\
\hline 1911 & & & $\begin{array}{l}\text { Formation of the } \\
\text { 'Party of Liberty } \\
\text { and Conciliation' } \\
\text { (opponents of the } \\
\text { Unionists). }\end{array}$ & \\
\hline 1912 & Balkan Wars. & & $\begin{array}{l}\text { Foundation of } \\
\text { 'Turkish Heart' } \\
\text { organization to } \\
\text { spread Turkish } \\
\text { nationalism by the } \\
\text { Young Turks. }\end{array}$ & \\
\hline
\end{tabular}




\begin{tabular}{|c|c|c|c|c|}
\hline & $\begin{array}{l}\text { International } \\
\text { Events }\end{array}$ & $\begin{array}{l}\text { Ottoman and } \\
\text { Turkish State }\end{array}$ & $\begin{array}{l}\text { Political Parties } \\
\text { and } \\
\text { Organizations }\end{array}$ & $\begin{array}{l}\text { Etnic and } \\
\text { Minority } \\
\text { Resistance }\end{array}$ \\
\hline 1913 & & & $\begin{array}{l}\text { 'Committee of } \\
\text { Union and } \\
\text { Progress' became } \\
\text { a political party. }\end{array}$ & \\
\hline 1914 & $\begin{array}{l}\text { Beginning of } \\
\text { World War I. }\end{array}$ & & & \\
\hline 1915 & & $\begin{array}{l}\text { Deportation of } \\
\text { Armenians from } \\
\text { Anatolia. }\end{array}$ & & \\
\hline 1918 & $\begin{array}{l}\text { End of World War } \\
\text { I. }\end{array}$ & & & \\
\hline 1919 & & $\begin{array}{l}\text { Erzurum and } \\
\text { Sivas Congresses. }\end{array}$ & $\begin{array}{l}\text { 'Party of Union } \\
\text { and Progress' dis- } \\
\text { banded itself. } \\
\text { 'Party of Liberty } \\
\text { and Conciliation' } \\
\text { reestablished. } \\
\\
\text { Formation of the } \\
\text { 'Societies For the } \\
\text { Defence of } \\
\text { National Rights'. }\end{array}$ & $\begin{array}{l}\text { Ali Bati } \\
\text { Revolt } \\
\text { (Kurdish); } \\
\text { Sheikh } \\
\text { Esref and } \\
\text { Bozkir } \\
\text { revolts: } \\
\text { Anzavur } \\
\text { Revolt } \\
\text { (Circas- } \\
\text { sian). }\end{array}$ \\
\hline
\end{tabular}




\begin{tabular}{|c|c|c|c|c|}
\hline & $\begin{array}{l}\text { International } \\
\text { Events }\end{array}$ & $\begin{array}{l}\text { Ottoman and } \\
\text { Turkish State }\end{array}$ & $\begin{array}{l}\text { Political Parties } \\
\text { and } \\
\text { Organizations }\end{array}$ & $\begin{array}{l}\text { Etnic and } \\
\text { Minority } \\
\text { Resistance }\end{array}$ \\
\hline 1920 & $\begin{array}{l}\text { Istanbul occupied } \\
\text { by the British. } \\
\text { Treaty of Sevres } \\
\text { signed between the } \\
\text { Ottoman govern- } \\
\text { ment and the } \\
\text { Allied Powers. } \\
\text { A treaty signed } \\
\text { between the Arme- } \\
\text { nians and the } \\
\text { Turks in Gumru } \\
\text { (Alexandropol). }\end{array}$ & $\begin{array}{l}\text { Passing of the } \\
\text { 'Law Against } \\
\text { Treason'. } \\
\text { Establishment of } \\
\text { the Courts of Inde- } \\
\text { pendence. } \\
\text { Declaration of the } \\
\text { National Pact (the } \\
\text { Program for Inde- } \\
\text { pendence). } \\
\text { Ottoman govern- } \\
\text { ment prorogued } \\
\text { itself and was dis- } \\
\text { solved by the Sul- } \\
\text { tan. } \\
\text { Openning of the } \\
\text { Grand National } \\
\text { Assembly. }\end{array}$ & $\begin{array}{l}\text { Establishment of } \\
\text { the Green Army. } \\
\text { Establishment of } \\
\text { the official 'Turk- } \\
\text { ish Communist } \\
\text { Party'. } \\
\text { Formation of the } \\
\text { 'People's Partici- } \\
\text { pation Party in } \\
\text { Turkey'. } \\
\text { Establishment of } \\
\text { 'Anatolian News } \\
\text { Agency'. }\end{array}$ & $\begin{array}{l}\text { Second } \\
\text { and Third } \\
\text { Anzadvur } \\
\text { revolts } \\
\text { (Circas- } \\
\text { sian); } \\
\text { Bolu. } \\
\text { Duzce. } \\
\text { Yozgal. } \\
\text { Zile, and } \\
\text { Konya } \\
\text { revolts; } \\
\text { Milli } \\
\text { Revolt } \\
\text { (Kurdish). }\end{array}$ \\
\hline
\end{tabular}




\begin{tabular}{|c|c|c|c|c|}
\hline & $\begin{array}{l}\text { International } \\
\text { Events }\end{array}$ & $\begin{array}{l}\text { Ottoman and } \\
\text { Turkish State }\end{array}$ & $\begin{array}{c}\text { Political Parties } \\
\text { and } \\
\text { Organizations }\end{array}$ & $\begin{array}{l}\text { Etnic and } \\
\text { Minority } \\
\text { Resistance }\end{array}$ \\
\hline 1921 & $\begin{array}{l}\text { First and Second } \\
\text { Battles of Inonu } \\
\text { and the Sakarya } \\
\text { Battle between the } \\
\text { Turks and Greeks. } \\
\text { Moscow Treaty } \\
\text { signed between } \\
\text { Ankara govern- } \\
\text { ment and Soviet } \\
\text { Russians. } \\
\text { A treaty signed } \\
\text { between Ankara } \\
\text { government and } \\
\text { the Soviets in } \\
\text { Kars. } \\
\text { Ankara Treaty } \\
\text { signed between } \\
\text { Ankara govern- } \\
\text { ment and the } \\
\text { French. }\end{array}$ & $\begin{array}{l}\text { Adoption of the } \\
\text { new constitution } \\
\text { (The Law of Fun- } \\
\text { damental Organi- } \\
\text { zation). } \\
\text { Formation of the } \\
\text { 'First Group' in } \\
\text { the Assembly by } \\
\text { Mustafa Kemal. }\end{array}$ & $\begin{array}{l}\text { Green Army, offi- } \\
\text { cial 'Turkish Com- } \\
\text { munist Party', and } \\
\text { 'People's Partici- } \\
\text { pation Party in } \\
\text { Turkey' eliminated } \\
\text { by the Courts of } \\
\text { Independence. }\end{array}$ & $\begin{array}{l}\text { Kocgiri } \\
\text { Revolt } \\
\text { (Kurdish): } \\
\text { Cerkes } \\
\text { Ethem's } \\
\text { forces } \\
\text { destroyed } \\
\text { by the regu- } \\
\text { lar army. }\end{array}$ \\
\hline 1922 & $\begin{array}{l}\text { End of the war } \\
\text { between Turks } \\
\text { and Greeks. } \\
\text { End of Turkish } \\
\text { War of Indepen- } \\
\text { dence. }\end{array}$ & $\begin{array}{l}\text { Abolition of the } \\
\text { Sultanate. }\end{array}$ & & \\
\hline 1923 & $\begin{array}{l}\text { Treaty of Lau- } \\
\text { sanne signed } \\
\text { between the } \\
\text { Ankara govern- } \\
\text { ment and the } \\
\text { Allied Powers. }\end{array}$ & $\begin{array}{l}\text { Republic pro- } \\
\text { claimed. } \\
\text { Law regarding the } \\
\text { elimination of } \\
\text { brigandage passed } \\
\text { the Assembly. }\end{array}$ & $\begin{array}{l}\text { Formation of the } \\
\text { Republican Party. }\end{array}$ & \\
\hline
\end{tabular}




\begin{tabular}{|c|c|c|c|c|}
\hline & $\begin{array}{c}\text { International } \\
\text { Events }\end{array}$ & $\begin{array}{l}\text { Ottoman and } \\
\text { Turkish State }\end{array}$ & $\begin{array}{c}\text { Political Parties } \\
\text { and } \\
\text { Organizations }\end{array}$ & $\begin{array}{l}\text { Etnic and } \\
\text { Minority } \\
\text { Resistance }\end{array}$ \\
\hline 1924 & & $\begin{array}{l}\text { The Law of 'Unifi- } \\
\text { cation of Educa- } \\
\text { tion' passed the } \\
\text { Assembly. } \\
\text { Caliphate abol- } \\
\text { ished. }\end{array}$ & $\begin{array}{l}\text { Formation of the } \\
\text { 'Progressive } \\
\text { Republican Party'. } \\
\text { Reestablishment } \\
\text { of 'Turkish } \\
\text { Hearts'. }\end{array}$ & $\begin{array}{l}\text { Nasturi } \\
\text { Revolt } \\
\text { (Kurdish). }\end{array}$ \\
\hline 1925 & & $\begin{array}{l}\text { The 'Law for the } \\
\text { Maintenance of } \\
\text { Public Order' } \\
\text { passed the Assem- } \\
\text { bly. } \\
\text { Courts of Indepen- } \\
\text { dence reestab- } \\
\text { lished. } \\
\text { 'Hat Law' prohib- } \\
\text { iting the wearing } \\
\text { of the 'fez' passed } \\
\text { the Assembly. }\end{array}$ & $\begin{array}{l}\text {-Progressive } \\
\text { Republican Party' } \\
\text { banned.. }\end{array}$ & $\begin{array}{l}\text { Sheikh } \\
\text { Said } \\
\text { Revolt } \\
\text { (Kurdish): } \\
\text { Nehri. } \\
\text { Hazo, } \\
\text { Haco. } \\
\text { Sason. } \\
\text { First Agri. } \\
\text { and } \\
\text { Kocusagi } \\
\text { revolts } \\
\text { (Kurdish). }\end{array}$ \\
\hline 1926 & & $\begin{array}{l}\text { Swiss Civil Code } \\
\text { adopted. }\end{array}$ & & \\
\hline 1927 & & $\begin{array}{l}\text { Abolition of the } \\
\text { 'Courts of Inde- } \\
\text { pendence'. }\end{array}$ & & $\begin{array}{l}\text { Mutki } \\
\text { Revolt } \\
\text { (Kurdish). }\end{array}$ \\
\hline $122^{\circ}$ & & $\begin{array}{l}\text { Reform of the } \\
\text { alphabet. }\end{array}$ & & \\
\hline
\end{tabular}




\begin{tabular}{|c|c|c|c|c|}
\hline & $\begin{array}{l}\text { International } \\
\text { Events }\end{array}$ & $\begin{array}{l}\text { Ottoman and } \\
\text { Turkish State }\end{array}$ & $\begin{array}{c}\text { Political Parties } \\
\text { and } \\
\text { Organizations }\end{array}$ & $\begin{array}{l}\text { Etnic and } \\
\text { Minority } \\
\text { Resistance }\end{array}$ \\
\hline 1930 & & $\begin{array}{l}\text { Exchange of popu- } \\
\text { lations between } \\
\text { Turkey and } \\
\text { Greece. }\end{array}$ & $\begin{array}{l}\text { Establishment of } \\
\text { the 'Free Party'. } \\
\text { 'Free Party' dis- } \\
\text { solved itself. }\end{array}$ & $\begin{array}{l}\text { Agri } \\
\text { Revolt } \\
\text { (1929- } \\
\text { 1930) (Kur- } \\
\text { dish); Men- } \\
\text { emen } \\
\text { Revolt } \\
\text { (reli- } \\
\text { giously } \\
\text { inspired). }\end{array}$ \\
\hline 1931 & & & $\begin{array}{l}\text { Establishment of } \\
\text { the 'Turkish His- } \\
\text { tory Society'. }\end{array}$ & \\
\hline 1932 & & & $\begin{array}{l}\text { Establishment of } \\
\text { the 'Turkish Lan- } \\
\text { guage Society'. }\end{array}$ & \\
\hline $\begin{array}{l}1937 . \\
1938\end{array}$ & & & & $\begin{array}{l}\text { Dersim } \\
\text { Revolt } \\
\text { (Kurdish). }\end{array}$ \\
\hline
\end{tabular}




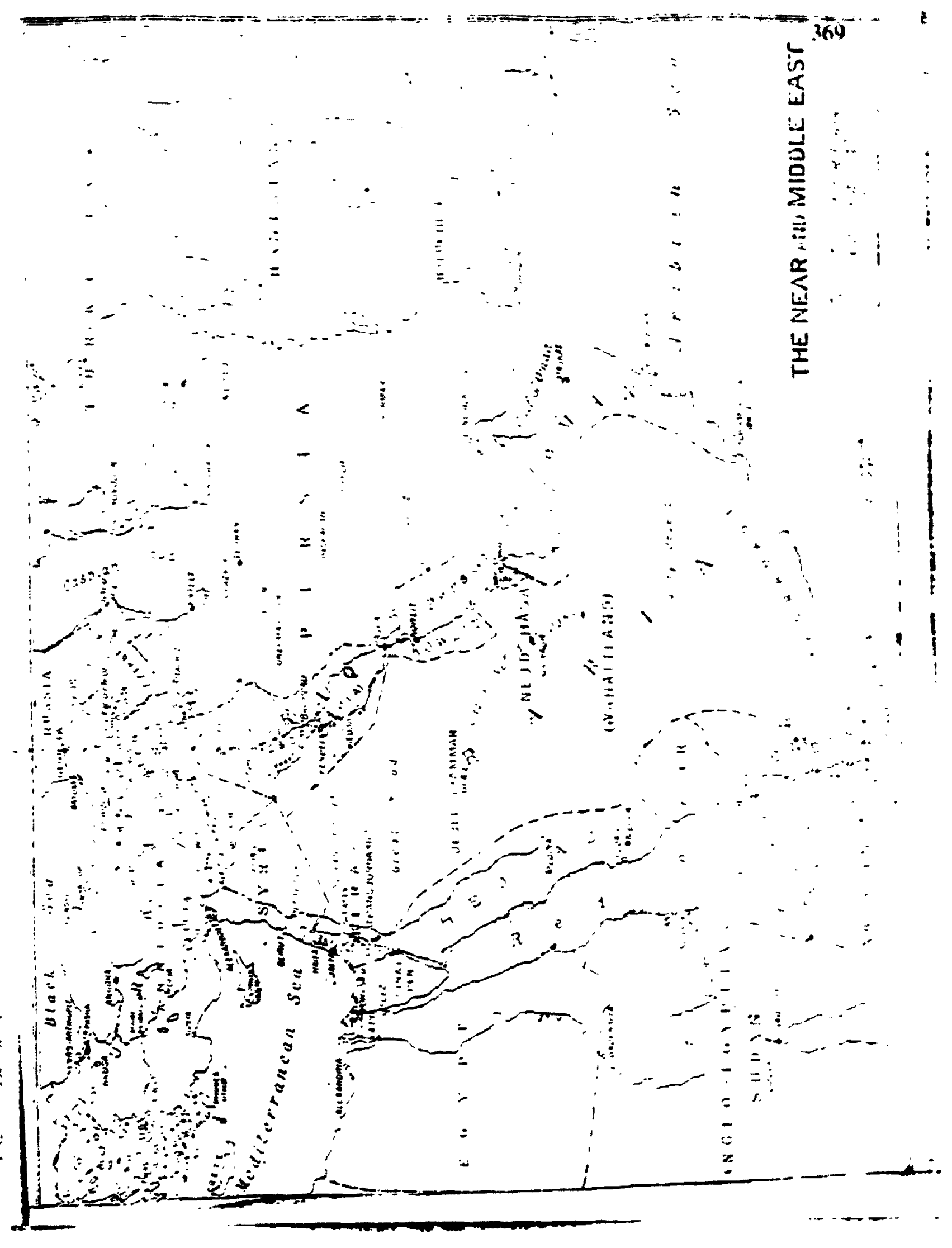








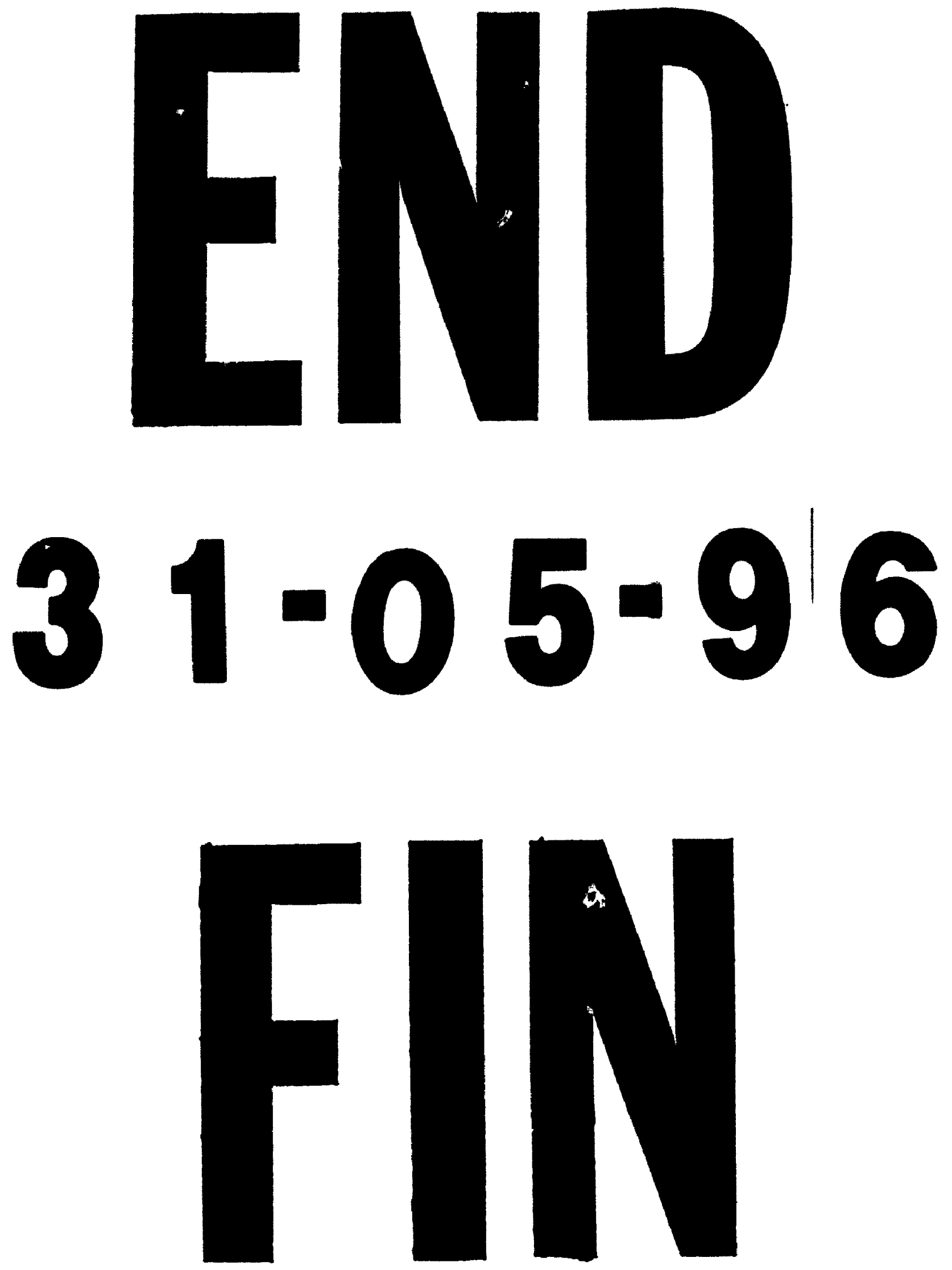